\title{
PALEOENVIRONMENTAL ANALYSIS OF THE HAUTAWA SHELLBED, WHANGANUI BASIN
}

\author{
Joanna Eveline Grace Elliott
}

A thesis submitted to Victoria University of Wellington in partial fulfilment of requirements for the degree of

Master of Science in Geology

School of Geography, Environment and Earth Sciences Victoria University of Wellington

October 2018 


\section{ABSTRACT}

The Hautawa Shellbed, Whanganui Basin is described in detail to uncover lateral variations in depositional paleoenvironment. This was achieved through the in situ documentation of the macrofaunal assemblage and its taphonomic attributes at three localities. The sites from west to east are: Ridge Road, Old Hautawa Road, and the type section on West Road. They are all exposures on farm tracks and cover a 20-km range across the central Whanganui Basin. The descriptions were collected at $15-\mathrm{cm}$ intervals and analysed using k-means clustering and Principal Component Analysis (PCA) to uncover trends within the data set. Combining the assemblage data with the taphonomic has allowed six major biofacies to be recognised. In turn, the arrangement of the biofacies in the sections suggest three subunits: A, B, and C. Subunits $A$ and $C$ are laterally continuous between all of the sections and always relate to the lowermost and uppermost portions of the Hautawa Shellbed. In contrast, subunit B is only observed to occur at West Road overlying subunit $A$. These subunits have can also be equated to sequence stratigraphic terminology. Subunits $A$ and $B$ form an onlap shellbed and subunit $C$ a backlap shellbed. Hence, the Hautawa Shellbed represents deposition during the transgressive systems tract of a single cyclothem. This study is unique compared to other Whanganui Basin stratigraphic research in its statistically robust approach for comparing data gathered at various sites along outcrop strike to better understand the preserved paleoenvironment.

To support the macro-faunal investigation, census counts of foraminifera were conducted for samples collected from the fine-grained sediments encompassing the Hautawa Shellbed at each of the three sites. Together, the macrofaunal and foraminiferal studies reveal temporal and spatial paleoenvironmental changes within the Hautawa Shellbed. The presence of biostratigraphically important fauna within the Hautawa Shellbed has been used to link the unit to other similar formations in both the Whanganui and East Coast Basins. This key assemblage which highlights the Nukumaruan-Mangapanian Stage boundary at 2.40 Ma includes: Zygochlamys delicatula, Crassostrea ingens, Phialopecten thomsoni, Phialopecten triphooki, and Mesopeplum convexum. The paleoenvironmental variations observed and presented here for the 
Hautawa Shellbed have been combined with published work on other parallel formations to produce a paleogeographic map of the Whanganui Basin for $2.40 \mathrm{Ma}$. 


\section{ACKNOWLEDGEMENTS}

Firstly, I want to thank my supervisors Mike Hannah and James Crampton for their guidance throughout this project.

A big thank you goes to my family for their unending encouragement of my studies and especially to my husband Alistair for his support and also developing a passion for rocks.

Thank you to all the friendly and supportive staff of Victoria University and GNS Science who provided advice and inspiration for this project. In particular: Cliff Atkins, Tim Naish, Kyle Bland, Katie Collins, Alan Beu, and Jane Chewings. Thanks also to my office mates in CO421 for both our quiet times and good yarns.

A special thank you to the land owners who made this work possible by permitting us to work on their land: Charlie \& Jo Duncan at Otiwhiti Station; John \& Alex Platts, and Steph \& Jordan at Colenso Station; and Andy \& Brenda Collins at Matawhitia Station.

Thank you all, again. 


\section{CONTENTS}

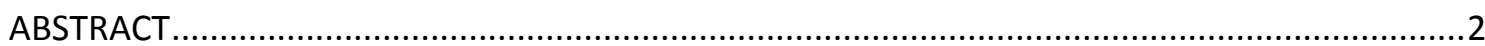

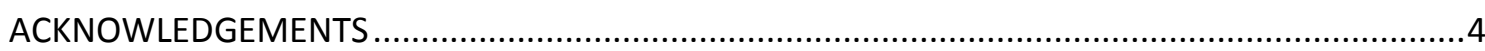

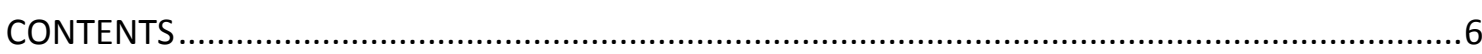

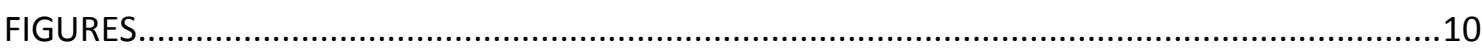

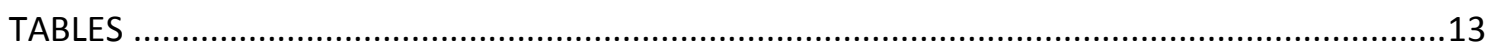

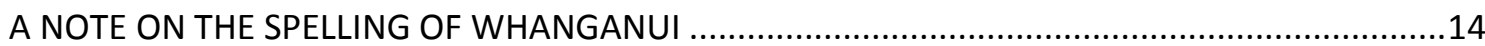

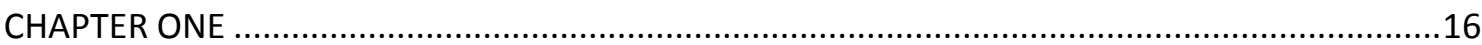

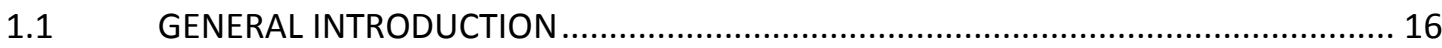

1.1.1 Thesis structure ............................................................................ 17

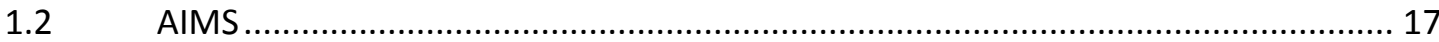

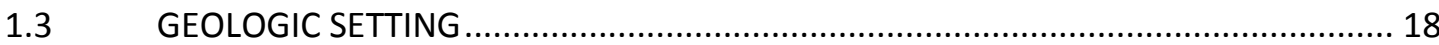

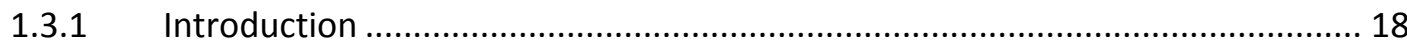

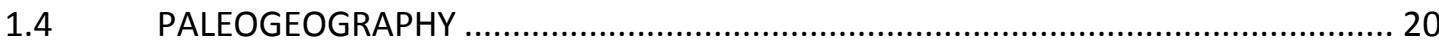

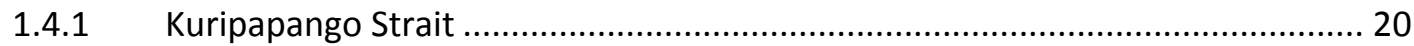

1.4.2 Manawatu Strait ........................................................................... 22

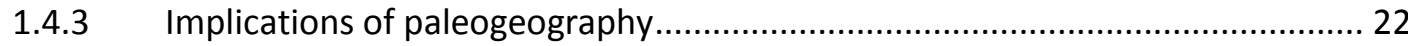

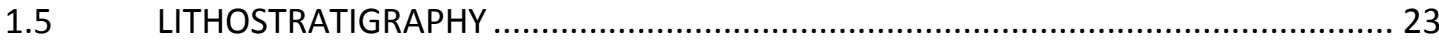

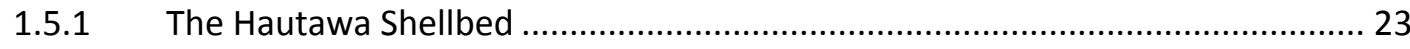

1.5.2 Western Whanganui Basin (Mclntyre \& Kamp, 1998) ................................... 23

1.5.3 Eastern Whanganui Basin (Naish \& Kamp, 1995) ........................................ 25

1.5.4 Summary stratigraphy Whanganui Basin................................................ 25

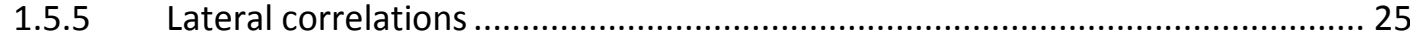

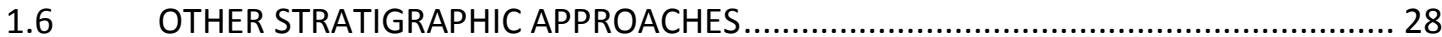

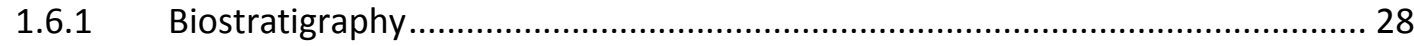

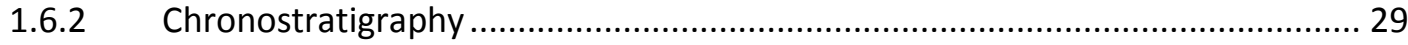

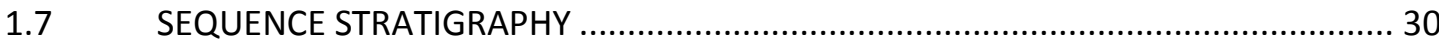

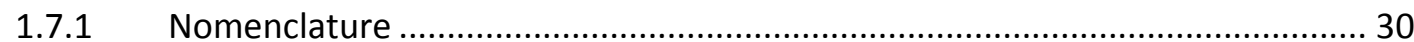

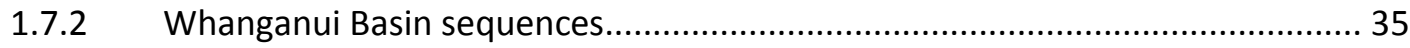

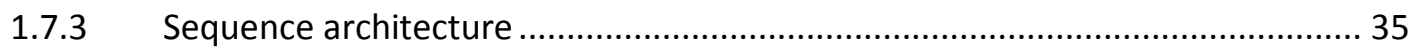

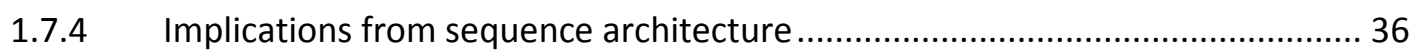

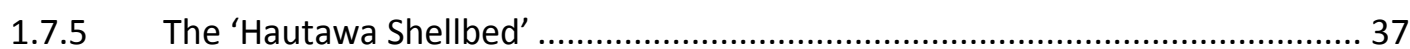




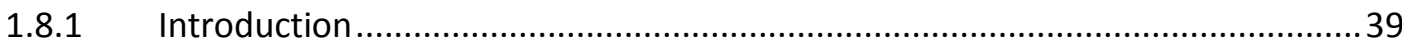

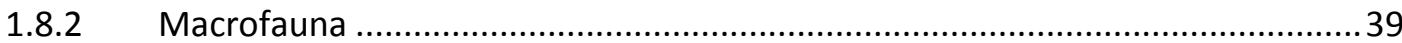

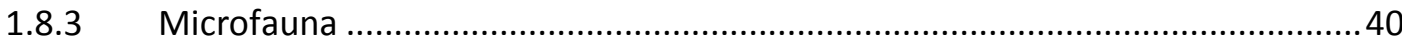

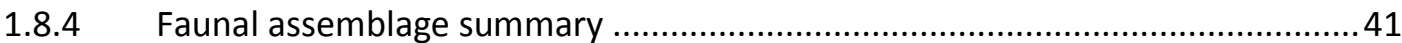

CHAPTER TWO

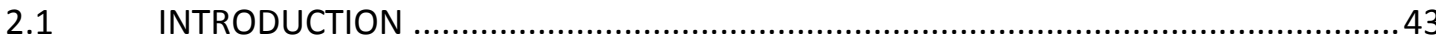

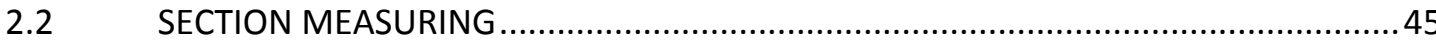

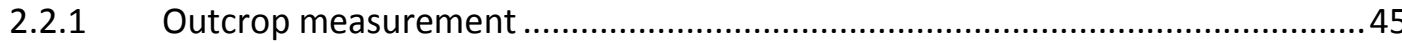

2.2.2 Sampling of macro-fauna .............................................................................. 49

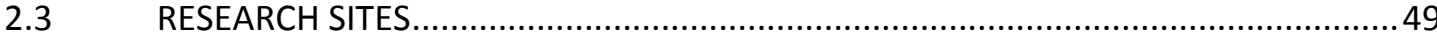

2.3.1 Central Whanganui Basin - Hautawa Shellbed ….............................................49

2.3.2 Eastern Margin - Limestones proximal to Ruahine Range...................................56

CHAPTER THREE

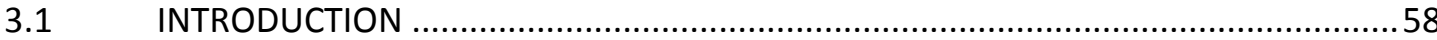

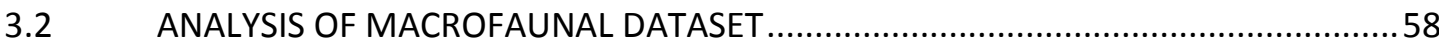

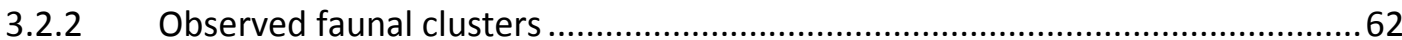

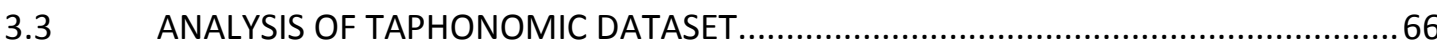

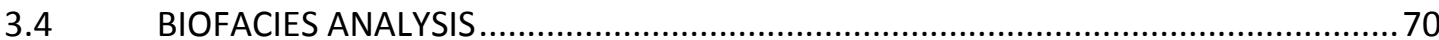

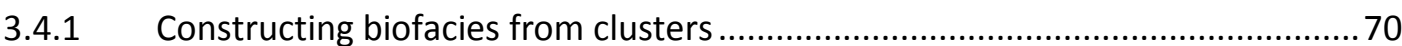

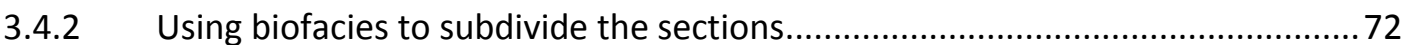

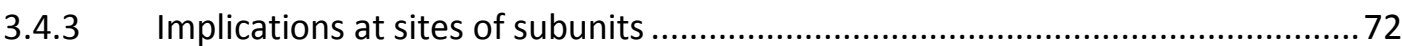

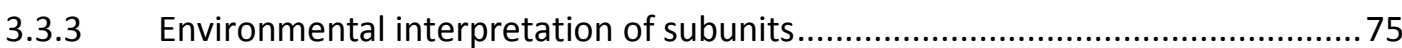

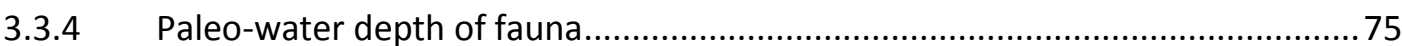

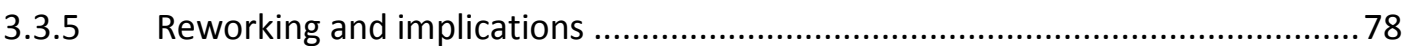

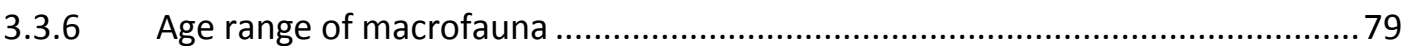

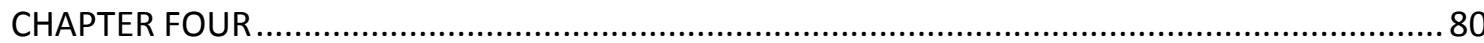

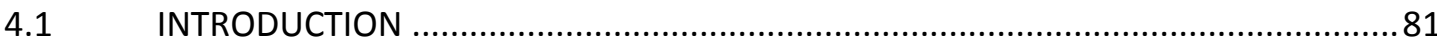

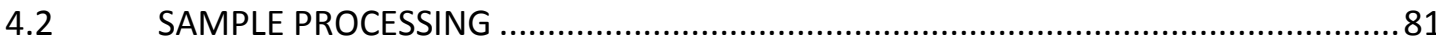

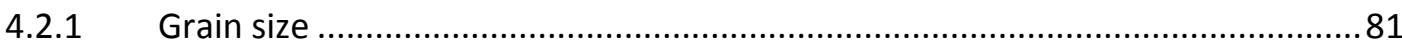

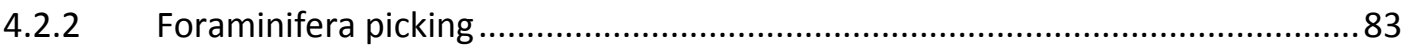

CHAPTER FIVE 
CONTENTS

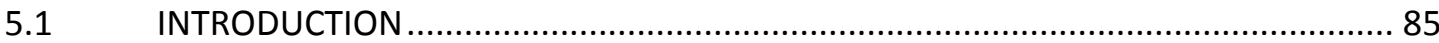

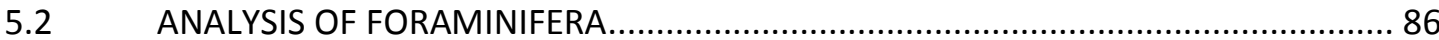

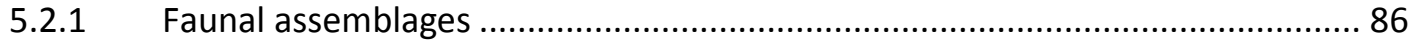

5.2.2 Proxies and methods for paleo-water depth .................................................. 92

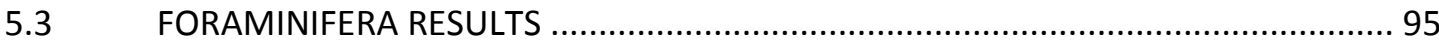

5.3.1 Paleo-water depth at central basin sites ....................................................... 95

5.3.2 Paleo-water depth at eastern margin site ...................................................... 96

5.3.3 Age range from microfaunal assemblage ........................................................ 96 99

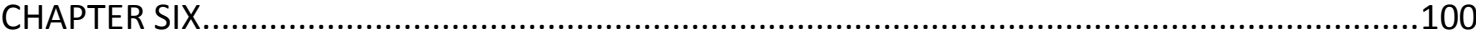

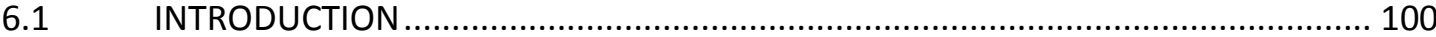

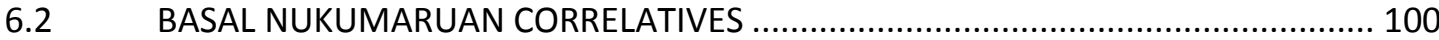

6.2.1 Central Basin Hautawa Shellbed ............................................................... 100

6.2.2 Colenso Station, east of Taihape................................................................ 108

6.2.3 Table Flat Shell Conglomerate; Cone Creek, east of Apiti ............................... 110

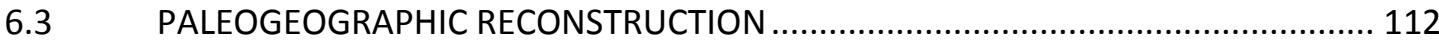

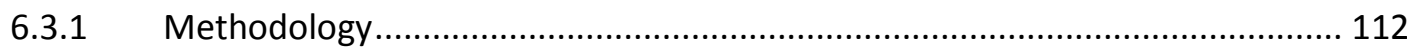

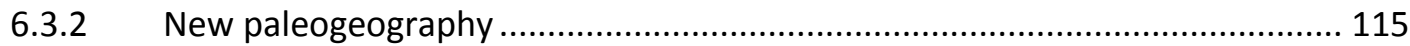

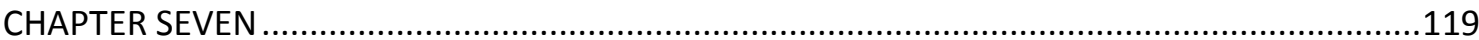

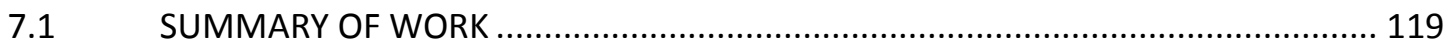

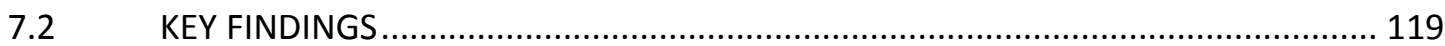

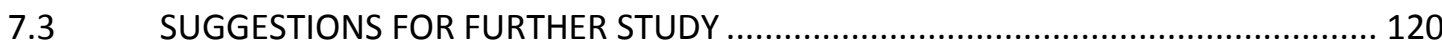

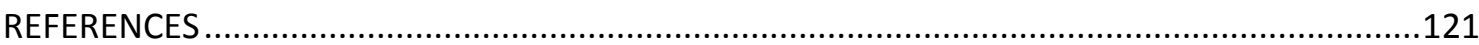

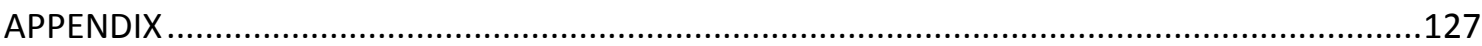

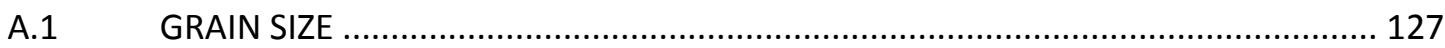

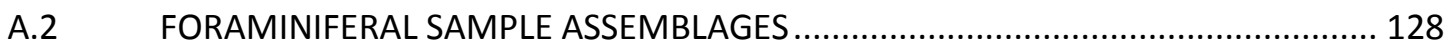

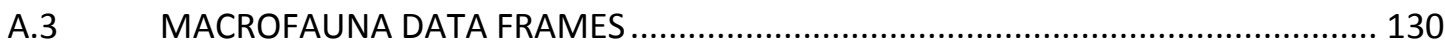

A.3.1 Faunal Assemblage .......................................................................... 130

A.3.2 Taphonomy ......................................................................................... 132

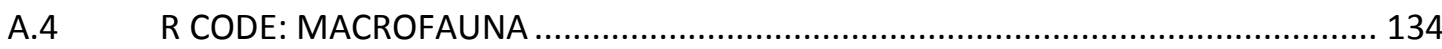

A.4.1 Code used in R to analyse macrofaunal assemblages ......................................... 134 
CONTENTS

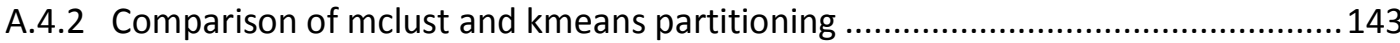

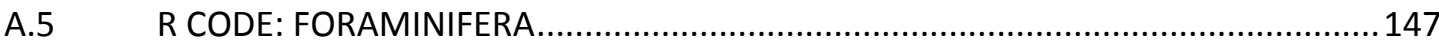

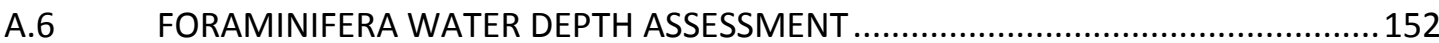

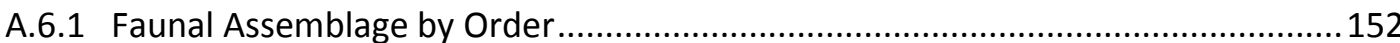

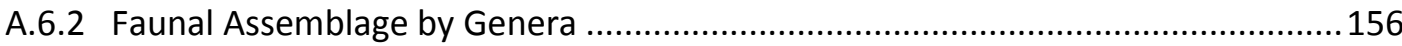

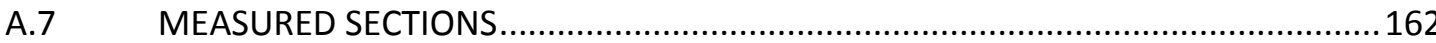




\section{FIGURES}

Figure 1.3.1: Tectonic plate boundary through New Zealand and the Zealandia continent.

Figure 1.4.1: Land mass and ocean current interactions for the Late Pliocene from Nelson et al. (2000). Sub-Antarctic fossil localities from A. Beu, Grant-Taylor, and Hornibrook (1977) shown by stars.

Figure 1.4.2: Simplistic paleogeography for central New Zealand at the Early Pleistocene, from Trewick and Bland (2012). Inferred to be representing a glacial lowstand with the Kuripapango Strait depicted closed.

Figure 1.4.3: Detailed paleogeography for the Hawke's Bay at the base of the Nukumaruan, from Kamp, Bland \& Nelson (2008). Kuripapango Strait is depicted open during this representative interglacial highstand.

Figure 1.5.1: Schematic cross-section linking key horizons from Whanganui Basin to East Coast Basin, as included in 'Geology of the Hawke's Bay Area' (Lee, et al., 2011) published as Map 8 in GNS Science' QMAP series

Figure 1.7.1: Stratal terminations and terminology from Catuneanu (2002)

Figure 1.7.2: Facies stacking due to transgressive and regressive sea level changes from Catuneanu (2002).

Figure 1.7.3: Systems tracts and their bounding surfaces relative to sea level change. Time passes left to right. Key in box applies to Figures 1.7.3 to 1.7.6.

Figure 1.7.4: Transgressive systems tract (TST) schematic. Shoreline to the left, and basin to the right. Upper shows systems tract. Lower shows shellbed deposits.

Figure 1.7.5: Highstand systems tract (HST) schematic. Shoreline to the left, and basin to the right. Upper shows systems tract. Lower shows shellbed deposits. 34

Figure 1.7.6: Regressive systems tract (HST) schematic. Shoreline to the left, and basin to the right. Upper shows systems tract. Lower shows shellbed deposits. 35

Figure 1.7.7: Symmetric Turakina motif compared to asymmetric Rangitikei motif. ....36

Figure 2.1.1: Structure of Chapter 2 and Chapter 3.

Figure 2.1.2: Comparison of exposure qualities present at West Road

Figure 2.2.1: Flow diagram of field approach to compile quantitative biostratigraphic data of taphonomy alongside traditional stratigraphic.

Figure 2.2.2: Taphonomic description of basal Hautawa Shellbed at Ridge Road; Mangamahu. JEGE_14A.

Figure 2.3.1: Map of localities studied. Coordinates of sites in Table 2.3.2. 
Figure 2.3.2: Photo of Ridge Road main site on Matawhitia Station. Scale $=1.5 \mathrm{~m} \ldots . . .53$

Figure 2.3.3: Photo of Old Hautawa Road site on Otiwhiti Station. Scale $=1.5 \mathrm{~m} \ldots \ldots \ldots . . .53$

Figure 2.3.4: Topographic map of West Road locations........................................... 55

Figure 2.3.5: Photo of West Road site during measuring of section $A$ at site JEGE_14. Scale $=1.5 \mathrm{~m}$ .56

Figure 3.2.1: Plot produced by cascadeKM in order to exhibit how the local maximum ssi criterion is reached when four clusters are found within the faunal dataset.

Figure 3.2.2: Plot of PC1 and PC2 with all four clusters shown. $40.3 \%$ of the variation in the faunal dataset is accounted for by these axes.

Figure 3.2.3: Plot of PC1 and PC3 with all four clusters shown. $37.2 \%$ of the variation in the faunal dataset is accounted for by these axes.

Figure 3.2.4: Plot of PC2 and PC3 with all four clusters shown. $24.9 \%$ of the variation in the faunal dataset is accounted for by these axes.

Figure 3.2.5: Bi-plot of complete faunal dataset showing clusters, samples (points), and genera (the variable vectors).

Figure 3.3.1: Plot produced by cascadeKM in order to exhibit how the local maximum ssi criterion is reached when three clusters are found within the taphonomic dataset.

Figure 3.4.1: Illustration of biofacies and subunits displayed on measured section B at West Road. Full section included in the Enclosure.

Figure 3.4.2: Faunal biofacies observed and subunits compared between central basin sites.

Figure 3.4.3: Water depth range chart for macrofauna in Subunit $A=$ range of 5 to 40 m.

Figure 3.4.4: Water depth range chart for macrofauna in Subunit $B=$ range of 20 to 40 m.

Figure 3.4.5: Water depth range chart for macrofauna in Subunit $C=$ range of 20 to 45 m.

Figure 3.4.6: Age range chart of key molluscs observed in the Hautawa Shellbed compared to both the New Zealand Geologic Timescale and species age ranges in millions of years. .80

Figure 4.2.1: Structure of Chapter 4 and Chapter 5.

Figure 4.2.2: Plot of relationship between $\%$ mud and depositional water depth on a wave graded shelf, Figure 10 from Dunbar \& Barrett (2005). Based on data collected off the modern Manawatu coast and is fitted with a $4^{\text {th }}$ order polynomial. 
Figure 4.2.3: Flow diagram of sample processing to produce foraminifera picking appropriate dry fractions - primarily from 63-500 $\mu \mathrm{m}$.

Figure 5.1.1: Summary of paleodepth and oceanicity based on New Zealand Neogene foraminiferal faunal assemblages (based on Figure 89; Hayward, 2010). Expected ranges for planktic percentage observed is given below each sub-region title.

Figure 5.2.1: Plot produced by cascadeKM in order to exhibit how the maximum ssi criterion is reached when three clusters are found within the foraminifera dataset.... 88

Figure 5.2.2: Biplot produced for samples distributed based on foraminiferal assemblages.

Figure 5.2.3: Juvenile brachiopods from sample 001, intra-shellbed siltstone on Old Hautawa Road, Otiwhiti Station. Viewed with light microscope.

Figure 5.2.4: Correlation between sites using foraminiferal clusters observed and sediment sample positions proximal to the Hautawa Shellbed in the central Whanganui Basin

Figure 5.3.1: Water depth changes observed relative to basal contact (m).

Figure 6.1 1: Map of key formations and their modern outcrop distribution. Data from GNS Science QMAP series. Locations of key sites plotted.

Figure 6.3.1: Zygochlamys delicatula with geologic hammer for scale. Located by JEGE in conglomeratic beds in Broadlands Stream. Identification validated in the field by $\mathrm{Dr}$ Katie Collins.

Figure 6.3.2: Central New Zealand paleogeographic reconstruction of earliest Nukumaruan Stage. Key on opposing page.

Figure 6.3.3: Abundant greywacke pebbles present in both Sentry Box Formation [upper photo, sourced from Lee et al. (2011)] and Table Flat Shell Conglomerate [lower photo]

Figure A.4.1: Bi-plot of mclust partitioning of faunal assemblage dataset into six clusters. Clusters 2 and 3 shown here.

Figure A.4.2: Bi-plot of mclust partitioning of faunal assemblage dataset into six cluster. Clusters 1, 4, 5, and 6 shown here....

Figure A.4.3: Bi-plot of kmeans partitioning of faunal assemblage dataset into six cluster. Clusters 1 and 2 shown here.

Figure A.4.4: Bi-plot of kmeans partitioning of faunal assemblage dataset into six cluster. Clusters 2 and 4 shown here.... 


\section{TABLES}

Table 1.5.2: Lithostratigraphic scheme in western Whanganui Basin after Mclntyre and Kamp (1998) 24

Table 1.5.2: Lithostratigraphic scheme in eastern Whanganui Basin after Naish et al. (1995). 24

Table 1.5.3: Modern stratigraphy of the Whanganui Basin at the MangapanianNukumaruan boundary. Formation names are left justified and named members right justified. 26

Table 1.6.1: Bioevent markers situated in the Hautawa Shellbed, adapted from Table 7.1 McIntyre (2002) pg. 233. .28

Table 1.7.1: Abbreviations common to sequence stratigraphy. 30

Table 1.7.2: Summary of sequence stratigraphic terminology regarding shellbeds and their applications based on descriptions in Kondo et al. (1998). 38

Table 2.2.1: Taphonomic attribute classification scheme after Hendy, Kamp, and Vonk (2006).

Table 2.2.2: Exemplary field notes for basal Hautawa Shellbed at Ridge Road; Mangamahu. 48

Table 3.4.1: Biofacies scheme for Hautawa Shellbed built on cluster analysis of faunal and taphonomic datasets. .71

Table 5.2.1: Percentages of common key foraminifera identified in samples. Bold text emphasising relative higher percentage values. Samples are grouped based on trends in observed during picking.

Table 5.2.2: Results for water depth from various sources and proxies for sample 001.

Table 5.2.3: Water depths in meters from all proxies measured in all samples...........95

Table 6.2.1: Stratigraphic artitecture and sequence motif observed at key sites........104

Table 6.3.1: Chart of key fauna known to be present in formations and the age range inferred.....

Table A.4.1: Comparison of mclust and kmeans partitioning and the breakdown of number of points placed into each cluster out of the total 51 points. 144

Table A.7.1: Summary of measured sections in enclosures. 162

Table A.7.2: Summary of facies abbreviations used in measured sections 162 


\section{A NOTE ON THE SPELLING OF WHANGANUI}

The spelling of some Māori place names and geographic features have changed over the years. In particular, the spelling of 'Whanganui' or 'Wanganui' is applicable to this thesis. The spelling without an ' $h$ ' is prevalent in the geologic literature for the region. The New Zealand Geologic Timescale 2015/1 also refers to the youngest New Zealand Series as 'Wanganui'.

As of 2012, either spelling is regarded as correct for the township as determined by the Minister for Land Information. The Māori Language Commission supported the correction to 'Whanganui' as the name is a compound word of 'whanga' (harbour) and 'nui' (big). To lack the ' $h$ ' produces a word not in the Māori lexicon. The river itself is formally considered to be 'Whanganui River' by LINZ and included as such in the Topo50 map series.

In this thesis 'Whanganui' is therefore used in all cases, even when referring to literature which use the prior spelling. 


\section{CHAPTER ONE \\ INTRODUCTION}

\subsection{GENERAL INTRODUCTION}

Whanganui Basin, on the west coast of New Zealand, contains a $4 \mathrm{~km}$ thick sedimentary sequence of Pliocene-Pleistocene age mostly shallow marine strata (Naish, 2005). The cyclic glacio-eustatic sea level fluctuations of the Pliocene-Pleistocene are preserved in this far field evidence of recorded environment changes (McIntyre \& Kamp, 1998). Robust cyclostratigraphic correlation with marine isotope stages through tephrochronology, sequence stratigraphy, and biostratigraphy has made Whanganui Basin into one of the locations in the world to study shallow marine records of past sea level and climatic changes (Carter \& Naish, 1998; Naish et al., 1998). Hence, the records preserved in the Whanganui Basin have featured in numerable publications on a range of topics including: past global climate and the magnitude of sea level fluctuations, volcanic activity in the Taupo Volcanic Zone, and many others (Naish et al., 1995; Pillans, Chappell, \& Naish, 1998; Sefton, 2015).

Since the mid-twentieth century, researchers such as Charles Fleming have known that the arrival of the extant sub-Antarctic scallop Zygochlamys delicatula into the Whanganui Basin in the Hautawa Shellbed heralded a significant shift to a cooler paleoclimate (Fleming, 1944, 1953). Warmer fauna (e.g. Crassostrea ingens and Phialopecten thomsoni) went extinct from the New Zealand region at the base of this shellbed. This change in faunal assemblage signifies the Mangapanian to Nukumaruan Stage boundary in the New Zealand Geologic Timescale. This boundary marks a significant point in time - the onset of Quaternary climate as expressed in the New Zealand geologic record. This change in global systems and climate is of significant interest in consideration of the modern rapid climate variability experienced today.

Recent discovery of outcrops along the far eastern edge of the Basin against the Ruahine Range containing Zygochlamys delicatula has inspired further research into the Hautawa Shellbed (J. Lee, Bland, Townsend, \& Kamp, 2011). The Hautawa Shellbed outcrops for ca. $50 \mathrm{~km}$ across the basin from the Whanganui to the Rangitikei River, and it 
provides an ideal unit to investigate for the reconstruction of lateral paleoenvironmental variations. High resolution paleoenvironmental investigation of the Hautawa Shellbed then provides useful evidence for the construction of a basal Nukumaruan paleogeographic map for the Whanganui Basin.

\subsubsection{Thesis structure}

- $\quad$ Chapter One contains details regarding the background setting for this research including: the geologic setting, litho- and chrono-stratigraphic framework, a review of sequence stratigraphic theory and nomenclature, and key paleontological information.

- $\quad$ Chapter Two introduces the macro-paleontological methods applied and Chapter Three discusses the results and analyses from the macro-faunal dataset.

- $\quad$ Chapter Four presents the methods applied relating to micro-paleontology and Chapter Five describes the results and analyses of the micro-faunal dataset.

- $\quad$ Chapter Six integrates macro- and micro-paleontological dataset results and discusses their significance and application.

- $\quad$ Chapter Seven presents a summary of this thesis, key findings, and suggestions for further study.

\subsection{AIMS}

This thesis aims to investigate the varying paleoenvironments recorded in the Hautawa Shellbed as observed at locations across the Whanganui Basin.

This has been achieved through:

- Investigation of the stratigraphic and paleontological composition of the Hautawa Shellbed.

- Determination of whether newly-discovered outcrops at Colenso Station, east of Taihape, are correlatives of the Hautawa Shellbed.

- $\quad$ Expand knowledge of paleoenvironments of the Whanganui Basin proximal to the paleo-coastline at the time of the Mangapanian-Nukumaruan stage boundary. 


\section{CHAPTER ONE}

- $\quad$ Production of a paleo-geographic reconstruction of the Whanganui Basin for the Mangapanian-Nukumaruan stage boundary.

\subsection{GEOLOGIC SETTING}

\subsubsection{Introduction}

The Zealandia continent is situated across the plate boundary between the Aus-

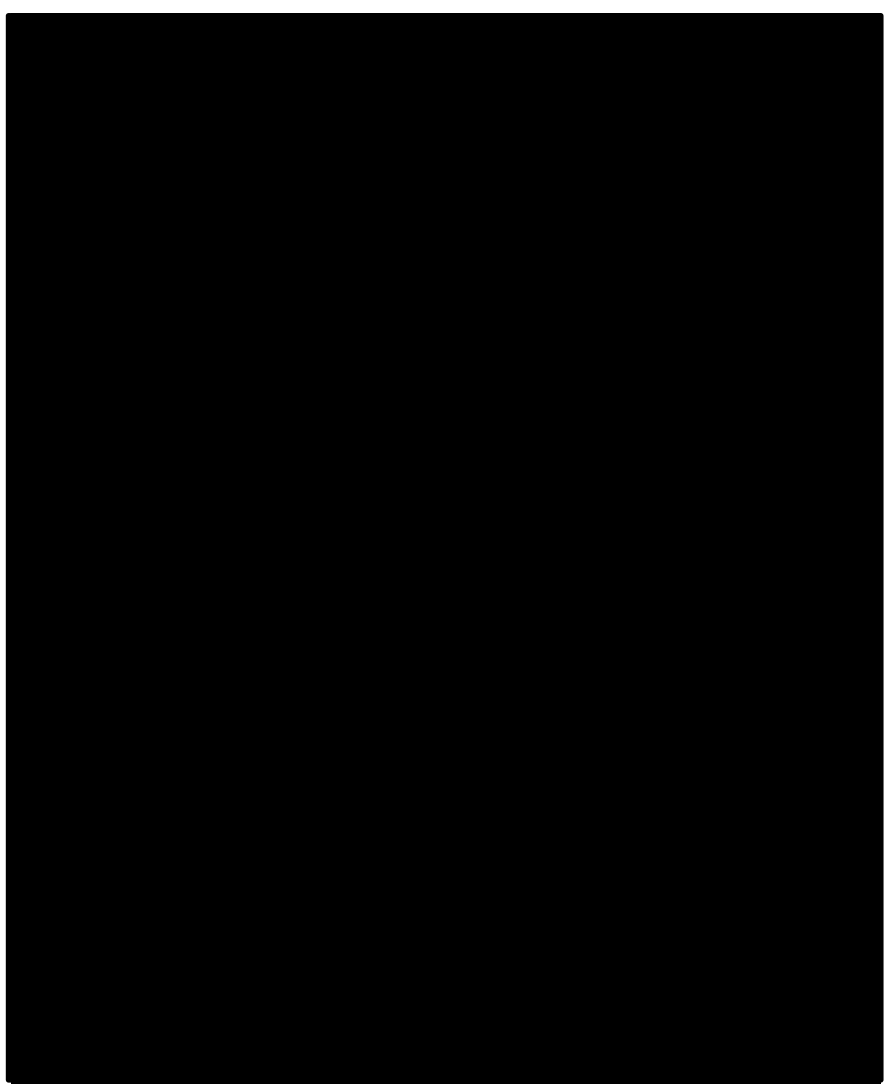

A) Map of plate boundary location soured from Te Ara website (www.teara.govt.nz). Zealandia continent shown by bathymetry which emphasises the continental vs oceanic crust.

B) Schematic map of New Zealand tectonic setting sourced from Naish and Kamp (1995)

C) West to east schematic cross-section of the plate tectonic setting of the southern central North Island, New Zealand after Naish and Kamp (1995). Equivalent to A-A' cross-section shown in $B$.

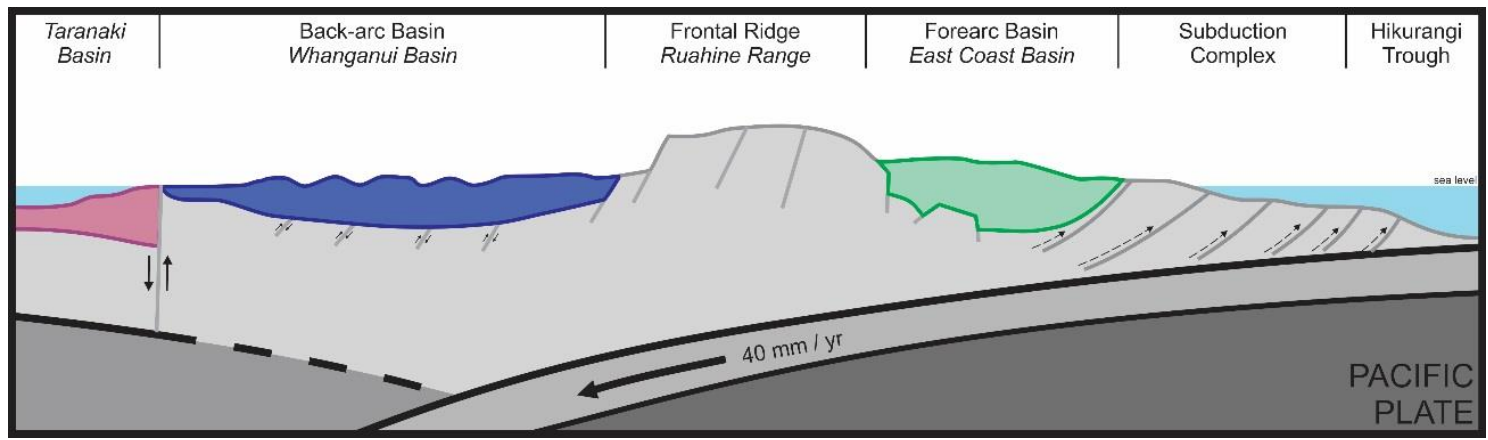

Figure 1.3.1: Tectonic plate boundary through New Zealand and the Zealandia continent. 
tralian (also called the Australasian) and Pacific Plates [Fig. 1.3.1 A, B]. Zealandia incorporates 4.9 million square kilometres of continental crust, but today $94 \%$ of it is submerged (Mortimer et al., 2017) [Fig. 1.3.1 A]. New Zealand makes up the majority of the emergent landmass of Zealandia which also includes New Caledonia in the north and the Auckland and Campbell Islands in the south (Mortimer et al., 2017). The northern portion of the plate boundary, north of the Alpine Fault, is the Hikurangi Subduction Zone: where the Pacific Plate is subducted beneath the Australasian Plate. Convergence between these two plates is currently at a rate of $40-\mathrm{mm}$ per year [Fig. 1.3.1 C].

The Whanganui Basin, on the west coast of the central North Island of New Zealand is a back-arc basin which has formed along the Hikurangi margin [Fig. 1.3.1 C]. Directly to the east of the Whanganui Basin is the frontal ridge of the North Island, the Ruahine Range, and to the west is the Taranaki Basin. The margins of the Whanganui Basin in simplest terms are defined by the Taranaki Boundary Fault to the west and the axial Ruahine Range to the east.

During the Pliocene and Pleistocene, coupling of the tectonic plates led to backarc pull down due to plate flexure (Davey \& Stern, 1990). Due to the balance between rates of sedimentary infill and basin subsidence, the eustatic sea level fluctuations of this time are preserved in a nearly continuous record of predominantly marine strata in the Whanganui Basin. The $4 \mathrm{~km}$ thick sequence is considered to be one of the world's best sedimentary records and hence is an ideal place to examine how climatic influences are expressed within the sedimentary record (Naish \& Kamp, 1995). Naish et al. (1998) found that the basin-fill is made up of 58 fifth and sixth-order shallow marine cycles. This forms a record of the past 3.6 million years, with 100,000- and 41,000-year Milankovitch-paced glacio-eustatic sea-level cycles preserved. The record is astronomically calibrated and tuned through an integrated chronology (Naish et al., 1998), with techniques such as biostratigraphy, tephrochronology, and magnetostratigraphy having been used extensively to correlate with the oxygen isotope curve (Naish et al., 1998). 


\subsection{PALEOGEOGRAPHY}

Since the Pliocene, the New Zealand landmass has been successively cut from west to east by a series of paleo-seaways or 'straits' [Fig. 1.4.1]. It is this series of seaways which linked the east and west coasts of the North Island, which allowed water to mix from the east to enter into the Whanganui Basin. The position of these straits has migrated southward and today are represented by the Cook Strait dividing the South and North Islands of New Zealand. Prior to this the Manawatu and Kuripapango Straits connected the Whanganui and East Coast Basins.

During the Pliocene, much of the central Wairarapa and Hawke's Bay were underwater in a narrow but laterally extensive marine region referred to as the Ruataniwha Strait [Fig. 1.4.2] (Trewick \& Bland, 2012). To the east the strait was constrained by the rising accretionary wedge which formed a chain of islands and marine shoals by the late Pliocene.

\subsubsection{Kuripapango Strait}

In the late Pliocene, the north eastern Whanganui Basin and East Coast Basins were joined by the Kuripapango Strait which was situated where modern day northern Ruahine and southern Kaimanawa-Kaweka Ranges are located (Browne, 2004a). This strait is named after the small settlement of Kuripapango on the TaihapeNapier Road. During the earliest Nukumaruan, it has been suggested that this strait was only open during interglacial highstands [Fig. 1.4.3] (Bland, Kamp, \& Nelson, 2008).

Figure 1.4.1: Land mass and ocean current interactions for the Late Pliocene from Nelson et al. (2000). Sub-Antarctic fossil localities from A. Beu, GrantTaylor, and Hornibrook (1977) shown by stars.

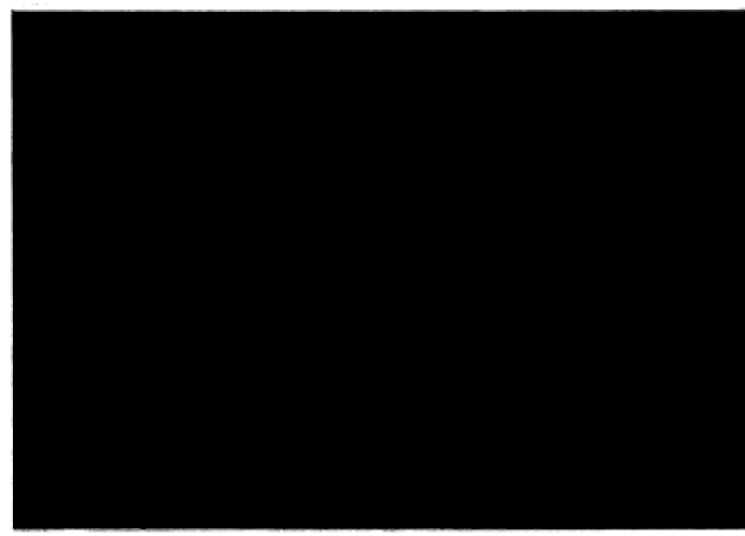


Figure 1.4.2: Simplistic paleogeography for central New Zealand at the Early Pleistocene, from Trewick and Bland (2012). Inferred to be representing a glacial lowstand with the Kuripapango Strait depicted closed.

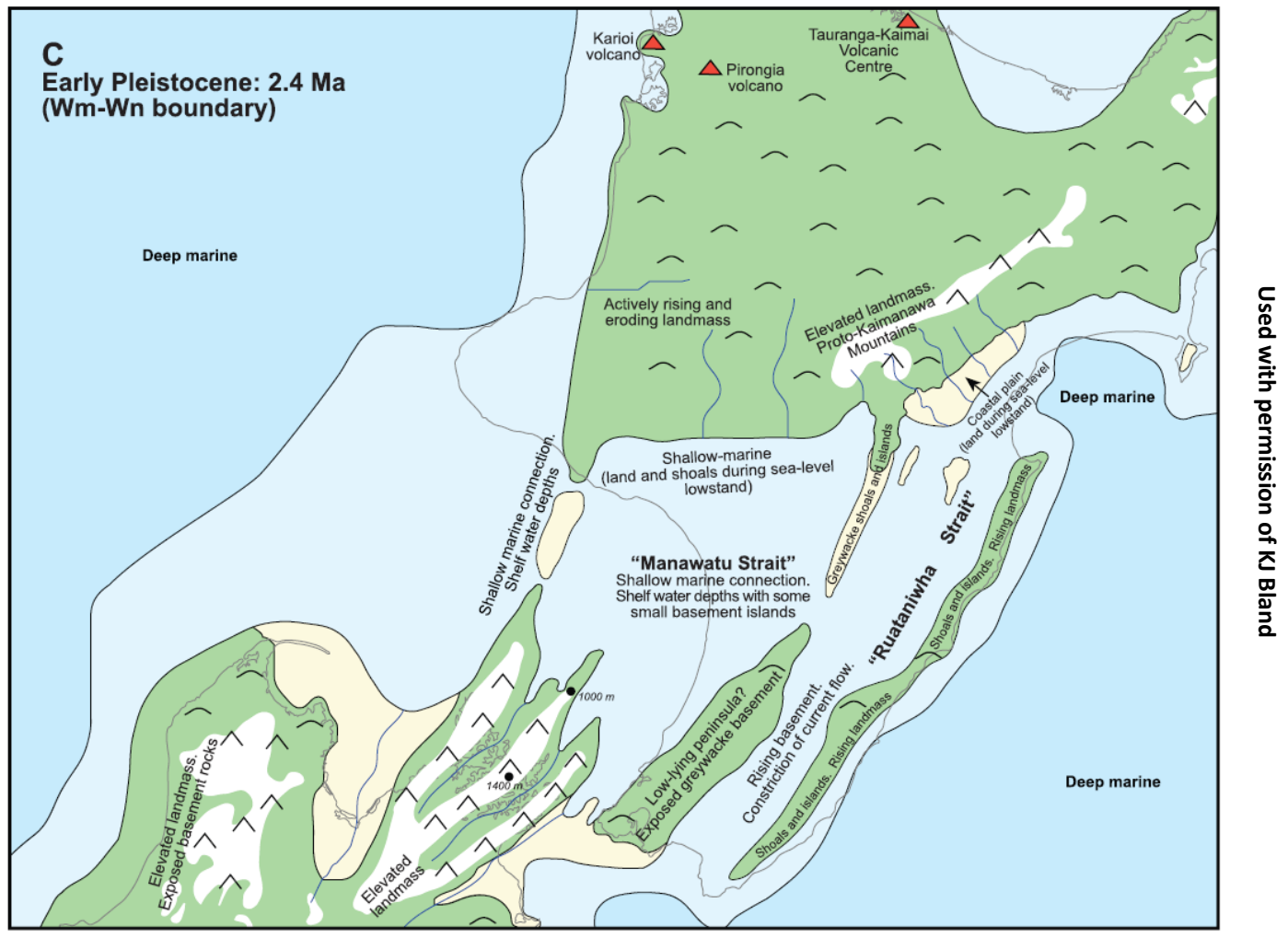

Figure 1.4.3: Detailed paleogeography for the Hawke's Bay at the base of the Nukumaruan, from Kamp, Bland \& Nelson (2008). Kuripapango Strait is depicted open during this representative interglacial highstand.

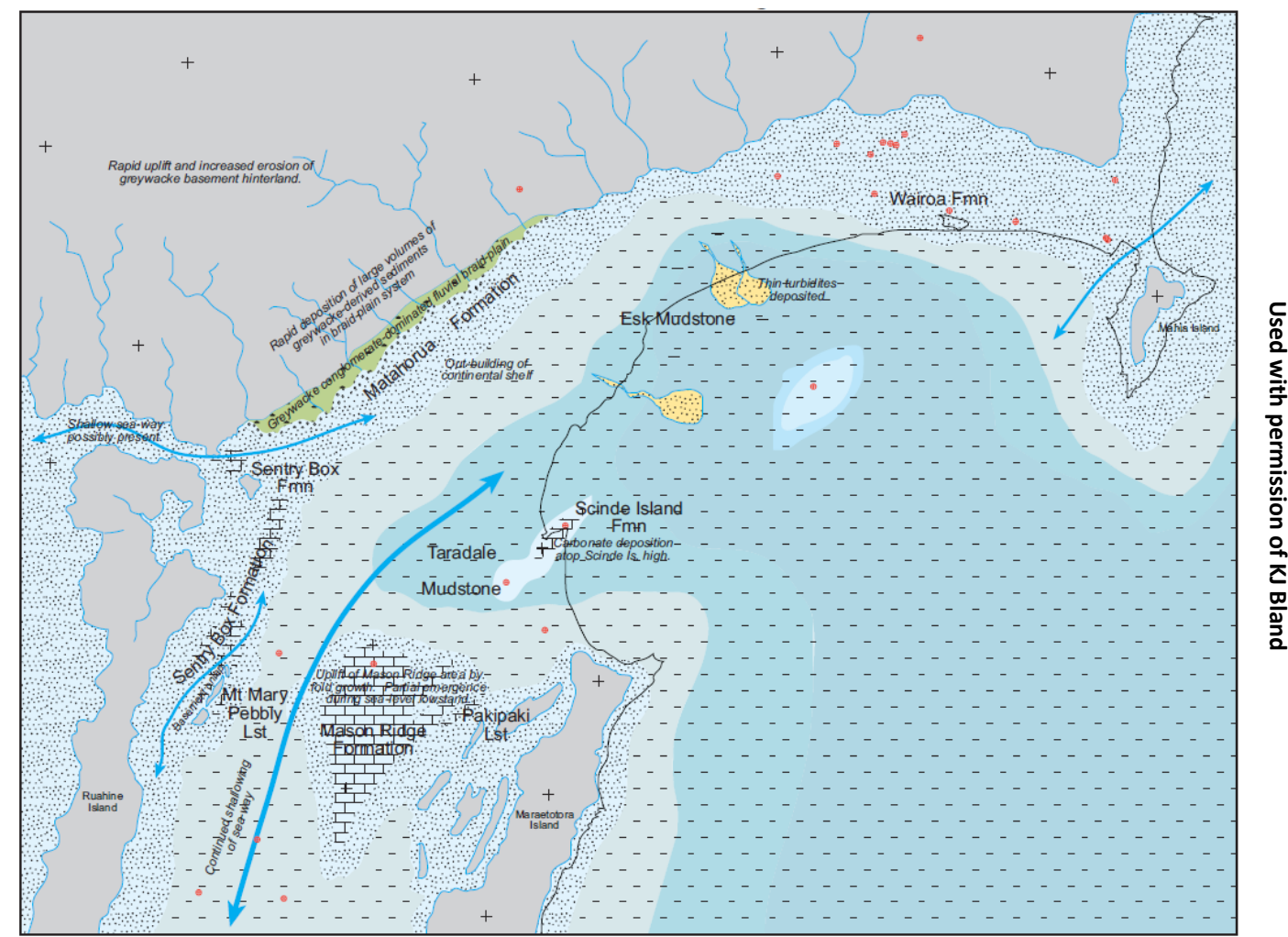




\subsubsection{Manawatu Strait}

The Manawatu Strait was positioned just north of the present-day Manawatu Gorge, in the region of the Manawatu Saddle. Recent work has shown that while the strait was narrow during the early Nukumaruan, it contained strong tidal currents along with mostly upper shelf water depths (Milner, 2017). The strait is thought to have then became more extensive during the middle and late Nukumaruan.

\subsubsection{Implications of paleogeography}

The immigration of cold water fauna to the latitude of the central North Island, New Zealand was documented as occurring during the early Nukumaruan Stage by Fleming (1944) [Fig. 1.4.1]. This event was synchronous with extinctions of warm water genera, such as the giant oyster Crassostrea ingens and Phialopecten thomsoni, in these areas. Fleming (1944) considered the scallop Zygochlamys delicatula to be the most characteristic cold-water mollusc of this cold-water faunal group which also contains Tawera subsulcata and Stiracolpus symmetricus. Zygochlamys delicatula is an extant, sub-Antarctic species, commonly referred to as the 'queen scallop'.

The Manawatu Strait has, for much of the past half-century, been thought of as the access route for southern ocean molluscan larvae into Whanganui Basin (A. Beu et al., 1977). Detailed work in 1998 by Orpin, Gammon, Naish, and Carter, investigated the significance of Zygochlamys delicatula in both ancient shellbeds and modern deposits. Orpin et al. (1998) argued that Zygochlamys delicatula represent times of waning glacial (colder-water) conditions in the Whanganui Basin, when the shelf was starved of terrigenous sediment due to rapid shoreline transgression. They also suggest that the restriction of Zygochlamys delicatula to only a few, early Nukumaruan cyclothems in the Rangitikei sequence is due to "an unfavourable combination of palaeo-hydrography, including depth, water temperature and turbidity" (pg. 276) (Orpin, Gammon, Naish, \& Carter, 1998). As the loss of Zygochlamys delicatula from the Whanganui Basin during the early Nukumaruan is likely not a result of Manawatu Strait complete closure as previously suggested, the lack of Zygochlamys delicatula in the higher cyclothems of the Whanganui Basin is more likely due to other unfavourable conditions not lack of possible access from south eastern New Zealand. 


\subsection{LITHOSTRATIGRAPHY}

\subsubsection{The Hautawa Shellbed}

Today in the Whanganui Basin, the lower boundary of the Nukumaruan Stage is thought to be indicated by the lowest occurrence in the basin of Zygochlamys delicatula at the base of the Hautawa Shellbed (A. Beu, 2001; R. Cooper \& Agterberg, 2004; Hollis et al., 2010; McIntyre, 2002). The Hautawa Shellbed was first described by Superior Oil Company as the 'Hautawa Reef Horizon' recognised along the south side of the Hautawa Stream valley (Feldmeyer, Jones, Firth, \& Knight, 1943). Known and previously studied outcrops of the Hautawa Shellbed extend over 50 kilometres from the Whanganui River Valley eastward to the Rangitikei Valley (Mclntyre, 2002).

The lithostratigraphy of the Whanganui Basin is understood better now than when originally described by Fleming (1953). Today the basin stratigraphy of this age is split into two different groups: the Okiwa Group in the west, and the Rangitikei Group in the east. Tables 1.5.1 and 1.5.2 show the historic correlations as compiled by Naish and Kamp (1995) and McIntyre and Kamp (1998); repsectively.

\subsubsection{Western Whanganui Basin (Mclntyre \& Kamp, 1998)}

Mclntyre \& Kamp (1998) formally describe seven formations within the Okiwa Group in the western segment of the Whanganui Basin. Of importance to this study, the Hautawa Shellbed is placed in the Whariki Formation in the western Whanganui Basin. This formation is made up of two members: a coquina member (the Hautawa Shellbed) and a siliciclastic sandstone member (the Upokonui Sandstone) (McIntyre \& Kamp, 1998). The Hautawa Shellbed was deposited during a period of progressive deepening, likely to middle shelf. While in contrast, the sharp base of the sandstone was interpreted as a rapid, regressive shallowing and the Upokonui has an inner-shelf to shoreface environment. 


\section{CHAPTER ONE}

Table 1.5.2: Lithostratigraphic scheme in western Whanganui Basin after Mclntyre and Kamp (1998).

\begin{tabular}{|c|c|c|c|c|c|c|c|}
\hline \multicolumn{3}{|c|}{ Fleming (1953) } & \multicolumn{3}{|r|}{ Ker (1973) } & \multicolumn{2}{|r|}{ Mclntyre and Kamp (1998) } \\
\hline \multirow{7}{*}{ 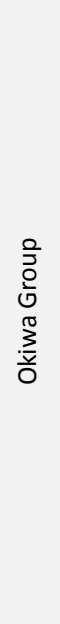 } & \multirow{3}{*}{$\begin{array}{l}\frac{1}{0} \\
\stackrel{0}{2}\end{array}$} & \multirow{3}{*}{$\begin{array}{l}\text { Undifferentiated } \\
\text { Upokonui Sand } \\
\text { Hautawa Shellbed }\end{array}$} & \multirow{7}{*}{ 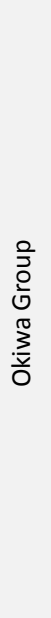 } & \multirow{3}{*}{ 衣 } & \multirow{3}{*}{ Hautawa Shellbed } & \multirow{8}{*}{$\begin{array}{l}\frac{0}{3} \\
0 \\
\frac{0}{0} \\
\frac{\pi}{2} \\
\frac{\pi}{0}\end{array}$} & Wickham Formation \\
\hline & & & & & & & Shaw Formation \\
\hline & & & & & & & $\begin{array}{l}\text { Upokonui Sandstone } \\
\text { Whariki Formation } \\
\text { Hautawa Shellbed }\end{array}$ \\
\hline & \multirow{4}{*}{$\sum_{0}^{\bar{N}}$} & \multirow{4}{*}{$\begin{array}{l}\text { Parihauhau Shellbed } \\
\text { Te Rimu Sand }\end{array}$} & & \multirow{4}{*}{$\sum_{0}^{\grave{\Phi}}$} & \multirow{4}{*}{$\begin{array}{l}\text { Te Rama Shellbed } \\
\text { Undifferentiated } \\
\text { Parihauhau Shellbed } \\
\text { Te Rimu Sand }\end{array}$} & & $\begin{array}{l}\text { Parikino Formation } \\
\text { Caseley Conglomerate }\end{array}$ \\
\hline & & & & & & & $\begin{array}{l}\text { Tirotiro Formation } \\
\qquad \text { Parihauhau Shellbed }\end{array}$ \\
\hline & & & & & & & Whakaihuwaka Formation \\
\hline & & & & & & & $\begin{array}{l}\text { Te Rimu Sandstone } \\
\text { Whauteihi Formation }\end{array}$ \\
\hline \multirow{4}{*}{\multicolumn{2}{|c|}{ 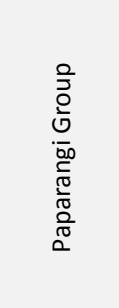 }} & \multirow{4}{*}{$\begin{array}{c}\text { Wilkies Shellbed } \\
\text { Makomako Sand } \\
\text { Mangaweka Mudstone }\end{array}$} & \multirow{4}{*}{\multicolumn{2}{|c|}{$\begin{array}{l}\frac{0}{3} \\
0 \\
\frac{0}{0} \\
\frac{0}{00} \\
\frac{0}{0} \\
\frac{0}{0} \\
\frac{0}{0} \\
\frac{0}{0}\end{array}$}} & \multirow{4}{*}{$\begin{array}{l}\text { Cable Siltstone } \\
\text { Wilkies Shellbed } \\
\text { Makomako Sand } \\
\text { Mangaweka Formation }\end{array}$} & & Wilkles Shellbed \\
\hline & & & & & & \multirow{3}{*}{ 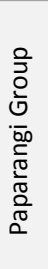 } & $\begin{array}{c}\text { Makomako Sandstone } \\
\text { Moukuku Formation } \\
\text { Oure Shellbed }\end{array}$ \\
\hline & & & & & & & Pitangi Sandstone \\
\hline & & & & & & & Mangaweka Mudstone \\
\hline
\end{tabular}

Table 1.5.2: Lithostratigraphic scheme in eastern Whanganui Basin after Naish et al. (1995).

\begin{tabular}{|c|c|c|c|c|c|}
\hline \multicolumn{2}{|c|}{$\begin{array}{c}\text { Superior Oil Company } \\
\text { of NZ (1943) }\end{array}$} & \multirow{2}{*}{\multicolumn{2}{|c|}{$\begin{array}{l}\text { Fleming (1953) } \\
\text { Maxwell Group }\end{array}$}} & \multicolumn{2}{|r|}{ Naish and Kamp (1995) } \\
\hline \multirow{3}{*}{ 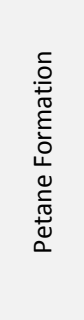 } & \multirow{3}{*}{$\begin{array}{c}\text { Mangamako Sand } \\
\text { Ohingaiti Sand }\end{array}$} & & & \multirow{6}{*}{ 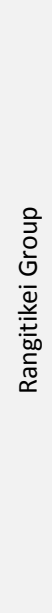 } & Vinegar Hill Formation \\
\hline & & \multirow{2}{*}{ 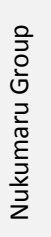 } & \multirow{2}{*}{$\begin{array}{c}\text { Waipuru Shellbed } \\
\text { Mangamako Shellbed } \\
\text { Ohingaiti Sand }\end{array}$} & & $\begin{array}{l}\text { Mangaonoho Formation } \\
\text { Mangamako Shellbed }\end{array}$ \\
\hline & & & & & $\begin{array}{l}\text { Orangipongo Formation } \\
\text { Ohingaiti Sand }\end{array}$ \\
\hline \multirow{3}{*}{ 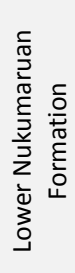 } & \multirow{3}{*}{$\begin{array}{c}\text { Hautawa Reef } \\
\text { Basal Nukumaruan Sand }\end{array}$} & \multirow{3}{*}{$\begin{array}{l}\text { Oे } \\
0 \\
0 \\
0 \\
\frac{\pi}{2} \\
\text { o }\end{array}$} & \multirow{3}{*}{$\begin{array}{c}\text { Tuha Sand } \\
\text { Hautawa Shellbed } \\
\text { Te Rimu Sand }\end{array}$} & & $\begin{array}{l}\text { Makohine Formation } \\
\text { Tuha Sand }\end{array}$ \\
\hline & & & & & $\begin{array}{l}\text { Tikapu Formation } \\
\text { Hautawa Shellbed }\end{array}$ \\
\hline & & & & & $\begin{array}{l}\text { Mangarere Formation } \\
\qquad \text { Te Rimu Sand }\end{array}$ \\
\hline
\end{tabular}




\subsubsection{Eastern Whanganui Basin (Naish \& Kamp, 1995)}

Naish and Kamp (1995) describe six formations which make up the eastern stratigraphy for the Whanganui Basin at this time. These formations fall into a single Group which they name the Rangitikei after Fleming (1953). The Hautawa Shellbed forms the base of the Tikapu Formation in this scheme. The Tikapu Formation contains two members which are categorised into a basal coquina and a gradationally overlying siliciclastic siltstone. Naish and Kamp (1995) consider that the faunal changes within the Hautawa Shellbed represent a progressive increase from inner to mid-shelf water depth. While in the siltstone, there is successive arrivals of fauna interpreted as shallowing from midshelf to inner shelf.

\subsubsection{Summary stratigraphy Whanganui Basin}

Table 1.5.3 shows the complex nature of the stratigraphy across the basin. Clearly, many formations do not have lateral correlatives which extend from west to east. In simple terms, the Whariki Formation of McIntyre \& Kamp (1998), is a lateral continuation in the west of the lower Tikapu Formation of Naish \& Kamp (1995). Both the west and eastern regions express the same depositional changes associated within the Hautawa Shellbed and overlying sediments. Everywhere the Hautawa Shellbed represents a period of rapid shoreline transgression out of a marine lowstand.

\subsubsection{Lateral correlations}

Consideration has been repeatedly given to the major changes observed across the Whanganui Basin (west to east). In the western-most segment of the basin, the Hautawa Shellbed is inferred by McIntyre (2002) to be represented by a correlative formation: the Kuranui Limestone. The Kuranui Limestone, prior to the findings of Mclntyre (2002), was thought to be equivalent to the Upokonui Sandstone (Fleming, 1953), which is found overlying the Hautawa Shellbed elsewhere (Mclntyre \& Kamp, 1998). Though, the Kuranui Limestone has a break in sedimentation at its base, 
Table 1.5.3: Modern stratigraphy of the Whanganui Basin at the Mangapanian-Nukumaruan boundary. Formation names are left justified and named members right justified.

\begin{tabular}{|c|c|c|c|c|c|c|}
\hline \multicolumn{3}{|r|}{ Western Basin } & \multicolumn{2}{|r|}{ Eastern Basin } & Stage & Series \\
\hline \multirow{7}{*}{ 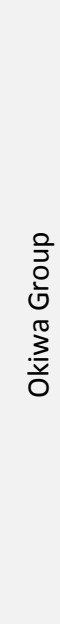 } & \multirow{3}{*}{$\begin{array}{l}\text { o. } \\
\text { 음 }\end{array}$} & Wickham Formation & \multirow{7}{*}{ 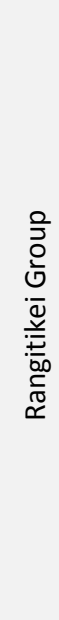 } & \multirow{3}{*}{ Tikapu Formation } & \multirow{3}{*}{ 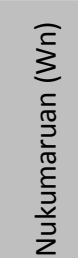 } & \multirow{7}{*}{ 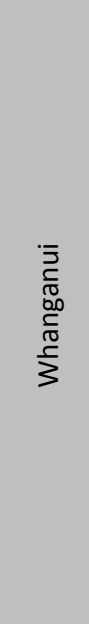 } \\
\hline & & Shaw Formation & & & & \\
\hline & & $\begin{array}{c}\text { Upokonui Sandstone } \\
\text { Whariki Formation } \\
\text { Hautawa Shellbed }\end{array}$ & & & & \\
\hline & \multirow{4}{*}{ 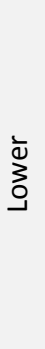 } & $\begin{array}{l}\text { Parikino Formation } \\
\text { Caseley Conglomerate }\end{array}$ & & \multirow{4}{*}{ Mangarere Formation } & \multirow{4}{*}{ 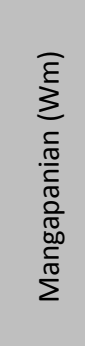 } & \\
\hline & & $\begin{array}{l}\text { Tirotiro Formation } \\
\text { Parihauhau Shellbed }\end{array}$ & & & & \\
\hline & & Whakaihuwaka Formation & & & & \\
\hline & & $\begin{array}{c}\text { Te Rimu Sandstone } \\
\text { Whauteihi Formation } \\
\text { Wilkies Shellbed }\end{array}$ & & & & \\
\hline
\end{tabular}

as described by Suggate (1990), and this is cause for some concern with the interpretation that the Kuranui and Hautawa Shellbed are lateral correlatives. Whether the Kuranui Limestone is in fact a correlative or not is outside the scope of this thesis.

As previously mentioned, the cold-water assemblage (including Zygochlamys delicatula) is also found in other North Island sedimentary basins during the Nukumaruan Stage. Some of the other key formations include the Sentry Box Limestone in central inland Hawke's Bay (R. Cooper \& Agterberg, 2004), and the Table Flat Shell Conglomerate at the western edge of the Ruahine Range. The correlations to these other formations are tenuous and relies primarily on the presence of Zygochlamys delicatula as an indicator species. Figure 1.5.1, taken from the GNS Science QMAP publication on the geology of Hawke's Bay, show how these formations relate to each other within a schematic cross-section of the North Island basins. The Hautawa Shellbed is interestingly shown to fade from green to blue, representing a suggested gradational change from a limestone into conglomerate facies.

Sediments deposited in the two youngest paleo-seaways across the central North Island (the Manawatu and Kuripapango Straits) contain poorly preserved Zygochlamys delicatula specimens. This suggests that both seaways were open during 
Used with permission of KJ Bland and M Rattenbury; GNS Science

4
वे
0
0
8
0
5
$\frac{8}{0}$
$\frac{8}{0}$

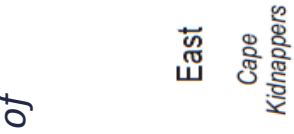

赵

营

әu!̣!ฺu $\forall$ ә6pıy uosew

डิ

$\overleftarrow{5}$

U

ปั

$+\frac{1}{2}$

ज纺

$\infty$ i
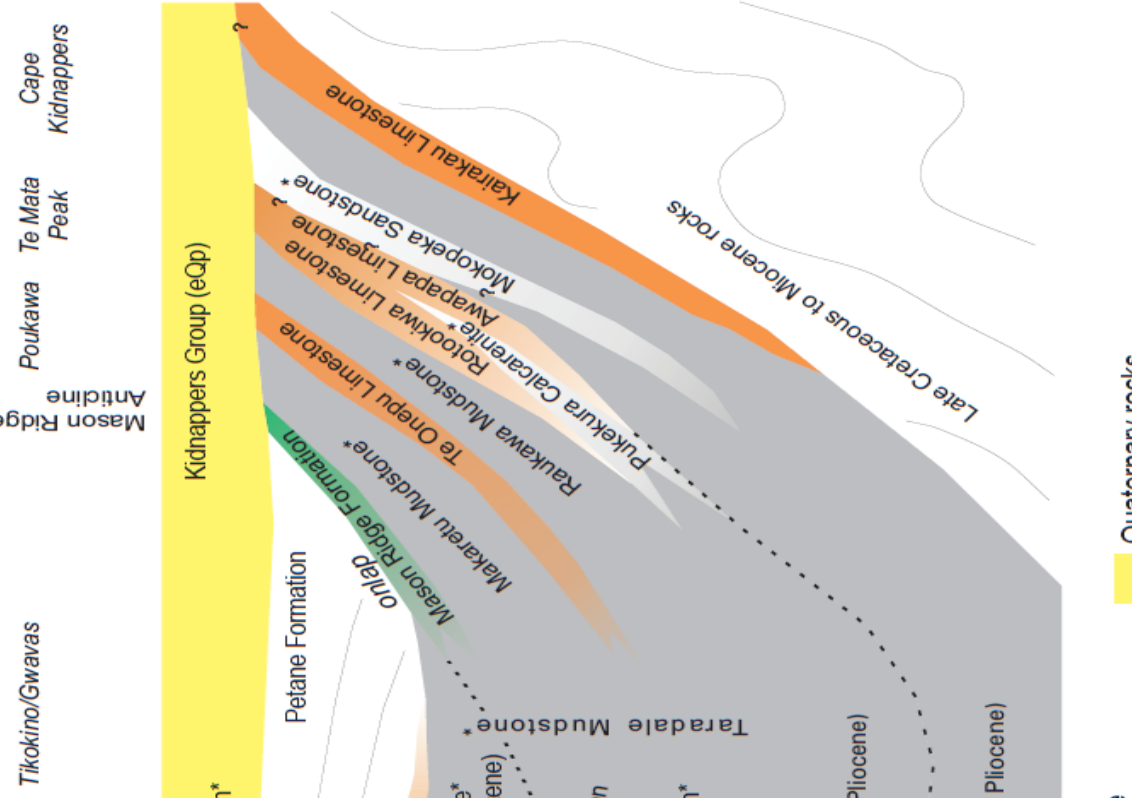

ज)

ริ

on

ई

$\S$.

0

ธิ ฮ

ㅊำ

ㅇํㅇ

वे ज

o

옹

$\leqq$

ธิ 우

究

î

ญิ बे

记

iे

है दे

ज् वे

-i

เi

-i

논

눈
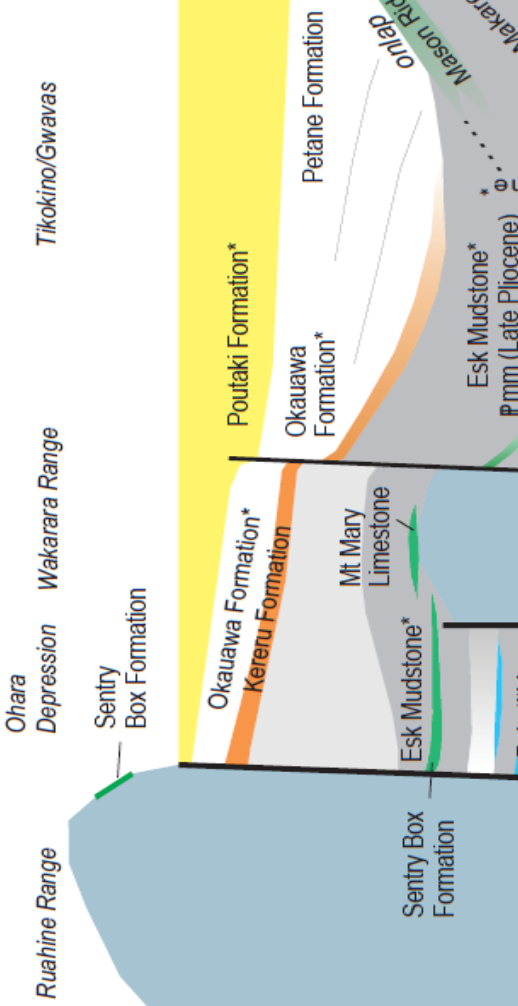

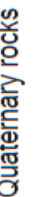

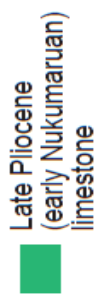
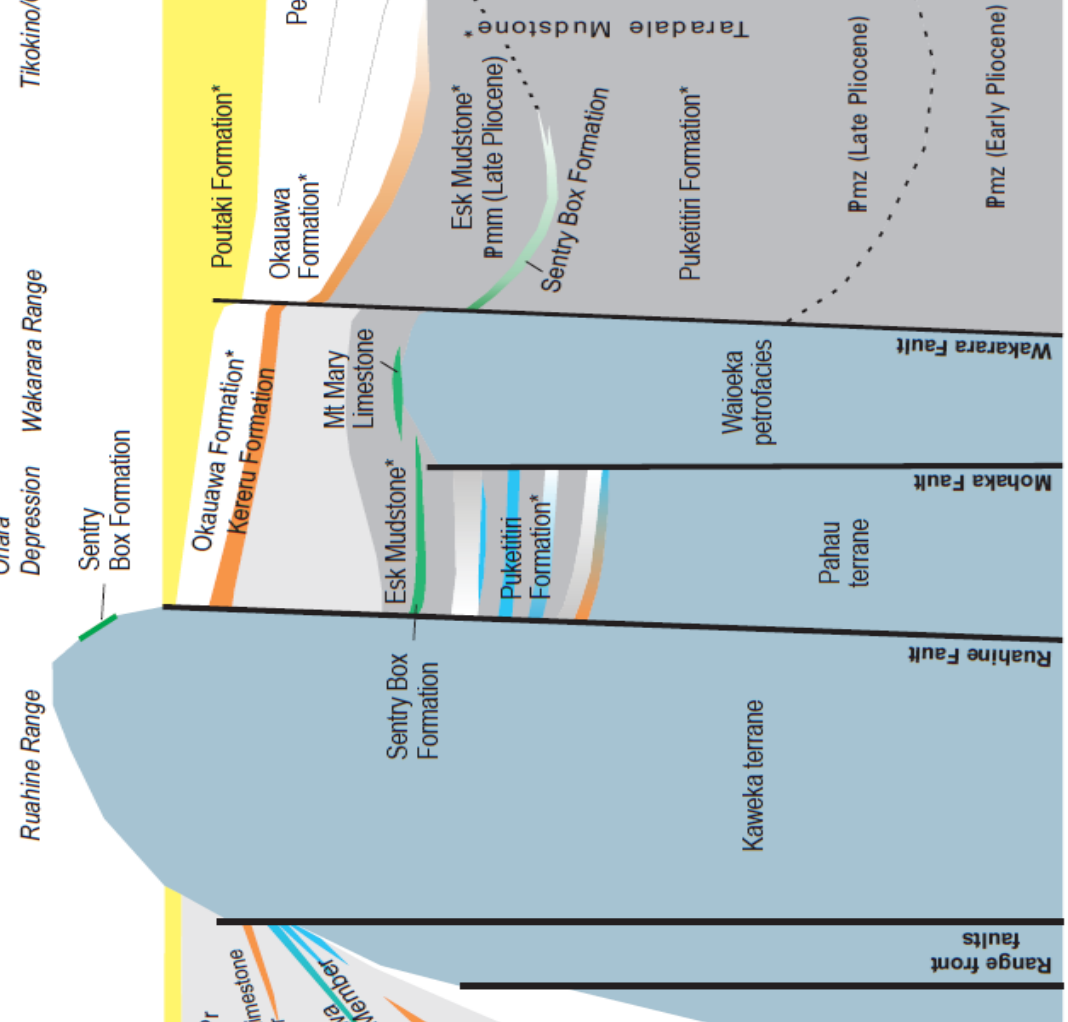

$\frac{\text { 들 }}{\frac{0}{0}}$

ㄴ

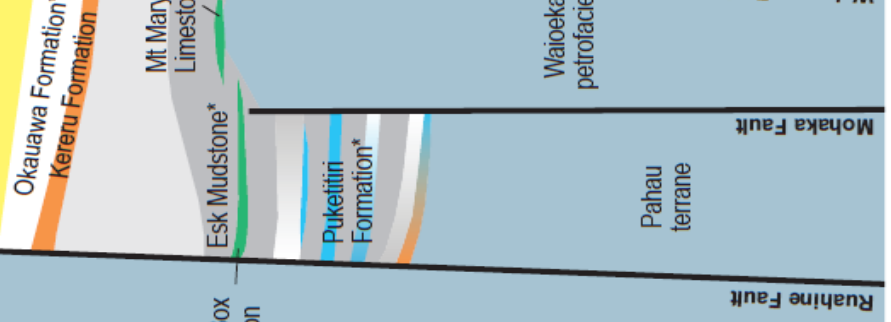

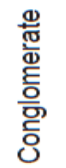
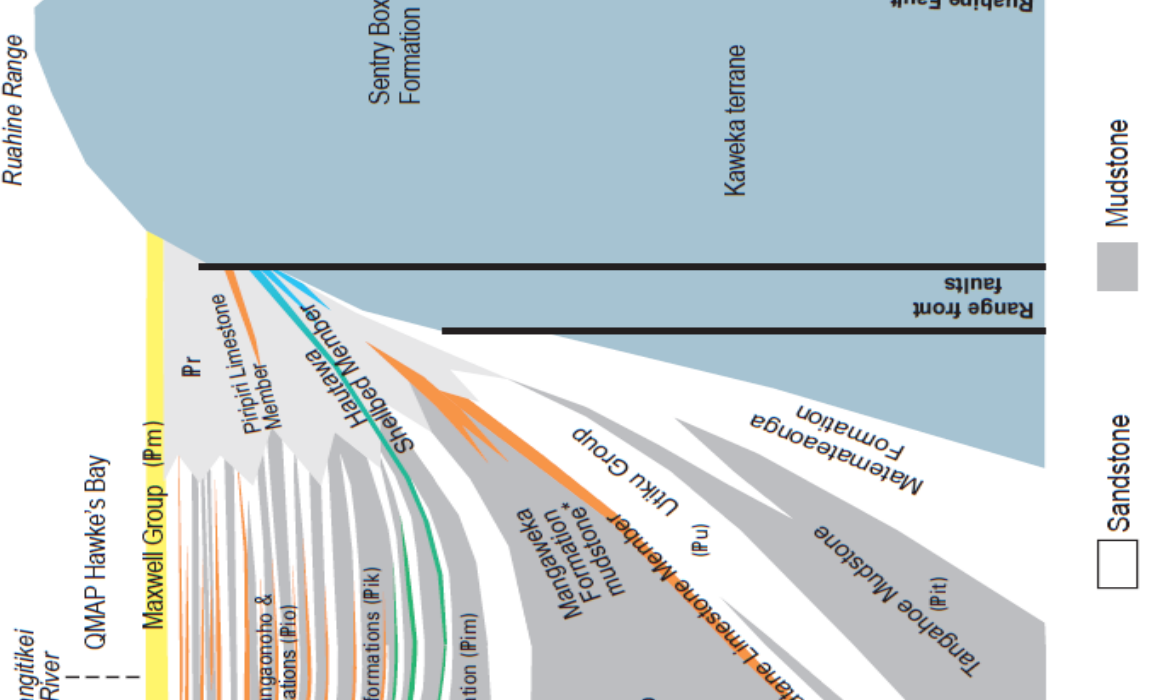

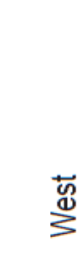

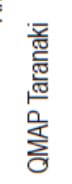

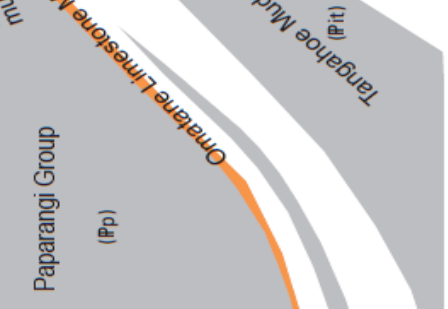

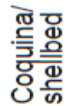


the early Nukumaruan - even if only during marine highstand periods. Hence, the East Coast and Whanganui Basins were probably connected to some degree at this time, with a chain of islands between them formed by the proto-Ruahine Range.

\subsection{OTHER STRATIGRAPHIC APPROACHES}

\subsubsection{Biostratigraphy}

As shown in Figure 1.5.1 and described above, the Hautawa Shellbed is of basal Nukumaruan age which is tied to the arrival of Zygochlamys delicatula into the Whanganui Basin. This timing can be correlated to events elsewhere due to a number of key biomarkers present in the base of the Hautawa Shellbed [Table 1.6.1]. There has been concern that presence of Zygochlamys delicatula may be stratigraphically diachronous and its use as a marker is best suited to very local scales (Jenkins, 1971). Hence, using an assemblage of key species is important rather than a single taxon to mark a chronostratigraphic horizon within the Whanganui Basin.

Table 1.6.1 shows some of the key faunal assemblage changes associated with the boundary between the Mangapanian and Nukumaruan Stages in the Whanganui Table 1.6.1: Bioevent markers situated in the Hautawa Shellbed, adapted from Table 7.1 Mclntyre (2002) pg. 233.

Orange = taxa with Mangapanian Stage $(\mathrm{Wm})$ last appearance; Red = taxa considered $\mathrm{Wm}$ restricted/last appearance elsewhere but also found in in the base of the Hautawa Shellbed; Lilac = taxa with first appearance in the base of the Hautawa Shellbed and continue into the Nukumaruan Stage (Wn); Blue= Nukumaruan Stage first appearance taxon not recorded in the base of the Hautawa Shellbed.

\begin{tabular}{|c|c|c|}
\hline $\begin{array}{c}\text { Mangapanian } \\
\text { (last appearance) }\end{array}$ & $\begin{array}{c}\text { Base of the } \\
\text { Hautawa Shellbed }\end{array}$ & $\begin{array}{c}\text { Nukumaruan } \\
\text { (first appearance) }\end{array}$ \\
\hline & & Alcithoe arabica \\
\hline & \multicolumn{2}{|c|}{ Tawera subsulcata } \\
\hline & \multicolumn{2}{|c|}{ Phialopecten triphooki } \\
\hline & \multicolumn{2}{|c|}{ Zygochlamys delicatula } \\
\hline & \multicolumn{2}{|c|}{ Mesopeplum convexum } \\
\hline \multicolumn{2}{|c|}{ Crassostrea ingens } & \\
\hline \multicolumn{2}{|c|}{ Phialopecten thomsoni } & \\
\hline Polinices (s.s.) & & \\
\hline Clavatoma pulchra & & \\
\hline Maoricardium spatiosum & & \\
\hline Alcithoe gatesi & & \\
\hline Austrofusus pagoda & & \\
\hline
\end{tabular}


Basin and elsewhere in New Zealand. The fauna last appearing in the Mangapanian Stage [orange; Table 1.6.1] are not seen in the Hautawa Shellbed. Some species which generally are elsewhere considered to last appear in the Mangapanian Stage are found within the basal Hautawa Shellbed - such as Crassostrea ingens and Phialopecten thomsoni [red; Table 1.6.1]. The key fauna which are first observed in Whanganui Basin in the base of the Hautawa Shellbed (and not older units) are shown in lilac. While in contrast, Alcithoe arabica only occurs in strata of Nukumaruan age and younger [blue; Table 1.6.1].

\subsubsection{Chronostratigraphy}

The Whanganui Basin sedimentary sequence is mostly made up of coastal plain, shoreface and shelfal marine cyclothem deposits. Hence, deposition in the Whanganui Basin occurred dominantly during the late rise, highstand and falling part of each glacioeustatic cycle (Naish et al., 1998). This means that a dominantly odd-numbered Marine Isotope Stage (MIS) record is preserved in the Whanganui Basin. This relates to interglacial periods being recorded as odd stage numbers and glacial periods as even numbers. For example, the modern day inter-glacial highstand is MIS 1 while the most recent glacial period is MIS 2, and the interglacial before that is MIS 3.

The correlation of the Hautawa Shellbed with the MIS record has been debated in the past. Most recently, Cooper \& Agterberg (2004) proposed the move from corresponding to MIS 97 (as previously positioned by Naish \& Kamp (1995) and Kamp \& Mclntyre (1998)), to a new correlation with MIS 95. This relates to a change from an age of 2.46 to $2.40 \mathrm{Ma}$, respectively. Today, the base Hautawa Shellbed is suggested to mark the base of the Nukumaruan Stage at an age of $2.40 \mathrm{Ma}$, with the lowest occurrence (LO) of Zygochlamys delicatula, in the Whanganui Basin as recommended by Beu (2001) (Hollis et al., 2010). 


\subsection{SEQUENCE STRATIGRAPHY}

The position of the Hautawa Shellbed within a sequence stratigraphic framework has been repeatedly investigated in detail as part of the wider Whanganui Basin sequences. This work has primarily been done in Rangitikei area (Journeaux, Kamp, \& Naish, 1996; Naish \& Kamp, 1995) and at Parikino in the Whanganui River valley (Kamp \& McIntyre, 1998; McIntyre \& Kamp, 1998). The purpose of sequence stratigraphy is to correlate and untangle the observed repeating sedimentary record with cyclic sea level changes. In the case of the Whanganui Basin cyclothems, they are dominantly glacioeustatic in nature.

Table 1.7.1 outlines abbreviations common to sequence stratigraphy and used here. Definitions and terms are based generally on Catuneanu (2002). Due to the complexities of sequence stratigraphic terminology, a summary is given before describing the implications and details relating to the Hautawa Shellbed outlined later in Table 1.7.2.

Table 1.7.1: Abbreviations common to sequence stratigraphy.

\begin{tabular}{c|lc|l} 
Abbreviation & Full term & Abbreviation & Full term \\
\hline TST & Transgressive systems tract & DLS & Downlap surface \\
HST & Highstand systems tract & LFS & Local flooding surface \\
RST & Regressive systems tract & MFS & Maximum flooding surface \\
LST & Lowstand systems tract & & \\
& & OLSb & Onlap shellbed \\
SB & Sequence boundary & BLSb & Backlap shellbed \\
RSE & Regressive surface of erosion & DLSb & Downlap shellbed \\
TSE & Transgressive surface of erosion & MCSb & Mid-cycle shellbed
\end{tabular}

\subsubsection{Nomenclature}

The idea of systems tracts has developed in order to subdivide individual sequences into contemporaneous depositional units which develop in different environments on the marine shelf and slope (Catuneanu, 2002). The systems tract to which a unit is assigned is based on the bounding surfaces and the position of the unit within the sequence. A complete cyclothem contains both transgressional and regressional portions which are represented by retrogradational and progradational stacked facies 
Figure 1.7.2: Facies stacking due to transgressive and regressive sea level changes from Catuneanu (2002).

A) Model of a schematic shelf. B) Reterogradation observed in stacked facies due to marine transgression. C) Progradation observed in stacked facies due to marine regression.

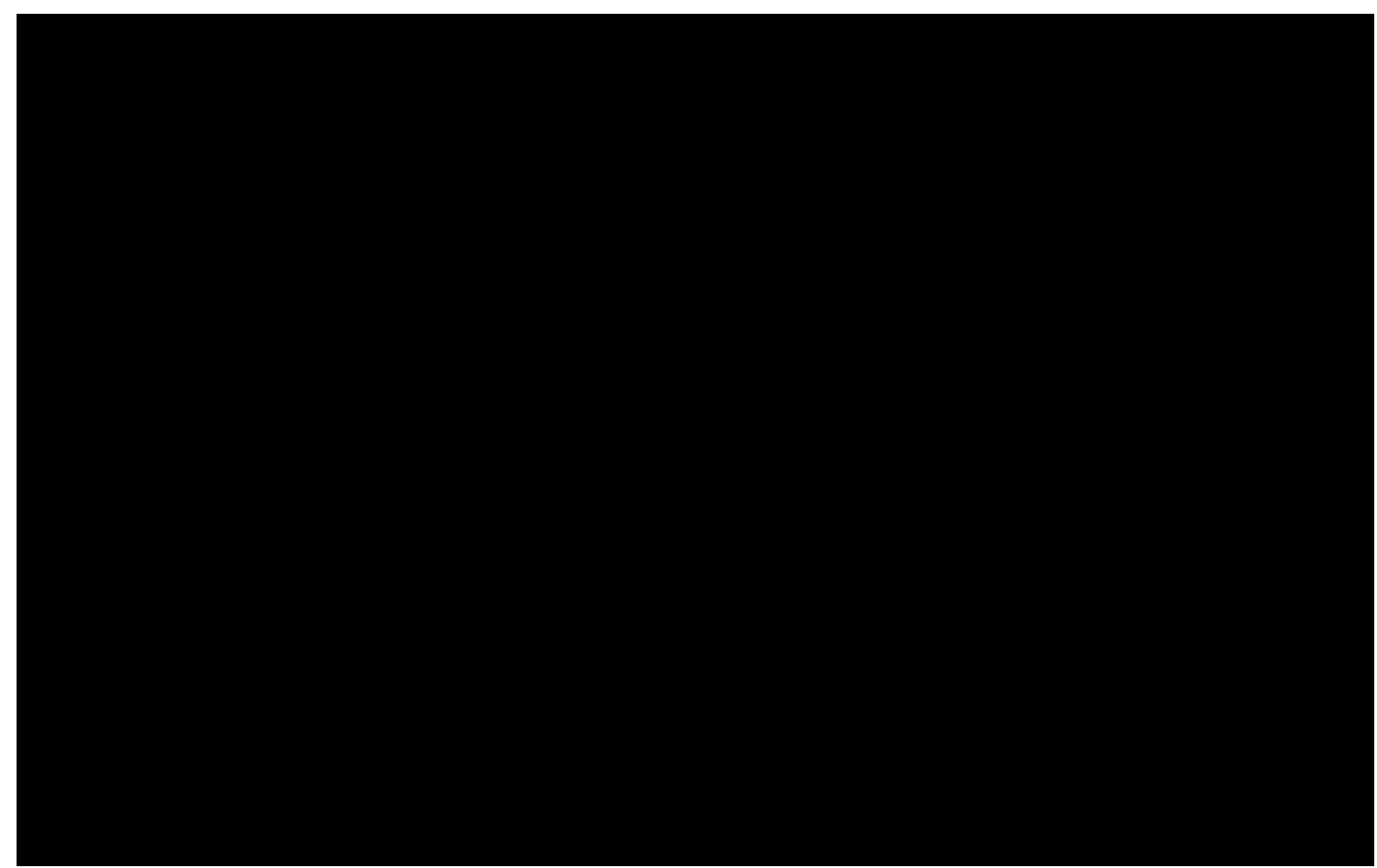

Figure 1.7.1: Stratal terminations and terminology from Catuneanu (2002).

Only onlap, downlap, and toplap are described here. Backlap of Kidwell (1991) is not shown. 
changes [Fig. 1.7.1]. Changes in relative sea level cause lateral facies shifts (Catuneanu, 2002). Reterogradation relates to facies stacking from a transgressional sea level change i.e. a landward movement of a shoreline. Progradation is the opposite and develops during a regressional change in sea level with seaward migration of the shoreline (Catuneanu, 2002).

Figure 1.7.2 shows the stratal relationships which relate to terminology used in relation to sequence stratigraphy taken from Catuneanu (2002). Backlap deposition is not included in descriptions by Catuneanu (2002) but is the "termination of beds at the distal, basinward edge of a ... retrogradational body" (pg. 687) (Kidwell, 1991).

There are four types of systems tract discussed here: transgressive, highstand, regressive, and lowstand [Fig. 1.7.3]. Due to Whanganui Basin cyclothems usually not expressing preserved lowstand strata this phase will not be explained here. Figure 1.7.3 shows a schematic of the relationship between different system tracts and their bounding surfaces compared to change in sea level as time passes from left to right. The most significant surfaces are the sequence boundaries (SB) which are unconformities (and their correlative conformities) which bound each sedimentary expression of a single sea level cycle i.e. each cyclothem.

Figure 1.7.3: Systems tracts and their bounding surfaces relative to sea level change. Time passes left to right. Key in box applies to Figures 1.7.3 to 1.7.6.

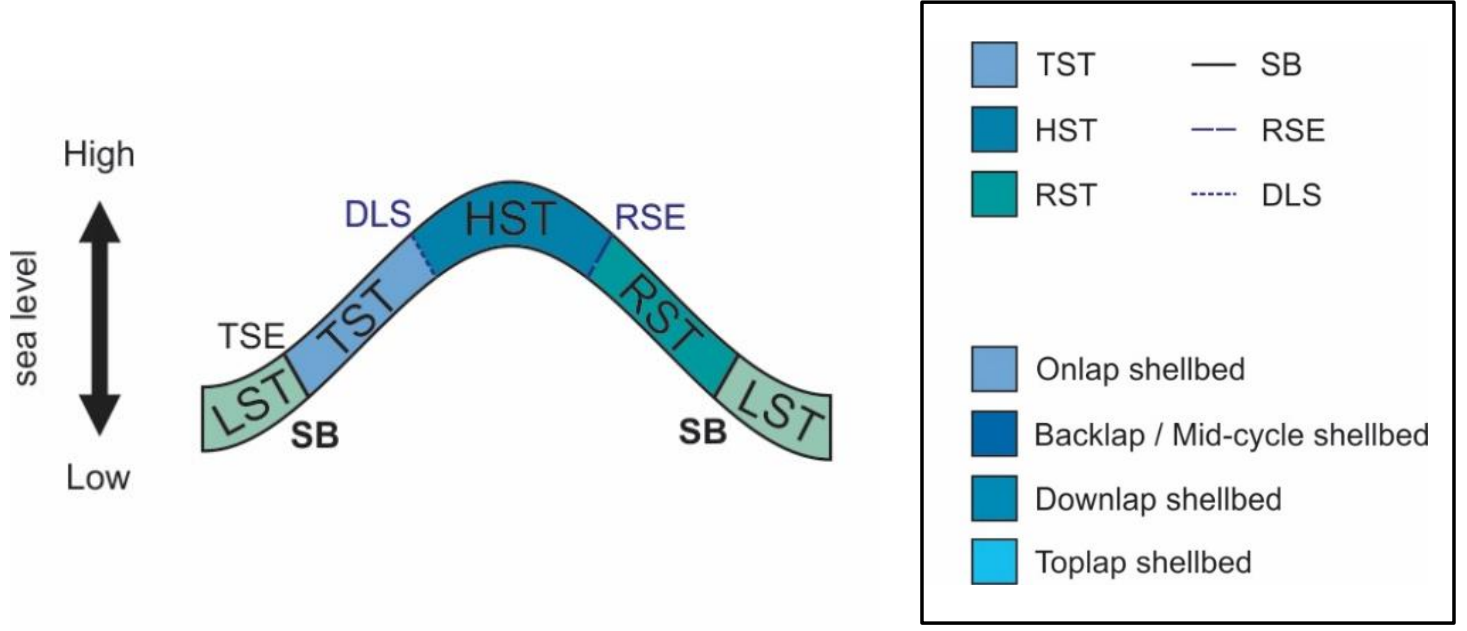


The transgressive systems tract (TST) is bounded below by the transgressive surface of erosion (TSE) [Fig. 1.7.3 and 1.7.4]. Strata onlaps onto the TSE during an increase in relative sea level often by the reworking of shallower deposits downslope early in the TST. During TST sedimentation and basin infill is outpaced by sea level rise (Catuneanu, 2002). The TST results in a deepening upward succession being deposited in a single location due to relative sea level rise. During transgression, the shelf can be starved of sediment and this is expressed by the stratigraphic condensation of transgressive strata (McIntyre \& Kamp, 1998).

An onlap shellbed can form early during the TST when shell dominated inner shelf-depth sediments deposit onto the TSE (Hendy et al., 2006) [Fig. 1.7.3]. This is also referred to as a transgressive lag deposit and tends to be dominated by reworked innershelf fauna. Late in the TST a backlap shellbed may form when terrigenous sediment supply is less. This shellbed is often dominated by epifaunal and hardground preferring specimens. Onlap shellbeds may grade up into a less condensed siliciclastic wedge nearer to shore during the TST or directly into a backlap shellbed in a deeper setting [Fig. 1.7.4]. When onlap and backlap shellbeds are superimposed they are referred to as amalgamated (Kondo et al., 1998) or compound (Naish \& Kamp, 1997b). These terms apply when the downlap surface converges toward the sequence boundary due to slower sedimentation deeper water setting (Naish \& Kamp, 1997b). This results in the superposition of elements from both onlap and backlap shellbeds. Therefore, this is condensation in the context of both onlap and backlap as described by Kidwell (1991).

Figure 1.7.4: Transgressive systems tract (TST) schematic. Shoreline to the left, and basin to the right. Upper shows systems tract. Lower shows shellbed deposits.

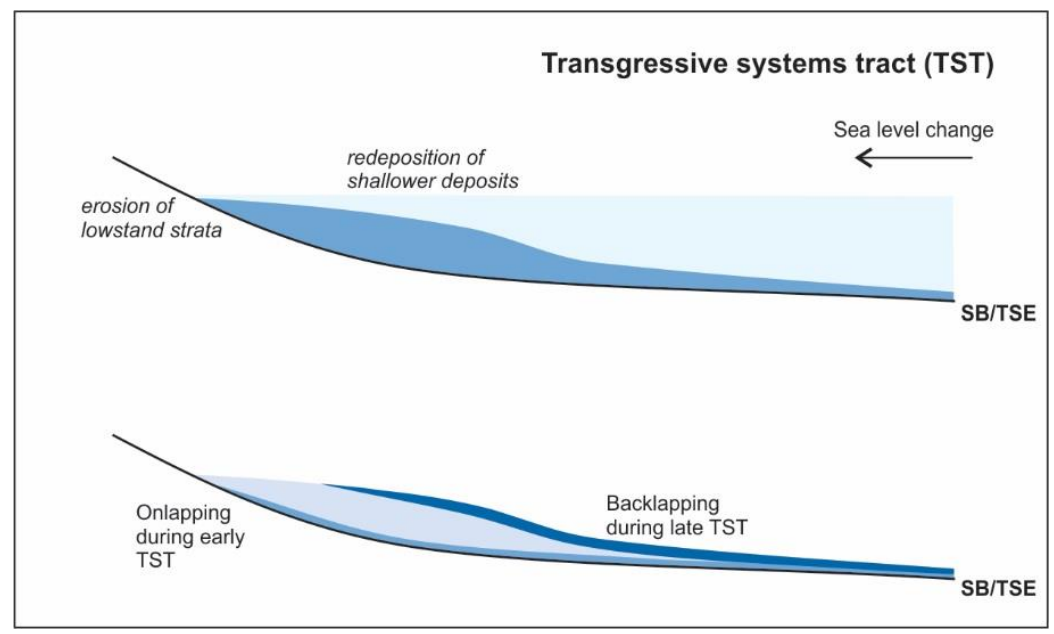


In contrast, when the onlap and backlap shellbeds are separated by a terrigenoclastic wedge, the backlap shellbed may also be referred to as a mid-cycle shellbed (Saul, Naish, Abbott, \& Carter, 1999). A mid-cycle shellbed is bounded by a local flooding surface (LFS) below, and the downlap surface (DLS) above (Abbott, 1997).

When the relative sea level rise drops below the sedimentation rate, the highstand systems tract (HST) is reached [Fig. 1.7.5] (Catuneanu, 2002). This occurs toward the end of a relative sea level change but not only at the maximum [Fig. 1.7.3]. The HST is bound below by the DLS of the sequence. During the HST either or both of toplap or downlap of strata may occur. At the base of the HST a downlap shellbed may form where shelly material accumulates in the siltstone (Naish \& Kamp, 1997b). This downlap shellbed tends to be matrix dominated and contains a diverse mixture of epi- and infaunal species (Naish \& Kamp, 1997b).

Figure 1.7.5: Highstand systems tract (HST) schematic. Shoreline to the left, and basin to the right. Upper shows systems tract. Lower shows shellbed deposits.

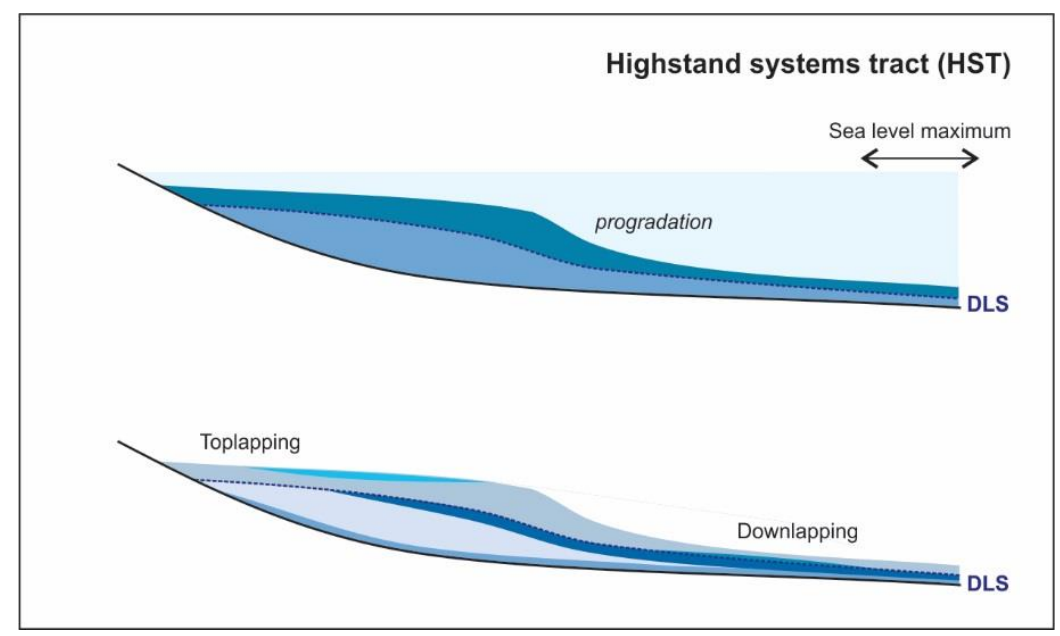

As relative sea level falls, the landward side of a basin may become aerially exposed as the regressive systems tract (RST) develops in the basin [Fig. 1.7.6]. The RST is bounded below by the regressive surface of erosion (RSE) which forms as the shoreline advances causing reworking of recent deposits. The RST causes deposition of shallower environments up section in a cyclothem as the relative sea level fall is persevered in a single location. Following deposition of a RST, a lowstand systems tract (LST) is formed when sedimentation is faster than sea level fall [Fig. 1.7.3] (Catuneanu, 2002). 
Figure 1.7.6: Regressive systems tract (HST) schematic. Shoreline to the left, and basin to the right. Upper shows systems tract. Lower shows shellbed deposits.

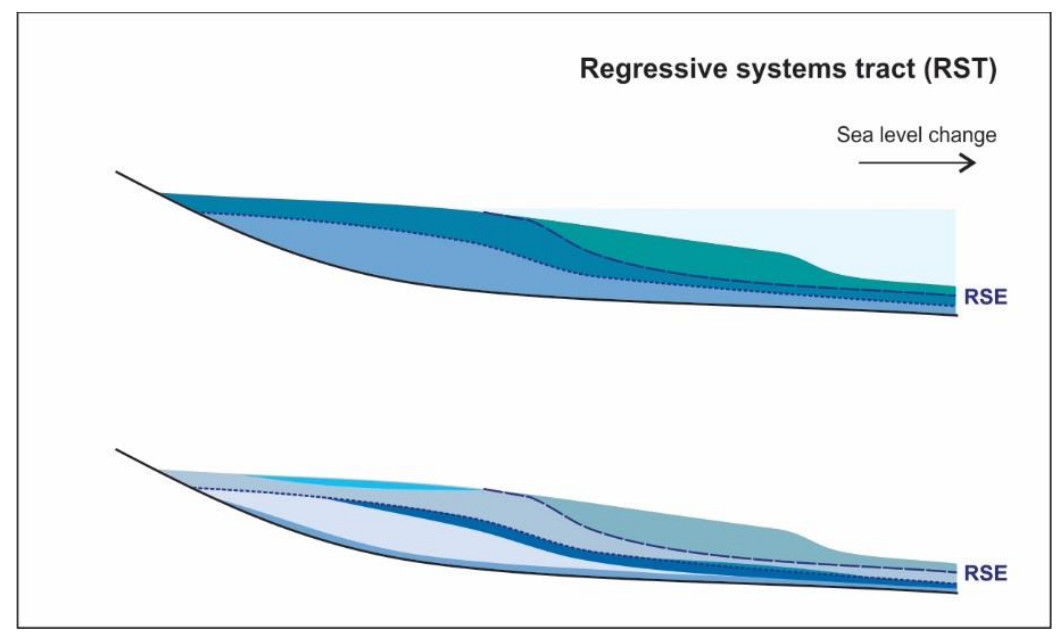

\subsubsection{Whanganui Basin sequences}

Prior work in Whanganui Basin has correlated the base of the marine transgression as the base of each cyclic sequence (Kamp \& Mclntyre, 1998; Kondo et al., 1998; Naish \& Kamp, 1997b; Saul et al., 1999). Therefore, the SB of the cyclothem are also the TSE in Whanganui Basin (Kamp \& Mclntyre, 1998; Naish \& Kamp, 1997b). This unconformity occurs as underlying strata are eroded during rapid sea level rise as the shoreline moves landward during marine transgression. The result of this is that the Whanganui cyclothem record is usually missing the lowstand systems tract and late regressional strata (Naish \& Kamp, 1997b).

It is generally accepted that sea level oscillated between 20 to $120 \mathrm{~m}$ in Milankovitch-paced cycles in the Pliocene-Pleistocene (Naish, 2005). Sequence stratigraphy combined with high resolution oxygen isotope work has shown that the strata in Whanganui Basin provide direct evidence of these global sea level changes (Naish, 2005; Naish et al., 1998).

\subsubsection{Sequence architecture}

Table 1.7.2 summarises the key characteristics of shellbeds described elsewhere and are applicable to the Hautawa Shellbed (Kondo et al., 1998; Naish \& Kamp, 1997b; Saul et al., 1999). There is a distinctive contrast between sequence motif architecture between the Rangitikei and Turakina river valleys (Naish et al., 1998; Naish \& Kamp, 
Figure 1.7.7: Symmetric Turakina motif compared to asymmetric Rangitikei motif.

The term motif refers to the pattern preserved in outcrop due to sediments native position relative to the paleo-shoreline. Modified after Naish and Kamp (1997).

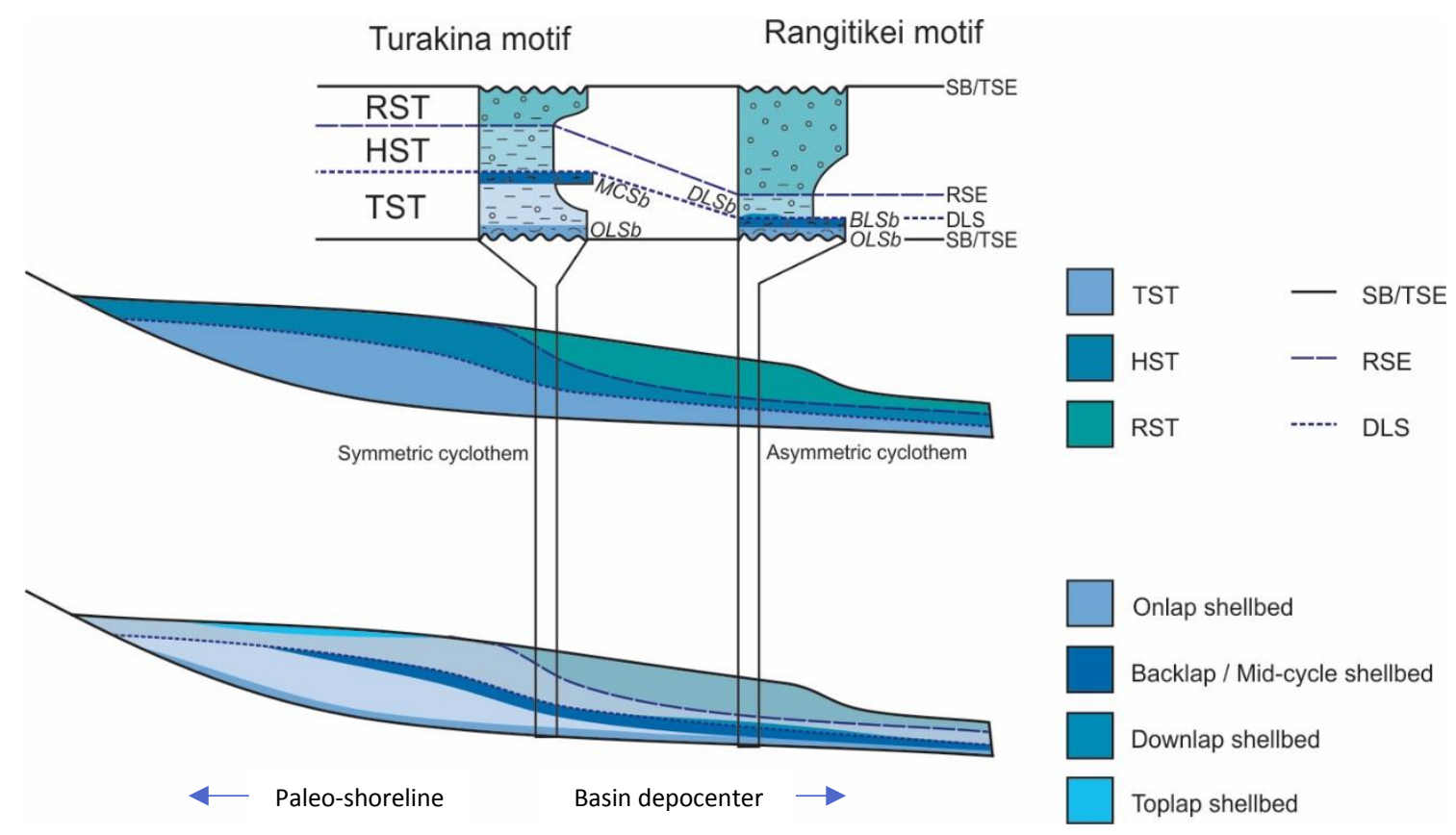

1997b) [Fig. 1.7.7]. The 'motif architecture' relates to the distribution of sediment thickness compared to the systems tracts during which strata were depositied.

The Turakina symmetric cyclothem motif is interpreted to represent a shallower shelfal location [Fig. 1.7.7] (Kondo et al., 1998; Saul et al., 1999). The TST contains thicker sedimentation in a shoreline connected sediment wedge due to being more proximal to the paleo-shoreline (Naish \& Kamp, 1997b). This thicker TST causes the cyclothem to have a symmetric architecture - thickness more evenly distributed between TST vs combined HST and RST [Fig. 1.7.7]. In contrast the Rangitikei motif characterises a distinct condensed transgressive stratigraphy of Kidwell (1991) [Fig. 1.7.7]. Hence, the preserved transgressive systems track is thinner and the cyclothem is asymmetrical. Naish and Kamp (1997b) conclude that the motif observed is directly controlled by the area of the paleo-shelf which is exposed in outcrop.

\subsubsection{Implications from sequence architecture}

McIntyre (2002) suggested that the depositional environment expressed in Whanganui Basin strata progresses to deeper water depths with increasing distance eastward from the Whanganui River valley. Parikino, further westward again from the 
modern Turakina Valley, would theoretically represent an even more shallow position on the paleo-shelf if McIntyre (2002)'s hypothesis was correct. But the cyclothem containing the Hautawa Shellbed observed at Parikino (as described by McIntyre and Kamp (1998)) is similar to the Turakina motif, i.e. this cyclothem has an expanded TST and not a compound onlap-backlap shellbed. This implies that there is not consistent further shallowing between the Whanganui and Turakina River valley sequences.

An asymmetric cyclothem motif has also been suggested to equate to a basin where subsidence is moderate to high (1-2 m/ka) (Pillans et al., 1998). Pillans et al. (1998) infer that this causes an experienced rapid transgression during deglaciation and also more gradual regressional shoaling. Hence, the architecture of the cyclothem is typically dominated by a condensed TST and thick HST-RST (Pillans et al., 1998).

\subsubsection{The 'Hautawa Shellbed'}

Naish and Kamp (1997) describe the lowest part of the Hautawa Shellbed in the Rangitikei River section as being a 'transgressive lag' and onlap shellbed. This rapidly changes upsection into an in situ assemblage upper segment made up of molluscs, brachiopods and bryozoans which forms the backlap shellbed (Naish \& Kamp, 1997b). They observed that the reworked shells are mostly of shallow-water derivation, those found in the upper portion are of middle to outer shelf origin (Naish \& Kamp, 1997b). In the Rangitikei River section, the Hautawa Shellbed is bounded by a sequence boundary and TSE below, and the downlap surface above. It is also overlain by a separate, matrix supported downlap shellbed at the base of the HST. Therefore, the 'Hautawa Shellbed' designation is considered here to only apply to sediments deposited in the TST of this cyclothem. This is marked by the first arrival of the extant sub-Antarctic scallop Zygochlamys delicatula into Whanganui Basin. This is consitant with the definition of the Huatawa Shellbed used by other authors (e.g. Kamp \& Mclntyre, 1998; Kondo et al., 1998; McIntyre, 2002; McIntyre \& Kamp, 1998; Naish \& Kamp, 1995). Hautawa Shellbed can be expressed in either an asymetric or symmetric cyclothem. 


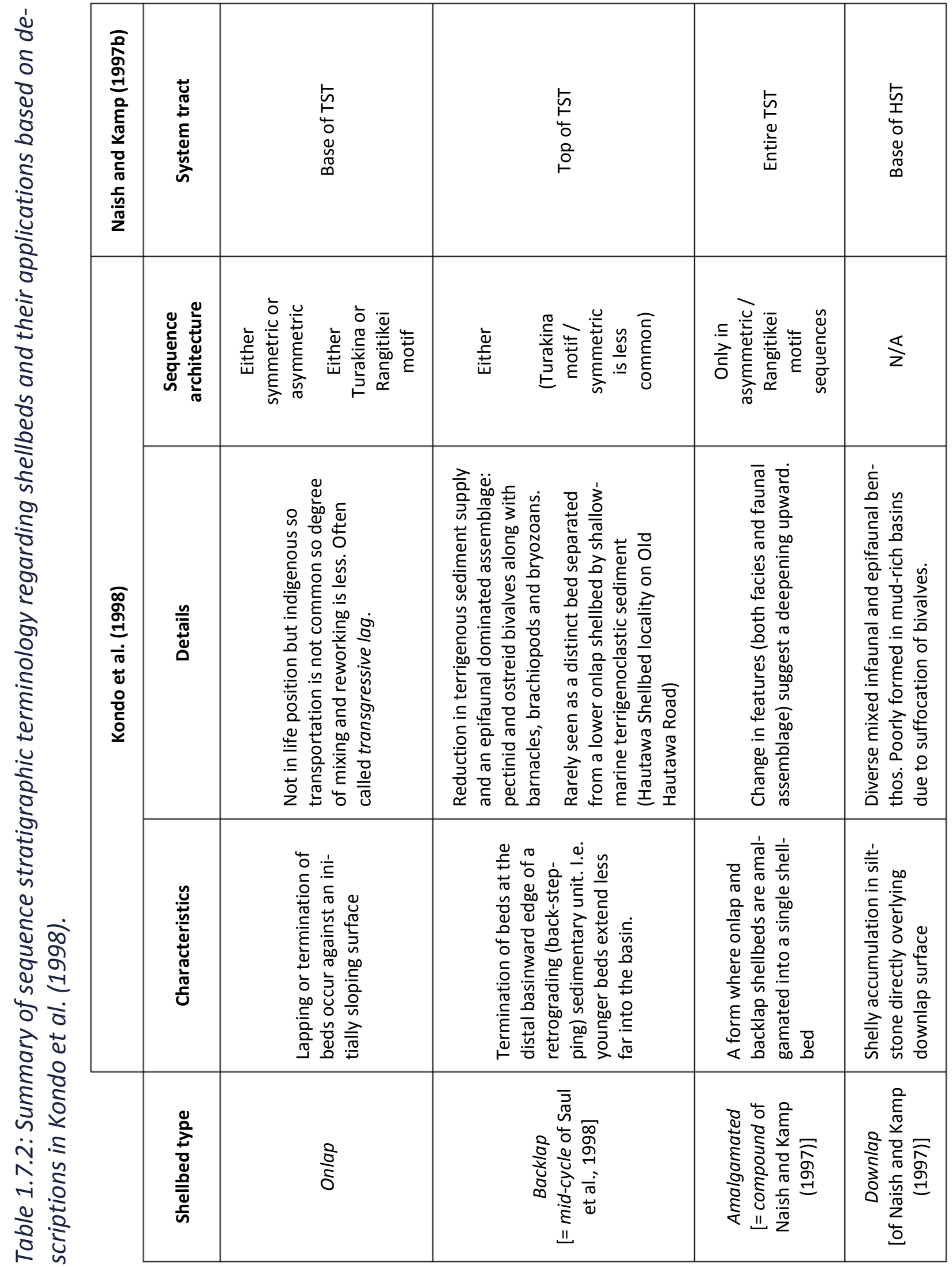




\subsection{PALEONTOLOGY}

\subsubsection{Introduction}

Fleming (1953) laid the groundwork for all subsequent palaeontological and stratigraphic studies which examined the sedimentary sequences preserved within the Whanganui Basin. This pioneering investigation included the designation of the type locality for the Hautawa Shellbed. This locality is on the Old Hautawa Road (which is now unused) beyond the end of West Road, referred to here as at 'West Road'.

It is common to use faunal assemblages to infer the environment of deposition of sedimentary strata. Faunas from the Hautawa Shellbed have been used this way starting with the work of Fleming (1953). A brief outline of the faunas recovered from the shellbed is given below.

\subsubsection{Macrofauna}

\section{Brachiopoda}

Four extant genera, from two separate orders of brachiopods, are identified in the Hautawa shellbed by Mclntyre (2002). The first is assigned to the family Rhynchonellida (wedge shaped test): Notosaria nigricans [Tegulorhynchia of Fleming (1953)], while the other three are assigned to the family Terebratulida ('hole-borer' or lamp shells): Neothyris sp., Calloria inconspicua [Waltonia genus renamed; G. Cooper and Lee (1993)], and Magasella sanguinea. This latter species was not observed in this study.

\section{Mollusca}

Many authors have previously studied the mollusc assemblage of the Hautawa Shellbed and the faunal list is extensive (A. Beu, 1969; A. G. Beu, G. H. Browne, \& T. L. Grant-Taylor, 1981; Fleming, 1953; Mclntyre, 2002). Table 1.6.1 highlights some species found in the lower Hautawa Shellbed and implications of the four most significant are discussed below.

Zygochlamys delicatula is known as the primary criterion and marker of the basal Nukumaruan Stage in the Whanganui Basin (R. Cooper \& Agterberg, 2004). Elsewhere, Crassostrea ingens is part of a distinctive Mangapanian age faunal assemblage which 
also includes Phialopecten thomsoni. The occurrence of Zygochlamys delicatula alongside Crassostrea ingens implies that the giant oyster survived into the very earliest Nukumaruan [Table 1.6.1, pg. 26]. In contrast to Zygochlamys delicatula which is found in modern water of up to $600 \mathrm{~m}$, Crassostrea ingens is seen in many Pliocene age limestones of near-shore and sub-tidal environments. It likely occupied a semi-estuarine, near-shore niche which Crassostrea virginica does today (A. Beu \& Maxwell, 1990).

Another genus of importance in the Hautawa Shellbed is Phialopecten due to a change in species known to occur at this time. One significant aspect of this species change, to the terminal species Phialopecten triphooki, is that Phialopecten thomsoni is part of the prior 'warm water' assemblage (A. G. Beu, 1995; Mclntyre, 2002). Hence, the extinction of Phialopecten thomsoni is another example of how the Hautawa Shellbed occurs at a climatically significant point in the Whanganui Basin stratigraphy. Phialopecten triphooki is also limited in age range to the early part of the Nukumaruan Stage (A. G. Beu, 1995).

\subsubsection{Microfauna}

\section{Foraminifera}

A sample of Hautawa Shellbed collected in the Mangawhero River section at Parapara Road (today known as SH4) and was summarised by Hornibrook (1981). This sample contained Zygochlamys delicatula alongside a number of specific foraminifera. The key microfossils noted by Hornibrook (1981) include:

1. Globorotalia crassula and dominantly dextrally coiling Globorotalia crassaformis

2. Globorotalia tosaensis, Globorotalia puncticuloides, and Globorotalia inflata

3. Abundant Notorotalia zelandica

The presence of Globorotalia crassula, together with dextrally coiling Globorotalia crassaformis, is considered to be a key marker for the boundary from Mangapanian to Nukumaruan age deep marine sediments so their presence in the Hautawa Shellbed, and younger sediments overlying it, is critical (R. Cooper \& Agterberg, 2004; Hornibrook, 1981). The benthic foraminifera Notorotalia zelandica has an uncertain first appearance date (FAD) due to its form being transitional with Notorotalia kingmai so is considered less appropriate as a basal Nukumaruan marker (Hornibrook, 1981). 
Jenkins (1971), suggests that the limited foraminiferal faunal assemblage in the Hautawa Shellbed is the result of shallow water deposition. They noted that a sample from the type section of the Hautawan Shellbed contains dominant dextrally coiling Globorotalia pachyderma (=Neogloboquadrina pachyderma) which is consistent with cooler water masses.

Pollen

Samples collected by Mildenhall (1978) taken from within and down to $3.5 \mathrm{~m}$ below the Hautawa Shellbed, from a locality near the type section, were found to contain a poorly preserved, water sorted, and species poor pollen assemblage (Mildenhall, 1978). The samples were dominated by saccate pollen and resistant spores. Samples also contained abundant fern spores, pollen of podocarps and beech, and Ascarina lucida (a species of endemic small tree or forest shrub) (Mildenhall, 1978). Samples from beneath the shellbed, contained abundant Dacrydium cupressinum (rimu) pollen.

\subsubsection{Faunal assemblage summary}

Fleming (1953) describes the Hautawa Shellbed as containing "abundant molluscan and brachiopod shells of which Chlamys, Tegulorhynchia (of a rather irregular growth-form), and Barbatia, are conspicuous" (pg. 130). The Chlamys species to which Fleming refers to may be either Zygochlamys delicatula or Talochlamys gemmulata (A. Beu \& Maxwell, 1990), as both of the species are notable within the shellbed. The brachiopod genera Tegulorhynchia was renamed Notosaria (D. Lee, 1978).

Fleming (1953) goes on to describe the depositional setting of the Hautawa Shellbed as developed through bottom currents acting to concentrated benthic fauna and coarser sediment within deposits of silt and mud. This forms the basis of a 'hard-bottom' environment containing the abandoned shells of infaunal species such as Zenatia and Dosinia greyi. Fleming comments that their habitat comprises muddy substrata. Therefore, the general assemblage, including Chlamys (= Zygochlamys and Talochlamys), Barbatia, Venericardia, Pullastra, Dosinula, Turritellidae, and Brachiopoda, found in the Hautawa lived on this 'hard-bottom' surface. It is noted that this faunal association is not known from in New Zealand seas, and Fleming concludes that the Hautawa likely contains a combination of several associations. 


\section{CHAPTER ONE}

Rocks of early Nukumaruan age in the Hawke's Bay region were found to contain Zygochlamys delicatula alongside sub-Antarctic crab Jacquinotia edwardsii (A. Beu et al., 1981). The presence of these two species at temperate latitudes is thought to have been the result of migration following cooling of sea temperatures due to extensive global glaciation at this time. 


\section{CHAPTER TWO \\ MACROFAUNA METHODOLOGY}

\subsection{INTRODUCTION}

Figure 2.2.1 outlines the structure of this chapter and Chapter 3. Chapter 2 focuses on the methodology for data collection used for macrofauna and the localities visited. Chapter 3 will continue from this and explain the analysis carried out on the macrofaunal dataset.

The field work consisted of the documentation of detailed measured sections at key locations. Taphonomic information was recorded alongside standard sedimentary data in situ through the strata and compiled to produce augmented high-resolution measured sections.

The Hautawa Shellbed in many places was a recrystallized coquina limestone, precluding the standard approach of bulk sample collecting followed by identification and faunal analysis in the laboratory. An approach suggested by Patzkowsky and Holland (2012) is designed to overcome this by in situ faunal counting. Consecutive measured sections are constructed along strike in order to identify temporal and spatial variation within the unit of interest (Patzkowsky \& Holland, 2012). Their approach requires the division of a unit into "time-environment cells" (pg. 214) in order to sample the primary environmental gradient. As the Hautawa Shellbed is already known to be a condensed unit (Naish \& Kamp, 1995), equal sized 'cells' or 'boxes' of $15 \mathrm{~cm}$ thickness were used consistently throughout the unit at all sites. Taphonomic attributes, after Hendy et al. (2006), were described alongside the faunal content in each cell. This method overcame the issue of the fragile and fragmentary nature of fauna contained in the Hautawa Shellbed.

The key requirement for this method to be successful is nearly continuous and 'good' quality outcrop exposures. 'Good' meaning where weathering has caused macrofauna to be well exposed on the surface, with the matrix being worn back. Figure 
Figure 2.1.1: Structure of Chapter 2 and Chapter 3.

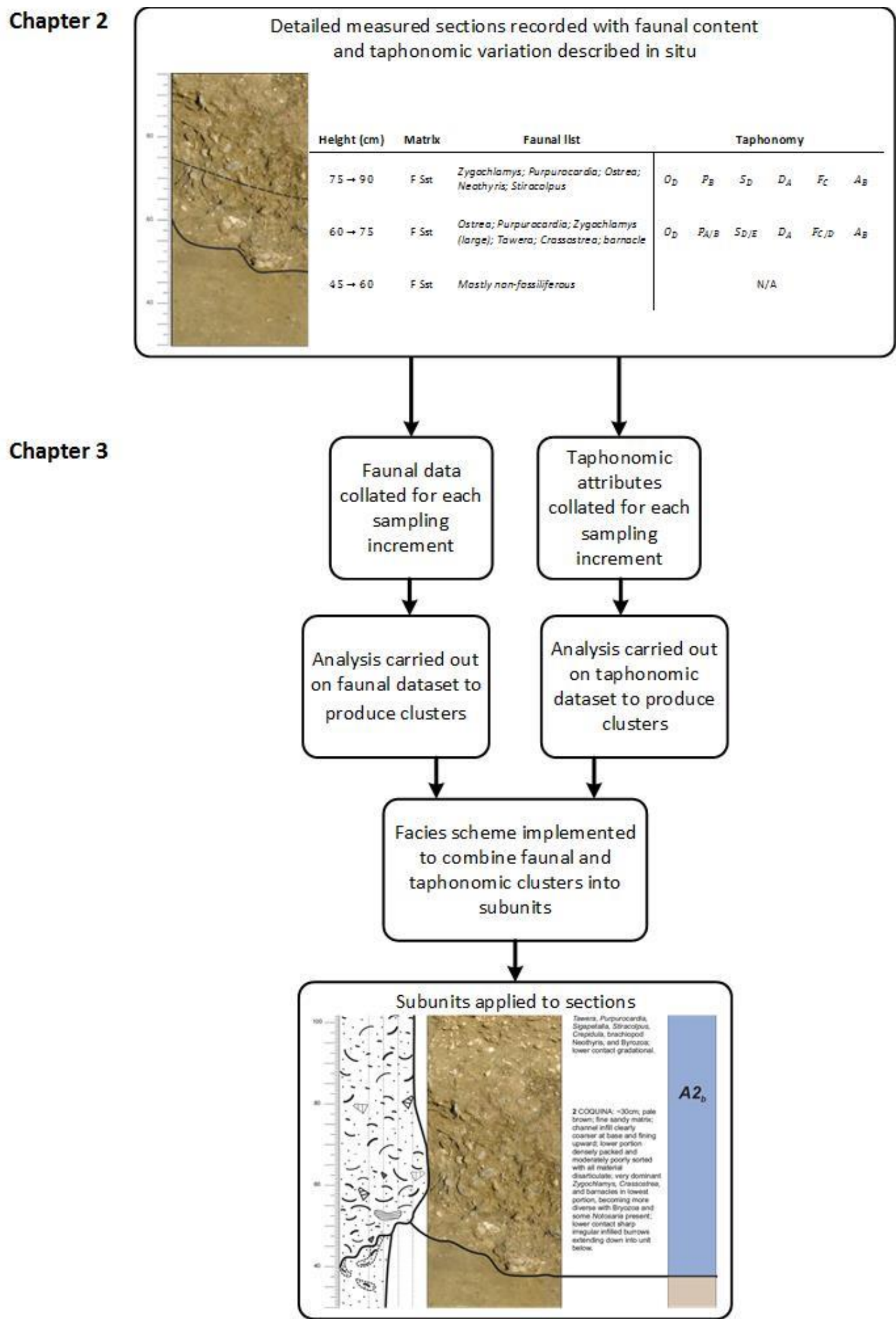


2.1.2 compares examples of a 'good' vs a 'poor' exposure quality as encountered during this study. The distance along West Road between the two exposures shown is just less than $20 \mathrm{~m}$. At most localities the units are not cemented into a hard outcrop exposure, but this is a significant issue for the limestone at Colenso Station. The fragility and synsedimentary fragmentation of most fauna is a noteworthy difficulty with assessment of coquina limestones of this type.

Figure 2.1.2: Comparison of exposure qualities present at West Road.

Good quality outcrop exposure (lower Section A) vs poor quality exposure (lower section B).

Arrows each mark $15 \mathrm{~cm}$ 'cells' in each section.

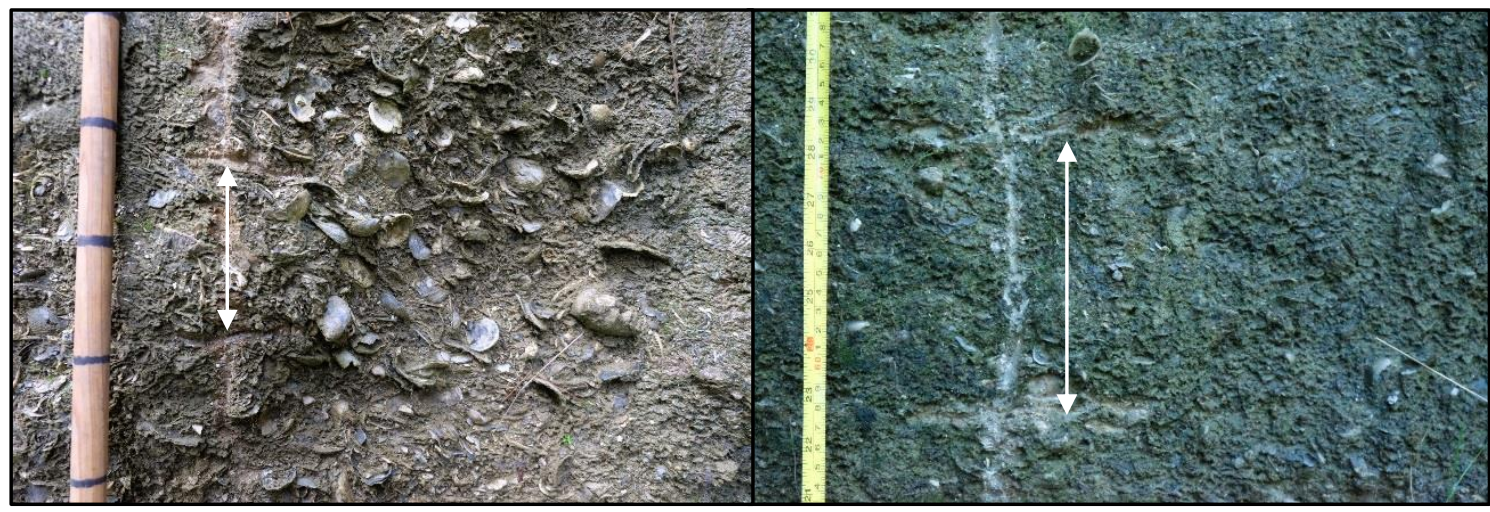

At each locality across the Whanganui Basin, generally one or two sites were chosen for detailed measuring. Sites were primarily chosen on exposure quality as described above.

\subsection{SECTION MEASURING}

\subsubsection{Outcrop measurement}

As outlined in Figure 2.2.1, data was collected in the field following standard measured section techniques (Andrews, 1982) and augmented with in situ documentation of faunal and taphonomic content of the shellbed in regular cells (Hendy et al., 2006; Patzkowsky \& Holland, 2012). The process in Figure 2.2.1 was followed to collect quantitative information in situ by describing the outcrop in $15 \mathrm{~cm}$ increments. 
Figure 2.2.1: Flow diagram of field approach to compile quantitative biostratigraphic data of taphonomy alongside traditional stratigraphic.

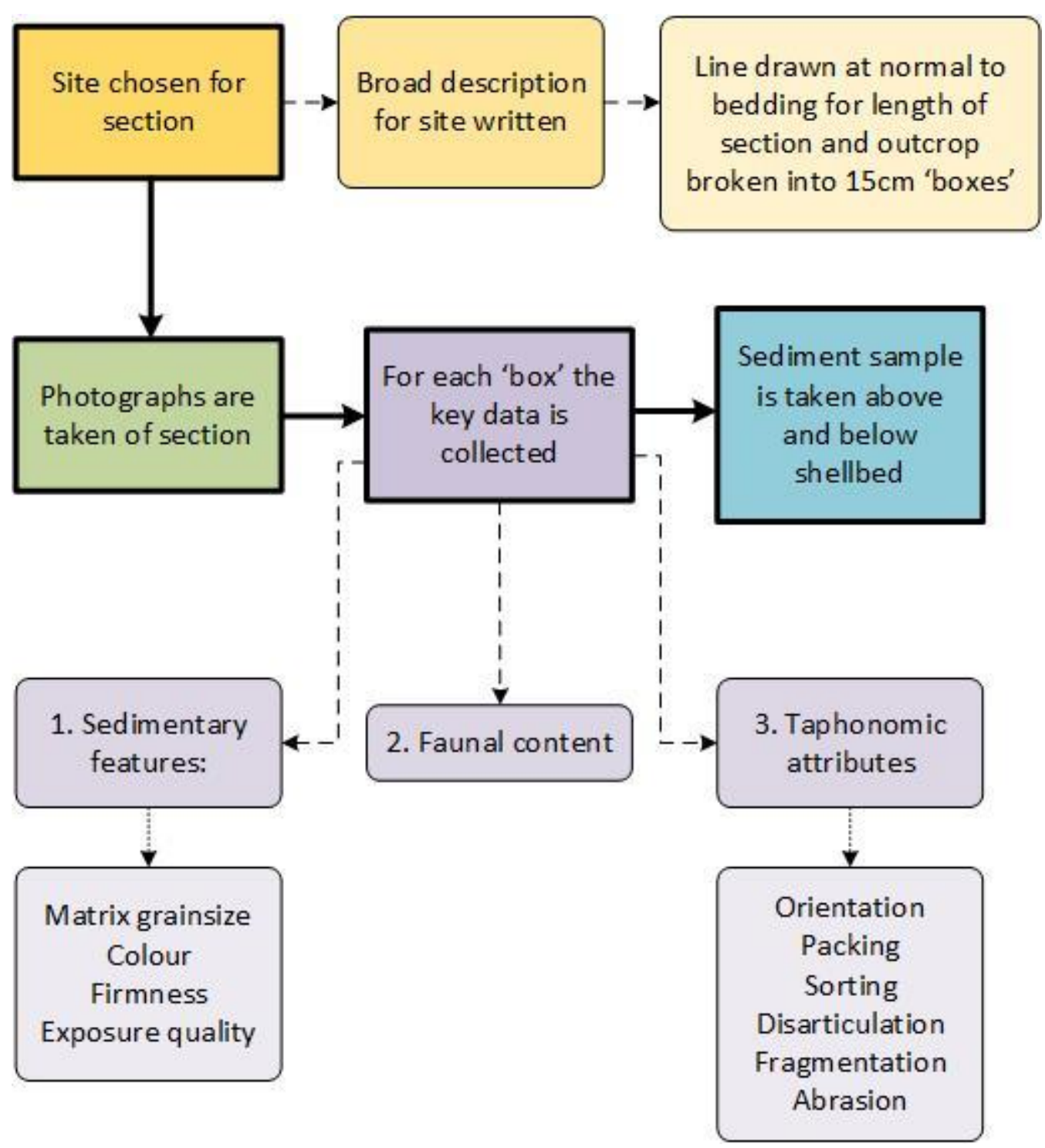


The purpose of this approach is the capability of describing high resolution sedimentology and taphonomy of a lithology where bulk sampling is hindered. This may be due to a range of issues. For example, firmness, cementation, or fragility of specimens all make sampling for macro-fauna for later laboratory-based identification and description impractical. The measured sections documented are included as Enclosures with this thesis and summarized in the Appendix [Table A.7.1].

\section{Taphonomy}

Taphonomy is defined as "the study of processes of preservation and how they affect information in the fossil record" (pg. 105) (Behrensmeyer \& Kidwell, 1985). Condensed shellbeds, such as the Hautawa Shellbed, are rich in taphonomic data which can

Table 2.2.1: Taphonomic attribute classification scheme after Hendy, Kamp, and Vonk (2006).

CHARACTERISTICS

\begin{tabular}{|c|c|c|c|c|c|c|}
\hline & & A & B & C & D & $\mathbf{E}$ \\
\hline & & Concave up & Convex up & In situ & Mixed & N/A \\
\hline Orientation & 0 & $\begin{array}{l}\text { Concave-up ori- } \\
\text { ented skeletal } \\
\text { material domi- } \\
\text { nant }\end{array}$ & $\begin{array}{l}\text { Convex-up ori- } \\
\text { ented skeletal } \\
\text { material domi- } \\
\text { nant }\end{array}$ & $\begin{array}{l}\text { Most skeletal } \\
\text { material oriented } \\
\text { in life position }\end{array}$ & $\begin{array}{l}\text { Mixed concave- } \\
\text { up, convex-up and } \\
\text { perpendicular ori- } \\
\text { ented }\end{array}$ & $\begin{array}{l}\text { Orientation } \\
\text { cannot be } \\
\text { determined }\end{array}$ \\
\hline \multirow[b]{2}{*}{ Packing density } & \multirow[b]{2}{*}{$\mathbf{P}$} & Very dense & Dense & Moderate & Loose & Dispersed \\
\hline & & $\begin{array}{l}\text { Skeletal mate- } \\
\text { rial is bioclast } \\
\text { supported }\end{array}$ & $\begin{array}{l}\text { Most skeletal } \\
\text { material is bio- } \\
\text { clast supported }\end{array}$ & $\begin{array}{l}\text { Skeletal material } \\
\text { may be bioclast } \\
\text { of matrix sup- } \\
\text { ported }\end{array}$ & $\begin{array}{l}\text { Skeletal material } \\
\text { is matrix sup- } \\
\text { ported, matrix is } \\
\text { dominant over bi- } \\
\text { oclasts }\end{array}$ & $\begin{array}{l}\text { Skeletal ma- } \\
\text { terial is iso- } \\
\text { lated within } \\
\text { matrix }\end{array}$ \\
\hline \multirow[b]{2}{*}{ Sorting size } & \multirow[b]{2}{*}{$\mathbf{S}$} & Very good & Good & Moderate & Poor & Very poor \\
\hline & & $\begin{array}{l}\text { Skeletal mate- } \\
\text { rial very well } \\
\text { sorted }\end{array}$ & $\begin{array}{l}\text { Skeletal mate- } \\
\text { rial well sorted }\end{array}$ & $\begin{array}{l}\text { Skeletal material } \\
\text { moderately well } \\
\text { sorted }\end{array}$ & $\begin{array}{l}\text { Skeletal material } \\
\text { poorly sorted }\end{array}$ & $\begin{array}{l}\text { Skeletal } \\
\text { material is } \\
\text { very poorly } \\
\text { sorted }\end{array}$ \\
\hline \multirow[b]{2}{*}{ Disarticulation } & \multirow[b]{2}{*}{ D } & Very high & High & Moderate & Some & Conjoined \\
\hline & & $\begin{array}{l}\text { All skeletal ma- } \\
\text { terial disarticu- } \\
\text { lated }\end{array}$ & $\begin{array}{l}\text { Disarticulated } \\
\text { skeletal material } \\
\text { dominant }\end{array}$ & $\begin{array}{l}\text { Mixture of disar- } \\
\text { ticulated and ar- } \\
\text { ticulated skeletal } \\
\text { material }\end{array}$ & $\begin{array}{l}\text { Articulated skele- } \\
\text { tal material domi- } \\
\text { nant }\end{array}$ & $\begin{array}{l}\text { All skeletal } \\
\text { material } \\
\text { articulated }\end{array}$ \\
\hline \multirow[b]{2}{*}{ Fragmentation } & \multirow[b]{2}{*}{$\mathbf{F}$} & Very high & High & Moderate & Poor & None \\
\hline & & $\begin{array}{l}\text { All skeletal } \\
\text { material } \\
\text { fragmented }\end{array}$ & $\begin{array}{l}\text { Fragmented } \\
\text { skeletal material } \\
\text { dominant }\end{array}$ & $\begin{array}{l}\text { Mixture of } \\
\text { fragmented and } \\
\text { complete skele- } \\
\text { tal material }\end{array}$ & $\begin{array}{l}\text { Complete skeletal } \\
\text { material domi- } \\
\text { nant, fragmented } \\
\text { material uncom- } \\
\text { mon }\end{array}$ & $\begin{array}{l}\text { All skeletal } \\
\text { material } \\
\text { complete }\end{array}$ \\
\hline \multirow[b]{2}{*}{ Abrasion } & \multirow[b]{2}{*}{ A } & High & Some & None & N/A & \\
\hline & & $\begin{array}{l}\text { Most skeletal } \\
\text { material } \\
\text { abraded }\end{array}$ & $\begin{array}{l}\text { Abraded } \\
\text { skeletal material } \\
\text { uncommon }\end{array}$ & $\begin{array}{l}\text { No abraded } \\
\text { skeletal material }\end{array}$ & $\begin{array}{l}\text { Abrasion cannot } \\
\text { be determined }\end{array}$ & \\
\hline
\end{tabular}


augment other paleoenvironmental indicators observed during field work. Key taphonomic attributes are: disarticulation, fragmentation, packing density, size sorting, orientation, abrasion, dissolution, cementation and bioerosion. They form a graded classification scheme (reduced form in Table 2.2.1). Each attribute is regarded as semiquantitative. Bioerosion and cementation are excluded due to difficulty applying these characteristics in the case of the Hautawa Shellbed. Bioerosion was not distinguishable at surface exposures of fauna. Cementation was not a significant factor in the central Whanganui Basin but present only in the base of the limestone unit at Colenso Station.

Figure 2.2.2: Taphonomic description of basal Hautawa Shellbed at Ridge Road; Mangamahu. JEGE_14A.

Section measured at left edge of photo in centimetres.

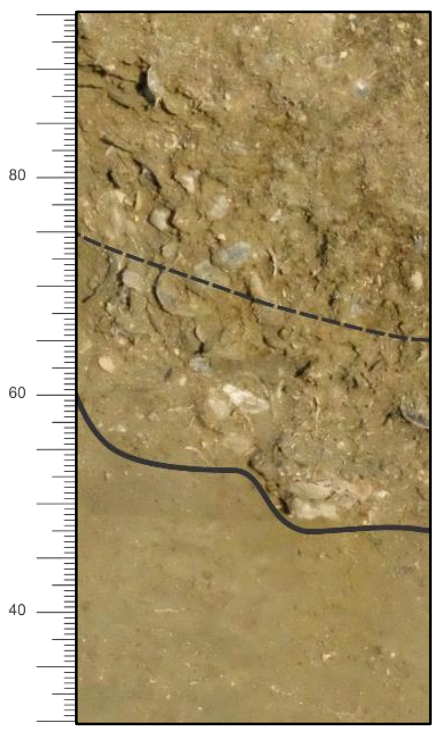

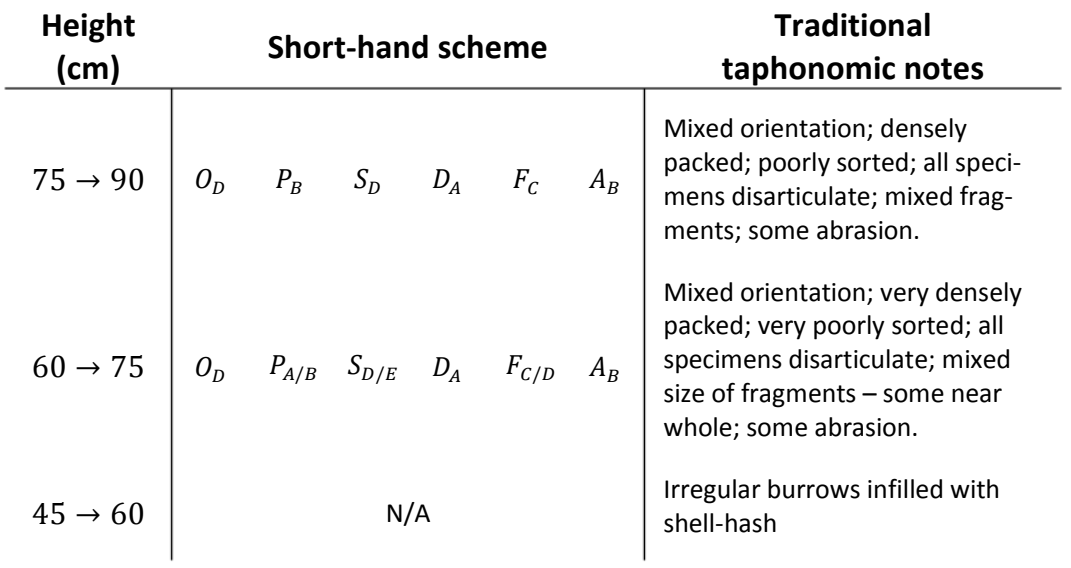

Table 2.2.2: Exemplary field notes for basal Hautawa Shellbed at Ridge Road; Mangamahu.

\begin{tabular}{|c|c|c|c|c|c|c|c|c|}
\hline Height $(\mathrm{cm})$ & Matrix & Faunal list & & & Tapr & nom & & \\
\hline $75 \rightarrow 90$ & F Sst & $\begin{array}{l}\text { Zygochlamys; Purpurocardia; Ostrea; } \\
\text { Neothyris; Stiracolpus }\end{array}$ & $O_{D}$ & $P_{B}$ & $S_{D}$ & $D_{A}$ & $F_{C}$ & $A_{B}$ \\
\hline $60 \rightarrow 75$ & F Sst & $\begin{array}{l}\text { Ostrea; Purpurocardia; Zygochlamys } \\
\text { (large); Tawera; Crassostrea; barnacle }\end{array}$ & $O_{D}$ & $P_{A / B}$ & $S_{D / E}$ & $D_{A}$ & $F_{C / D}$ & $A_{B}$ \\
\hline $45 \rightarrow 60$ & F Sst & Mostly non-fossiliferous & \multicolumn{6}{|c|}{ N/A } \\
\hline
\end{tabular}


Figure 2.2.2 demonstrates how this field technique is designed to increase the detail and repeatability of the taphonomic attribute recording while reducing note writing volume. For example, as in the cell for $75 \rightarrow 90 \mathrm{~cm}$ [Fig. 2.2.2], in order to describe that there is a 'mixed size of fragments, with some near whole' the note would be written as: $F_{C / D}$. This is achieved by using Table 2.2.1 as a matrix with semi-quantitative range columns $\mathrm{A}$ to $\mathrm{E}$ and rows for each attribute. $F$ relates to the row for 'fragmentation' and $C / D$ to columns $C$ and D i.e. 'moderate' to 'poor'. Therefore, every segment of strata can be quickly and concisely taphonomically described and recorded along with notes of the faunal assemblage present within the sampling increment. Though the taphonomic descriptions were only applied to the Shellbed itself and not to the encompassing units.

\subsubsection{Sampling of macro-fauna}

This study aimed to not take macro-faunal samples and the data set relies on field identifications only. A few bulk samples were taken of particularly well-preserved macrofossil specimens and have been identified with collaboration from Dr Alan Beu, GNS Science.

\subsection{RESEARCH SITES}

\subsubsection{Central Whanganui Basin - Hautawa Shellbed}

Research has been conducted on the Hautawa Shellbed by many previous authors and their site locations are collated in Table 2.3.1 with coordinates in New Zealand Transverse Mercator projection (NZTM).

Three sites were chosen in the central Whanganui Basin for this study and the location data for these sites are in Table 2.3.2:

1. Ridge Road [blue dot; Fig. 2.3.1],

2. Old Hautawa Road [green dot; Fig. 2.3.1], and

3. West Road [yellow dot; Fig. 2.3.1].

These sites were selected based on a number of characteristics. Firstly, chosen by the quality of outcrop seen at the site. Secondly, how accessible the site was with 
equipment was important for selection. Lastly, the geographic position of the site relative to others in order to achieve reasonable spread of sites across the known localities was also significant. Outcrop quality is particularly critical in this study as the majority of analyses relies on collection of in situ data. Exposures on Ridge Road and West Road are included by Fleming (1953) as outcrops of the Hautawa Shellbed. These sites were also previously documented by McIntyre in his study of Mangapanian age strata of the Whanganui Basin (McIntyre, 2002). However, his work on the Hautawa Shellbed by was done at a lower resolution than in this study. Here sediments immediately above and below the Hautawa Shellbed have also been examined incrementally.

\section{Ridge Road, Matawhitia Station, Mangamahu}

The Hautawa Shellbed outcrops persist alongside Ridge Road for a number of kilometres. It is exposed best near a small cutting (JEGE_14) [Fig. 2.3.2]. Weathering of the outcrop has cleaned back the Shellbed matrix so the fossil materials are clearly visible at the surface.

Gentle undulations of the basal contact are distinctive at this site. The contact included a number of distinctive channel cut troughs with localised condensed basal layers of larger fossils. The Ridge Road Section A [Enclosure 1] was conducted beside one large trough containing distinctive Crassostrea ingens and nearby Phialopecten thomsoni. The basal contact is well exposed at both sections JEGE_14A and JEGE_14B, but due to the upper contact's gradational nature in this region, the shellbed was not able to be assessed in a continuous section. The upper contact is obscured in both sections here, with the shellbed disappearing beneath soil and long grass. Due to this, the total thickness measured is a minimum but this site was considered sufficiently exposed to be valuable in this study.

The measured section at this site was constructed as a composite. The lowermost $2.2 \mathrm{~m}$ was exposed at the site measured at Ridge Road (JEGE_14B) [Enclosure 1, Section $B]$, and approximately $1.5 \mathrm{~m}$ was exposed beside the road nearby with the upper contact visible, gradational over $0.5 \mathrm{~m}$. This is consistent with the findings of Mclntyre (2002). McIntyre noted that the Hautawa Shellbed has a gradational upper contact with the underlying Tuha Siltstone, and a thickness of 2.5 to $3 \mathrm{~m}$ was recorded. 
Table 2.3.1: Site locations from other sources and coordinates converted to New Zealand Transverse Mercator (NZTM).

\begin{tabular}{|c|c|c|c|}
\hline & Source & Site name & NZTM \\
\hline \multirow{6}{*}{$\begin{array}{l}\text { Central } \\
\text { Whanganui Basin } \\
\text { Hautawa Shellbed }\end{array}$} & Fleming (1953) & $\begin{array}{l}\text { Ridge Road; } \\
\text { N.Z.G.S. } 4355\end{array}$ & $1792655 \mathrm{E}, 5595112 \mathrm{~N}$ \\
\hline & Mclntyre (2002) & Ridge Road & $1804268 \mathrm{E}, 5591709 \mathrm{~N}$ \\
\hline & Fleming (1953) & $\begin{array}{l}\text { West Road; } \\
\text { N.Z.G.S. } 3096\end{array}$ & $\begin{array}{c}1821418 \text { E, } 5586623 \mathrm{~N} \\
\text { [pink dot, Fig. 2.3.4] }\end{array}$ \\
\hline & \multirow{2}{*}{ A. Beu (2001) } & \multirow{2}{*}{ West Road } & $\begin{array}{l}1822676 \mathrm{E}, 5586614 \mathrm{~N} \\
\text { [orange dot, Fig. 2.3.4] }\end{array}$ \\
\hline & & & $\begin{array}{l}1821776 \mathrm{E}, 5586614 \mathrm{~N} \\
\text { [brown dot, Fig. 2.3.4] }\end{array}$ \\
\hline & McIntyre (2002) & West Road & $1822476 \mathrm{E}, 5586714 \mathrm{~N}$ \\
\hline \multirow{2}{*}{$\begin{array}{l}\text { Limestones near } \\
\text { Ruahine Range }\end{array}$} & $\begin{array}{l}\text { A. Beu, G. Browne, and } \\
\text { T. Grant-Taylor (1981) }\end{array}$ & Te Rakaunuiakura & $1870547 \mathrm{E}, 5609226 \mathrm{~N}$ \\
\hline & Milne (1968) & $\begin{array}{l}\text { Limestone bluff, } \\
\text { Cone Creek }\end{array}$ & $1856455 \mathrm{E}, 5569994 \mathrm{~N}$ \\
\hline
\end{tabular}

Table 2.3.2: Site locations studied in this thesis and coordinates in New Zealand Transverse Mercator (NZTM). Sites plotted in Figure 2.3.1.

\begin{tabular}{|c|c|c|c|c|}
\hline & Site name & Section name & Site code & NZTM \\
\hline \multirow{6}{*}{$\begin{array}{l}\text { Central } \\
\text { Whanganui Basin } \\
\text { Hautawa Shellbed }\end{array}$} & \multirow{3}{*}{$\begin{array}{l}\text { Ridge Road, } \\
\text { Mangamahu, } \\
\text { Whangaehu Valley }\end{array}$} & \multirow{3}{*}{$\begin{array}{l}\text { Ridge Road } \\
\text { [blue dot; Fig. 2.3.1] }\end{array}$} & JEGE_14A & $1804245 \mathrm{E}, 5591745 \mathrm{~N}$ \\
\hline & & & JEGE_14B & $1804206 \mathrm{E}, 5591721 \mathrm{~N}$ \\
\hline & & & JEGE_14C & $1803883 \mathrm{E}, 5591394 \mathrm{~N}$ \\
\hline & $\begin{array}{l}\text { Otiwhiti Station, } \\
\text { Turakina Valley }\end{array}$ & $\begin{array}{l}\text { Old Hautawa Road } \\
\text { [green dot; Fig. 2.3.1] }\end{array}$ & JEGE_5 & 1818346 E, $5586812 \mathrm{~N}$ \\
\hline & West Road, upper & West Road & JEGE_15A & $1822251 \mathrm{E}, 5586646 \mathrm{~N}$ \\
\hline & Hautawa Stream & [yellow dot; Fig. 2.3.1] & JEGE_15B & $1822239 \mathrm{E}, 5586632 \mathrm{~N}$ \\
\hline \multirow{2}{*}{$\begin{array}{l}\text { Limestones near } \\
\text { Ruahine Range }\end{array}$} & $\begin{array}{l}\text { Makino Stream } \\
\text { tributary, Colenso } \\
\text { Station }\end{array}$ & $\begin{array}{l}\text { Colenso Station } \\
\text { [orange dot; Fig. 2.3.1] }\end{array}$ & JEGE_8 & 1859947 E, $5599892 \mathrm{~N}$ \\
\hline & $\begin{array}{l}\text { Cone Creek, near } \\
\text { Sixtus Lodge, Apiti }\end{array}$ & $\begin{array}{l}\text { Cone Creek } \\
\text { [red dot; Fig. 2.3.1] }\end{array}$ & JEGE_16 & $1856509 \mathrm{E}, 5569918 \mathrm{~N}$ \\
\hline
\end{tabular}




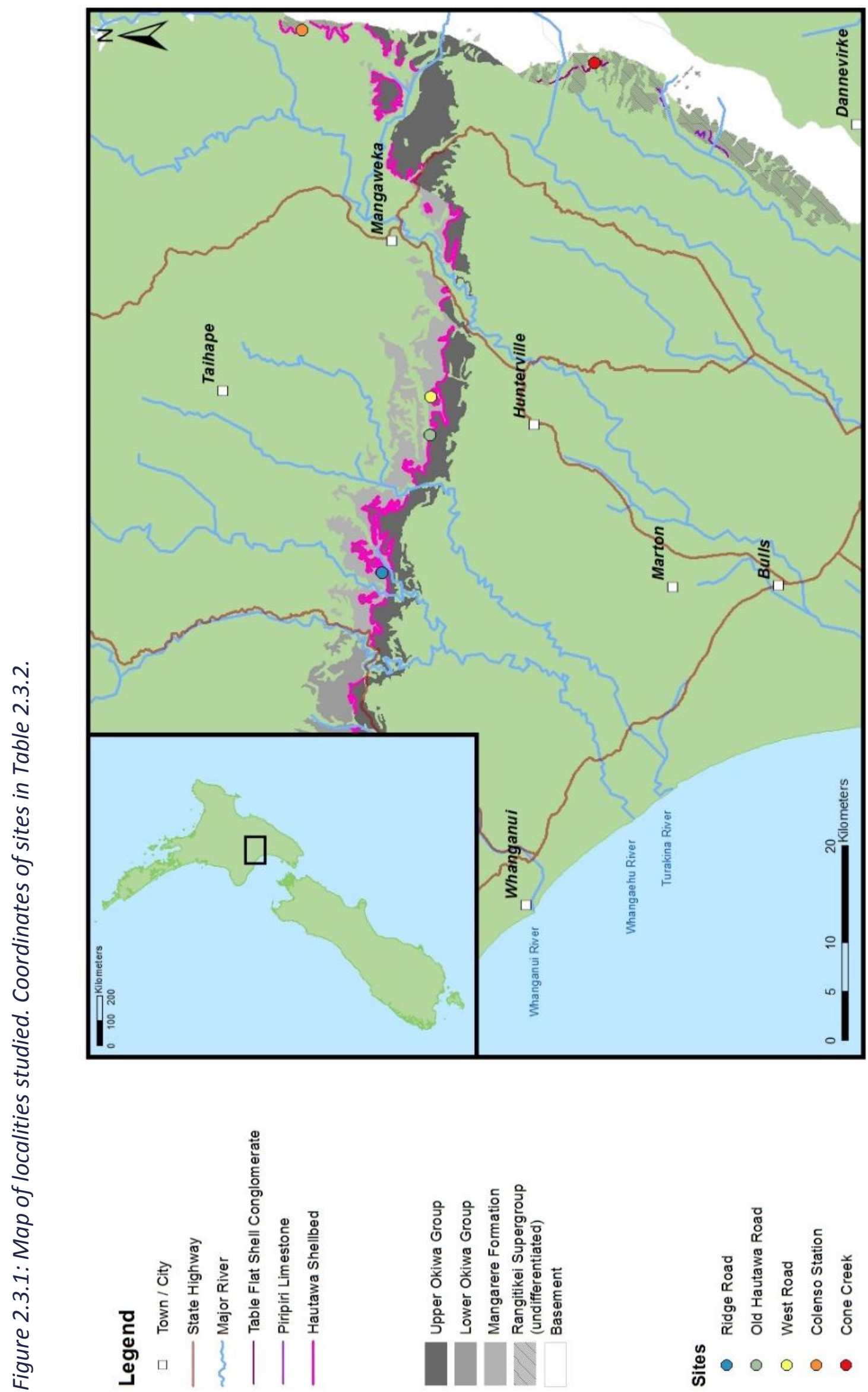


Figure 2.3.2: Photo of Ridge Road main site on Matawhitia Station. Scale $=1.5 \mathrm{~m}$

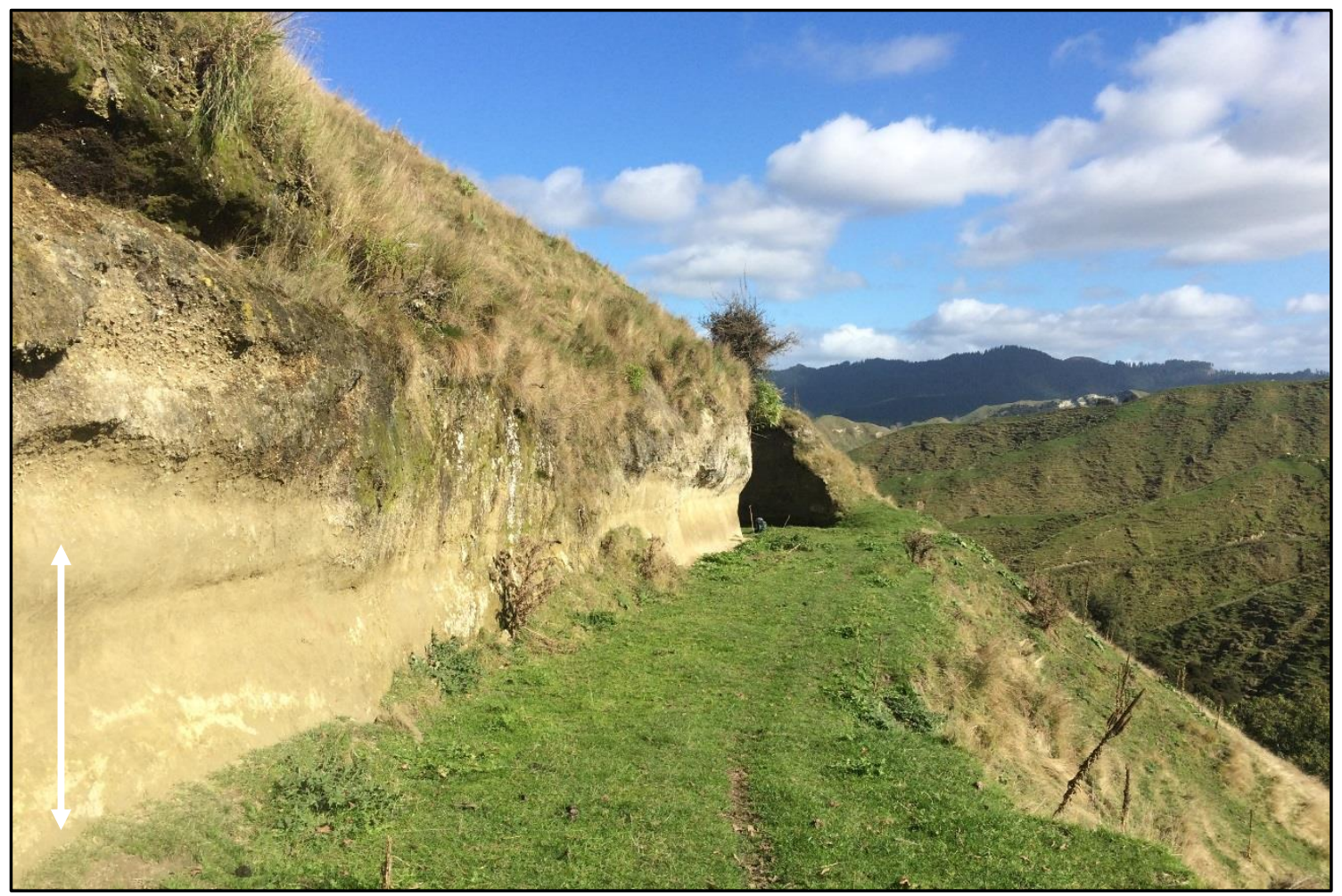

Figure 2.3.3: Photo of Old Hautawa Road site on Otiwhiti Station. Scale $=1.5 \mathrm{~m}$

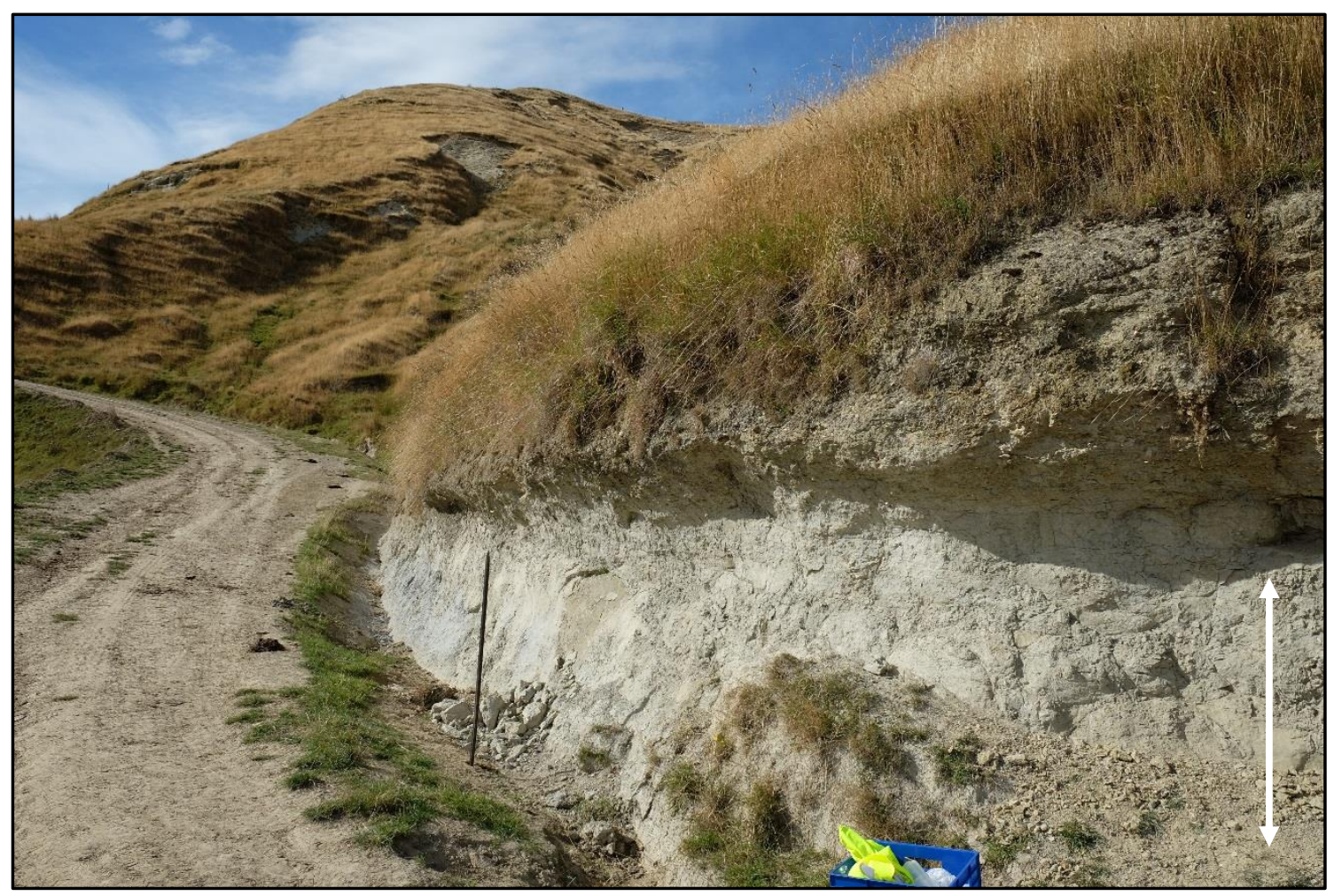


Sediment samples were collected at this site for foraminifera. One sample is from beneath Section B (sample 015) and the other from along the road where the gradational upper contact was observed (sample 014).

\section{Old Hautawa Road, lower Hautawa Stream; Otiwhiti Station}

Here the Shellbed outcrop subdivides into in three distinctive portions: a lower shellbed, an intra-shellbed siltstone, and an upper shellbed [green dot; Fig. 2.3.1 and 2.3.4]. The lower shellbed is very poorly exposed here in the shallow gutter at the road side, but can be seen in a small, steep gully carved by a culvert drain. In contrast, the central siltstone and upper shellbed units are nicely exposed at the road side [Fig. 2.3.3]. This site of the Hautawa Shellbed has not been described previously, but the outcrop fits the trace plotted by QMAP [pink line; Fig. 2.3.4].

Four samples were taken and assessed for foraminiferal content and these are from: 1) the basal sandy unit below the lower shellbed (sample 002), 2) the lowest part of the intra-shellbed siltstone (sample 001), 3) the sandy silt unit directly above the upper shellbed (sample 006), and 4) the blue-grey siltstone at the top of the outcrop (sample 005). These samples are referred to as collected at Otiwhiti Station, on Old Hautawa Road.

West Road, upper Hautawa Stream; Otiwhiti Station

The exact position of the type-section for the Hautawa Shellbed along Old Hautawa Road is unclear from the literature but outcrops can be observed along the roadside for over a kilometre. Fleming (1953) locality N.Z.G.S. 3096 is considered here to be an informal type locality for the Hautawa Shellbed [pink dot; Fig. 2.3.4].

Beu (2001) suggested that an appropriate location for SSP (Standard Section and Point) for the base of the Nukumaruan Stage would be found along Old Hautawa Road [between brown and orange dots; Fig. 2.3.4], but this has yet to be formally accepted into the New Zealand Geological Timescale (R. Cooper \& Agterberg, 2004; Hollis et al., 2010). Sections A and B at the West Road locality [yellow dot; Fig. 2.3.1 and 2.3.4] are positioned centrally within the region suggested for the SSP by A. Beu (2001). The portion of outcrop selected to be studied here was chosen as it contained a complete exposure: a silty unit below the shell bed proper, the entire shellbed, and a siltstone unit 
above. The outcrop is nicely exposed and continuous beside the road here for over 50 $\mathrm{m}$ at this location [Fig. 2.2.5].

Three samples were collected at this site for foraminiferal assessment: one from the siltstone overlying the shellbed (sample 003) at section $B$, and one each from the siltstone below section A (sample 004), and Section B (sample 007); respectively.

Figure 2.3.4: Topographic map of West Road locations

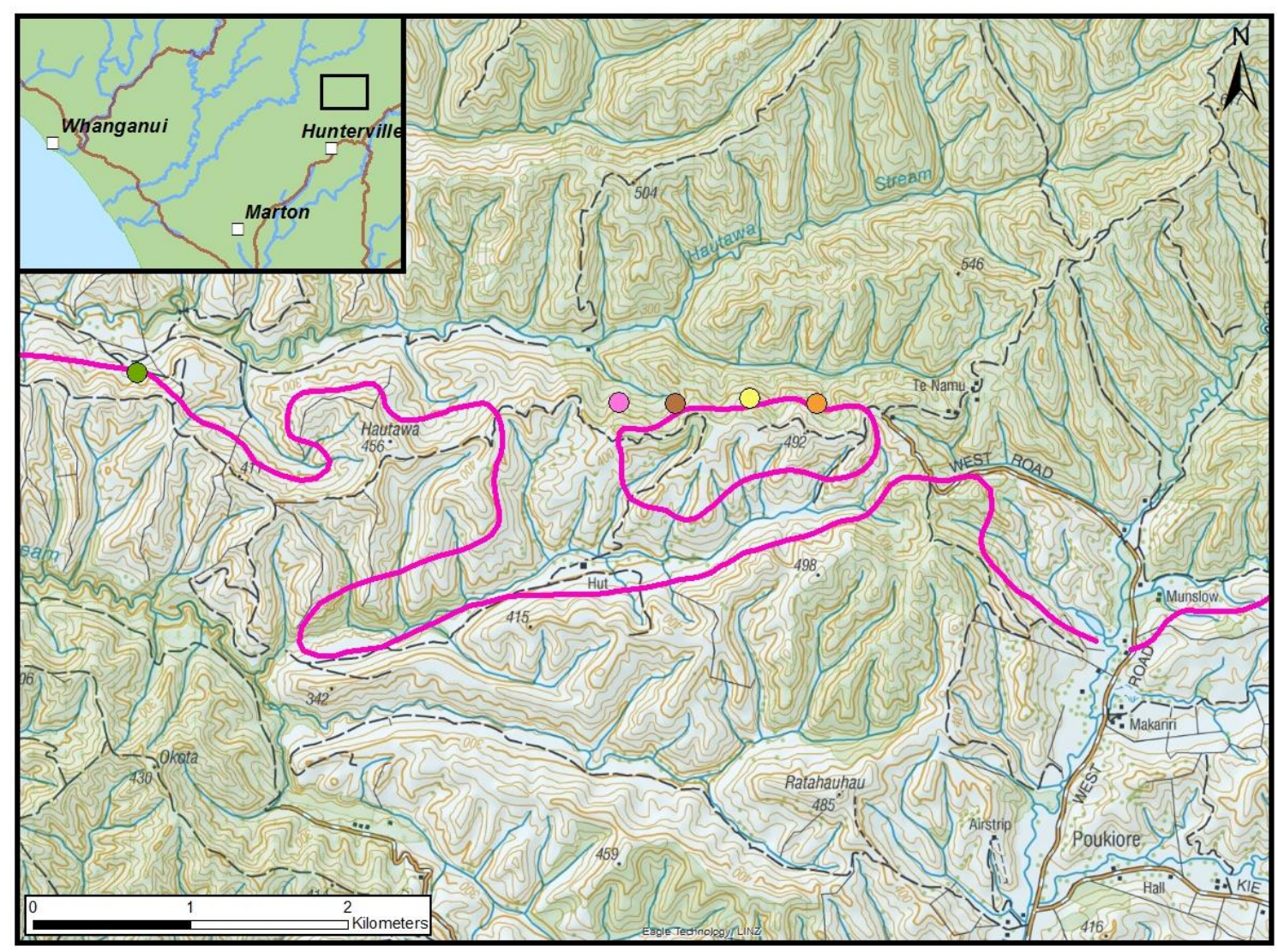

\footnotetext{
Sites

$\square \quad$ Town / City

N.Z.G.S. 3096 (Fleming, 1953)

- State Highway

- Eastern (Beu, 2001)

Major River

- Western (Beu, 2001)

o West Road

- Old Hautawa Road

Hautawa Shellbed
} 
Figure 2.3.5: Photo of West Road site during measuring of section $A$ at site JEGE_14. Scale $=1.5 \mathrm{~m}$

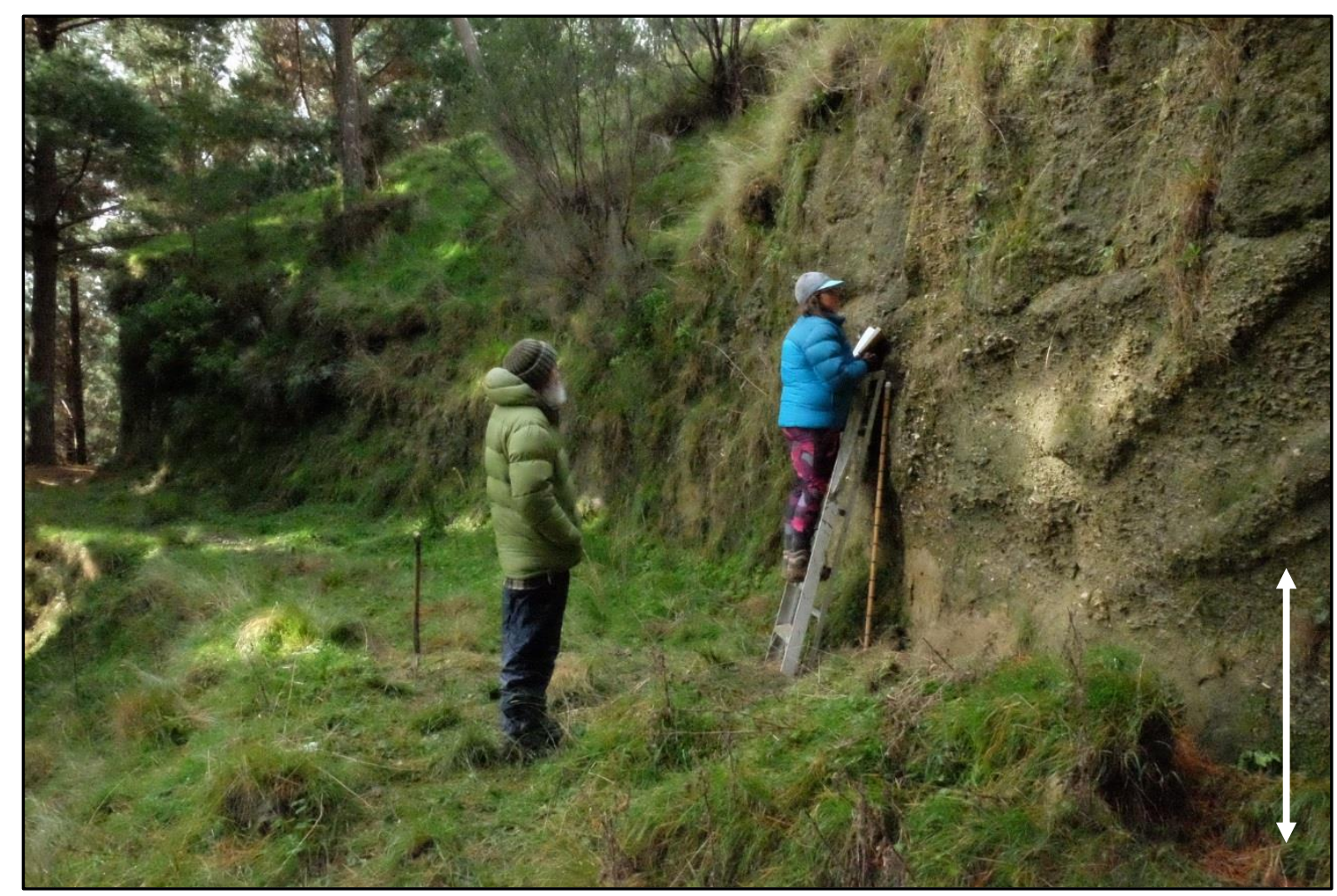

\subsubsection{Eastern Margin - Limestones proximal to Ruahine Range}

Limestones on the eastern margin of Whanganui Basin were not assessed in high resolution increments as with the central region.

The relationship between the Hautawa Shellbed in the central Whanganui Basin and the outcrops visited east of the Rangitikei valley is unclear as the Nukumaruan age sedimentary units vary to the east. The Hautawa Shellbed and basal Nukumaruan sediment can be traced on QMAP east from the Rangitikei River until it abuts the greywacke basement Ruahine range (J. Lee et al., 2011; Townsend, Kamp, \& Vonk, 2008). Nukumaruan strata is then found only sporadically both to the north and south of this latitude due to exposure being controlled here by erosion and uplift of the central range.

To the south, strata is poorly constrained in QMAP and possible Nukumaruan rocks are plotted as 'Rangitikei Supergroup (undifferentiated)' in the Pohangina Valley and near the Manawatu Saddle region [hatched grey unit; Fig. 2.3.1]. To the north, Nukumaruan age sediment is briefly exposed at gradually higher elevations. The northern 
sediments mapped in QMAP are likely correlatives rather than actual examples of Hautawa Shellbed [pink line, Fig. 2.3.1]. Two particular locations to the north are of interest: Colenso Station (investigated here; ca. 700m AMSL) and Te Rakaunuiakura (ca. $1300 \mathrm{~m}$ AMSL).

The outcrops at Colenso Station [orange dot; Fig. 2.3.1], analysed for the first time in detail here, were first located by GNS Science during mapping conducted for the publication of QMAP of the Hawke's Bay (J. Lee et al., 2011). Particular note was taken of the thick pebbly limestone outcrops here due to the presence of numerous specimens of the suggested Nukumaruan Stage indicator scallop Zygochlamys delicatula (Raine et al., 2015).

Four sediment samples were collected and assessed from Colenso Station: sample 010 (below), sample 011 (above), sample 012 (directly below limestone in burrows), and sample 013 (near the top in the gradational region).

Te Rakaunuiakura is included in research published by Beu, Browne, and GrantTaylor (1981). The presence of Nukumaruan age strata here is based upon the presence of a single Zygochlamys delicatula valve. The valve comes from a thin capping of cemented coquina at the north side of Te Rakaunuiakura (A. G. Beu et al., 1981). This site is considered by the authors to be the stratigraphically highest point in the local area and is the highest elevation of any Nukumaruan strata in the Whanganui Basin.

One location to the south of the central basin sites was also visited in the upper Pohangina Valley [red dot, Fig 2.3.1]. Previous work in the region near Cone Creek has suggested that basal Nukumaruan strata are present. For example, the Table Flat Shell Conglomerate which was noted to contain Zygochlamys delicatula along with Crassostrea ingens and Phialopecten triphooki (Milne, 1968). The latter two species are generally considered to be elsewhere Mangapanian Stage restricted, but are known to occur together for the last time during the very earliest Nukumaruan Stage. 


\section{CHAPTER THREE}

\section{ANALYSIS OF MACROFAUNAL DATA}

\subsection{INTRODUCTION}

This section describes the analysis used to investigate the macrofaunal and taphonomic dataset collected during field work as described in Figure 2.2.1, pg. 41.

Analysis of palaeontological data recorded directly from outcrops and in sediment samples was completed using the free statistical computing software $R$ ( $R$ Core Team, 2017). In particular, the packages stats (Team, 2002), dplyr (Wickham \& Francois, 2015), tidyr (Wickham, 2016b), vegan (Oksanen et al., 2007), PresenceAbsence (Freeman, 2012), factoextra (Kassambara \& Mundt, 2017), rgl (Adler et al., 2018), devtools (Wickham \& Chang, 2016), FactoMineR (Lê, Josse, \& Husson, 2008), mclust (Fraley \& Raftery, 2006), and ggplot2 (Wickham, 2016a) were used in the analysis and data processing. Complete code is included in the Appendix. Explanation of the analysis methodology is divided into macrofaunal and foraminiferal datasets here in Chapter 3 and in Chapter 5; respectively.

\subsection{ANALYSIS OF MACROFAUNAL DATASET}

\subsubsection{Data analysis methods}

Analysis of the macrofaunal, described in situ, data was carried out with no consideration of a sample's position within a section. I.e. every $15 \mathrm{~cm}$ 'unit' described in the Hautawa Shellbed was compared to all others without any a priori implications being drawn due to the position of any 'unit' within the Shellbed.

Due to poor continuous exposure at the majority of outcrops, data collection was mostly limited to the binary form of $1 \mathrm{~s}$ and 0 s representing presence and absence of species. While it is statistically stronger to be able to investigate faunal change with percentage abundance data, binary data are also appropriate (Borcard, Gillet, \& Legendre, 
2011). To make integration easier the taphonomic data were converted to binary rather than their native categorical form.

The raw data were cleaned as outlined in the $\mathrm{R}$ code included in the Appendix. Data collected in an incomplete section (JEGE_13) were removed. It was noted that recorded data for the 8th sample cell in section JEGE_14A was missing. To overcome this, data was duplicated from the 7th cell. In particular for macro-faunal data, any species with less than 5 occurrences in the entire dataset are considered rare and were removed from this analysis to avoid noise. This is because rare species, which may in fact have environmental significance, may have been missed in many cells and are likely to be under sampled in the dataset. Therefore, they are omitted to avoid sampling bias or noise in the data set. Talochlamys was also removed as present in $61 \%$ of samples (30 of 49) and is not useful for determining the paleoenvironmental or useful age. If left in, the very high occurrence rate will bias the data into groups of 'with' and 'without' Talochlamys which is not useful for investigating paleoenvironment.

Data analysis follows the methods recommend by Borcard et al. (2011). Both the faunal and taphonomic data sets were first standardised using function decostand from the vegan package (Oksanen et al., 2007). The purpose of this is to change a raw collection of measurements that are not comparable and normalise each set of measurements such that they then can be compared. The standardisation used was 'normalize' which makes the sum of squares equal to one. This is also known as a 'chord transformation' (Borcard et al., 2011). This transformation removes influences of productivity on an assemblage because the total abundance in a sample is controlled by the total productivity (Borcard et al., 2011).

This pre-processing produces a set $\left(y_{i}\{i=1 \ldots N\}\right)$ where each raw set of points $\left(x_{i}\{i=1 \ldots N\}\right)$ in a dataset has been transformed with respect to the mean $(\bar{x})$ of those points. This is achieved by calculating:

$$
y_{i}=\frac{x_{i}}{\sqrt{\sum_{i=1}^{N}\left(x_{i}-\bar{x}\right)^{2}}}
$$


Hence, a normalised value $\left(y_{i}\right)$ is calculated for each data value $\left(x_{i}\right)$ by dividing each by the square root of the sum of squares. This means now that if the sum of squares was calculated for the normalised values $\left(y_{i}\{i=1 \ldots N\}\right)$ it would then be equal to one. If this is calculated for all sets of measurements, their influence on samples can now be investigated and compared directly even when the raw data sets were of different magnitudes.

An example of a simple application of this is if a set of measurements recorded from some leaves needed to be compared, but the data was measurements of length, thickness, and width for each sampled leaf. In this case, it is likely that two of the measurements (length and width) are going to be an order of magnitude larger than the other (thickness), so they cannot be compared directly. By conducting a chord transformation prior to other analysis, it becomes possible to compare measurements even though the raw data had very different magnitudes.

The faunal data, once standardized, are clustered using k-means cluster analysis. The cascadeKM function from the vegan package produced the plot in Figure 3.2.1 by acting as a wrapper for the function kmeans in the package stats (Oksanen et al., 2007; Team, 2002). k-means clustering initially has the number of clusters to be found within

Figure 3.2.1: Plot produced by cascadeKM in order to exhibit how the local maximum ssi criterion is reached when four clusters are found within the faunal dataset.
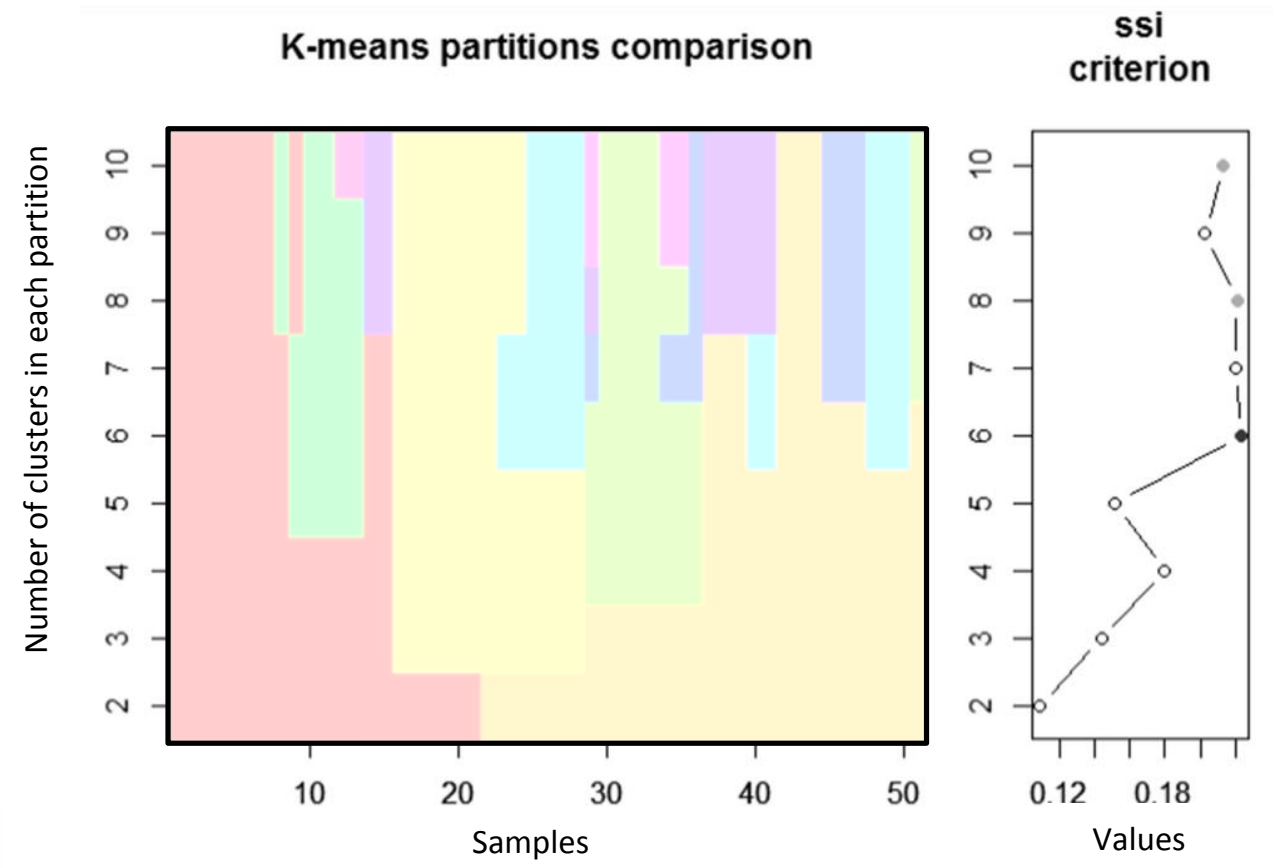
a data set assigned. Each number on the x-axis of the plot represents each 'box' or 'cell' recorded in situ, here they are called 'samples' [Fig. 3.2.1]. There is no significance to the order of these samples. The $y$-axis of the plot in Figure 3.2.1 counts how many clusters are calculated for each partition of the dataset. For example, "2" on the y-axis of the plot equates to samples being divided into either the 'yellow' or the 'red' cluster [Fig. 3.2.1]. The colours shown in Figure 3.2.1 are completely independent of those used in Figures 3.2.2-3.2.6 described below.

The usefulness of the cascadeKM function is that it can iteratively calculate the partitioning of samples into clusters. Here the random number of starting configurations for each value of ' $k$ ' was 10,000 ("iter $=10000$ "). This function also calculates the 'simple structure index' (ssi) criterion (a test statistic) for each number of partitions. The ssi is suggested by the authors of cascadeKM to be best suited to finding the maximum value near or at the optimal number of clusters within the dataset (Oksanen et al., 2007). In the case of the macrofauna, the ssi criterion suggests that the optimal number of clusters may be six, but a parsimonious approach selects the lower local maxima at four. This is done here to reduce how many clusters the dataset is partitioned into as at higher values of $k(=6,8,10)$ the ssi value is equal and the initial four main clusters are just being divided up. This choice of four clusters is further supported by the comparison of mclust and kmeans presented in the Appendix.

To better understand the driving fauna behind each cluster, Principal Component Analysis (PCA) was applied to the dataset using the function princomp ( $\mathrm{R}$ Core Team, 2002). This allows the biplots shown in Figures 3.2.2-3.2.6 to be produced using fviz_pca_biplot from the package factoextra (Kassambara \& Mundt, 2017). The axes of biplots are the principal components (PCs) of the faunal dataset. The species which control the position of a sample within clusters can then be read off these biplots. Relationships between data points and a priori k-means clusters in PC space can also be observed. The k-means cluster to which each sampled outcrop portion belongs has be noted on the corresponding measured section sheet included as enclosures. 


\subsubsection{Observed faunal clusters}

A convex hull of a set is the smallest convex polygon which encloses all points in that set. Here they are used in the biplots to emphasise the region of the sample spread compared to the $95 \%$ confidence ellipse plotted for the clusters [Figs. 3.2.2-3.2.6]. This is important for showing the differences between similar clusters. For example, in Figure 3.2.3 the ellipses for faunal clusters 1 and 3 clearly overlap but their convex hulls are nearly completely distinct when plotted on PC2 vs PC3.

The four clusters found within the faunal dataset are plotted showing sample positions in principal component space [Figs. 3.2.2-3.2.6]. Figures 3.2.2-3.2.4 show the positions of samples in PC space along with labels for each sample. Figures 3.2.5 and 3.2.6 display samples (points) in faunal PC

The following plots (Figures 3.2.2-3.2.4) are in PC space of the faunal sample set. Each cluster is displayed with: convex hulls, 95\% ellipses, and the cluster means (which equate to the centre of the ellipses) are shown by the larger symbols

Figure 3.2.2: Plot of PC1 and PC2 with all four clusters shown. $40.3 \%$ of the variation in the faunal dataset is accounted for by these axes.

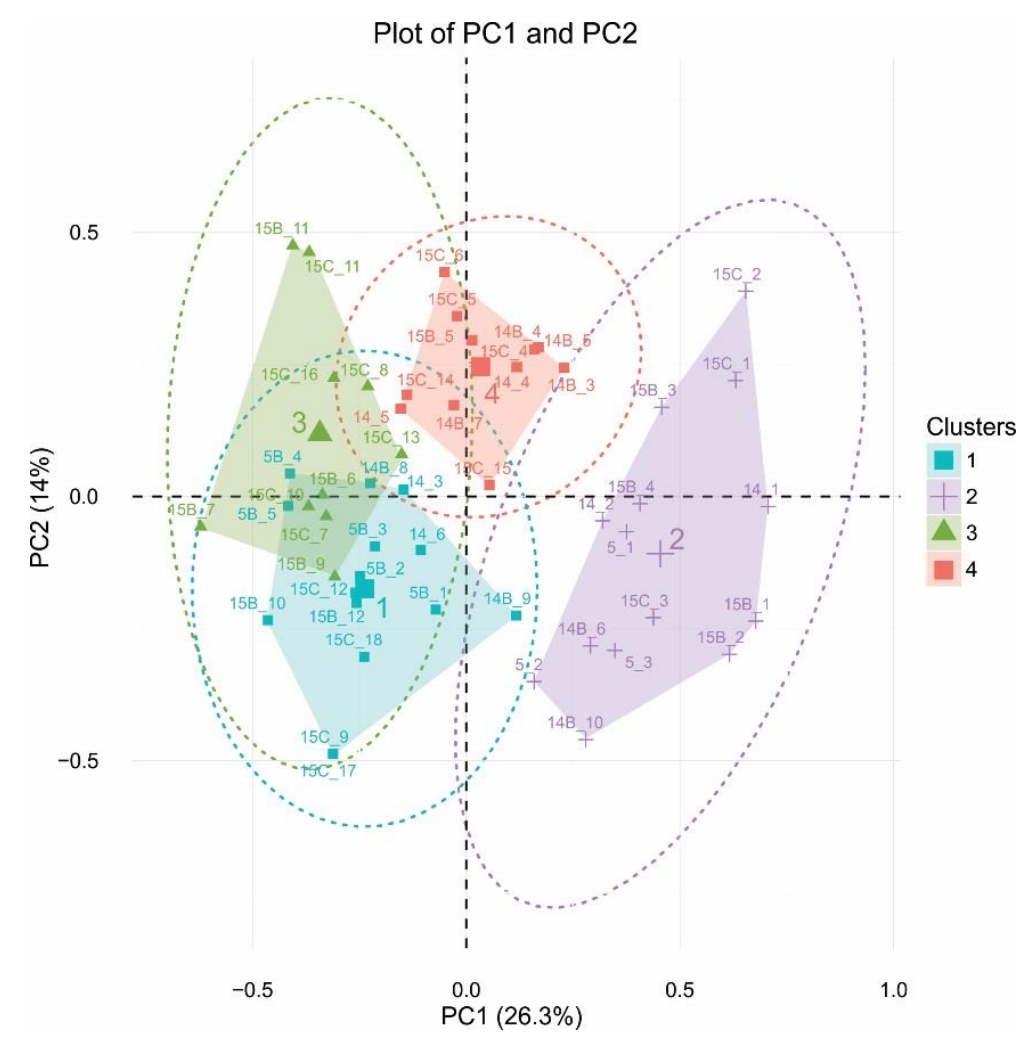


Figure 3.2.4: Plot of PC2 and PC3 with all four clusters shown. $24.9 \%$ of the variation in the faunal dataset is accounted for by these axes.

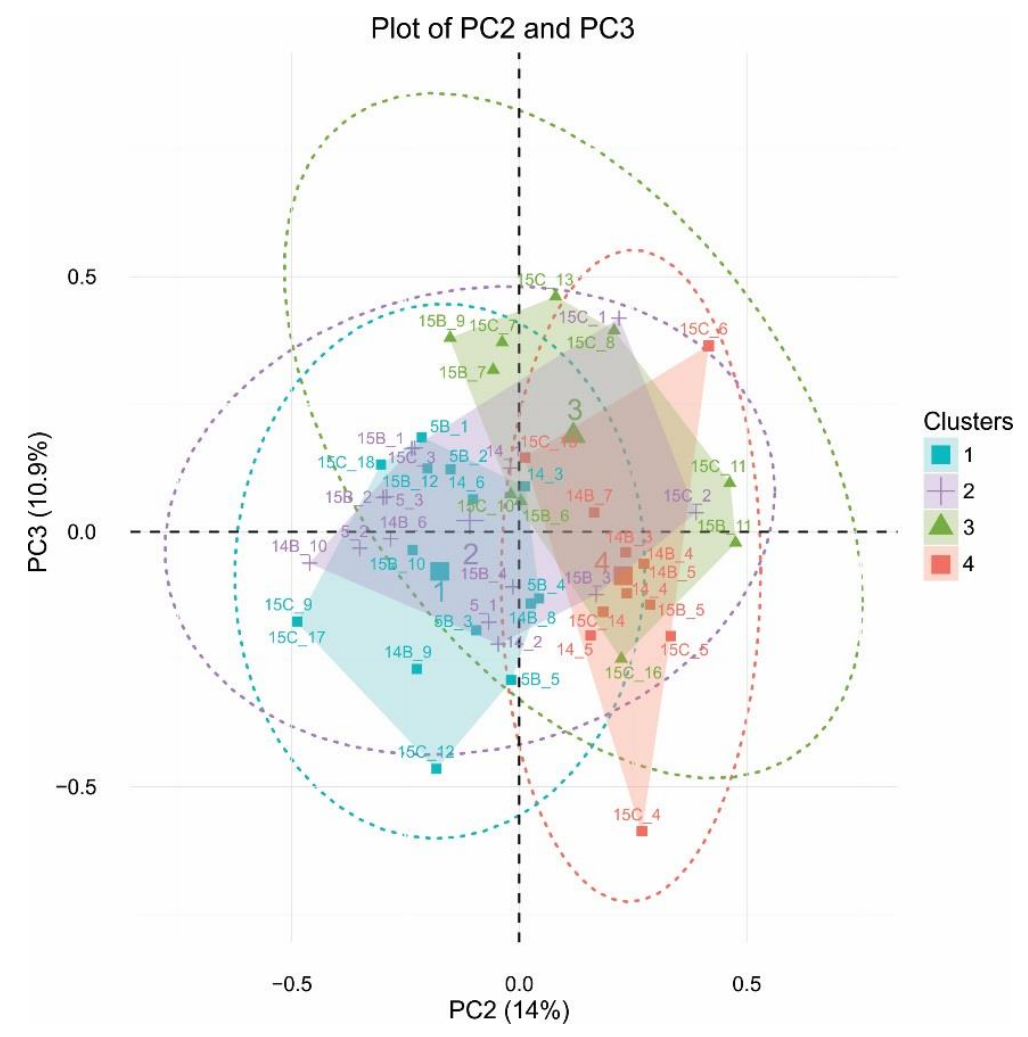

Figure 3.2.3: Plot of PC1 and PC3 with all four clusters shown. $37.2 \%$ of the variation in the faunal dataset is accounted for by these axes.

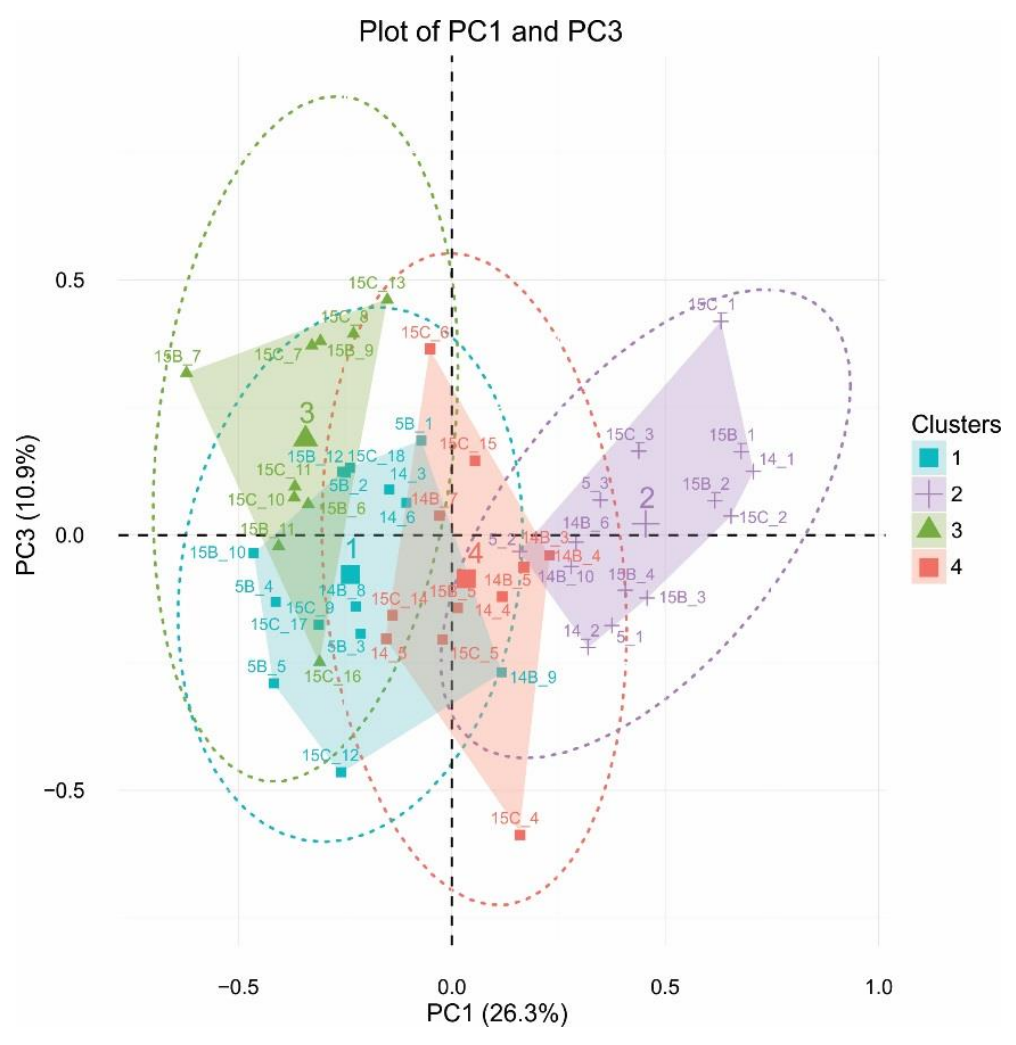




\section{CHAPTER THREE}

Figure 3.2.5: Bi-plot of complete faunal dataset showing clusters, samples (points), and genera (the variable vectors).

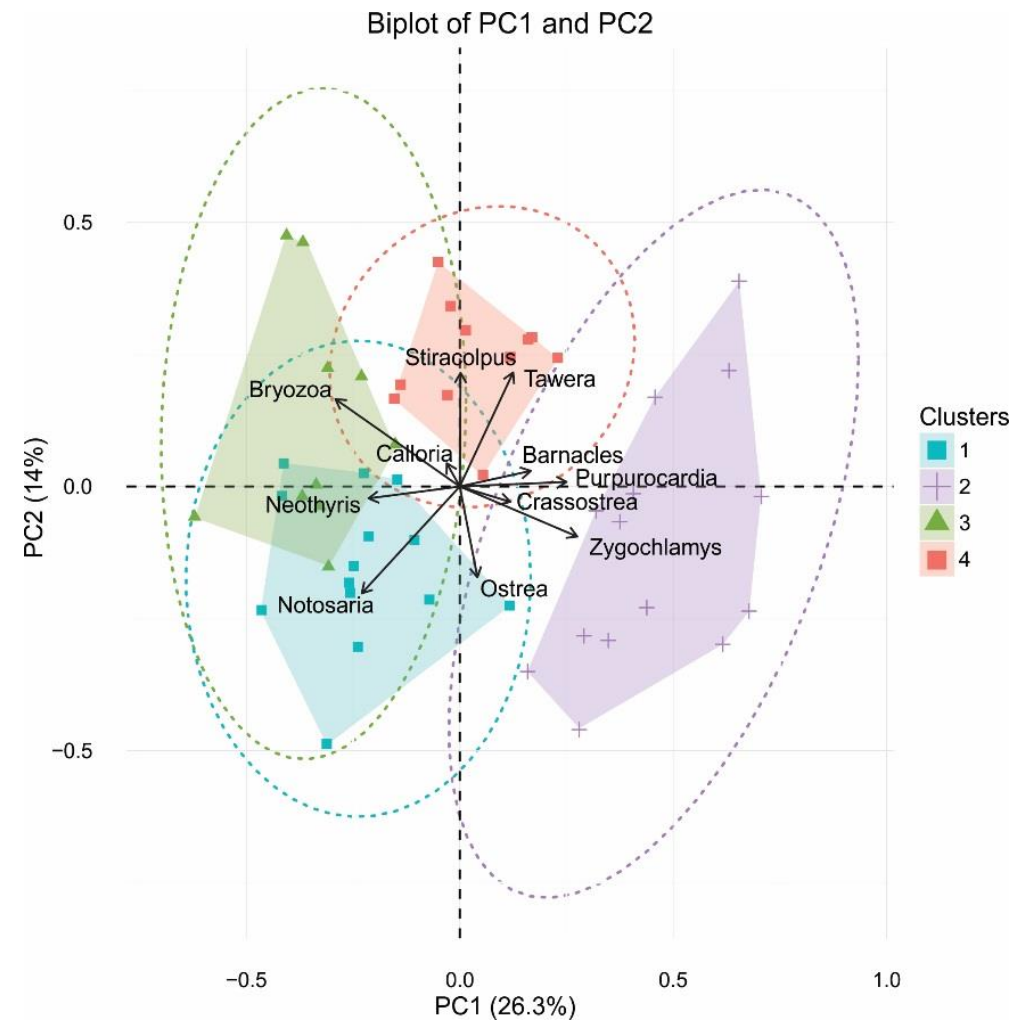

Figure 3.2.6: Bi-plot of faunal data from clusters 1 and 3 showing clusters, samples (points), and genera (the variable vectors).

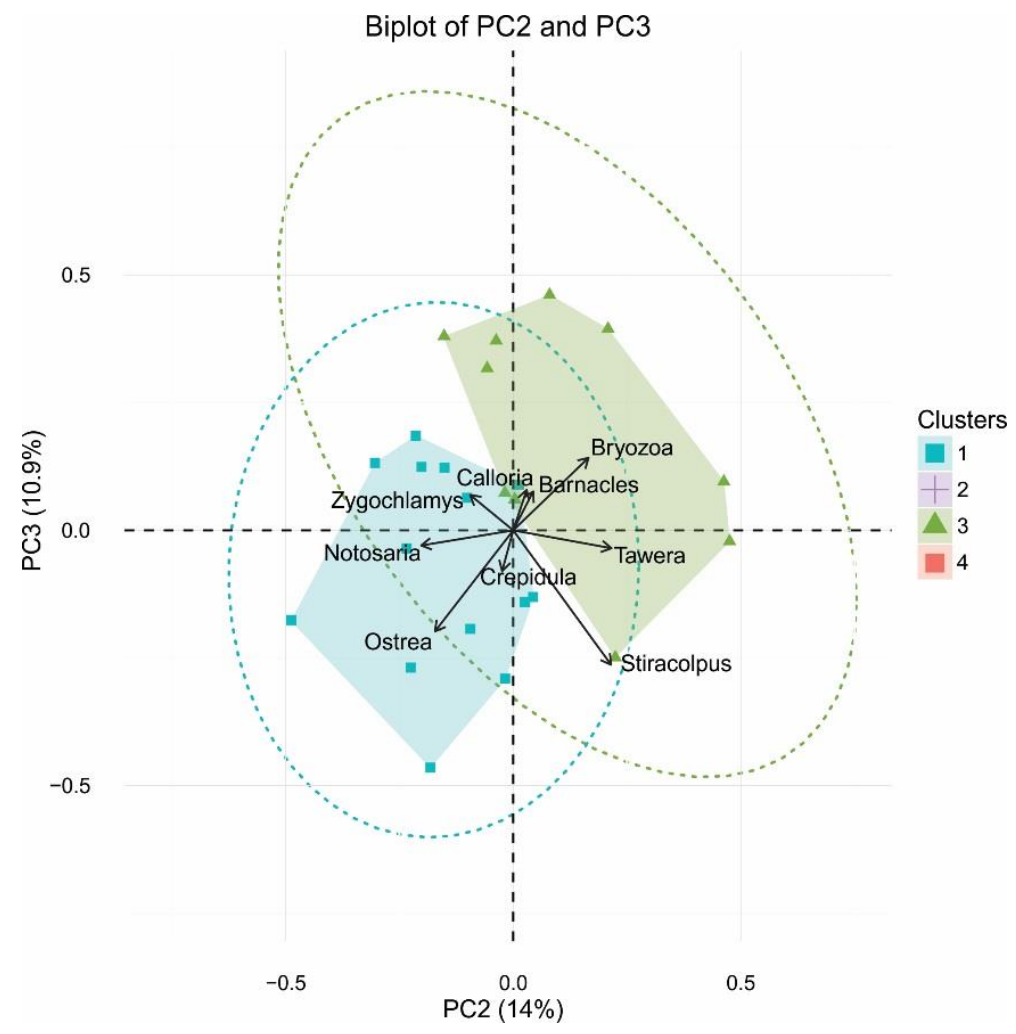


space and the controlling genera (variable vectors) - i.e. they are bi-plots.

PC1 accounts for $26.3 \%$, PC2 $14 \%$, and $10.9 \%$ of the total variation in the faunal assemblage dataset. Clusters 2 and Cluster 4 are dispersed when plotted on PCs 1 and 2, but Clusters 1 and 3 do not distribute as clearly on this first biplot [Fig. 3.2.2]. Clusters 1 and 3 are more easily distinguished on PC2 vs PC3 [Fig. 3.2.3].

\section{Faunal Cluster 1}

The bi-plots show that the controlling genera for Cluster 1 are: Ostrea, Notosaria, and Neothyris, with minor influence from Zygochlamys [blue; Figs. 3.2.2-3.2.6]. Cluster 1 mostly has scores of $<0$ on both PC1 and PC2 [Fig. 3.2.2], and distributes on PC3 [Fig. 3.2.2]. While distinct from Clusters 2 and 4 , there is some overlap between Cluster 1 and Cluster 3. The key contrasting genera between them appears to be the presence, in Cluster 3 of Bryozoa and perhaps Tawera [Fig. 3.2.5]

\section{Faunal Cluster 2}

Shown in purple [Figs. 3.2.2-3.2.6], Cluster 2 is strongly driven by the presence of Zygochlamys, Purpurocardia, and Crassostrea, along with the presence of barnacles and possibly Ostrea. There also appears to be a clear dominance of lower sample numbers in this cluster implying Cluster 2 reflects basal stratigraphic sections [Fig. 3.2.2]. All samples in this group have scores on PC1 $>0$ and distribute on PC2.

\section{Faunal Cluster 3}

Cluster 3 has only a few indicator genera [green; Figs. 3.2.2-3.2.6]. It appears to be driven by a strong presence of Bryozoa with minor influences from genera such as Tawera or Stiracolpus [Fig. 3.2.6]. This could be because these samples perhaps lack genera which are common and found to be influential within the other groups such as Purpurocardia. Alternatively, lacking genera common to Cluster 1 such as Zygochlamys, Notosaria, and Ostrea may also be defining characteristics of this sample clustering [Fig. 3.2.5]. All samples in Cluster 3 have scores < 0 on PC1 and distribute on PC2 [Fig. 3.2.5]. 
CHAPTER THREE

\section{Faunal Cluster 4}

Figure 3.2.4 suggests that the presence of Stiracolpus and Tawera, with minor influence from Calloria, Bryozoa and barnacles strongly distinguishes the red Cluster 4 from the other three. This Cluster is distributed on PC1 and completely scores $>0$ on PC2 [Fig. 3.2.3].

\subsection{ANALYSIS OF TAPHONOMIC DATASET}

\subsubsection{Analysis process for collected data}

Of the original six taphonomic features recorded, two were not used in the analysis. Specimen orientation was always mixed and not in life position. While the degree of abrasion was found be nearly unchanging and consistently moderate throughout the shellbed. Hence, both orientation $(\mathrm{O})$ and abrasion $(\mathrm{A})$ records were not used in the analysis. Given that the description of the Hautawa Shellbed taphonomic features were based on the classification scheme for taphonomic facies from Hendy et al. (2006) their facies interpretation is also applied later to the depositional environment interpretations.

In raw, collected form, the taphonomic data is categorical and so the same data analysis as the faunal data cannot be applied directly. Normally, Multifactor Analysis (MFA) is used for considering the interactions between recorded attributes when they are of different data type: categorical vs numeric. Here, the taphonomic data frame was able to be converted into binary form using the function MFA. After this, the same approach was used to find clusters as with the assemblage dataset. The same transformation (making the sum of squares equal to one) was carried out on the taphonomic data for the same reasons as described above for the faunal data.

The same analysis (k-means clustering) approach used with the macrofaunal dataset was applied to the taphonomic data set. Figure 3.3.1 presents the results of partitioning produced using the cascadeKM function. The ssi criterion suggests that the best partitioning of the taphonomic dataset is with three clusters [Fig. 3.3.1]. A partition subdividing the data set into four clusters is nearly as highly valued (ssi $=0.093$ vs 0.096 ). 
Clearly, any partitioning with more than 3 clusters produces a scattered distribution and samples are not consistently placed in the same cluster. Inspection of Figure 3.3.1 shows the major difference between three or four clusters is that one cluster (green) is very stable in both partitioning options but two (red and yellow) are divided to form the fourth (purple). Therefore, a three-cluster partition of the dataset has been used to preserve the inherent stability of the first cluster (green). The driving taphonomic attributes of each of the three clusters are shown by the variable vectors in Figure 3.3.3. The colours of clusters shown in Figure 3.3.1 are completely independent of those used in Figures 3.2.2 and 3.2.3 and described below.

Figure 3.3.1: Plot produced by cascadeKM in order to exhibit how the local maximum ssi criterion is reached when three clusters are found within the taphonomic dataset.
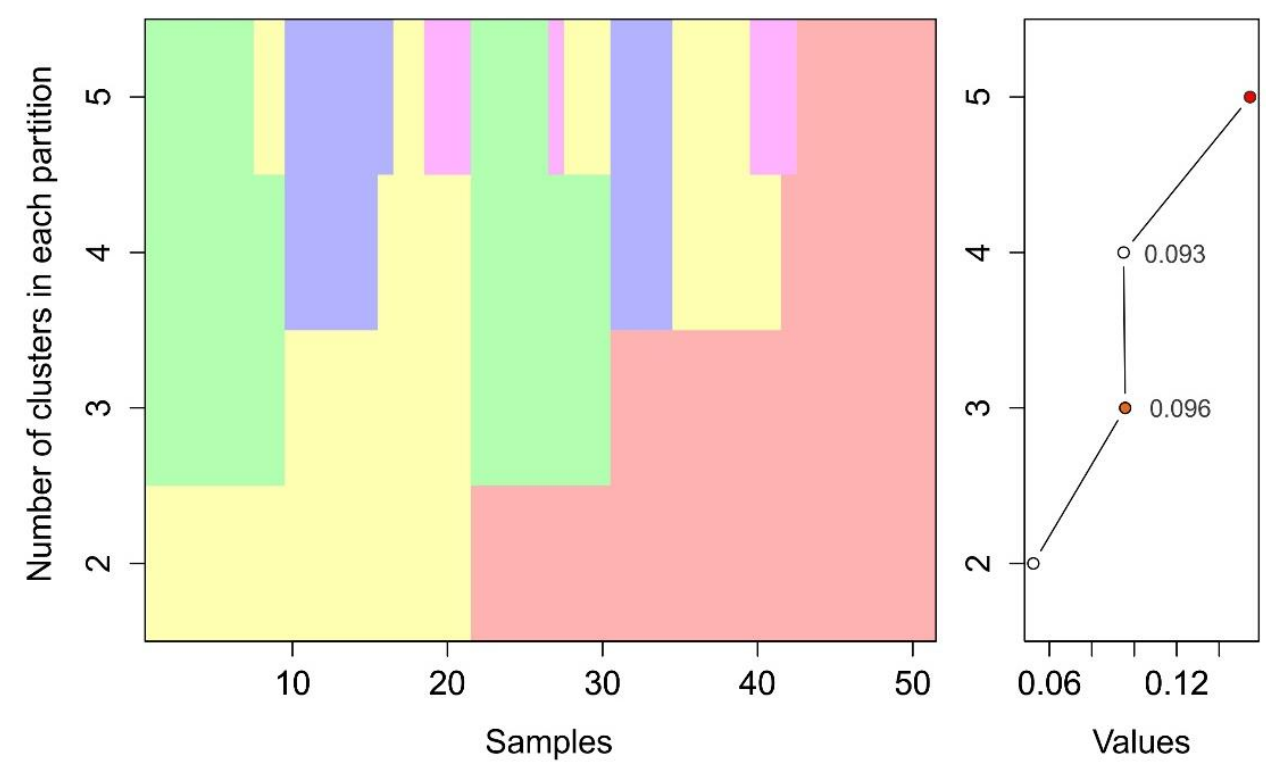

\subsubsection{Observed taphonomic clusters}

\section{Taphonomic Cluster 1}

The first cluster, shown in purple [Figs. 3.3.2-3.3.4], is represented by specimens which are: moderately poorly sorted, highly fragmented, and moderately packed. Hence, this cluster is most similar to Hendy et al.'s facies for wave or current winnowed bed or shell lag bed.

\section{Taphonomic Cluster 2}

The second cluster, shown in orange [Figs. 3.3.2-3.3.4], is driven primarily by specimens being: poorly sorted, with dominantly to mixed fragmentation, and densely 
packed. This most closes matches either the amalgamated or sediment starved shellbed facies of Hendy et al. (2006).

\section{Taphonomic Cluster 3}

The third cluster, shown in dark blue [Fig. 3.3.2 and 3.3.3], is moderate in most characteristics. Specimens are: moderately to poorly sorted, mixed or dominantly fragmented, and densely packed, and all disarticulate. So this group is more closely related to the winnowed bed of Hendy et al. (2006).

Interestingly, there appears to be no link between the faunal assemblage content recorded and the taphonomy described. This is shown in Figure 3.3.4 which displays the three taphonomic clusters applied to the principal component space of the faunal dataset. The overlapping nature of the three ellipses and clusters infers that there is no link between faunal and taphonomic partitioning of the macrofaunal dataset. If there was a link between taphonomy and faunal content, the taphonomic clusters would plot more distinctively as clusters in faunal PC space.

Figure 3.3.2: Plot of taphonomic clusters with 95\% ellipses in principal component space showing sample points.

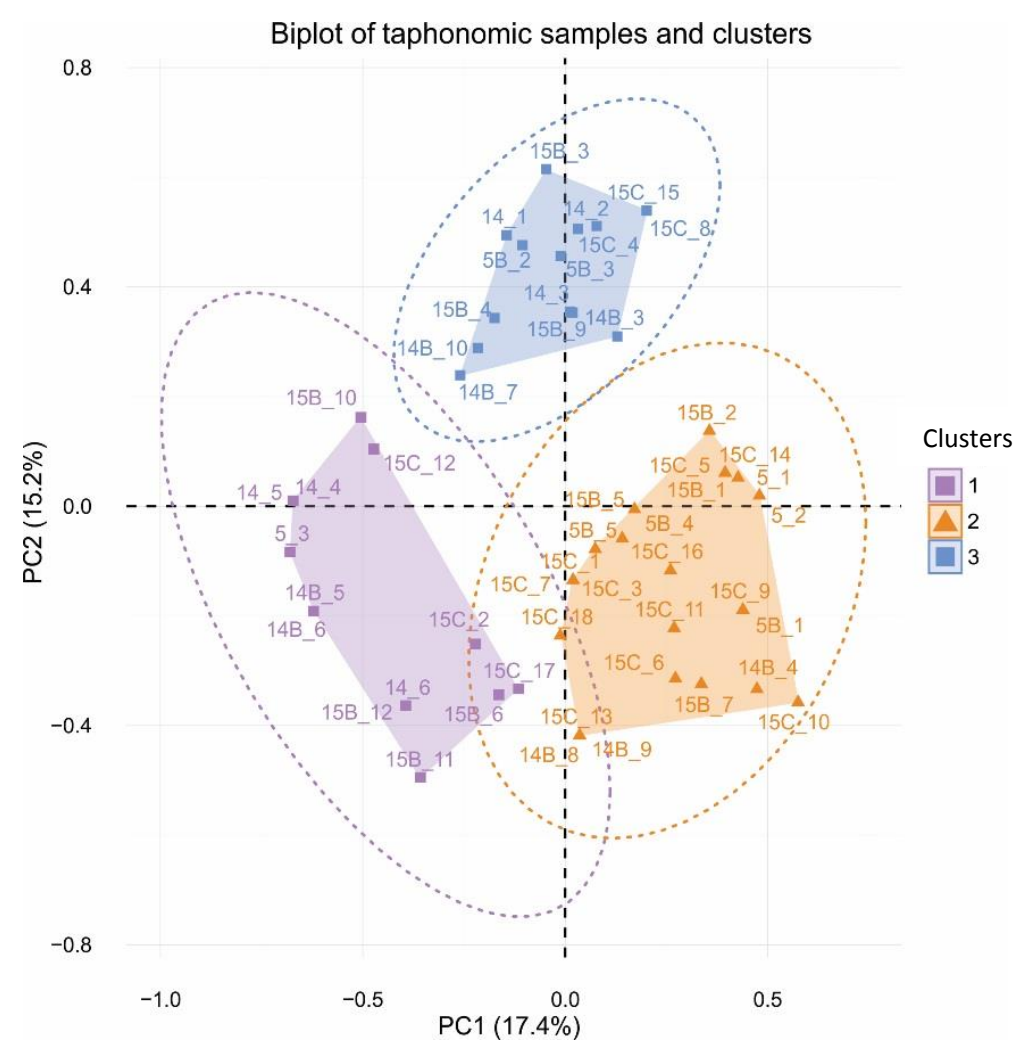


Figure 3.3.3: Bi-plot of taphonomic clusters in principal component space showing sample characteristics

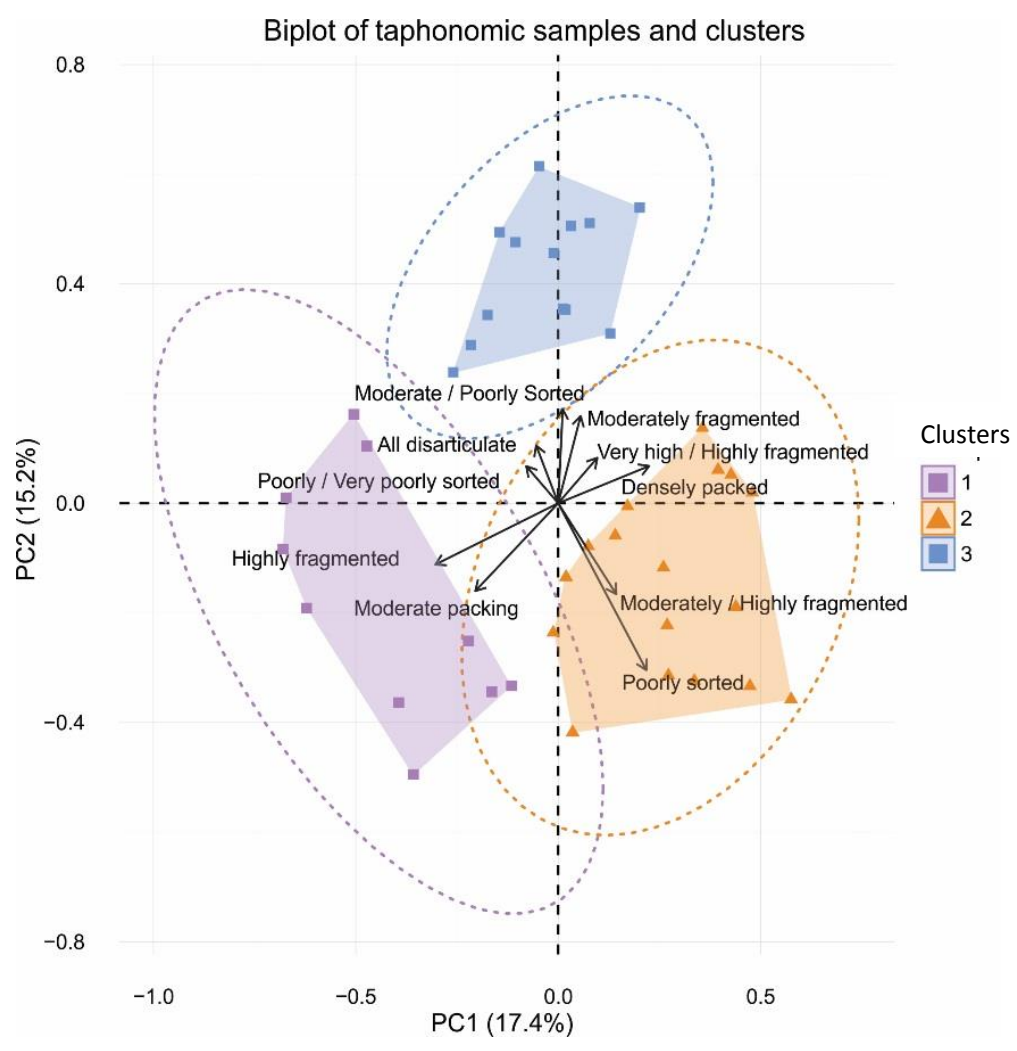

Figure 3.3.4: Bi-plot of taphonomic clusters plotted in faunal assemblage principal component space showing faunal vectors. This plot is produced by calculating and plotting the PCA of the faunal dataset but retaining plotted clusters formed by the taphonomic data analysis.

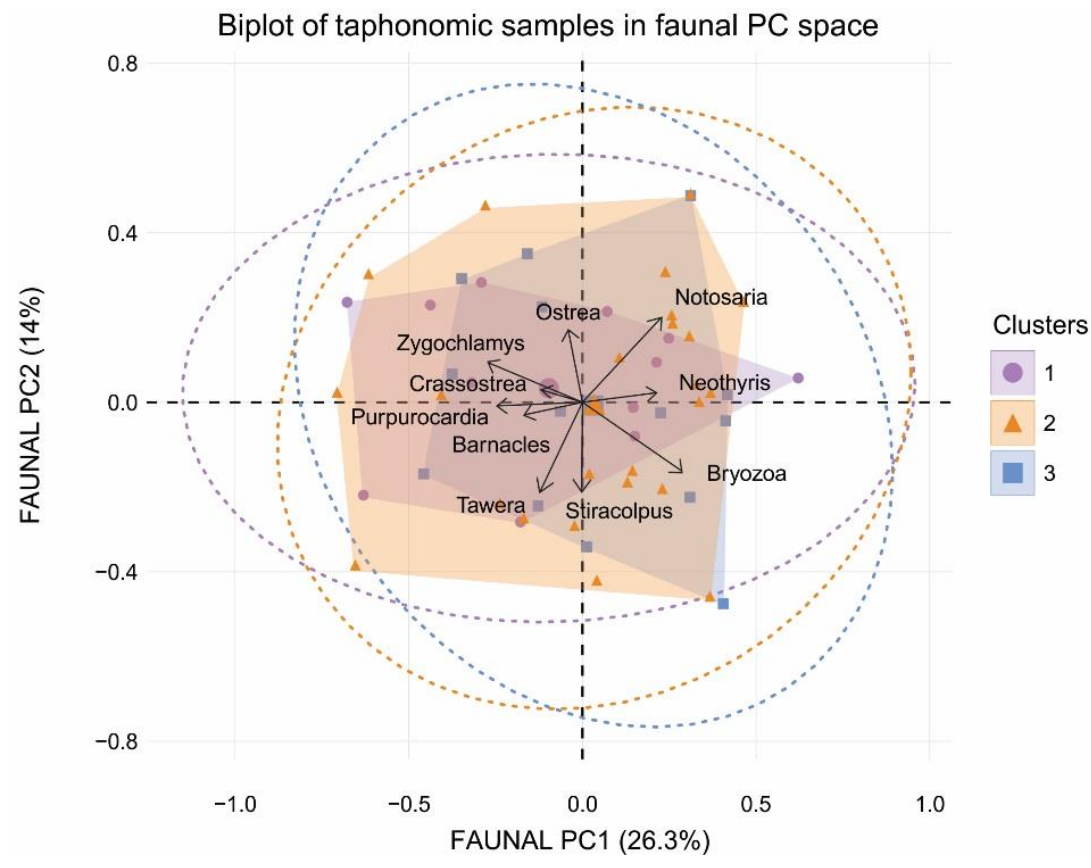




\subsection{BIOFACIES ANALYSIS}

\subsubsection{Constructing biofacies from clusters}

Figure 3.4.1 provides an illustration of the method used here. The clusters determined from both the faunal and taphonomic data are combined to produce what is termed a 'biofacies' [grey; Table 3.4.1]. These biofacies are the result of the persistent combinations of taphonomic and faunal clusters which are commonly observed together as the clusters of successive 'units' in the measured sections of the Hautawa Shellbed. In total, six different biofacies major variations are present, numbered 1 to 6 [grey; Table 3.4.1]. For example, biofacies " $1 \mathrm{a}$ " relates to a subunit which contains faunal cluster " 3 " and taphonomic cluster " 2 or 3 " as described above in section 3.3 [Table 3.4.1].

In Table 3.4.1, the clusters recorded with arrows, such as " $4 \rightarrow 1$ ", relate to biofacies where the lower units match cluster four and units further up-section match cluster one. Mixed numbers of clusters together are recorded as " 1 or 4". In contrast, if one cluster dominates a section but there are other rare clusters also seen they are recorded as "3 (1)". This would be a region dominated by cluster three with the odd cluster 1 sample also mixed in.

Figure 3.4.1: Illustration of biofacies and subunits displayed on measured section B at West Road. Full section included in the Enclosure.

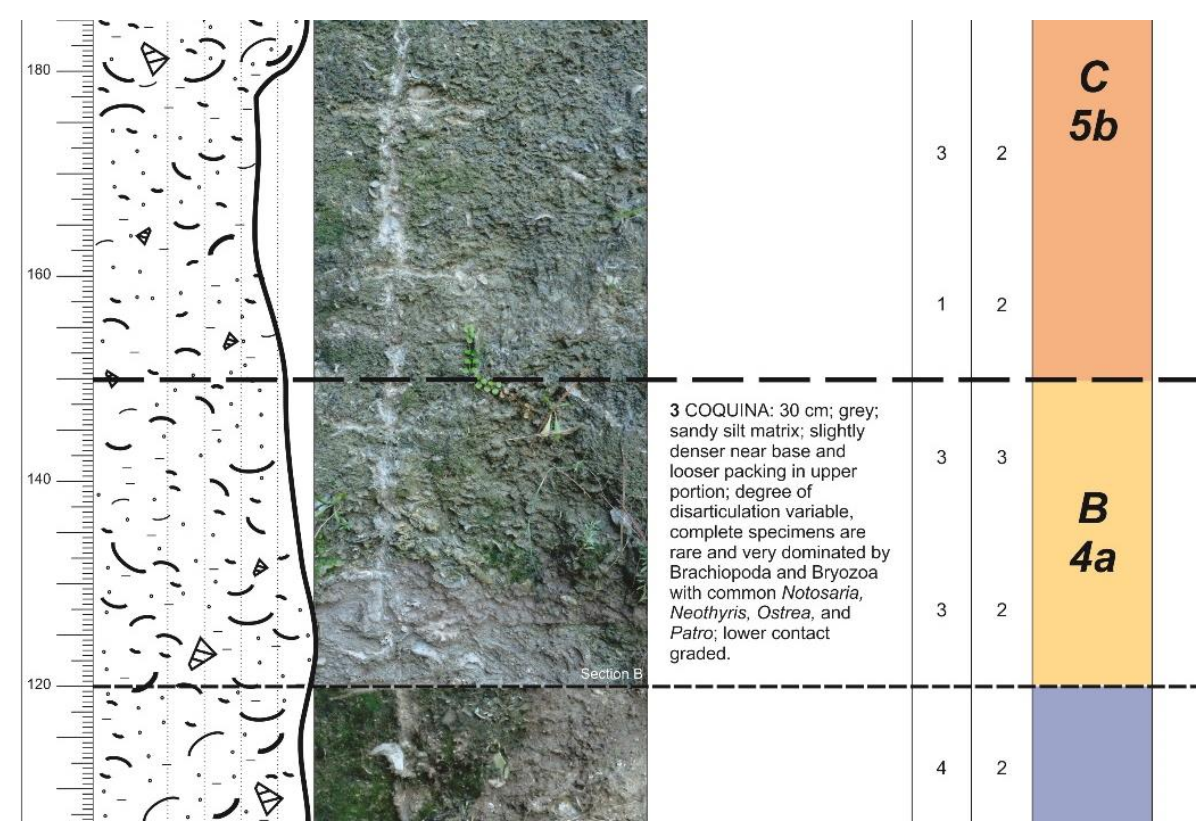


Table 3.4.1: Biofacies scheme for Hautawa Shellbed built on cluster analysis of faunal and taphonomic datasets.

\begin{tabular}{|c|c|c|c|c|}
\hline Biofacies & $\begin{array}{c}\text { Faunal } \\
\text { cluster(s) }\end{array}$ & $\begin{array}{c}\text { Taphonomic } \\
\text { cluster(s) }\end{array}$ & Description & Subunits \\
\hline $1 a$ & 2 & 2 or 3 & $\begin{array}{l}\text { Strongly driven by the presence of Zygochlamys, Purpuro- } \\
\text { cardia, and Crassostrea, along with the presence of barna- } \\
\text { cles. Mostly amalgamated and sediment starved bed ta- } \\
\text { phonomy with some winnowed bed features. }\end{array}$ & \multirow{5}{*}{ A } \\
\hline $1 b$ & 2 & $2 \rightarrow 1$ & $\begin{array}{l}\text { Strongly driven by the presence of Zygochlamys, Purpuro- } \\
\text { cardia, and Crassostrea, along with the presence of barna- } \\
\text { cles. Sediment starved and amalgamated bed taphonomy } \\
\text { and becoming dominated by winnowed or lag bed fea- } \\
\text { tures. }\end{array}$ & \\
\hline $2 a$ & $2 \rightarrow 4$ & 2 (1 or 3$)$ & $\begin{array}{l}\text { Lowest portion is driven by the presence of Zygochlamys, } \\
\text { Purpurocardia, and Crassostrea, along with the presence } \\
\text { of barnacles. Becomes influenced more by Stiracolpus, } \\
\text { Tawera and Crepidula with loss of Zygochlamys and } \\
\text { Crassostrea. Mostly an amalgamated bed taphonomy with } \\
\text { mixed lag or winnowed bed features. }\end{array}$ & \\
\hline $2 b$ & $2 \rightarrow 4$ & $3 \rightarrow 1$ & $\begin{array}{l}\text { Lowest portion is driven by the presence of Zygochlamys, } \\
\text { Purpurocardia, and Crassostrea, along with the presence } \\
\text { of barnacles. Becomes influenced more by Stiracolpus, } \\
\text { Tawera and Crepidula with loss of Zygochlamys and } \\
\text { Crassostrea. Sediment starved and winnowed bed tapho- } \\
\text { nomy with increasing lag bed features. }\end{array}$ & \\
\hline 3 & $4(2)$ & 3 or 2 or 1 & $\begin{array}{l}\text { Dominated by Stiracolpus, Tawera, Purpurocardia and } \\
\text { Crepidula, with minor influence from Ostrea, Sigapatella } \\
\text { and perhaps Bryozoa. Small influence of Zygochlamys and } \\
\text { Crassostrea and barnacles also. Mixed taphonomy of } \\
\text { amalgamated or sediment starved along with winnowed } \\
\text { bed features. }\end{array}$ & \\
\hline $4 a$ & 3 & $2(3)$ & $\begin{array}{l}\text { Mixed fauna, mostly hard-substrate dwelling. Barnacles, } \\
\text { bryozoa, and brachiopods (Notosaria, Neothyris and Callo- } \\
\text { ria) likely dominating. Mixed taphonomy of amalgamated } \\
\text { or sediment starved along with winnowed bed features. }\end{array}$ & \multirow{2}{*}{ B } \\
\hline $4 b$ & 3 & $2(1)$ & $\begin{array}{l}\text { Mixed fauna, mostly hard-substrate dwelling. Barnacles, } \\
\text { bryozoa, and brachiopods (Notosaria, Neothyris and Callo- } \\
\text { ria) likely dominating. Mixed taphonomy of winnowed or } \\
\text { lag beds. }\end{array}$ & \\
\hline $5 a$ & 1 or 3 & $1(3)$ & $\begin{array}{l}\text { Mixed fauna. Barnacles, bryozoa, Crepidula, Ostrea, Pur- } \\
\text { purocardia, Tawera, Notosaria and Calloria likely dominat- } \\
\text { ing with minor influences of Zygochlamys and barnacles. } \\
\text { Mixed taphonomy of mostly amalgamated or sediment } \\
\text { starved beds but with influence of winnowed or lag beds } \\
\text { also }\end{array}$ & \multirow{4}{*}{ C } \\
\hline $5 b$ & 1 or $3(4)$ & 2 (1 or 3 ) & $\begin{array}{l}\text { Mixed fauna. Barnacles, bryozoa, Crepidula, Ostrea, Pur- } \\
\text { purocardia, Tawera, Notosaria and Calloria likely dominat- } \\
\text { ing with minor influences of Zygochlamys and barnacles. } \\
\text { Taphonomy of winnowed or lag beds. }\end{array}$ & \\
\hline $6 a$ & 1 & 2 & $\begin{array}{l}\text { Crepidula, Ostrea, Notosaria, and Purpurocardia, with mi- } \\
\text { nor influence from Zygochlamys, Sigapatella, Neothyris } \\
\text { and possible presence of barnacles. Mixed taphonomy of } \\
\text { mostly amalgamated or sediment starved beds but with } \\
\text { influence of lag beds also. }\end{array}$ & \\
\hline $6 b$ & $1(2)$ & $2(3)$ & $\begin{array}{l}\text { Crepidula, Ostrea, Notosaria, and Purpurocardia, also with } \\
\text { some influence from Zygochlamys and the presence of } \\
\text { barnacles. Mixed taphonomy of mostly amalgamated or } \\
\text { sediment starved beds but with influence of lag beds also. }\end{array}$ & \\
\hline
\end{tabular}


The features of each biofacies found a within the Hautawa Shellbed have been described and related based on taphonomic descriptions to the shellbed types of Hendy et al. (2006) [Description; Table 3.4.1]. For example, linked to deposition of a sediment starved bed or a lag bed.

The biofacies are documented in the measured sections included as enclosures. Figure 3.4.1 illustrates how this is expressed for section B, West Road. The section is structured from left to right as: scale, graphic log, outcrop photograph, description, for each 'cell' a column of the faunal cluster, a column of taphonomic cluster. This is followed by the biofacies code which clusters group into (e.g. 4a). Finally, the subdivision is also include as described below (yellow, B).

\subsubsection{Using biofacies to subdivide the sections}

It was observed that biofacies 1, 2, and 3 are always in the lowest portion of the Hautawa Shellbed, while 5 and 6 were consistently overlying them in the upper portion at all sites. Biofacies 4 was also observed at the West Road site, occurring between these lower and upper portions. This pattern has been used to produce 'subunits' for the Hautawa Shellbed which can be correlated between sites across the Whanganui Basin [Table 3.4.1, Figs. 3.4.1 and 3.4.2]. Biofacies 1, 2, and 3 are grouped into subunit A; bio-facies 4 into subunit B; and biofacies 5 and 6 into subunit C [Table 3.4.1].

Therefore, as shown in Table 3.4.1, subunit $A$ is almost always made up of faunal clusters 2 and 4 alongside a range of all taphonomic clusters. In contrast, subunit B only contains faunal cluster 3 and dominantly taphonomic cluster 2 . Subunit C occurs mostly with faunal cluster 1 commonly with either taphonomic cluster 1 or 2 .

\subsubsection{Implications at sites of subunits}

Figure 3.4.2 demonstrates how the subunits observed in the Hautawa Shellbed based on changes in faunal assemblages and taphonomic characteristics can be traced between sites. 


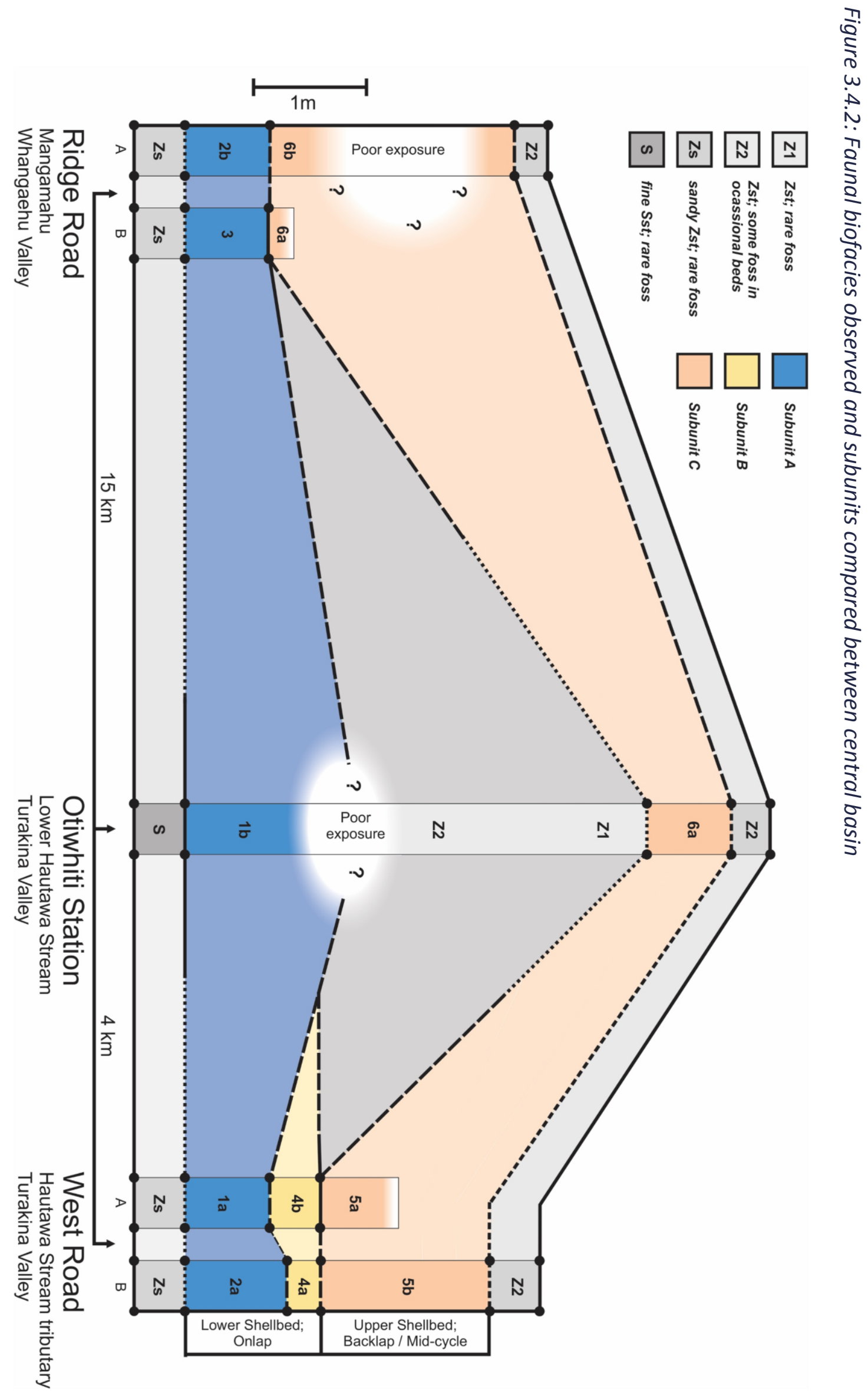




\section{CHAPTER THREE}

\section{Ridge Road, Mangamahu}

Two measured sections were made at this site, JEGE_14 [Enclosure 1, section A and section $B$ ]. Both sections contain the two major subunits ( $A$ and $C$ ), but express slight variation in their biofacies [Fig. 3.4.2].

The Hautawa Shellbed is described in this region by McIntyre (2002) as constructed of three segments, which is broadly consistent with what was observed in this study. Mclntyre (2002) observed the lowest 0.5 to $1 \mathrm{~m}$ contained mostly reworked fauna and that the central $0.8 \mathrm{~m}$ was dominated by calyptraeids (slipper limpets). Mclntyre (2002) also claimed that the upper $1.2 \mathrm{~m}$ was unique in containing the brachiopod $\mathrm{Ma}$ gasella along with Ostrea. While Magasella was not observed in this study, there is a change to dominant colonizing fauna (bryozoans and brachiopods) recorded in the Shellbed in the upper portion and this is consistent with subunit $\mathrm{C}$.

\section{Old Hautawa Road, lower Hautawa Stream; Otiwhiti Station}

The measured section as documented here is constructed from a number of smaller overlapping sections and covers a continuous $6.4 \mathrm{~m}$ of strata (JEGE_5). Two subunits ( $A$ and $C$ ) are expressed here and uniquely are divided by a poorly fossiliferous intra-shellbed siltstone [Fig. 3.4.2]. This is consistent with description of Hautawa Shellbed elsewhere (McIntyre \& Kamp, 1998). $1.5 \mathrm{~m}$ of barren siltstone was observed by Mclntyre and Kamp (1998) at Parikino, in the Whanganui River valley which is $20 \mathrm{~km}$ further westward of the Ridge Road site and a total of $34 \mathrm{~km}$ westward from the Old Hautawa Road site.

\section{West Road, upper Hautawa Stream; Otiwhiti Station}

Both measured sections from West Road contain all three subunits within the shellbed - A, B, and C [Fig. 3.4.2]. The second section (B), also constructed as a composite section, contained a total of $3.2 \mathrm{~m}$ of strata detailing all three subunits. $2.5 \mathrm{~m}$ was also measured nearby (section A), but the upper contact of the shellbed was overgrown, though the lower portion is very well exposed. 


\subsubsection{Environmental interpretation of subunits}

Subunit $A$

The lowest subunit $(A)$ is made up of faunal clusters which lack bryozoa and brachiopods. Subunit A is the most clearly traced between all central basin sites. This suggests that prior to the deposition of this lowermost bed, the paleo-sea floor at midshelfal water depth lacked a hard-substrate and was mostly soft bottomed. This idea is strengthened by the presence of fauna such as Purpurocardia and Tawera (Clusters 4 and 1) more commonly in lower samples, taxa that prefer a soft-bottomed habitat.

\section{Subunit B}

The central shellbed subunit (B) is located only at West Road sites and has a mixed fauna with preference for a hard substrate. The brachiopods and bryozoa, alongside limpets (Crepidula and Sigapatella) which dominate this subunit, all indicate the need of pre-existing shelly lag deposits formed by subunit $A$ to initiate formation of this deposit.

\section{Subunit $C$}

The overlying subunit $(C)$ is made up of fauna with a mixture of environmental preferences. Limpets and brachiopods are still the common and dominating fauna in subunit C. In contrast, bryozoans have become less significant than for in subunit B at West Road and not common at the other more western sites. Interestingly, the softbottom preferring Purpurocardia are present in this assemblage but Tawera and Stiracolpus become very rare. The more robust valves of Purpurocardia are possibly reworked into this unit better than the more delicate fauna and are hence present.

\subsubsection{Paleo-water depth of fauna}

The preferential habitat water depth ranges of key fauna observed in subunits are plotted in Figures 3.4.3-3.4.5. Water depth ranges are based on correlation to modern fauna and collated from previous studies (A. Beu \& Maxwell, 1990; A. G. Beu \& Raine, 2009; G. Cooper \& Lee, 1993; D. Lee, 1978; Mclntyre, 2002). 


\section{Subunit A}

This plot shows that the fauna are sourced from a water depth range of deeper than $5 \mathrm{~m}$ and shallower than $40 \mathrm{~m}$ [Fig. 3.4.3], therefore the fauna preserved are of an inner shelf origin in subunit A. Key constraining taxa are Purpurocardia and Sigapatella [Fig. 3.4.2 A], which have ranges of up to $40 \mathrm{~m}$ and greater than $5 \mathrm{~m}$, respectively.

\section{Subunit $B$}

Fauna observed in subunit B [Fig. 3.4.4] are sourced from water depths deeper than $20 \mathrm{~m}$ but shallower than $40 \mathrm{~m}$. The dominant fauna are Mesopeplum and Sigapatella [Fig. 3.4.4], which have ranges of up to $40 \mathrm{~m}$ and greater than $20 \mathrm{~m}$; respectively.

This suggests a deepening of faunal assemblage source since deposition of subunit $A$. This is consistent with the incorporation of more dominant brachiopods and bryozoans here. The data also suggest the assemblage comes from an inner shelfal environment, though with both narrower range and toward the deepest inner shelf.

\section{Subunit C}

This subunit has the same lower boundary for faunal water depth as subunit B but has a slightly larger range of $20 \mathrm{~m}$ to $45 \mathrm{~m}$. The fauna preserved in subunit C also imply a source faunal assemblage water depth of the deepest inner shelf. The influential fauna are Mesopeplum and Crepidula [Fig. 3.4.2 C], which have ranges of up to $40 \mathrm{~m}$ and greater than $20 \mathrm{~m}$; respectively.

While all three subunits contain dominant fauna which are suggested to be sourced from an inner shelfal (less the $50 \mathrm{~m}$ water depth) environment, many taxa (such as Notosaria, and Stiracolpus) which are common throughout are often found in much deeper environments also. Today, Zygochlamys is restricted to the outermost shelfal and continental slope water depths of up to $600 \mathrm{~m}$ (Orpin et al., 1998). This living water depth is very contrasting to the environments preferred by the other dominant fauna. Hence, here Zygochlamys is inferred to have been transported prior to deposition into the shallower water depth of the inner shelf. 
Figure 3.4.3: Water depth range chart for macrofauna in Subunit $A=$ range of 5 to $40 \mathrm{~m}$.

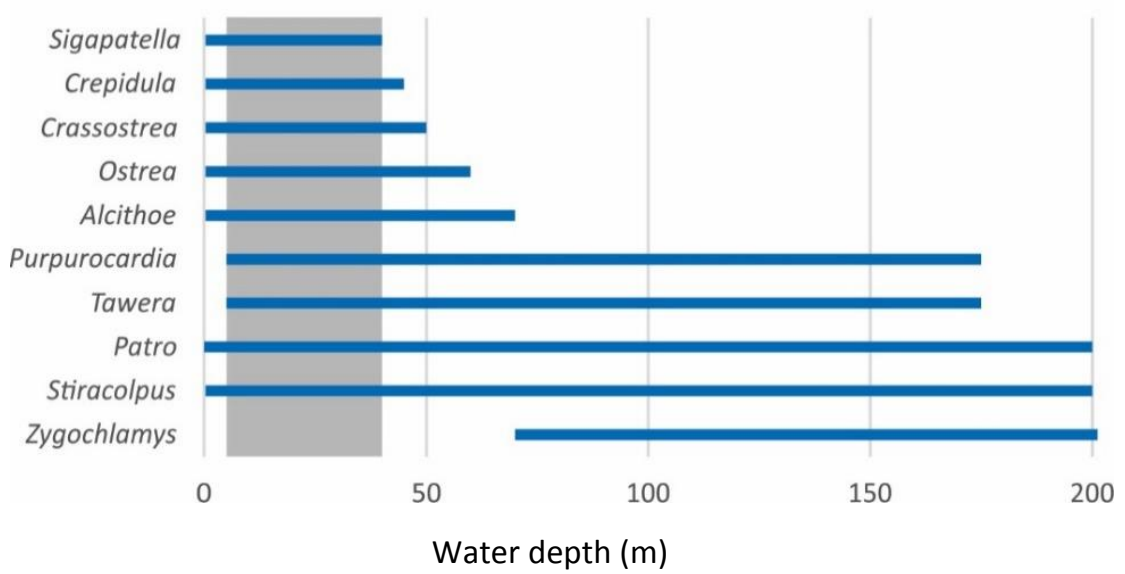

Figure 3.4.4: Water depth range chart for macrofauna in Subunit $B=$ range of 20 to $40 \mathrm{~m}$.

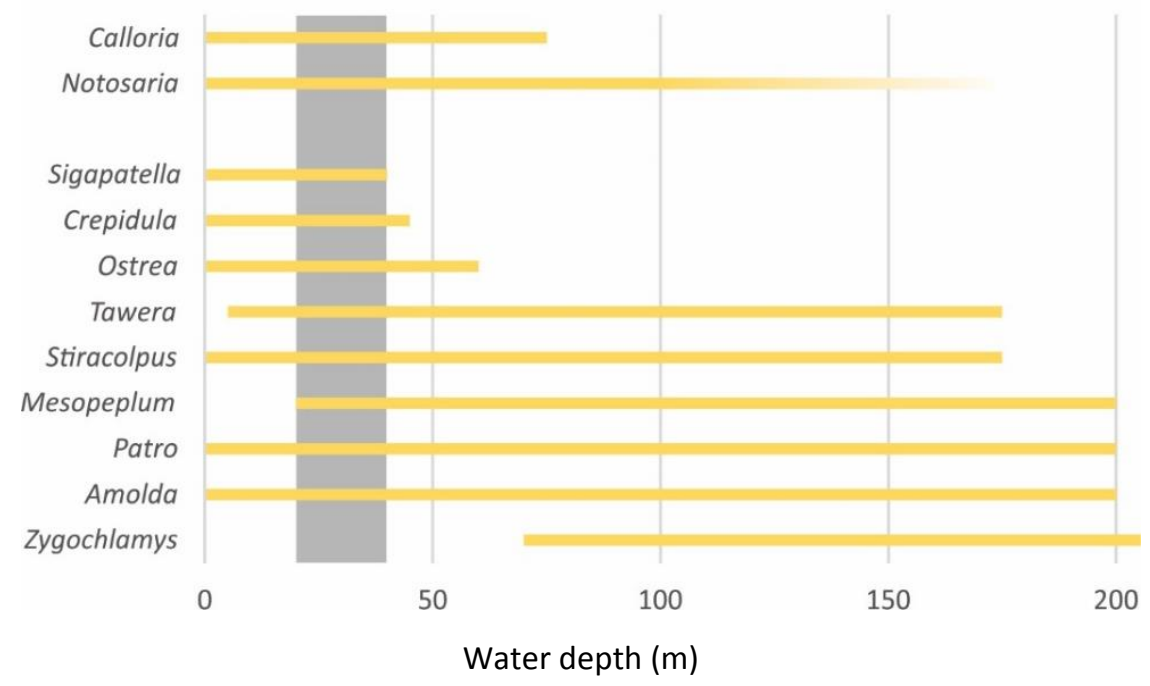

Figure 3.4.5: Water depth range chart for macrofauna in Subunit $C=$ range of 20 to $45 \mathrm{~m}$.

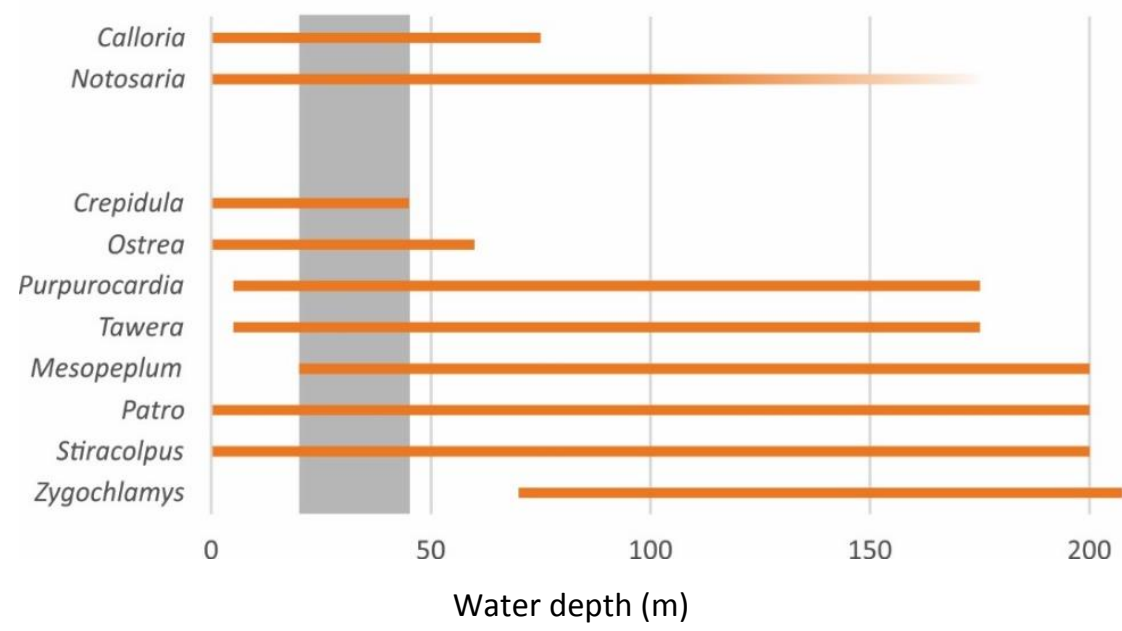


This combination of fauna with contrasting environmental preferences was noted by Fleming (1953). He comments that while the complete assemblage has no modern analogue the "combination of Chlamys and Brachiopoda forms a distinctive association in southern New Zealand... Probably several associations are present in the Hautawa Shellbed... comparable communities on the present sea-bottom have a depth range of from 6 to 25 fathoms" (pg. 132) (Fleming, 1953). This equates to a paleo-water depth range inferred by Fleming based on the complete fauna of from $\sim 11 \mathrm{~m}$ to $\sim 46 \mathrm{~m}$. Therefore, the water depths suggested here for each subunit based on macrofaunal environmental preferences remain consistent with this early estimate for the paleoenvironment of the Hautawa Shellbed.

\subsubsection{Reworking and implications}

In their investigation of modern shellbeds, Orpin et al. (1998) describe condensed compound shellbed sections as containing two parts: a lower shellbed and an upper or 'mid-cycle' shellbed. They explain that the lower bed is a horizon dominated by transported molluscs that are a mixture of shoreface and inner-mid shelf-derived taxa. Hence, this lower unit records a higher degree of taphonomic damage due to further transport from sediment source to deposition. While the upper shellbed is packed with in situ fauna (such as brachiopods and bryozoans) it also contains a mildly transported assemblage which is dominated by shell-ground molluscs such as Zygochlamys, Ostrea, and Tawera. This is consistent with the makeup of modern shellbeds observed forming off the Otago coast (Orpin et al., 1998). Therefore, the upper shellbed has a lower signal of taphonomic reworking.

This is consistent with the findings and features of the subunits presented here. At all sites, subunit $A$ is overlain by subunit $C$ and this generally two-part expression is observed. Subunit A contains fauna from a shallower paleo-water depth than subunit $C$ [Fig. 3.4.2 A vs C]. Also, Subunit A is dominated by the taphonomic characteristics of winnowed or lag beds after Hendy et al. (2006) [Fig. 3.4.1]. These findings are consistent 
with the a lower shellbed dominantly forming as a transgressive lag deposit (Kondo et al., 1998; Orpin et al., 1998).

Subunit $\mathrm{C}$ contains an assemblage from a slightly deeper paleo-water depth [Fig. 3.4.2 C] and expresses a mixed taphonomic signal. This subunit has features which correspond to amalgamated beds and sediment starved deposition but also minor influence of winnowed and lag beds (Hendy et al., 2006) [Fig. 3.4.1]. The change in faunal assemblage to one dominated by colonizing organisms such as bryozoans and brachiopods is also consistent with the modern day observations of Orpin et al. (1998).

\subsubsection{Age range of macrofauna}

As discussed previously, the faunal assemblage of molluscs observed in the Hautawa Shellbed places the timing of deposition at the very earliest Nukumaruan Stage in the Whanganui Basin (R. Cooper \& Agterberg, 2004; Raine et al., 2015). As no previously unidentified species were found within the Hautawa Shellbed; there is no new evidence to suggest that this age is incorrect. Figure 3.4.6 emphasises the depositional age of the Hautawa Shellbed, based on a range chart of macrofauna present, is from the earliest Nukumaruan. Information for Figure 3.4.6 is sourced from A. Beu and Maxwell (1990), A. G. Beu (1995), and A. G. Beu and Raine (2009).

The three critical fauna which confirm this age are: Phialopecten triphooki which is limited to the earliest part of the Nukumaruan (A. G. Beu, 1995), Zygochlamys delicatula which is limited to only MIS 95-93 in the Whanganui Basin and Crassostrea ingens which occurs for the last time stratigraphically in the base of Hautawa Shellbed but is otherwise restricted to a last occurrence in the Mangapanian Stage. Hence, the Hautawa Shellbed marks the base of the Nukumaruan Stage in Whanganui Basin and is cyclo-stratigraphically tuned to $2.40 \mathrm{Ma}$ (Hollis et al., 2010). 


\section{CHAPTER THREE}

Figure 3.4.6: Age range chart of key molluscs observed in the Hautawa Shellbed compared to both the New Zealand Geologic Timescale and species age ranges in millions of years.

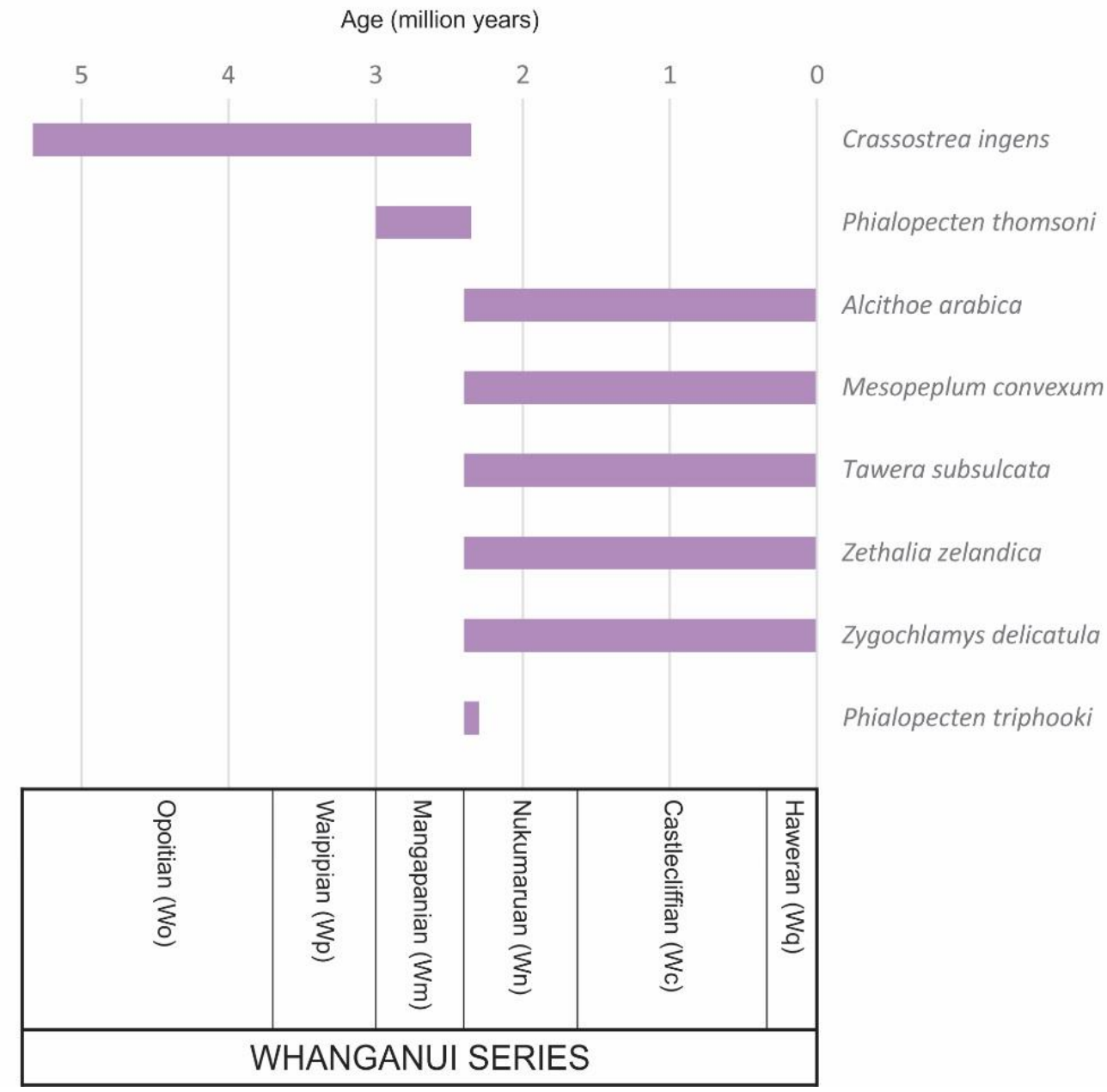




\section{CHAPTER FOUR \\ FORAMINIFERAL METHODOLOGY}

\subsection{INTRODUCTION}

Figure 4.2.1 outlines the structure of this chapter and Chapter 5. Chapter 4 focuses on the sediment sample processing methodology and the data collection used for microfauna. Chapter 5 will continue from this and explain the analysis carried out on the microfaunal dataset.

Considering the findings of Mildenhall (1978), Hornibrook (1981), and Jenkins (1971) discussed earlier, it is apparent that in investigating previous sediment samples for microfossils, pollen has been less significant than foraminifera in providing useful stratigraphic constraints for application to the Hautawa Shellbed. Based on this, sediment samples were chosen to be processed only for grain size distribution and foraminifera content.

\subsection{SAMPLE PROCESSING}

\subsubsection{Grain size}

Proxy for water depth

This approach is based on the methodology of Dunbar and Barrett (2005), using the percent mud in a sample as a proxy for water depth [Fig. 4.2.2]. The method relies on the strength of the landward-coarsening pattern in grain size observed on a wavegraded shelf. Driven primarily by wave induced shear stress on the sea bed, the wave climate critically alters the variance of this relationship (Dunbar \& Barrett, 2005). The authors showed that this approach was appropriate for Pliocene age strata from Whanganui. It has been successfully applied in recent investigations of similar aged New Zealand strata to quantitatively calculate the paleo-water depth of samples (BertaudGandar, 2015; Sefton, 2015).

The $\%$ mud weight for each sample was attained by collecting the water used during sediment washing and sieving at $63-\mu m$ for foraminifera. After settling for a few days, the excess clear water was siphoned off and the remainder oven dried (at $40^{\circ} \mathrm{C}$ ) 
Figure 4.2.1: Structure of Chapter 4 and Chapter 5.

Chapter 4

Chapter 5

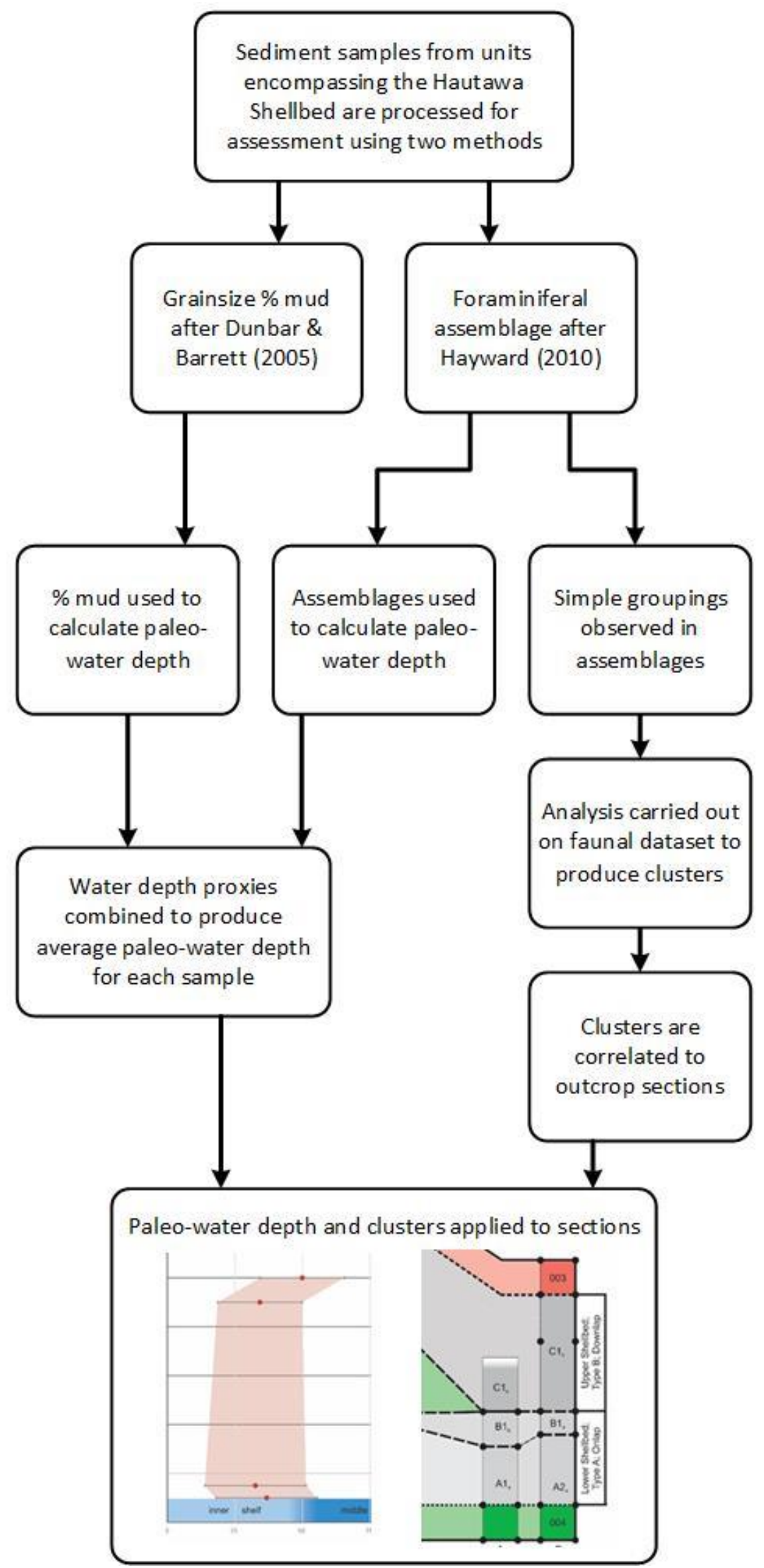

82 
before the less than $63-\mu \mathrm{m}$ fraction of sediment was weighed.

Figure 4.2.2: Plot of relationship between $\%$ mud and depositional water depth on a wave graded shelf, Figure 10 from Dunbar \& Barrett (2005). Based on data collected off the modern Manawatu coast and is fitted with a $4^{\text {th }}$ order polynomial.

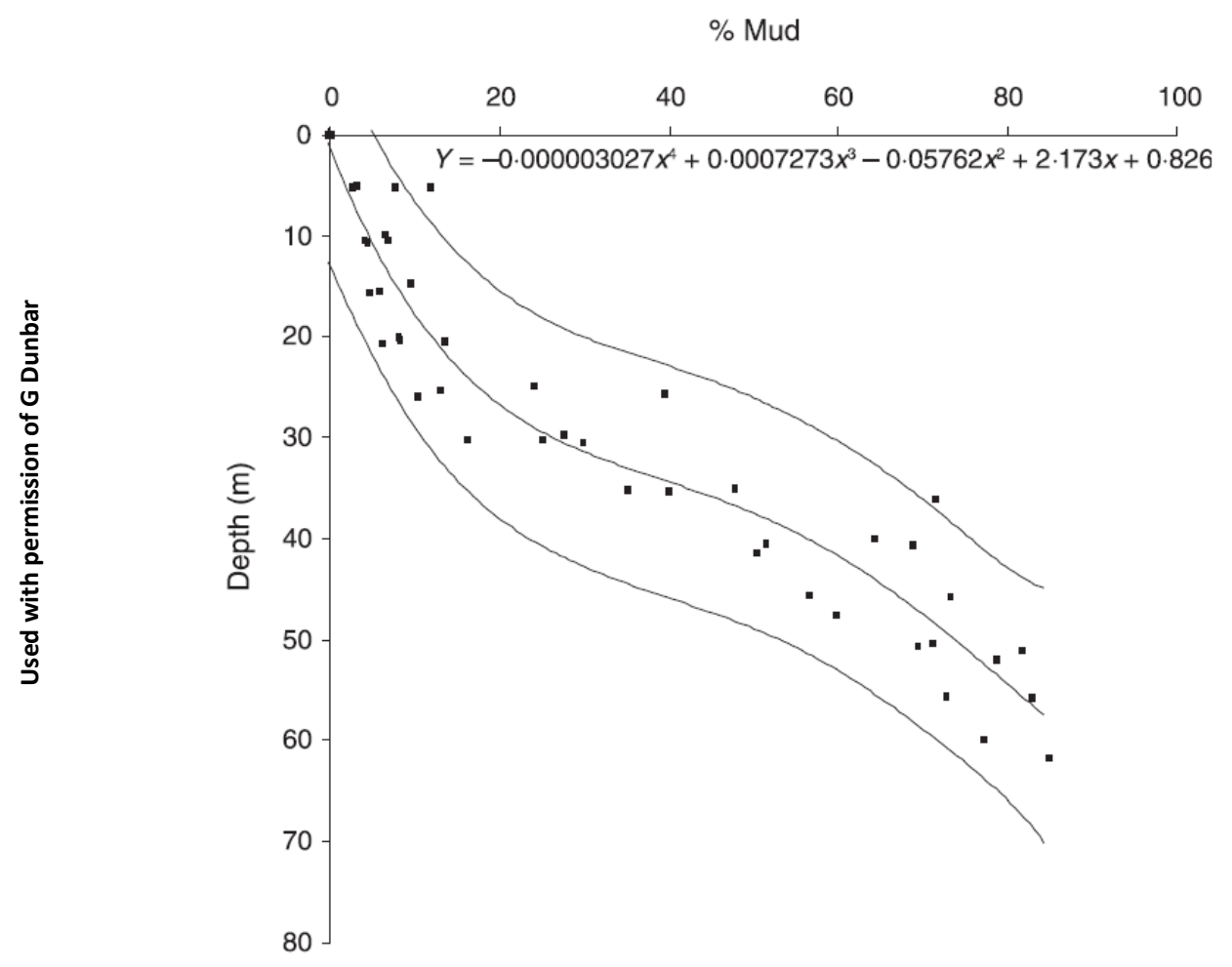

\subsubsection{Foraminifera picking}

The process shown in Figure 4.2.2 was followed to extract foraminifera from samples taken at each field locality. This produced an output of five dry fractions from a $50 \mathrm{~g}$ wet sub-sample. As all samples yielded only low numbers of planktic foraminifera, the approach set out in Hayward (2010), pg. 122, was followed with a few alterations.

Rather than the recommend 100 benthic specimens suggested in the rapid method, a minimum of 300 foraminifera were picked during step 2 from samples whenever possible. Hayward (2010) recommends picking from sample fractions coarser than $63 \mu \mathrm{m}$ (the sand-sized fraction). Primarily, two fractions were picked from in this study: $125 \rightarrow 150 \mu \mathrm{m}$ and $150 \rightarrow 500 \mu \mathrm{m}$. The finer fraction $63 \rightarrow 125 \mu \mathrm{m}$ was found to be generally barren of foraminifera or contained dominantly juvenile specimens only. Picked specimens were arranged by genera and, if possible species, on gridded assemblage slides. The faunal assemblages for each sample are included in the Appendix. 
Figure 4.2.3: Flow diagram of sample processing to produce foraminifera picking appropriate dry fractions - primarily from 63-500 $\mu \mathrm{m}$.
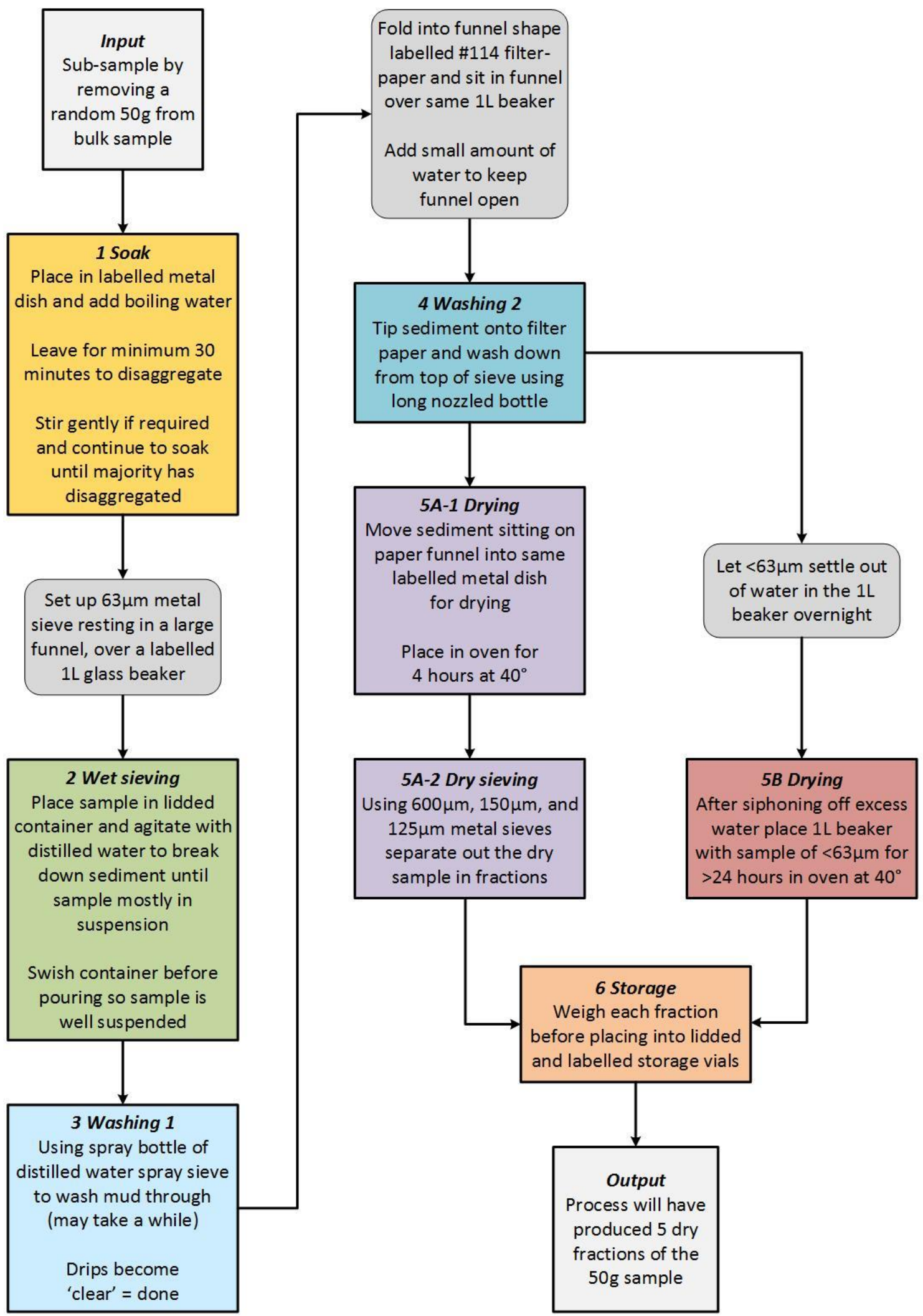


\section{CHAPTER FIVE \\ ANALYSIS OF FORAMINIFERAL DATA}

\subsection{INTRODUCTION}

Foraminifera are uniquely suited to producing quantitative estimates of paleoenvironment, particularly water depth. Samples were processed as outlined in Chapter 4.

Due to the post rapid environmental change occurring in environments of less than 100m, Hayward (2010) argues that their approach to paleo-depth assessment is accurate to within $10-20 \mathrm{~m}$ for inner to mid-shelf environments. Hayward defines segments of the marine shelf as shown in Figure 5.1.1. They consider the marine 'shelf' environment to be of the range of $0 \rightarrow 200 \mathrm{~m}$ water depth. With three sub-regions: inner $(0 \rightarrow 50 \mathrm{~m})$, middle $(50 \rightarrow 100 \mathrm{~m})$, and outer $(100 \rightarrow 200 \mathrm{~m})$.

The majority of samples were taken from fine sediments either lying immediately below (samples 002, 004, 007, 008 and 015) and above (samples 003, 005, 006, 009 and Figure 5.1.1: Summary of paleodepth and oceanicity based on New Zealand Neogene foraminiferal faunal assemblages (modified after Figure 89; Hayward, 2010).

Expected ranges for planktic percentage observed is given below each sub-region title.

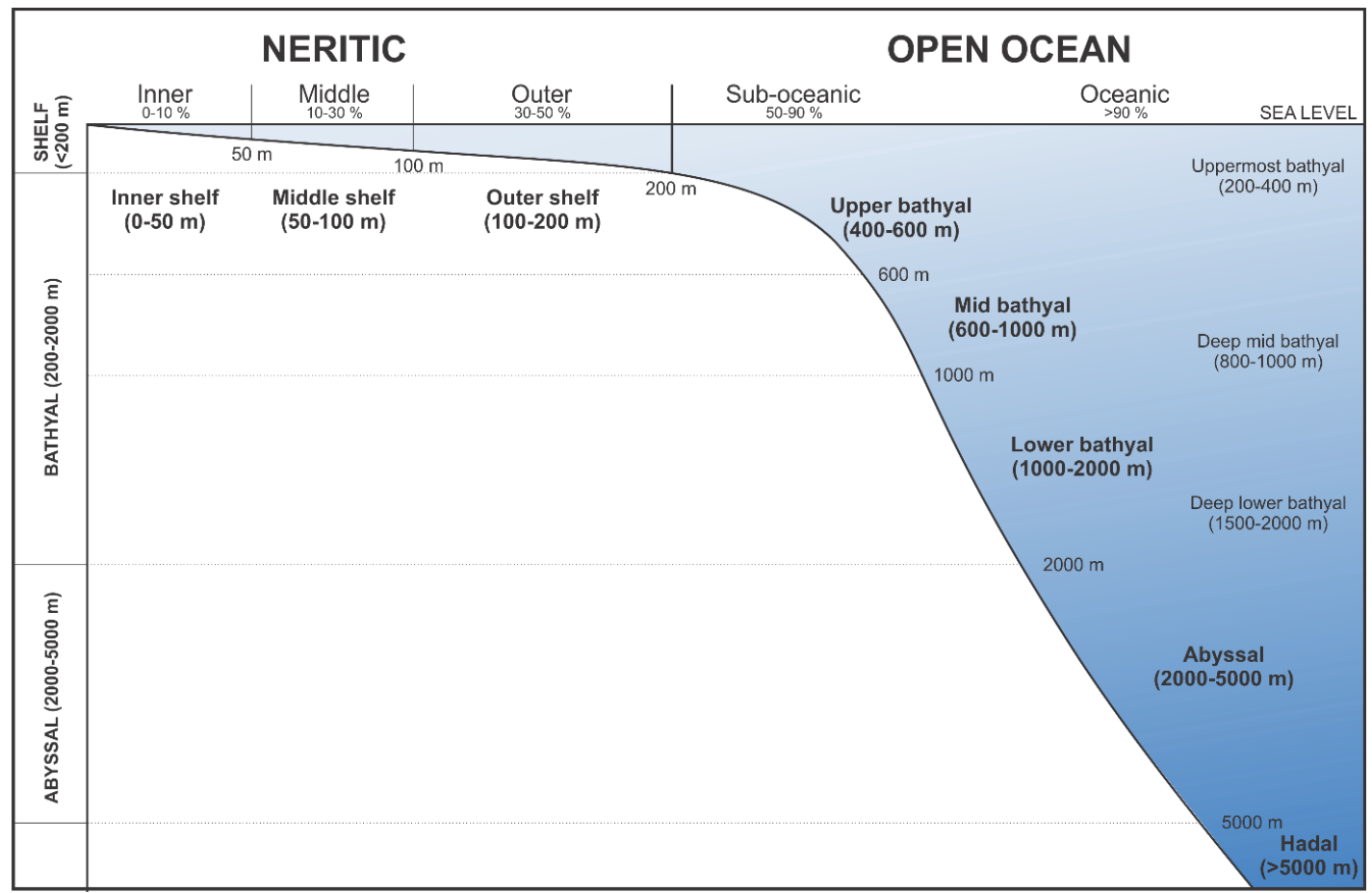




\section{CHAPTER FIVE}

014) the Hautawa Shellbed at each site in the central Whanganui Basin. This includes at West Road, at Otiwhiti Station, or at Ridge Road. Sample 001 from within the intra-shellbed silt at Old Hautawa Road, Otiwhiti Station. The exact position samples were taken at, relative to the Hautawa Shellbed, is shown by Figure 5.2.4.

Three samples were also assessed from siltstone units encompassing the limestone unit at Colenso Station at the eastern margin of the Whanganui Basin. Two from below (samples 010 and 012) and two from above (samples 011 and 013).

\subsection{ANALYSIS OF FORAMINIFERA}

\subsubsection{Faunal assemblages \\ First observations of content}

As described in section 4.2.2 (pg. 69), the approach of Hayward (2010) was followed for consideration of the foraminifera contained in samples. Foraminifera picking was carried out with the aim to pick 300 specimens from each sample. During picking, it was noted that some samples had quite distinctive and contrasting assemblages. In particular, samples from near the Hautawa Shellbed contained much lower numbers of planktic specimens than those from collected at Colenso Station.

The percentage observed key fauna identified form the sediment samples collected near the Hautawa Shellbed are compared between samples in Table 5.2.1. Only samples which are considered 'good quality' (>300 specimens picked) are shown here and used for further analysis, the following patterns are observed:

- Notorotalia are observed in high numbers ( $\gg 20 \%$ ) in all sediment samples collected from below the Hautawa Shellbed.

- There does not appear to be a connection between the presence Quinqueloculina and the sampled position.

- Relatively few $(\ll 10 \%)$ Nonionellina are recorded from all samples collected from above the shell bed, but a few were also picked in sample 001.

- Texulariidae are common ( $\gg 0 \%$ ) in all sediment samples collected above the shell bed. 
- Generally, the percentage of planktic foraminifera is higher $(\leq 3 \%)$ in samples collected from above the shellbed

There are some inconsistencies between the percentages and grouping the samples. For example, 006 has nearly no Quinqueloculina but it is a key common genus in other samples collected from above the Hautawa Shellbed.

Table 5.2.1: Percentages of common key foraminifera identified in samples. Bold text emphasising relative higher percentage values. Samples are grouped based on trends in observed during picking.

\begin{tabular}{|c|c|c|c|c|c|c|c|}
\hline Sample position & 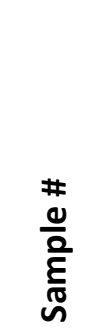 & 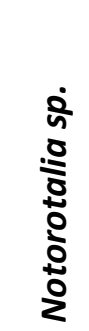 & 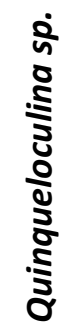 & 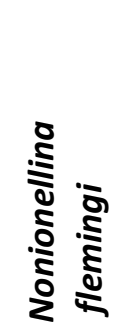 & 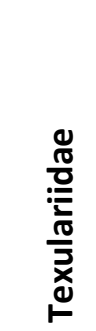 & $\begin{array}{l}\frac{y}{+\frac{U}{4}} \\
\frac{y}{c} \\
\frac{\pi}{a}\end{array}$ & SITE \\
\hline \multirow{3}{*}{ Above shellbed } & 015 & $46 \%$ & $0 \%$ & $12 \%$ & $0 \%$ & $0 \%$ & Ridge Road \\
\hline & 006 & $20 \%$ & $0 \%$ & $1 \%$ & $6 \%$ & $8 \%$ & Otiwhiti \\
\hline & 003 & $22 \%$ & $9 \%$ & $1 \%$ & $12 \%$ & $3 \%$ & West Road \\
\hline Intra-shellbed & 001 & $42 \%$ & $2 \%$ & $1 \%$ & $0 \%$ & $2 \%$ & Otiwhiti \\
\hline \multirow{3}{*}{ Below shellbed } & 014 & $23 \%$ & $4 \%$ & $0 \%$ & $8 \%$ & $6 \%$ & Ridge Road \\
\hline & 002 & $60 \%$ & $3 \%$ & $10 \%$ & $0 \%$ & $0 \%$ & Otiwhiti \\
\hline & 004 & $51 \%$ & $0 \%$ & $16 \%$ & $8 \%$ & $1 \%$ & West Road \\
\hline
\end{tabular}

Analysis methodology

In order to further examine the variability between sample assemblages, Principal Component Analysis (PCA) and cluster analysis using the k-means partitioning after a chord transformation were also carried out on the foraminiferal dataset. This is following the same methods from Borcard et al. (2011) as with the data collected in situ for macrofauna within the Hautawa Shellbed (section 3.2, pg. 46).

The peak the ssi criterion again clearly demonstrates that the best partitioning of the sediment samples based on their contained foraminiferal assemblage is with three clusters [Fig. 5.2.1].

\section{Correlating between samples}

This Principal Component Analysis (PCA) reveals strong links between samples. The bi-plot is produced through PCA of the foraminiferal dataset and shows both sample positions in PC space and also the fauna driving the distribution as vectors [Fig. 5.2.2]. 
Figure 5.2.1: Plot produced by cascadeKM in order to exhibit how the maximum ssi criterion is reached when three clusters are found within the foraminifera dataset.
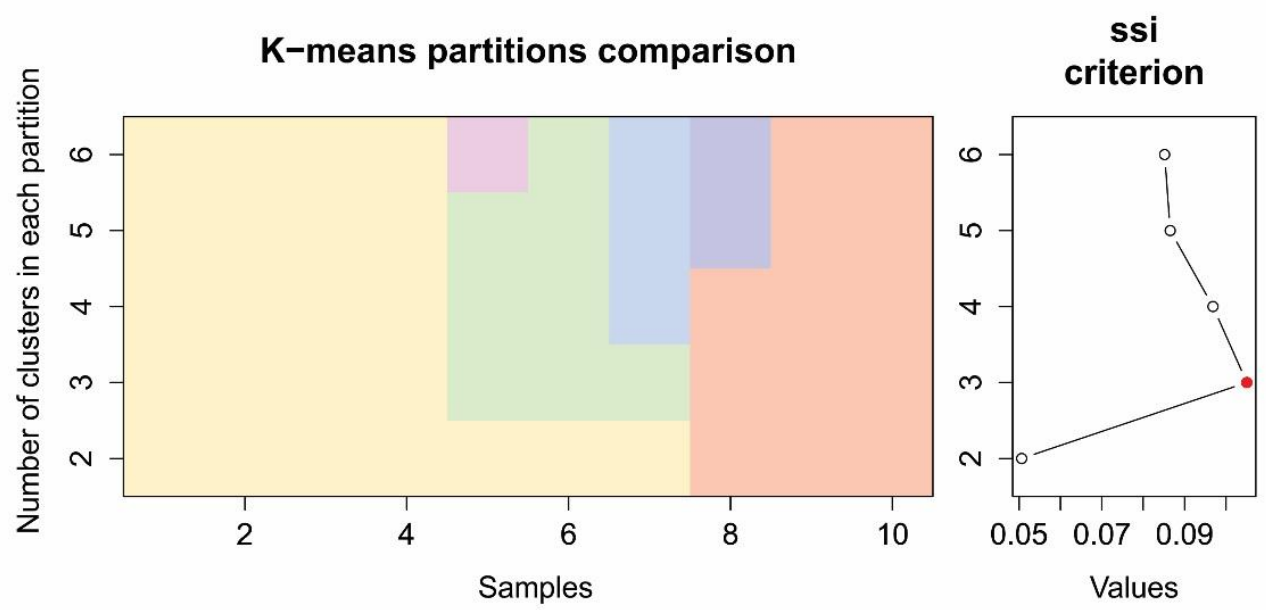

Only samples with ca. 300 specimens picked were included in this analysis as described earlier. The clusters identified by k-means partitioning are also shown [Fig. 5.2.2].

Interestingly, this partitioning and PCA places all sediment samples collected from below the Hautawa Shellbed in Cluster 2 [green; Fig. 5.2.2 and 5.2.4] and samples collected from above in Cluster 3 [red; Fig. 5.2 .2 and 5.2.4]. Also, sample 001 taken from the intra-shellbed silt is included in Cluster 2. Cluster 1 [blue; Fig. 5.2.2] containing all samples collected at Colenso Station is plotted distinctively apart.

\section{Foraminiferal Cluster 1}

Cluster 1 , containing samples 010,012 , and 013 [blue; Fig. 5.2.2], is quite distinctly plotted away from all other samples. This is not surprising as these sediment samples are unique from the others as they were collected from the silty units bracketing the unnamed limestone unit at Colenso Station. The strongest influence on these assemblages are from planktics such as Globigerina, and benthic Textulariidae along with Cassidulina and Cibicides. Though sample 010 contains similar Notorotalia amounts to some samples the green and blue clusters - around $20 \%$ of the sample. The increased amount of planktic specimens alone (all $>15 \%$ ) suggests samples in this cluster originate from a much deeper environment than the other samples. The ca. $20 \%$ planktic equates to at least middle shelfal water depths [Figure 5.1.1] (Hayward, 2010). 
Figure 5.2.2: Biplot produced for samples distributed based on foraminiferal assemblages.

Three distinct clusters are observed. Clusters identified using k-means with convex hulls drawn to highlight cluster regions in PC space. Large symbols are mean of clusters and the position of each sample is shown by small symbols with labels.

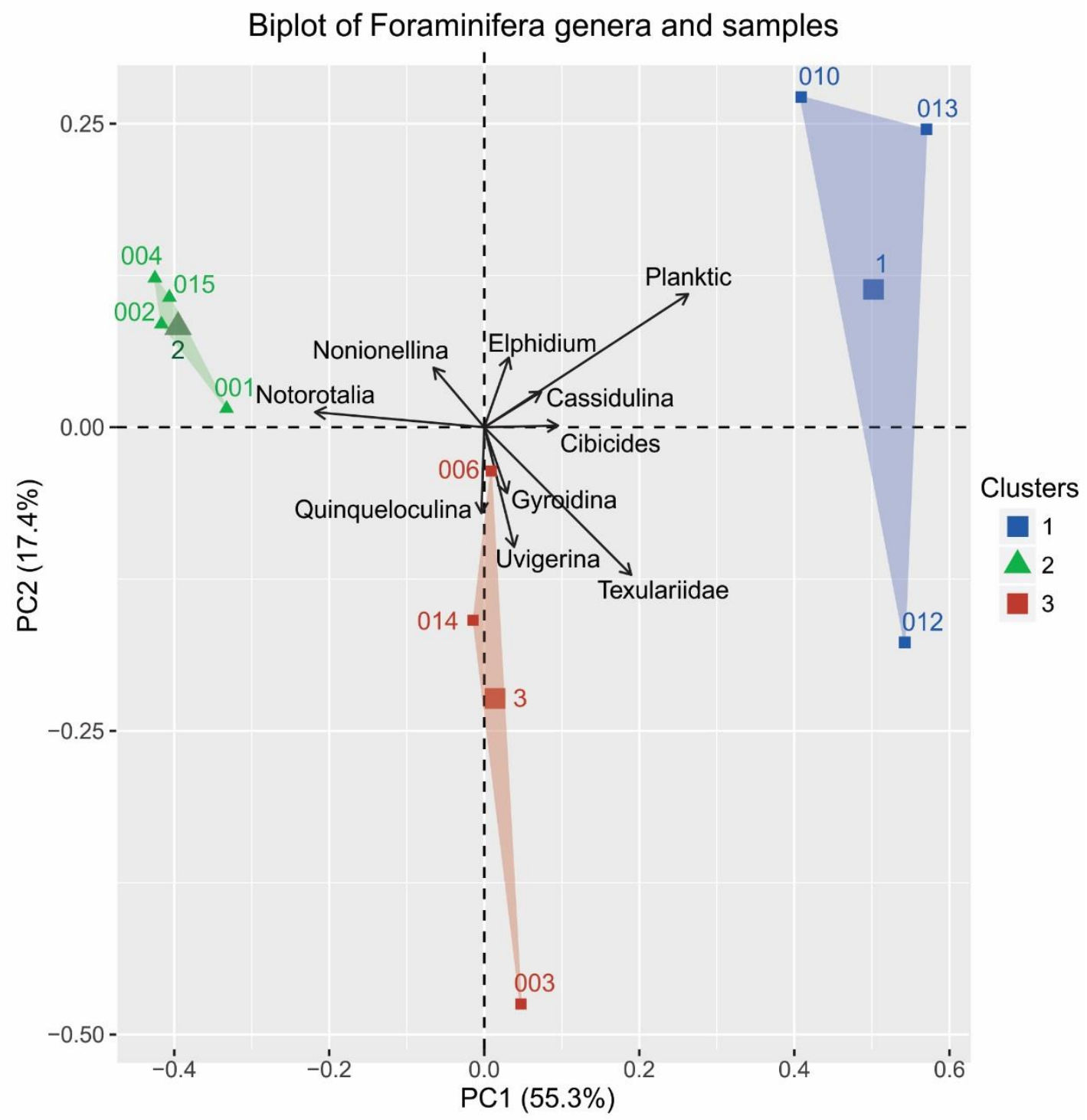

Foraminiferal Cluster 2

Cluster 2 [green; Fig. 5.2.2 and 5.2.4], is most strongly influenced by the presence of Notorotalia. All samples except 001 were collected from beneath the Hautawa Shellbed. Species of Notorotalia are considered to be an important indicator taxon for moderately sheltered bays and inlets with water depths of $2 \rightarrow 30 \mathrm{~m}$ (Hayward, 2010). 
Sample 001 comes from the siltstone between the lower and upper shellbed units at Old Hautawa Road. As well as foraminifera, this sample also yielded a significant number of juvenile brachiopods [Figure 5.2.3]. Brachiopods also prefer clear and calm water, which is consistent with the strong presence of Notorotalia (Hayward, 1999).

Figure 5.2.3: Juvenile brachiopods from sample 001, intra-shellbed siltstone on Old Hautawa Road, Otiwhiti Station. Viewed with light microscope.

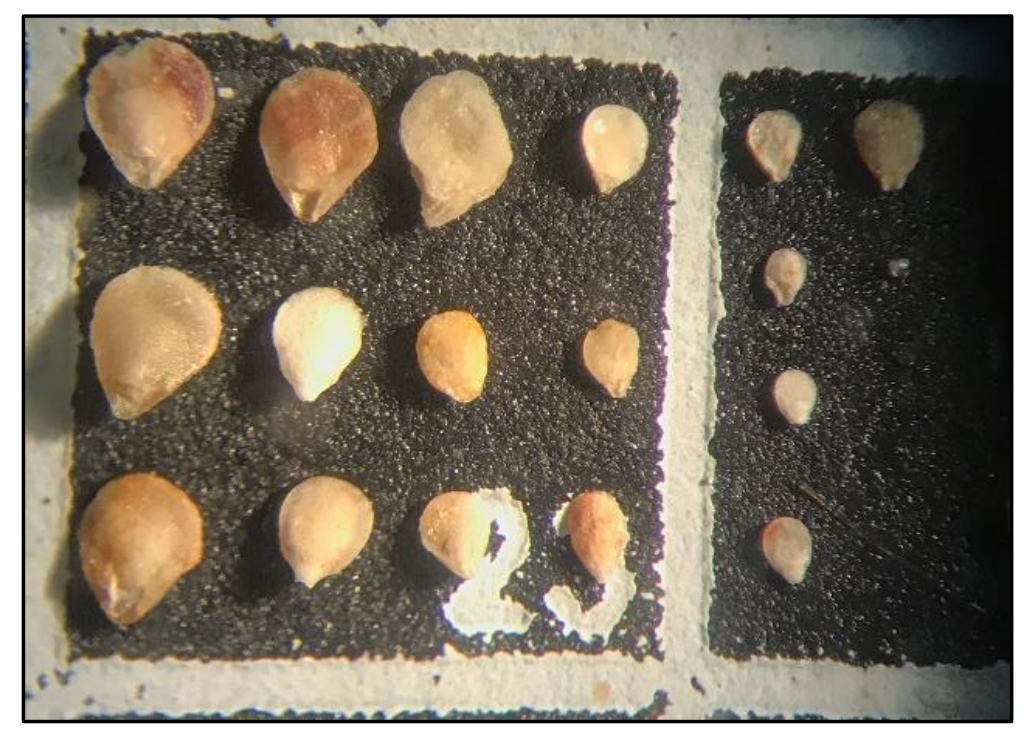

Foraminiferal Cluster 3

Samples in the Cluster 3 [red; Fig. 5.2.2 and 5.2.4] all come from the silt directly overlying the Hautawa Shellbed. Though these samples are dissimilar enough to be widely spaced in the plot, all appear to be strongly influenced by the presence of Uvigerina and Quinqueloculina, with lower numbers of Notorotalia (only ca. 20\%).

Increased numbers of Buliminoidea - but still lower than 30\% - such as Uvigerina, suggest that samples in Cluster 3 are from less than $100 \mathrm{~m}$, so deeper middle shelf at most. Quinqueloculina tends to be a dominant species in environments of less than $50 \mathrm{~m}$. But sample 003 contains one of the highest percentages of the globigerid form Gyroidina (9\%) - which is restricted to greater than 50m (Hayward, 2010) - so the contrast between 003 and 006 may be a deeper depositional water depth for sample 003. Hence, it is likely that samples in the red cluster are from the middle to possibly shallowest outer shelf environment based on their benthic assemblage. 


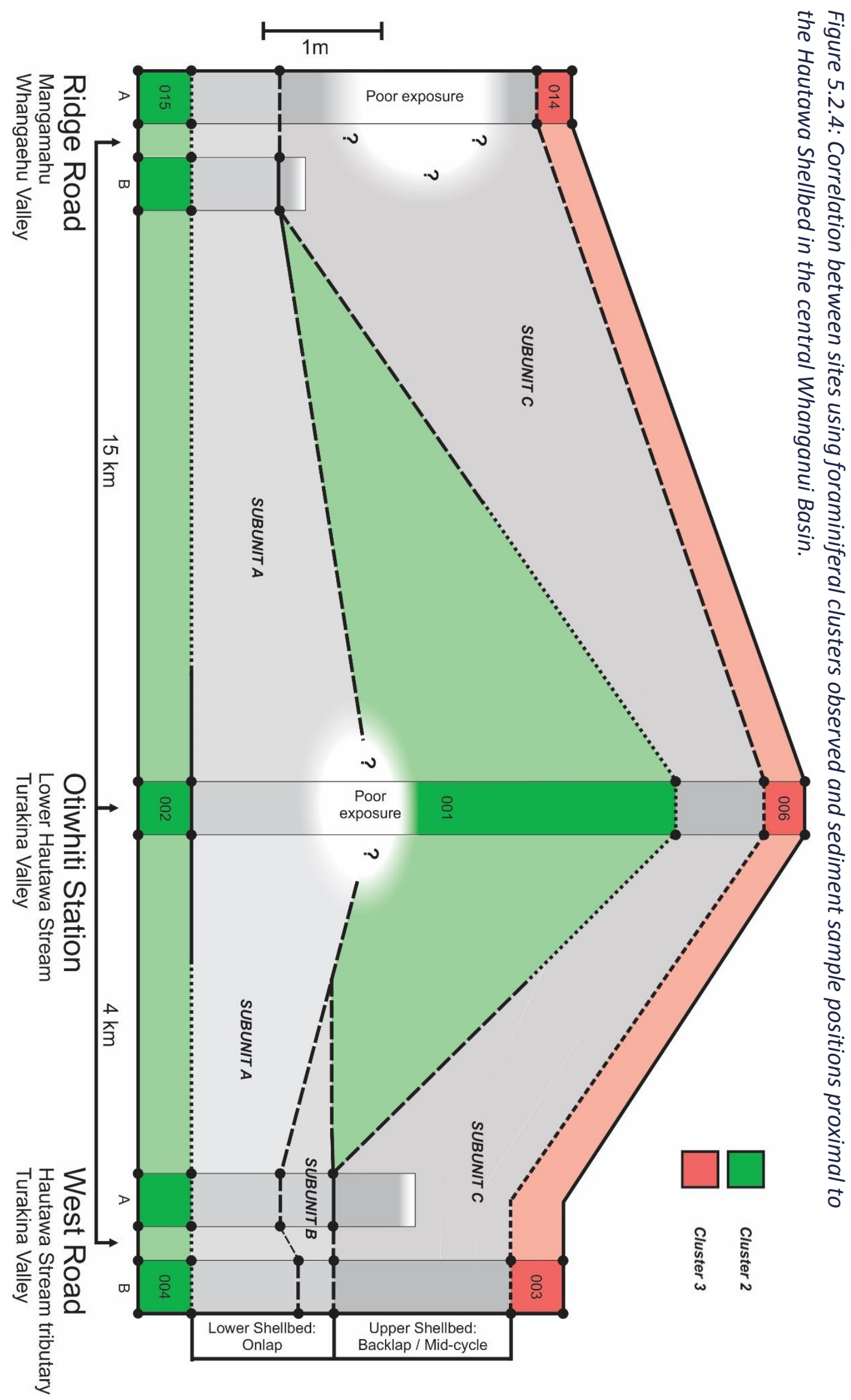




\subsubsection{Proxies and methods for paleo-water depth}

Planktic percentage

The percentage of planktic foraminifera present in a sample can be used as a simple proxy for water depth. Hayward (2010) gives the relationship with a $R^{2}$ value of 0.8283 for the trend of:

$$
\text { Water depth }(m)=27.35 \exp \left(0.042 \times \%_{\text {planktic }}\right)
$$

For example, In the case of sample 001 , with a $4.6 \%$ planktic content, this equates to a paleo-water depth of $33 \mathrm{~m}$.

\section{Assemblage proxies}

Benthic faunal assemblage percentages were compared to figures produced in Hayward (2010) to constrain depositional water depths. Figure 84 on pg. 111 of Hayward (2010) compares the percentages in an assemblage of given taxonomic orders with the expected water depth it corresponds to. The coloured regions correspond to $95 \%$ of their study faunas (reproduced in Figure 5.2.6).

Table 5.2.2: Results for water depth from various sources and proxies for sample 001.

Collected on West Road, Otiwhiti Station, from the intra-shellbed siltstone.

\begin{tabular}{l|c|c} 
Method & Depth $(\mathbf{m})$ & Uncertainty $(\mathbf{m})$ \\
\hline \% mud & 45 & 10 \\
\% planktic & 33 & 20 \\
Taxonomic order \%'s & 38 & 23 \\
Taxonomic genera \%'s & 40 & 10 \\
Average & 39 & 17
\end{tabular}

For sample 001 [Table. 5.2.2] the water depth range from the foraminiferal assemblage at order level is $38 \pm 23 m$ (2s. f.). Figure 5.2.6 shows how a paleo-water depth for a sample can be calculated based on the faunal percentages. The known percentage of each order from a sample is plotted on the diagram as a circle where it most appropriately fits within the known distribution for that order. The five circles give a clear range for the possible depositional water depths of the sample based on the percentages of taxonomic order contained. These match very well with the water depths calculated from the percentage of planktic foraminifera and also the percentage mud contained in each sample (Dunbar \& Barrett, 2005; Hayward, 2010) [Table 5.2.3]. 

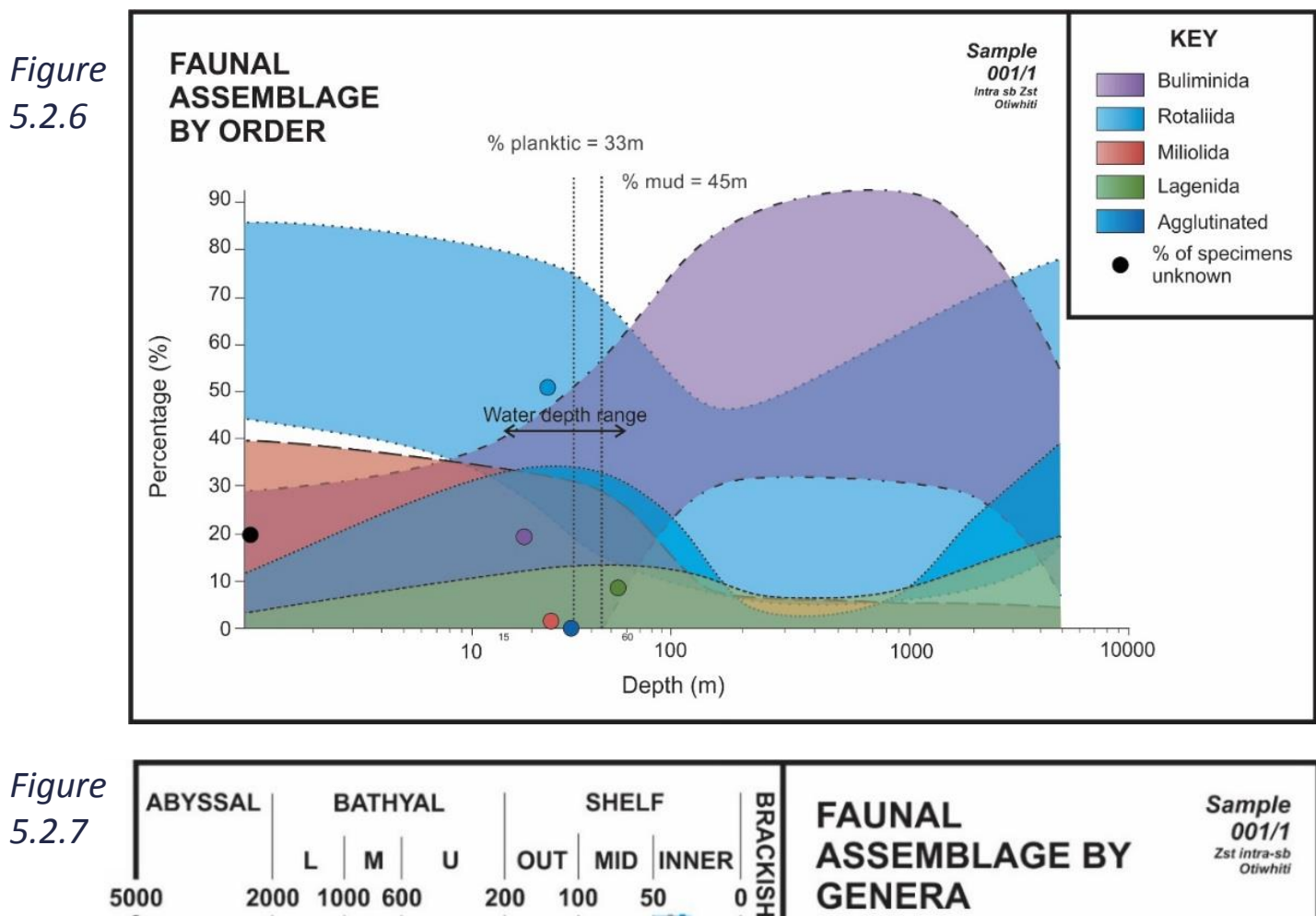
$\begin{array}{lllllll}5000 & 2000 & 1000600 & 200 & 100 & 50 & 0\end{array}$ GENERA

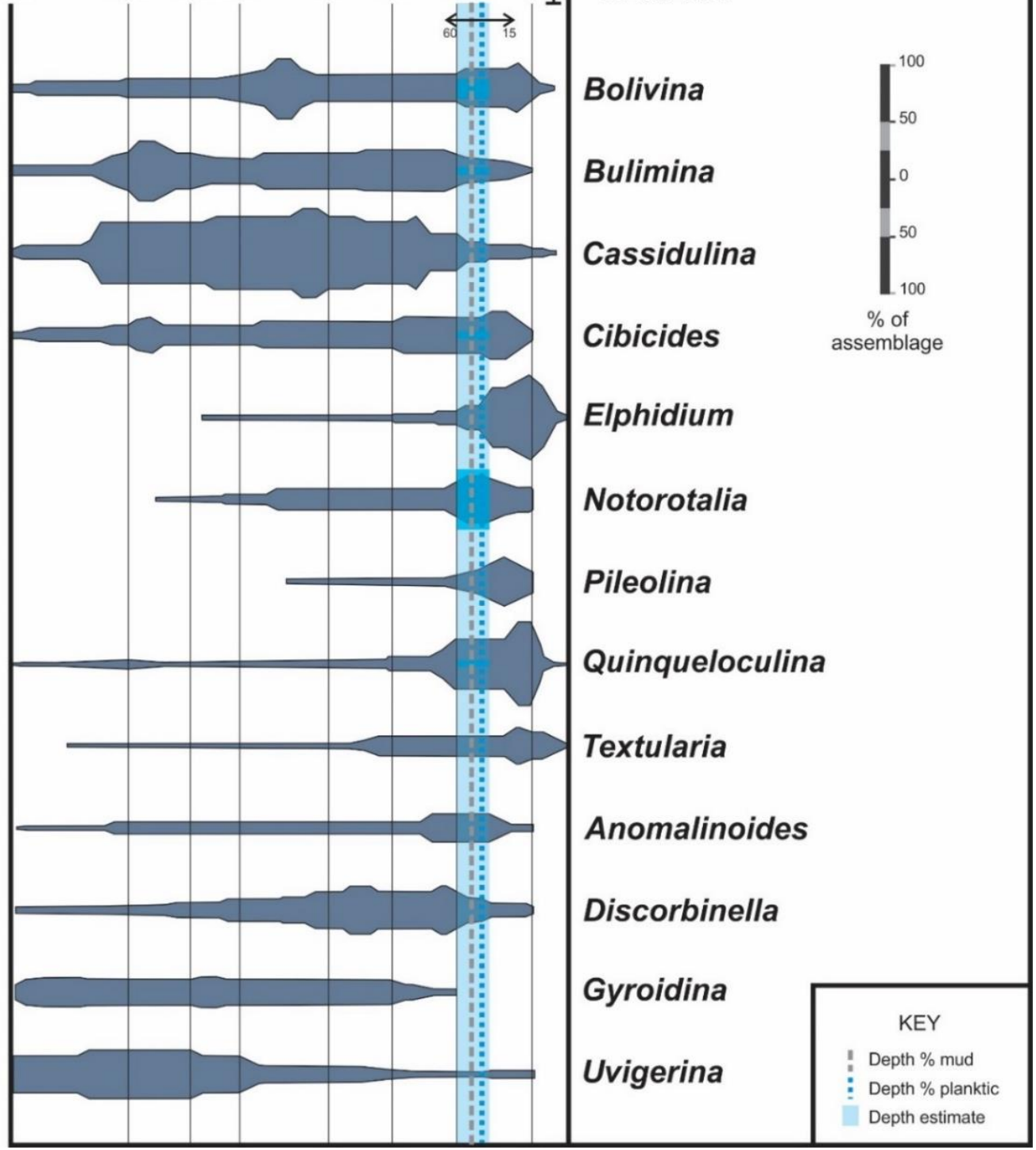


For sample 001 from West Road, the findings from each method are summarised as shown in Table 5.2.2. The overall average value for water depth from 001 is $39 \pm$ $17 \mathrm{~m}$, placing the paleoenvironment in the deepest portion of the inner shelf - as defined by Hayward (2010); see Figure 5.1.1.

The estimate of paleo-water depth can be further narrowed down by considering percentages present within the overall assemblage of specific key genera as shown in Hayward's Figure 86, on pg. 114. This is shown for sample 001 in Figure 5.2.6, with an estimated depth of $40 \pm 10 \mathrm{~m}$, by considering paleobathymetric proxies of percent mud and percent planktic also. For each sample, a range in water depth was calculated and all final results are in Table 5.2.3.

This sample interpretation process was completed for all samples assessed for foraminiferal content and grain size to infer paleo-environment and depositional water depth. The minimum mean value inferred for deposition is at a water depth of $31 \mathrm{~m}$. The maximum is a mean value of $61 \mathrm{~m}$. Uncertainty on all mean values is roughly $\leq$ $30 \mathrm{~m}$. This means that these proxies and methods all suggest that the samples come from sediment which was deposited at inner- to mid- depths on the paleo-marine-shelf. This is consistent with the water depths inferred from consideration of the macrofossil genera within each sample discussed earlier.

Samples 007, 009, and 011 (italics in Table 5.2.3) are considered barren of sufficient foraminifera to be statistically useful. The foraminiferal census for sample 007 totalled only 166 specimens. Microfossils in 009 and 011 were present in very low numbers and no census was carried out. Water depths inferred from these three samples are therefore of much lower quality than all others. Sample 008 is considered less representative of water depth overlying the Hautawa Shellbed at Ridge Road as the sample

Figure 5.2.6: Water depth range for sample 001/1 based on Figure 84, pg. 111 in Hayward et al. (2010). Note: logarithmic horizontal scale.

Figure 5.2.7: Faunal composition plot of all significant genera identifying paleo-water depth for sample 001/1, based on Hayward et al. (2010) Figure 86, pg. 114. 
was collected from much a poorer exposure and from sediment further from the gradational contact upper.

Table 5.2.3: Water depths in meters from all proxies measured in all samples.

\begin{tabular}{|c|c|c|c|c|c|c|c|}
\hline \multirow[b]{2}{*}{ 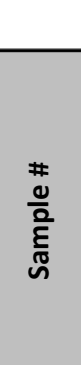 } & \multirow[b]{2}{*}{ 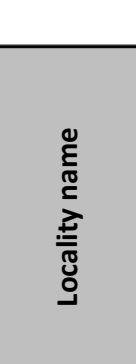 } & \multirow[b]{2}{*}{ 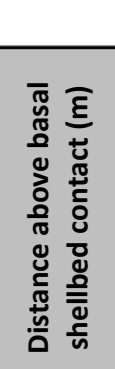 } & \multicolumn{4}{|c|}{ Methods for calculating paleo-water depth (m) } & \multirow[b]{2}{*}{ 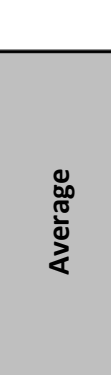 } \\
\hline & & & 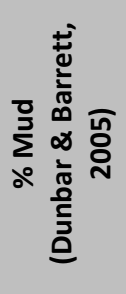 & 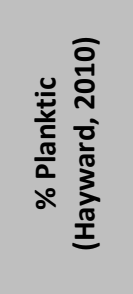 & 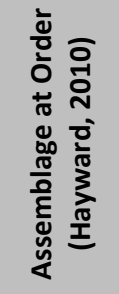 & 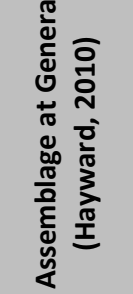 & \\
\hline 001 & Otiwhiti & +2.1 & $45 \pm 15$ & $33 \pm 20$ & $38 \pm 23$ & $40 \pm 10$ & $39 \pm 17$ \\
\hline 002 & Otiwhiti & -0.2 & $34 \pm 15$ & $28 \pm 20$ & $30 \pm 30$ & $35 \pm 15$ & $32 \pm 20$ \\
\hline 003 & West Rd & +2.85 & $35 \pm 15$ & $31 \pm 20$ & $40 \pm 30$ & $45 \pm 15$ & $38 \pm 20$ \\
\hline 004 & West Rd & -0.15 & $52 \pm 15$ & $28 \pm 20$ & $35 \pm 35$ & $40 \pm 15$ & $39 \pm 21$ \\
\hline 005 & Otiwhiti & +5.9 & $51 \pm 15$ & $41 \pm 20$ & $39 \pm 31$ & $55 \pm 15$ & $47 \pm 20$ \\
\hline 006 & Otiwhiti & +5.75 & $50 \pm 15$ & $39 \pm 20$ & $35 \pm 25$ & $45 \pm 10$ & $42 \pm 18$ \\
\hline 007 & West Rd & -0.15 & $57 \pm 15$ & - & - & - & $57 \pm 15$ \\
\hline 008 & Ridge Rd & +4 & $44 \pm 15$ & $53 \pm 20$ & $50 \pm 30$ & $53 \pm 13$ & $50 \pm 19$ \\
\hline 009 & Ridge $R d$ & -0.5 & $37 \pm 15$ & - & - & - & $37 \pm 15$ \\
\hline 010 & Colenso & -0.5 & $34 \pm 15$ & $66 \pm 20$ & $80 \pm 70$ & $63 \pm 18$ & $61 \pm 31$ \\
\hline 011 & Colenso & +5.65 & $39 \pm 15$ & - & - & - & $39 \pm 15$ \\
\hline 012 & Colenso & +5.5 & $50 \pm 15$ & $54 \pm 20$ & $80 \pm 70$ & $68 \pm 23$ & $58 \pm 32$ \\
\hline 013 & Colenso & -0.2 & $57 \pm 15$ & $69 \pm 20$ & $80 \pm 70$ & $50 \pm 20$ & $58 \pm 31$ \\
\hline 014 & Ridge Rd & +3.5 & $35 \pm 15$ & $35 \pm 20$ & $40 \pm 30$ & $40 \pm 20$ & $37 \pm 21$ \\
\hline 015 & Ridge Rd & -0.25 & $34 \pm 15$ & $28 \pm 20$ & $33 \pm 27$ & $30 \pm 25$ & $31 \pm 22$ \\
\hline
\end{tabular}

\subsection{FORAMINIFERA RESULTS}

\subsubsection{Paleo-water depth at central basin sites}

At all central Whanganui Basin sites, the proxies for paleo-water depth are well correlated [Fig. 5.3.1: A, B, C]. All of these sites show trends of slightly increasing mean water depth during deposition of the Hautawa Shellbed. This is consistent with the sequence stratigraphic interpretation that the shellbed was deposited during a marine transgression (Naish \& Kamp, 1997a). But the variation between samples and the uncertainty in calculated values means there is no strong statistic indication in this dataset of transgression. But all samples do suggest depositional environments of the deepest inner shelf to shallowest middle shelf. 
The stability of the depositional environment as remaining at similar water depths infers that influences of 1) sedimentation and shellbed accumulation, 2) basin subsidence due to back-arc pull down, and 3) transgressional water depth rise were roughly balanced. The foraminiferal data suggests that the sediments from all sites also appear to have been deposited at roughly the same water depth - around the deepest inner-shelf. This is in contrast to the suggested eastward deepening interpreted by McIntyre (2002) between the Whanganui River and Rangitikei River exposures based on macrofossil bulk assemblages. Mclntyre relied on only molluscan paleoecology, based on mostly extant species ranges, for macro-fauna contained in the Hautawa Shellbed across the basin.

This trend of nearly indistinguishable water depths may also be an issue with trying to calculate paleo-water depths from shallow water environments. Usually, planktic percentage is a simple but strong method for calculating paleo-water depth. But an enclosed, deep and sheltered basin which may have oceanic water input can produce reduced planktic percentages (Hayward, 2010). Water mixing and shelf sediment reworking complicates the derivation of distinctive paleo-water depth changes through time for sediment samples like these which were deposited on the paleo-marine shelf. This emphases the importance and value of the multi-proxy approach used here.

\subsubsection{Paleo-water depth at eastern margin site}

Analysis of foraminifera in the samples collected from sediments encapsulating the limestone at Colenso Station has generated less conclusive paleo-water depths than for samples in the central Whanganui Basin. Greater planktic percentages ( $\geq 15 \%$ ) and different benthic assemblages resulted in larger uncertainties, though the mean paleowater depths for samples were in the range of the shallowest mid-shelf [Fig. 5.3.1 D].

\subsubsection{Age range from microfaunal assemblage}

The coexistence of Globorotalia crassula and dominantly dextral G. crassaformis defines the base of the Nukumaruan Stage in deep-water environments where planktics are common, from ODP Sites 119-1125 (R. Cooper \& Agterberg, 2004). To date, only one sample from within the Hautawa Shellbed has previously contained this overlap (Hornibrook, 1981). 
Figure 5.3.1: Water depth changes observed relative to basal contact (m).

A

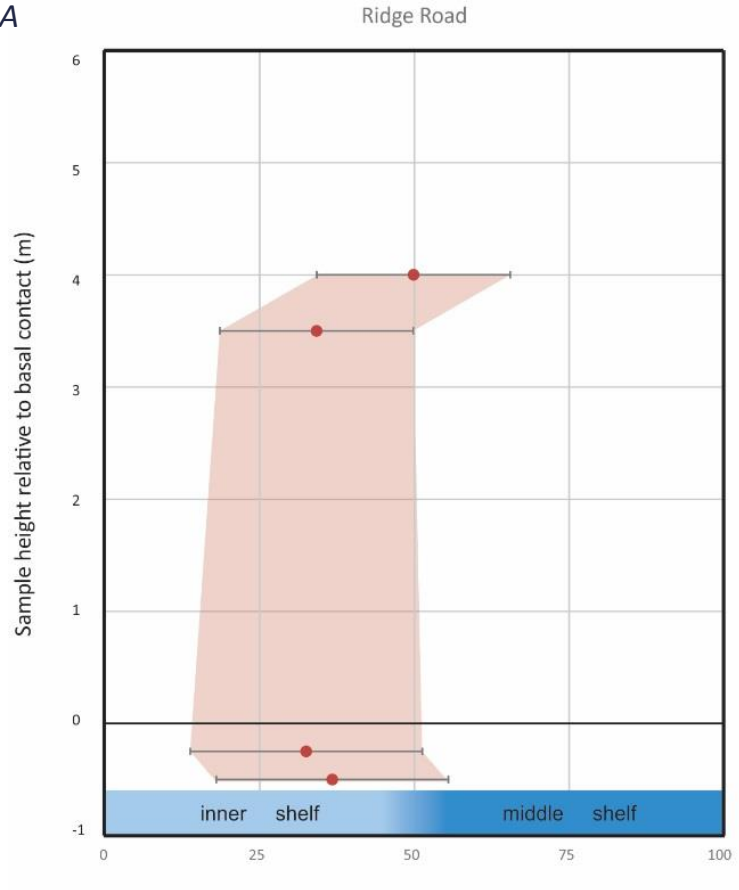

Paleo-water depth

C

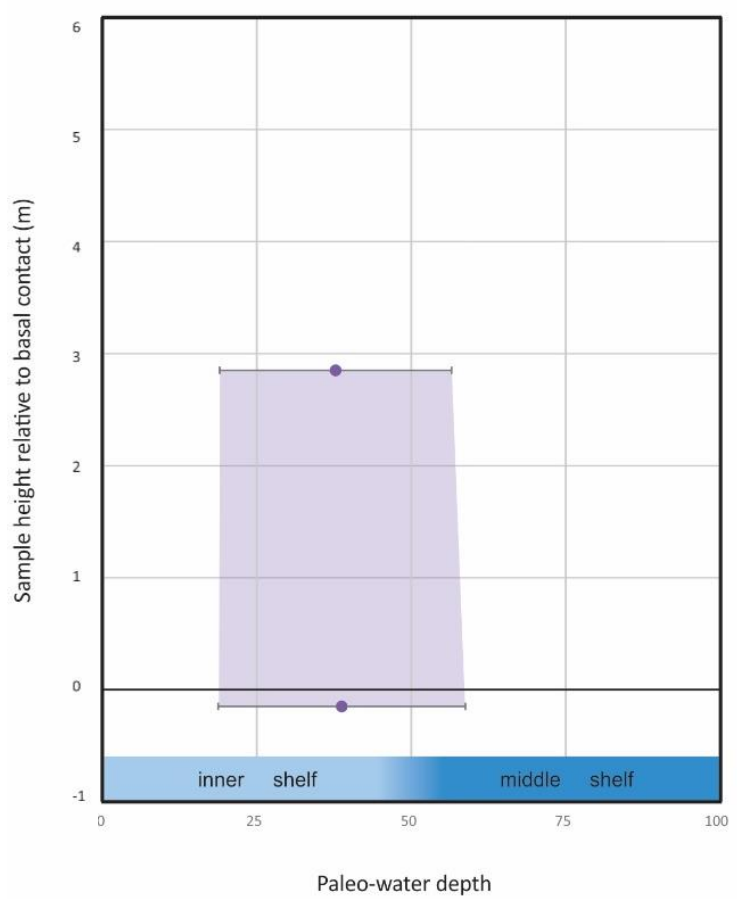

$B$

$B$

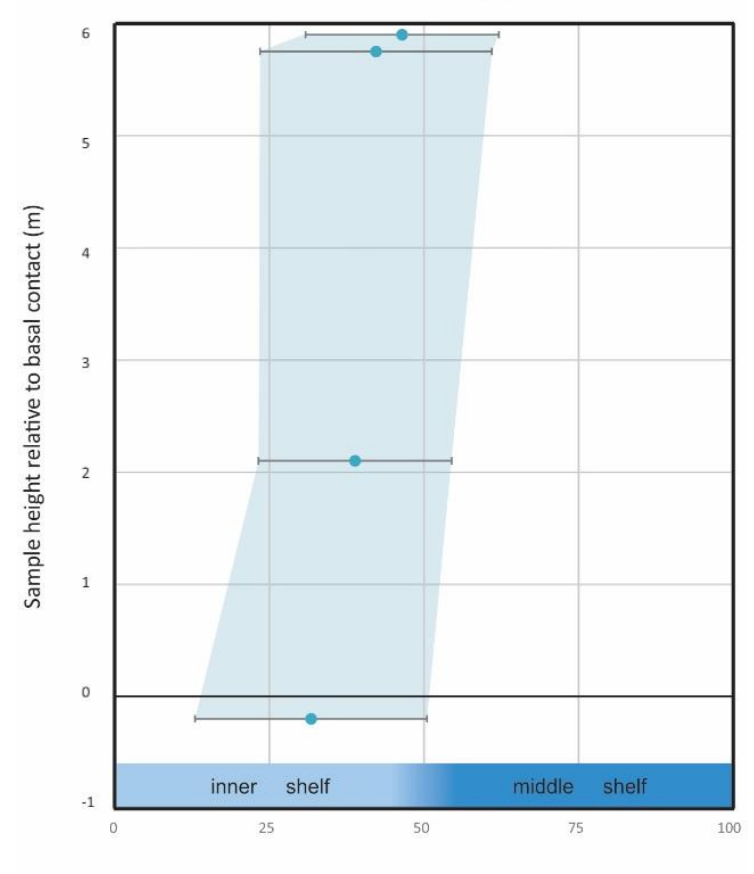

Paleo-water depth

$D$

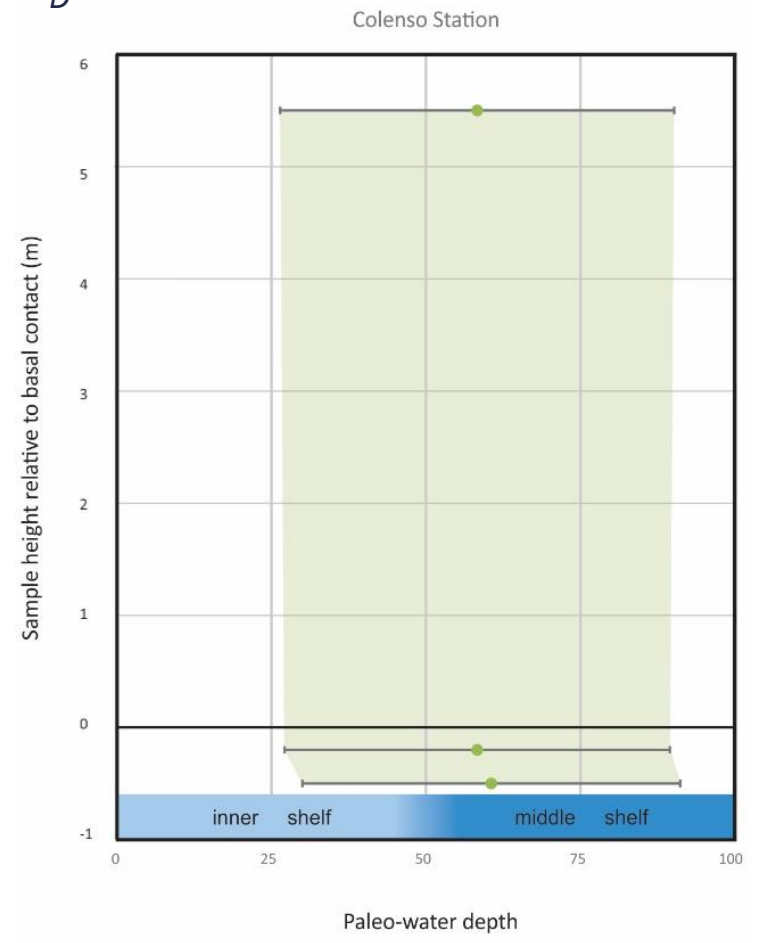


R. Cooper and Agterberg (2004) suggested that the processing of large numbers of samples from Whanganui Basin would confirm the overlap in the presence of $Z y$ gochlamys delicatula with G. crassula and dominantly dextral G. crassaformis within the Hautawa Shellbed. This has not been either proven or disproven here due to little planktics being observed in the central basin samples from siltstones encompassing the Hautawa Shellbed. Further work is required to confirm whether G. crassula and dextral G. crassaformis may overlap undeniably within the Hautawa Shellbed.

Overall, foraminifera identified within samples provide an age of Waipipian to Nukumaruan (3.60 - 1.63 Ma) [Fig. 5.3.2]. This agrees with the inference of an age of 2.40 Ma and basal Nukumaruan Stage, based on the macrofaunal assemblage presented here and with the cyclo-stratigraphic and chronologic work of others (R. Cooper \& Agterberg, 2004; Hollis et al., 2010; Naish \& Kamp, 1997b). 
Figure 5.3.2: Age range chart of key foraminifera in samples compared to both the New Zealand Geologic Timescale and species age ranges in millions of years.

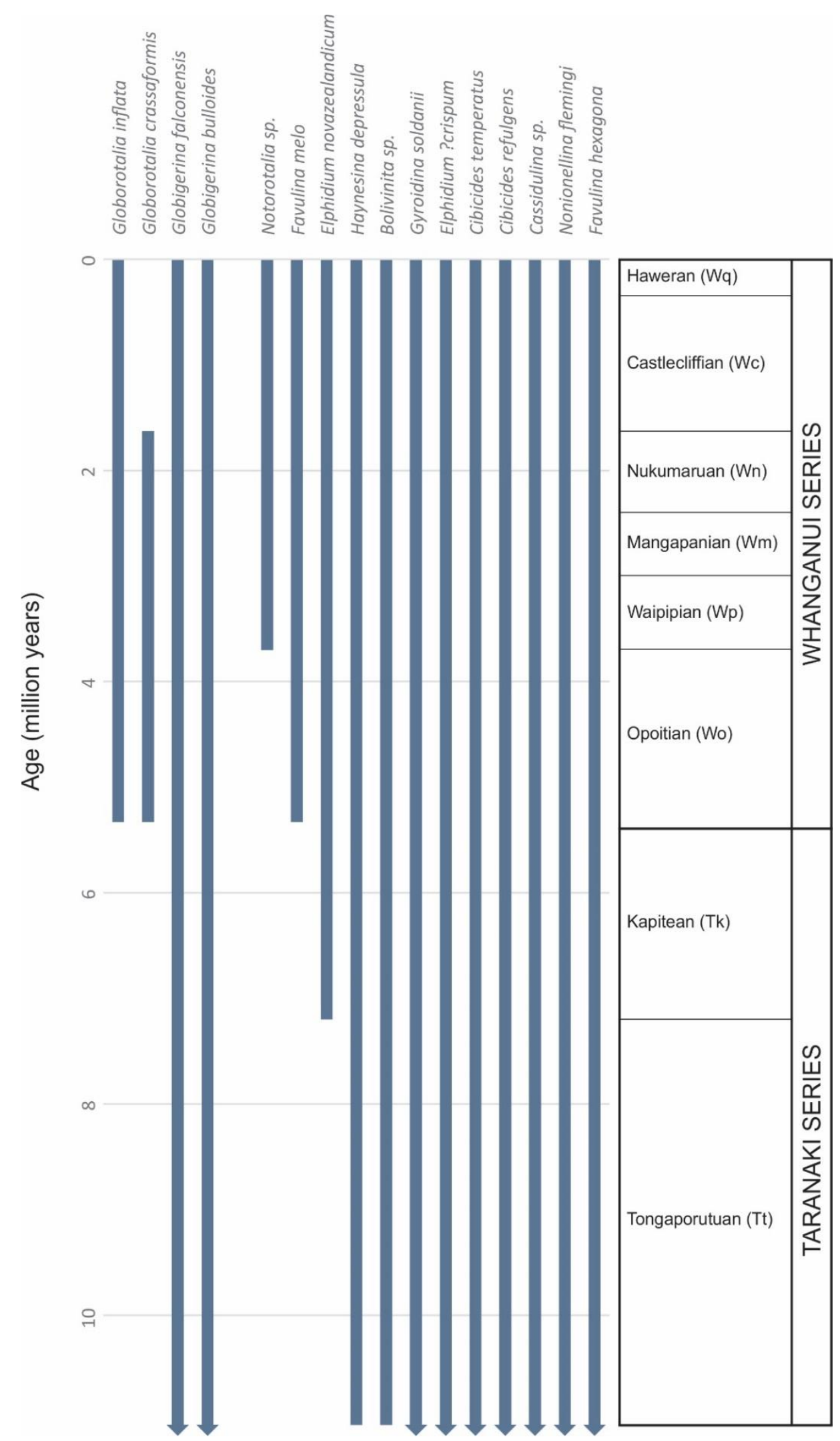


CHAPTER SIX

\section{CHAPTER SIX \\ DISCUSSION}

\subsection{INTRODUCTION}

The primary objective of this thesis is the investigation of paleoenvironmental variations, as preserved in outcrop exposures of Hautawa Shellbed, across the Whanganui Basin.

The Hautawa Shellbed, comparable to the type section on West Road representing deposition during a single transgression, is only present in the central Whanganui Basin distal from the eroding greywacke proto-Ruahine Range. Therefore, the limestone to the east proximal to the Ruahine Range is not 'Hautawa Shellbed' as plotted in the QMAP series but may be considered a stratigraphic correlative of similar age, though from a distinctive and contrasting depositional environment. The distribution of units discussed in this chapter are shown in Figure 6.1.1.

\subsection{BASAL NUKUMARUAN CORRELATIVES}

In this study, the focus has been on the central Whanganui Basin outcrops of the Hautawa Shellbed. Brief investigation of limestones situated closer to the axial Ruahine Range has also been included in this study primarily due to these previously being identified as containing Zygochlamys delicatula and Crassostrea ingens or Phialopecten triphooki (Carter, 1972; Milne, 1968).

\subsubsection{Central Basin Hautawa Shellbed}

Outcrop structure and sequence stratigraphic context

Due to the complex nature of the Hautawa Shellbed and its repeated description in literature over nearly a century, constraining the inherent variability is significant. Simple observation of the three central Whanganui Basin sites shows disparate outcrop structure [Fig. 6.2.1 A]. 

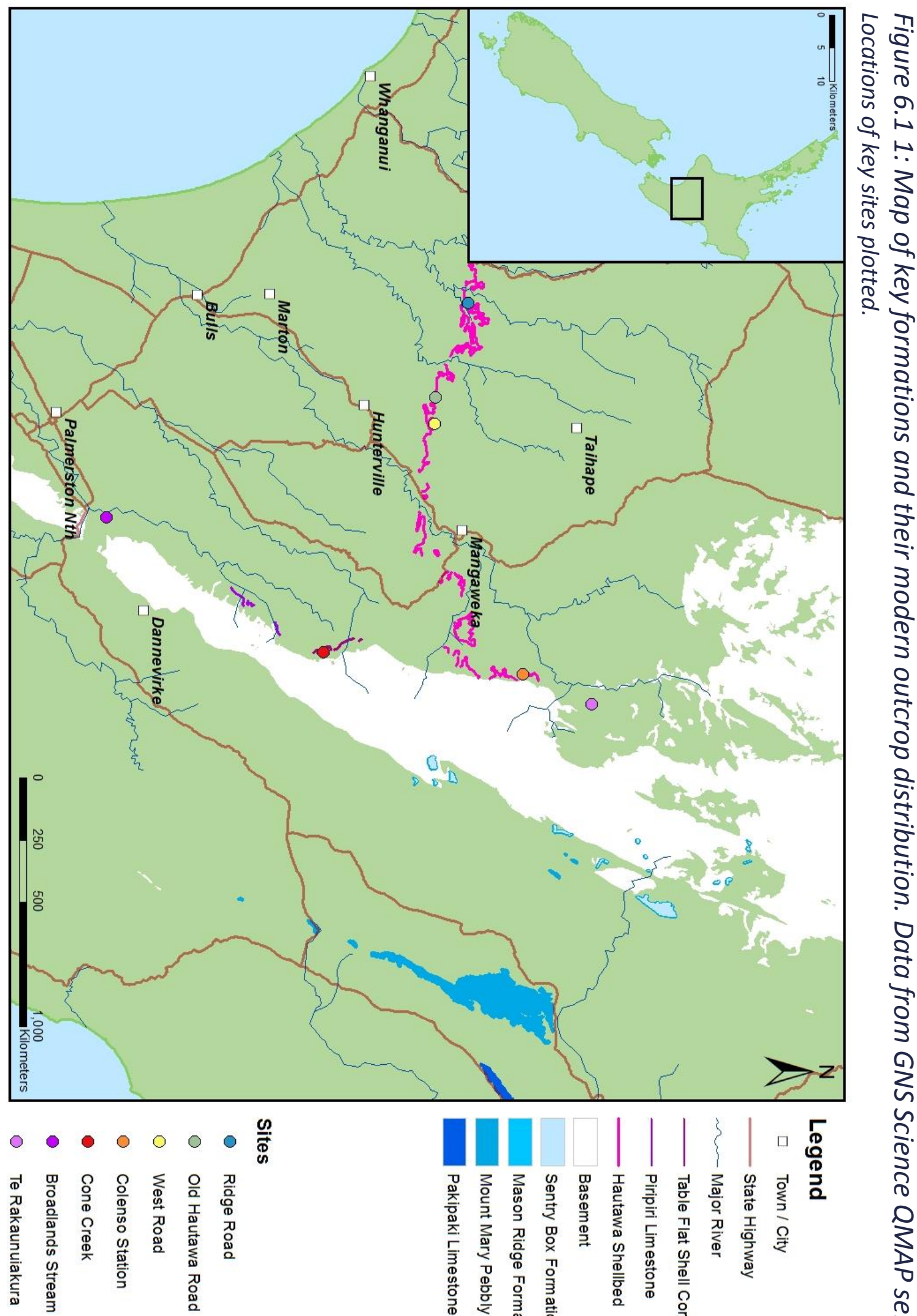

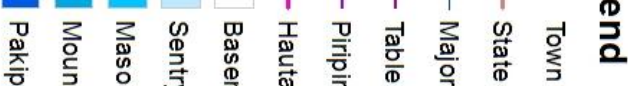

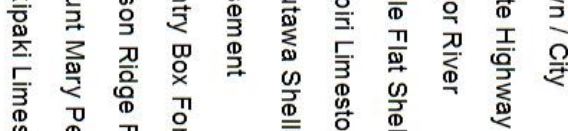

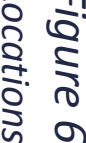
우 की $\stackrel{n}{\rightarrow}$ व 응ㅇ i 
At its type locality on West Road, as suggested by Beu (2001), the Hautawa Shellbed is a continuous, shell-rich deposit of just less than three metres thick [Fig. 6.2.1 A]. It has been described multiple times in the nearby Rangitikei Valley as compound - superimposed onlap and backlap shellbeds (Naish \& Kamp, 1995, 1997b). The shellbed has also been identified by others near Parikino (nearly 40 kilometres to the west) and here

Figure 6.2.1: Depiction of sequence stratigraphic units extrapolated between sites and the model explaining variations observed.

A: Outcrop structure variation observed in central basin sites

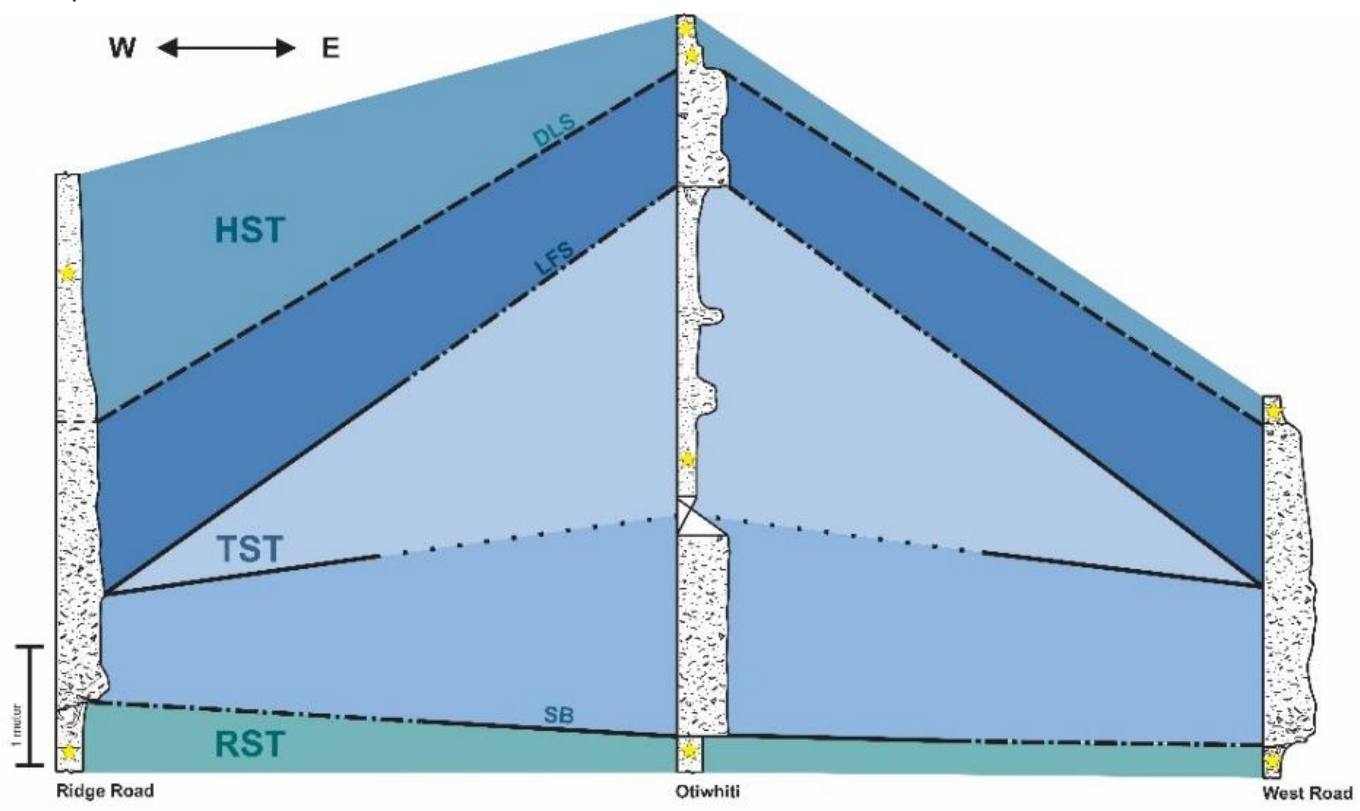

B: Model relating shelf depositional position to cyclothem motif architecture after Saul et al. (1999) and Kondo et al. (1998)

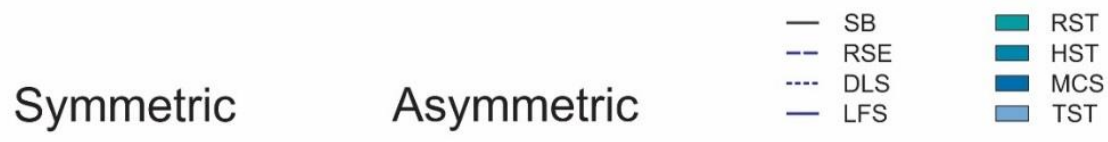

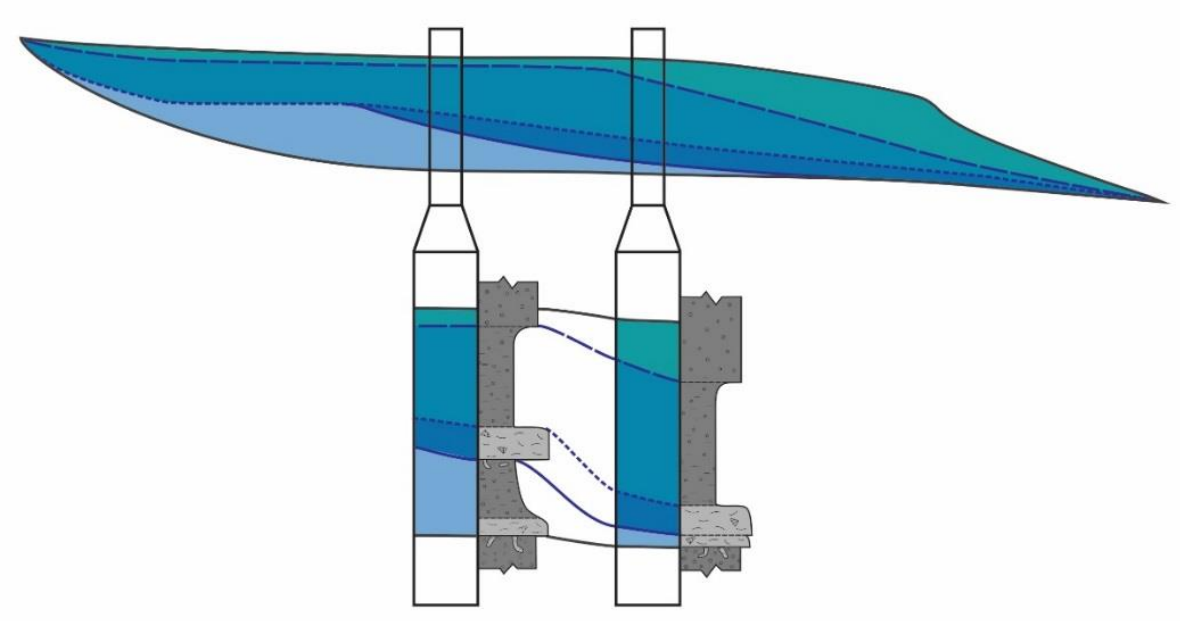


it contains a silty interval of $1.5 \mathrm{~m}$ thickness that contains no macrofossils and is hence not compound (Mclntyre \& Kamp, 1998). This contrast in outcrop structure with the type locality is also documented here at Otiwhiti Station on Old Hautawa Road.

The simple model presented in Fig. 6.2.1 B shows the two contrasting outcrop structures which have been previously described and explained as 'sequence motifs' (Kondo et al., 1998; Saul et al., 1999) (section 1.7, pg. 31). The dividing, barren silt between onlap and backlap shellbeds is appropriate as a barren silt wedge can be deposited shoreward of the compound shellbed position [Fig. 6.2.1 B]. The traditional type locality is clearly formed at the base of an asymmetric cyclothem while the new site clearly fits the expected depositional motif of a symmetric cyclothem [Fig. 6.2.1 B]. A symmetric outcrop structure has already been identified for other sequences in the Turakina Valley compared to the asymmetry of the Rangitikei so these findings are appropriate (Carter \& Naish, 1998).

This model clearly shows that a symmetric depositional motif comes from a position closer to the paleo-shoreline. This also implies that the outcrops described entail the entirety of the transgressive systems tract (TST) with the downlap surface (DLS) depicting the boundary to highstand systems tract (HST) overlying the shellbed at all locations. Interestingly, at Ridge Road, there appears to be preserved a downlap shellbed deposit also [Fig. 6.2.1 A]. When the upper shellbed outcrop becomes matrix supported it is no longer backlap in style but in downlap as observed above the Hautawa Shellbed in the Rangitikei Valley by Naish and Kamp (1997b).

The analysis of taphonomic descriptions and faunal content within three locations in the central Whanganui Basin has exposed greater variation in the Hautawa Shellbed than suggested by the compound onlap-backlap shellbed model. The analysis of both the Molluscan assemblage data and the taphonomic data presented here suggests that the shell bed is made up of three subunits that can be correlated across the basin [Fig. 3.4.2, pg. 73]. Subunits A and B appear to be equivalent to the onlap style shellbed. While subunit $\mathrm{C}$ is the overlying downlap or mid-cycle shellbed (MCS) depending on the motif observed [Fig. 6.2.1] (Saul et al., 1999). 
Understanding the sequence stratigraphic position of the shellbeds in their encompassing cyclothem helps explain the variations which are being observed laterally between sites. The asymmetric outcrop architecture observed at Ridge Road and West Road matches the Rangitikei motif described by Saul et al. (1999) [Table 6.2.1]. While the symmetric structure observed at Old Hautawa Road matches the Turakina motif (Saul et al., 1999) [Figure 6.2.1]. It is argued that the position on the paleo-shelf is the primary controller of the architecture preserved along the relationship between rate of terrigenous sediment supply and the rate of sea level change (Kondo et al., 1998; Saul et al., 1999). Therefore, the West Road and Ridge Road outcrops are expressions of a 'deeper' shelf deposition resulting in the Hautawa Shellbed, while Old Hautawa Road is a 'shallower' shelf deposit.

Table 6.2.1: Stratigraphic artitecture and sequence motif observed at key sites.

\begin{tabular}{|c|c|c|c|c|}
\hline Site & 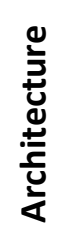 & 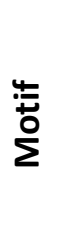 & Implications & $\begin{array}{l}\text { Implied Paleo- } \\
\text { environment }\end{array}$ \\
\hline $\begin{array}{l}\text { West Road } \\
\text { Ridge Road }\end{array}$ & 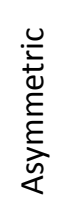 & 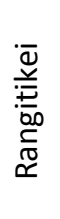 & $\begin{array}{l}\text { Deposition in an 'offshore } \\
\text { shelf' environment } \\
\text { High subsidence rate } \\
\text { Relative high water-depth } \\
\text { at highstand }\end{array}$ & Outer Shelf \\
\hline $\begin{array}{c}\text { Old } \\
\text { Hautawa } \\
\text { Road }\end{array}$ & 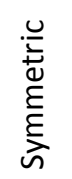 & $\frac{\sqrt{\frac{\pi}{5}}}{\frac{\sqrt{0}}{J}}$ & $\begin{array}{l}\text { Enhanced sediment sup- } \\
\text { ply } \\
\text { Controlled by proximity } \\
\text { to shelf }\end{array}$ & Inner Shelf \\
\hline
\end{tabular}

\section{Shellbed deposition interpretation}

In all cases the Hautawa Shellbed is deposited in a transgressive systems tract (TST), during marine flooding at a time of a deglaciation. The bounding surfaces of the Hautawa Shellbed are the transgressive surface of erosion (TSE) at the base and the downlap surface (DLS) at the top. The subunits which are observed to make up the shellbed $(A, B$, and $C)$ contain distinct faunal assemblages and taphonomic features. 
At the type section locality on West Road, the Hautawa Shellbed is thought to be a condensed onlap-backlap compound shellbed forming the base of an asymmetric cyclothem (Kondo et al., 1998). While in the adjacent exposure on Old Hautawa Road (4 $\mathrm{km}$ westward) the shellbed is described as a lower condensed onlap shellbed, a central terrigenoclastic sediment wedge, and an upper 'mid-cycle' or condensed backlap shellbed which forms the base of a symmetric cyclothem (Kondo et al., 1998; Saul et al., 1999).

The formation of subunit $A$, occurred during the earliest marine transgression (earliest TST) where shallower deposits are eroded and transported to mid-shelfal depths (Kondo et al., 1998). This results in a lag of shallower depth preferring fauna deposited at increased depth with sediment winnowed away. The basin wide lateral persistence $(>1000 \mathrm{~m}$ ) of this lower shellbed is consistent with the 'sediment-starved bed' of Hendy et al. (2006). The lag contains a concentration of disarticulate, larger, and primarily soft-substrate preferring fauna. For example, this concentration of disarticulated fauna is observed in Figure 6.2.2: a photo of the base of the Hautawa Shellbed at West Road.

Figure 6.2.2: Lower contact of Hautawa Shellbed at West Road site. Infilled burrows visible below. Disarticulate fauna clearly seen: Purpurocardia, Crassostrea, and Zygochlamys. Jacob staff markings every $10 \mathrm{~cm}$ for scale.

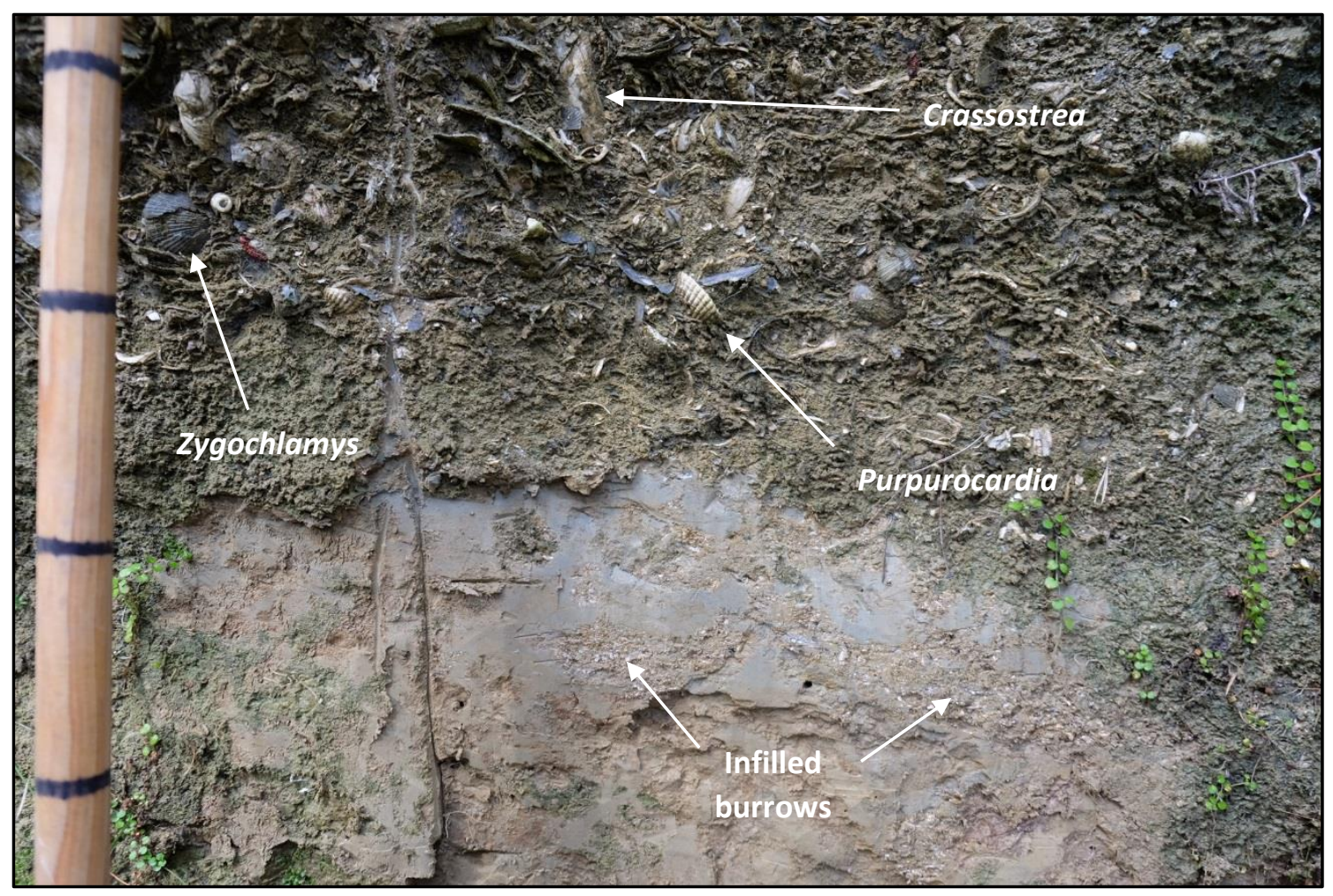


This subunit is also consistent with the expectation that a 'sediment-starved bed' will contain an infaunal bivalve dominated assemblage of brachiopods such as Neothyris and common bryozoans (Hendy et al., 2006). This is in agreement with Orpin at al. (1998) who, in a modern setting, describe the formation of a shellbed at the base of a deepening-upward succession and an overlying shellbed that forms later in the marine transgression and possibly even the early regressional phase.

The lower basal lag which formed early in the transgression builds a hard substrate which itself provides the environment to support the locally formed colonising fauna that dominated subunit $B$, with abundant bryozoans. This subunit is only observed at West Road and was established following the formation of the hard substrate forming lag. Hence, the shellbed portion is representative of reduced terrigenous sediment input to this region allowing for localised epifaunal habitat development. The localised nature $(<100 \mathrm{~m})$ of this subunit is consistent with the lateral extension expected of a 'bedform shell lag' of Hendy et al. (2006).

Subunit $\mathrm{C}$ contains a faunal assemblage completely dominated by abundant brachiopods and with a strong bryozoan presence. This part of the overall unit was deposited during the very latest phase of the transgression (latest TST) when reworking of shallow regions has been reduced due to increased water depth which can be inferred from the slightly increased water depths of dominant fauna contained and lower taphonomic signal - less jumbled mixing of large and small specimens so increased degree of sorting. Given the complete lack of articulate fauna (excluding brachiopods), this subunit has still been reworked, but to a smaller degree than subunit $A$.

\section{Other environmental constraints}

Foraminiferal assemblage water depth preferences suggest that sediments forming the overlying and intra-shellbed siltstones were deposited in an inner to midshelf setting. This shelfal location is consistent with the shellbeds supposed sequence stratigraphic position. But the implication that the symmetric architecture implies shallower shelfal position than the asymmetric outcrop structure observed at the other two sites is not apparent from the foraminiferal dataset (Kondo et al., 1998). There are no significant differences observed between the calculated water-depths for all samples in the central basin and they are statistically indistinguishable [Fig. 6.2.3]. The foraminiferal 
Figure 6.2.3: Water depths from foraminiferal assemblages. Sample positions plotted with respect to the distance above or below the basal contact of the Hautawa Shellbed at each site.

Red $=$ West Road; Blue = Old Hautawa Road; Green = Ridge Road. Wavy line emphasises position of basal unconformity in the sections.

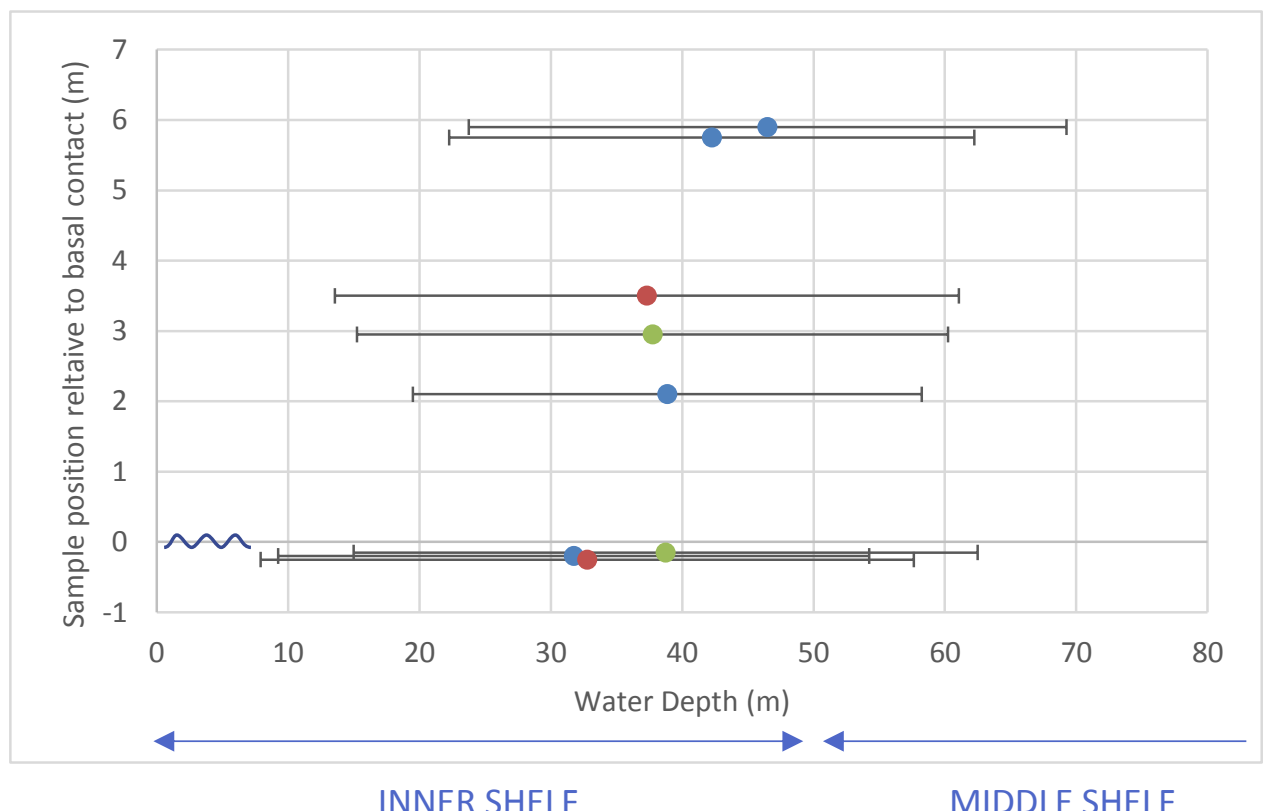

assemblages in the samples suggest the environment of inner shelf to shallowest middle shelf (Hayward, 2010). This is consistent with the water depth ranges inferred for deposition of the Hautawa Shellbed subunits based on mollusc assemblages.

The gently undulating, and rapidly gradational or semi-erosive contact at the base of the shellbed [e.g. Fig. 6.2.2] implies a break in sedimentation between the silt below and the shellbed itself, and also the possible erosion of any shallow depositional facies that may have been deposited during the prior regressive systems tract. This also suggests there may have been significant time for relative sea level change between deposition of the silt beneath and the shellbed itself.

Previously, the Hautawa shellbed in the Rangitikei River is thought to have been deposited in a comparatively deep setting on the outer shelf (Orpin et al., 1998). While the Rangitikei section is further eastward than sites assessed here, hence is closer to the Pliocene basin depocentre (Nicol, 2011), this does not match the paleo-water depth inferred from samples assessed here of deepest inner shelf. 
Age

As shown in Table 1.6.1, a basal Nukumaruan age is assigned to the Hautawa Shellbed due to the first occurrence in Whanganui Basin of Zygochlamys delicatula and Nukumaruan Phialopecten triphooki and the last occurrence of the generally Mangapanian restricted fauna Crassostrea ingens and Phialopecten thomsoni. No evidence presented here refutes this status.

The foraminiferal assemblage identified, collected from sediments encompassing the Hautawa Shellbed, infers an age of Waipipian to Nukumaruan (3.70-1.63 Ma). Due to the lack of Globorotalia crassula in any samples, it is not possible here to confirm the suggestion of R. Cooper and Agterberg (2004) discussed earlier for the Hautawa Shellbed and base of the Nukumaruan Stage. They suggested that processing many samples from the interval of the Hautawa Shellbed could produce a large enough planktic assemblage to provide irrefutable evidence of the overlap between Globorotalia crassula, Globorotalia crassaformis, and the first arrival of Zygochlamys delicatula into Whanganui Basin at this time.

\subsubsection{Colenso Station, east of Taihape}

This limestone, observed near the Ruahine Range at the north-eastern corner of Whanganui Basin, emphasises the significance in outcrop variation between contrasting depositional environments within a basin at the same time. A measured section of this unit is presented as Section A, Enclosure 4. The thick $(>6 \mathrm{~m}$ ) pebbly, Tawera dominated limestone observed at Colenso Station is visually very different to the $3 \mathrm{~m}$ compound form silty, diverse Hautawa Shellbed observed in the central Whanganui Basin [Fig. 6.2.4]. These deposits are strongly linked through the presence Zygochlamys delicatula and Crassostrea ingens in both sections (J. Lee et al., 2011).

Zygochlamys delicatula is only observed in the Whanganui Basin in two cyclothems: primarily in the Hautawa Shellbed and also in the consecutive marine transgression in the Tuha Shellbed (Orpin et al., 1998). Therefore, the limestone at Colenso Station must be an age-equivalent correlative to one of if not both of these shellbeds. The presence of Crassostrea fragments suggest the older Hautawa Shellbed to be more 
likely. This limestone also contains greywacke pebbles - evidence of this sites' proximity to basement with the uprising and erosion of the axial proto-Ruahine Range.

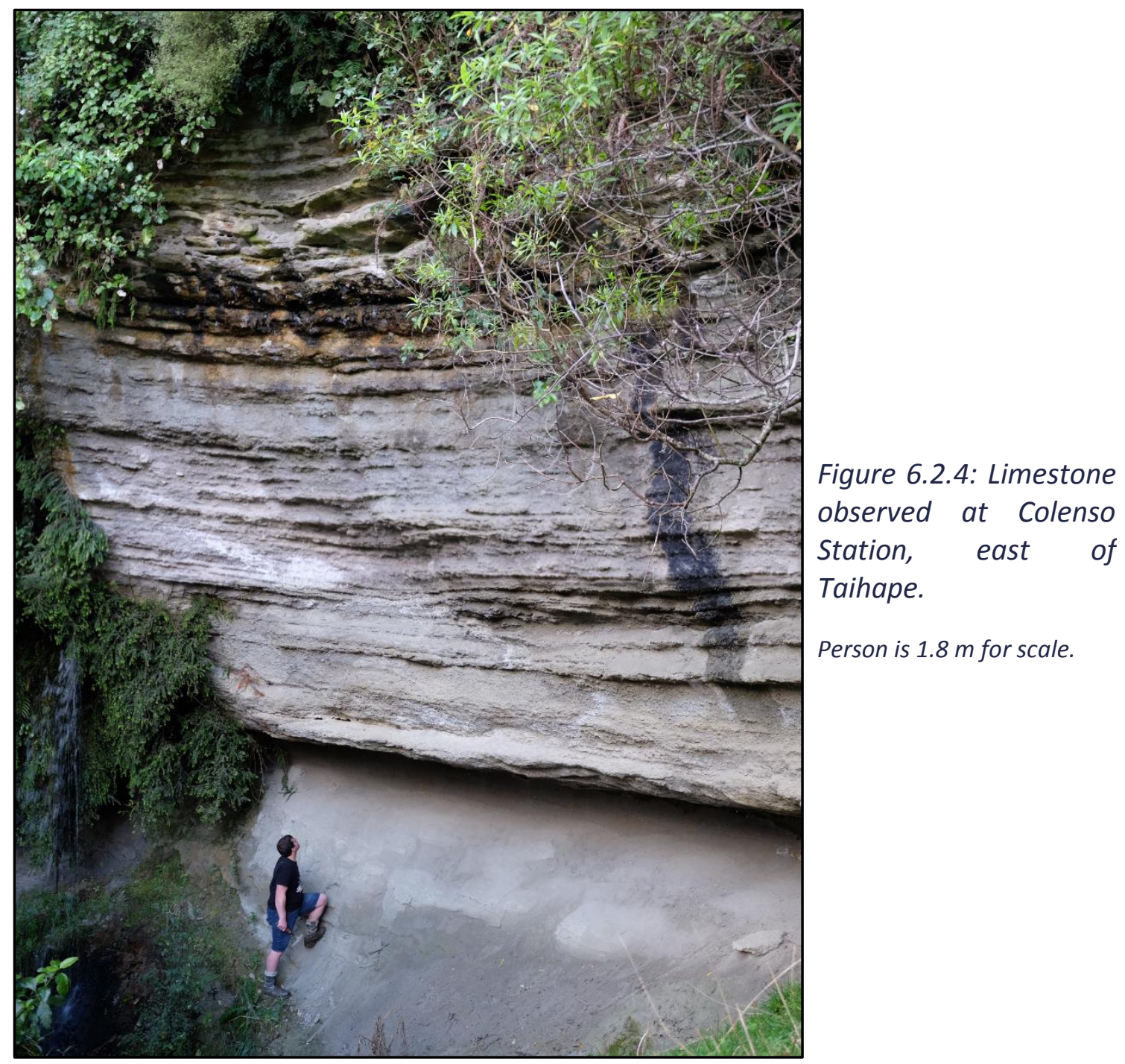

Age

Generally, the presence of Zygochlamys alone is considered to be significant enough to imply an early Nukumaruan age for any Whanganui Basin unit. The fragments of Crassostrea ingens help confirm that this limestone is probably of correlative age to the Hautawa Shellbed in the central basin and hence also of the Tikapu Formation.

\section{Environment constraints}

Sediment samples collected here $(010,013$ and 012$)$ contained a contrasting foraminiferal assemblage to all the central basin samples. Primarily, the dissimilarity was driven by the planktic content being far larger than in other samples (they have the three highest recorded planktic \% values). The presence of more planktic specimens may also 
be a function of proximity to deeper water compared to in the central Whanganui Basin [Fig. 6.2.5].

The planktic content is mostly made up by Globigerina bulloides and Globorotalia crassaformis with Orbulina universa also present. Interestingly, G. crassaformis is dominantly dextral for all three samples $(87 \%, 100 \%$, and $100 \%$ in 010,012 , and 013 ; respectively). While the central basin samples all had mean water depth values less than $50 \mathrm{~m}$ (and most less than $40 \mathrm{~m}$ ) all samples from Colenso Station have averages closer to $60 \mathrm{~m}$. But due to uncertainty in the water depth calculations, all samples assessed are also statistically indistinguishable.

Figure 6.2.5: Water depths from foraminiferal assemblages. Sample positions plotted with respect to the distance above or below the basal contact of the Limestone at Colenso Station, east of Taihape.

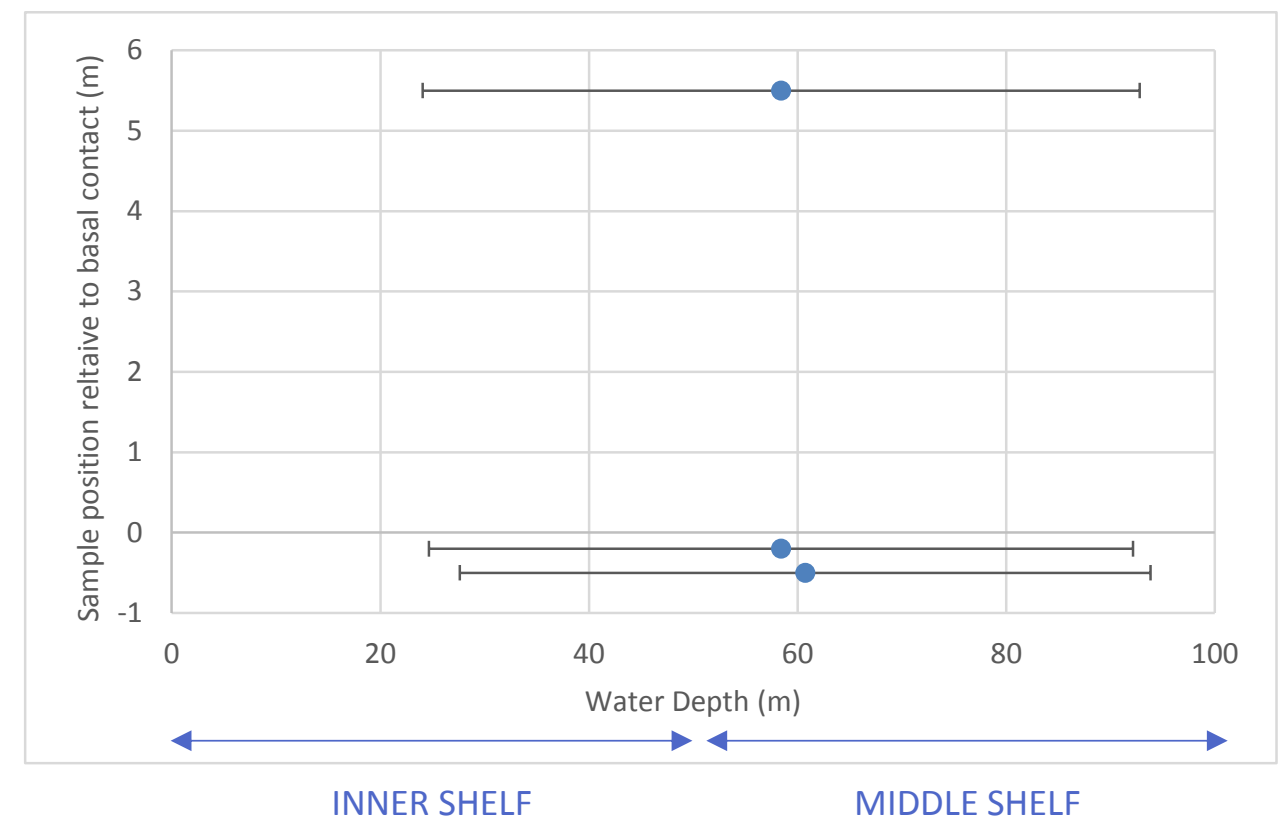

\subsubsection{Table Flat Shell Conglomerate; Cone Creek, east of Apiti}

As with the limestone at Colenso Station, the limestone observed at Cone Creek again emphasises how sedimentary preservation is controlled by environmental conditions such as sediment supply. The proximity to the rising greywacke dominated protoRuahine Range provided large numbers of pebbles into this limestone. The proportion of pebbles is great enough that this unit has been called a 'shell conglomerate' by previous workers (Milne, 1968). During reconnaissance level field work, three key species of importance to this study were seen the Table Flat Shell Conglomerate: Zygochlamys 
delicatula, Crassostrea ingens, and Phialopecten triphooki. The unit is quoted as 25 feet thick which is equivalent to ca. 7.6 meters (Milne, 1968) though it was observed as greater than 10 meters in the prominent escarpment between Cone and Coal Creek but no total thickness measurement was undertaken.

Age

As with all other units considered in this study, the limestone at Cone Creek is considered to be of an age equivalent to the Hautawa Shellbed in the central Whanganui Basin. In particular, due to the presence of Phialopecten triphooki a short lived, terminal species of the genus restricted to the early Nukumaruan (A. G. Beu, 1995). Zethalia zelandica in the friable sandy unit directly beneath the limestone also supports the interpreted age of the early Nukumaruan Stage. A bulk sample was collected from one bed [Fig. 6.2.6] and identification confirmed by Dr Alan Beu, GNS Science of Z. zelandica.

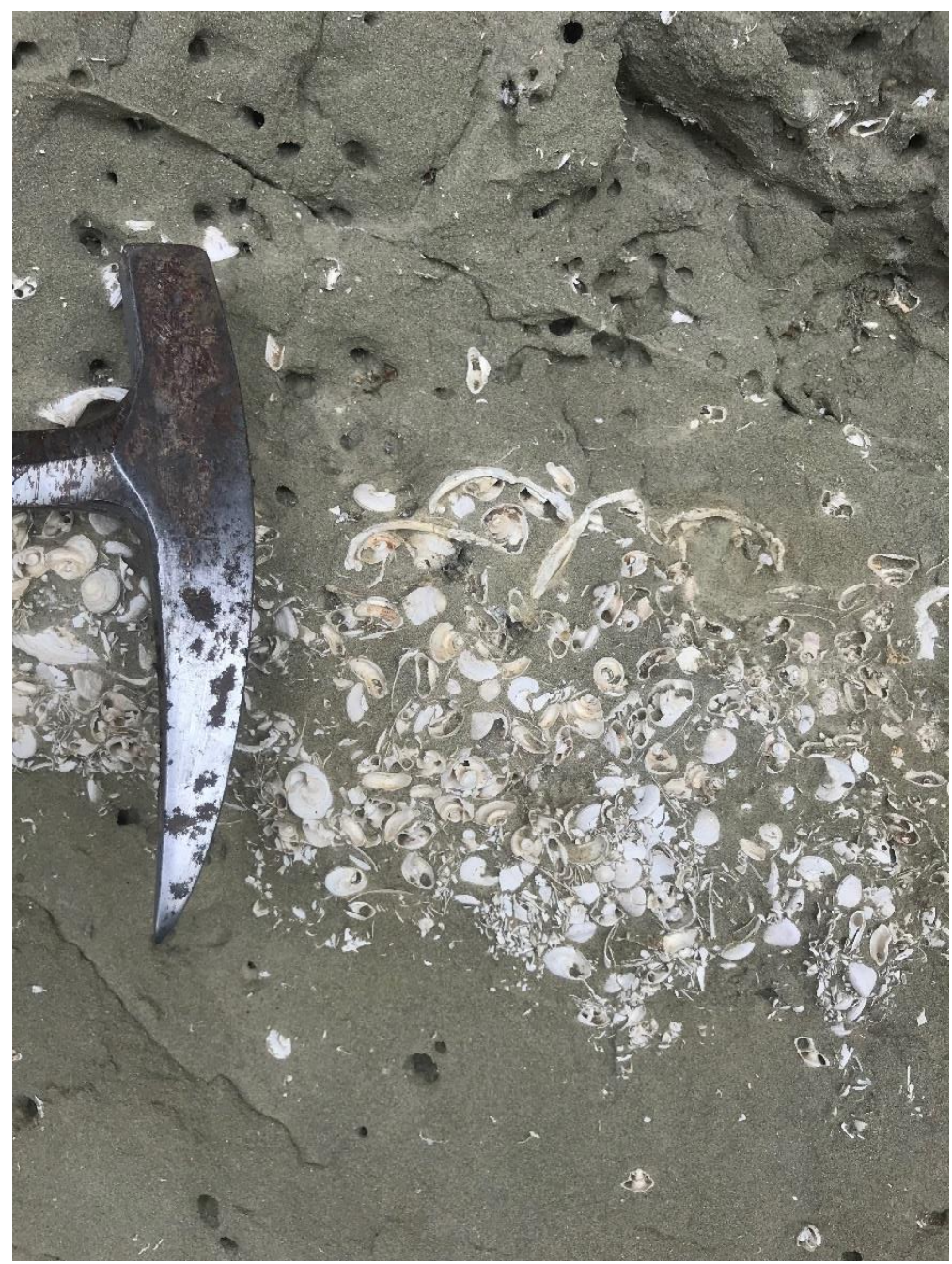

Figure 6.2.6: Zethalia zelandica within a friable sand matrix found in beds below limestone on ridge between Cone and Coal creeks. 


\section{Environmental constraints}

Milne (1968) considered the Table Flat Shell Conglomerate to have been deposited in 'inner neritic to littoral' environments. This is consistent with the observed presence of Zethalia zelandica below the unit in this study and the high concentrations of sub-rounded greywacke pebbles within the unit. The high proportion of pebbles emphasises the proximity of the Ruahine Range eroding into the marine setting preserved here. Therefore, the Table Flat Shell Conglomerate is an age equivalent deposit to the Hautawa Shellbed but from a contrasting environment.

\subsection{PALEOGEOGRAPHIC RECONSTRUCTION}

\subsubsection{Methodology}

Reconstruction of the paleogeography of the Whanganui Basin at the base of the Nukumaruan Stage is complicated by the both the amount of outcrop available for study and the varying amount of research effort that has been carried out. Correlation to the East Coast Basin is primarily based on the presence of Z. delicatula and other late Mangapanian or early Nukumaruan indicator species being present in particular units such as the Sentry Box Limestone and Mount Mary Pebbly Limestone. Orpin et al. (1998) argued that Zygochlamys delicatula is only an indicator of the base of the Nukumaruan Stage in the Hautawa Shellbed type area. In order to overcome this, the majority of formations considered as early Nukumaruan correlatives in this study also contain Nukumaruan Phialopecten triphooki along with the overlap with Mangapanian restricted Crassostrea ingens and Phialopecten thomsoni.

For example, the Piripiri Limestone is considered here to be an early Nukumaruan correlative due to containing key fauna: Zygochlamys delicatula, Phialopecten triphooki, Patro undatus (Carter, 1972). While Carter has not recorded the presence of either Phialopecten thomsoni or Crassostrea ingens, Z. delicatula's known limited occurrence interval in the Whanganui Basin implies age of earliest Nukumaruan for the Piripiri Limestone. 
Table 6.3.1 summarises the presence of key fauna found in formations of interest around the central North Island of New Zealand and the age inferred. These formations were chosen based on fauna contained and from discussion with Dr Kyle Bland, GNS Science. Most can be designated earliest Nukumaruan [Basal Wn; Table 6.3.1]. The Piripiri Limestone and Mason Ridge Formations currently are based on the known fauna, of early Nukumaruan age, but not necessarily earliest. The Mt Mary Pebbly Limestone is

Table 6.3.1: Chart of key fauna known to be present in formations and the age range inferred.

\begin{tabular}{|c|c|c|c|c|c|c|c|c|}
\hline Unit & Basin & 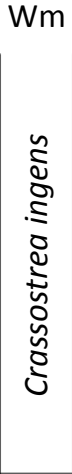 & 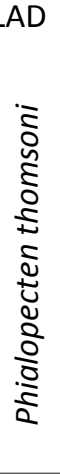 & 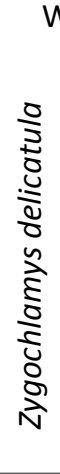 & 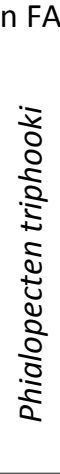 & 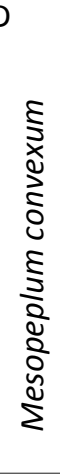 & Infers & References \\
\hline $\begin{array}{l}\text { Hautawa } \\
\text { Shellbed }\end{array}$ & $\begin{array}{l}\text { Whanganui } \\
\text { (central) }\end{array}$ & & & & & & Earliest Wn & $\begin{array}{c}\text { Fleming (1953); Beu (1969); } \\
\text { Orpin et al. (1998); } \\
\text { Mclntyre (2002); this thesis }\end{array}$ \\
\hline $\begin{array}{l}\text { Seconds Ridge } \\
\text { Conglomerate } \\
\end{array}$ & $\begin{array}{c}\text { East Coast } \\
\text { (north west) }\end{array}$ & & & & & & Earliest Wn & $\begin{array}{c}\text { Beu (1995); } \\
\text { Bland et al. (2007) }\end{array}$ \\
\hline $\begin{array}{c}\text { Kuranui } \\
\text { Limestone }\end{array}$ & $\begin{array}{l}\text { Whanganui } \\
\text { (western) }\end{array}$ & & & & & & Earliest Wn & McIntyre (2002) \\
\hline $\begin{array}{l}\text { Pakipaki Lime- } \\
\text { stone }\end{array}$ & $\begin{array}{l}\text { East Coast } \\
\text { Basin } \\
\text { (central) }\end{array}$ & & & & & & Earliest Wn & Beu $(1999,1995)$ \\
\hline $\begin{array}{c}\text { Table Flat } \\
\text { Shell } \\
\text { Conglomerate }\end{array}$ & $\begin{array}{l}\text { Whanganui } \\
\text { (eastern) }\end{array}$ & & & & & & Earliest Wn & $\begin{array}{l}\text { Milne (1968); } \\
\text { this thesis }\end{array}$ \\
\hline $\begin{array}{c}\text { Te Apiti } \\
\text { Conglomerate }\end{array}$ & $\begin{array}{l}\text { Whanganui } \\
\text { (eastern) }\end{array}$ & & & & & & Earliest Wn & $\begin{array}{c}\text { Rees et al. }(2018 a, b) \\
\text { this thesis }\end{array}$ \\
\hline $\begin{array}{l}\text { Sentry Box } \\
\text { Formation }\end{array}$ & $\begin{array}{c}\text { East Coast } \\
\text { (north west) }\end{array}$ & & & & & & Earliest Wn & $\begin{array}{c}\text { Beu (1995); } \\
\text { Bland et al. (2007) }\end{array}$ \\
\hline $\begin{array}{l}\text { Unnamed } \\
\text { Limestone }\end{array}$ & $\begin{array}{l}\text { Whanganui } \\
\text { (eastern) }\end{array}$ & & & & & & Earliest Wn & $\begin{array}{l}\text { Lee et al. (2011); } \\
\text { this thesis }\end{array}$ \\
\hline $\begin{array}{c}\text { Piripiri } \\
\text { Limestone }\end{array}$ & $\begin{array}{l}\text { Whanganui } \\
\text { (eastern) }\end{array}$ & & & & & & Early Wn & $\begin{array}{l}\text { Carter (1972); } \\
\text { Lee et al. (2011) }\end{array}$ \\
\hline $\begin{array}{l}\text { Mason Ridge } \\
\text { Formation }\end{array}$ & $\begin{array}{l}\text { East Coast } \\
\text { Basin } \\
\text { (central) }\end{array}$ & & & & & & Early Wn & Bland et al. (2007) \\
\hline $\begin{array}{l}\text { Mt Mary } \\
\text { Pebbly } \\
\text { Limestone }\end{array}$ & $\begin{array}{l}\text { East Coast } \\
\text { (north west) }\end{array}$ & & & & & & Wn & $\begin{array}{c}\text { Beu (1995); } \\
\text { Bland et al. (2007) }\end{array}$ \\
\hline
\end{tabular}


thought to be of similar age to the Sentry Box Formation as both are overlain by Esk Mudstone (Bland, Kamp, \& Nelson, 2007). But as no diagnostic fauna (either Zygochlamys delicatula or Phialopecten triphooki) have been collected from it yet, it remains as Nukumaruan in age only.

Recent research in the region of the Manawatu Saddle Road by others has been incorporated also into the findings of this thesis in order to strongly link the paleogeography of Whanganui Basin with the Manawatu Strait (Milner, 2017; Rees, 2015; Rees, Palmer, \& Palmer, 2018a, 2018b). In particular, the work describing the Te Apiti Conglomerate infers the presence of a paleo-river system entering the south-eastern Whanganui Basin during the early Nukumaruan (Rees et al., 2018a).

Rees et al. (2018a) claimed that the absence of Zygochlamys delicatula in their Te Apiti conglomerate was due to the shallow marine environment on the western Manawatu Strait at this time. While Rees et al. (2018a) are able to link the influx of gravel and loss of warm fauna (Crassostrea ingens and Phialopecten triphooki) to the climatic cooling during the early Nukumaruan, the defining stage indicator scallop Zygochlamys delicatula (Hollis et al., 2010), is missing from their faunal assemblage documented from the Te Apiti Conglomerate. Evidence presented here [Fig. 6.3.1], suggests that Z. delicatula was in fact present at this time here in the vicinity of the Manawatu Saddle Road.

Figure 6.3.1: Zygochlamys delicatula with geologic hammer for scale. Located by JEGE in conglomeratic beds in Broadlands Stream. Identification validated in the field by Dr Katie Collins.

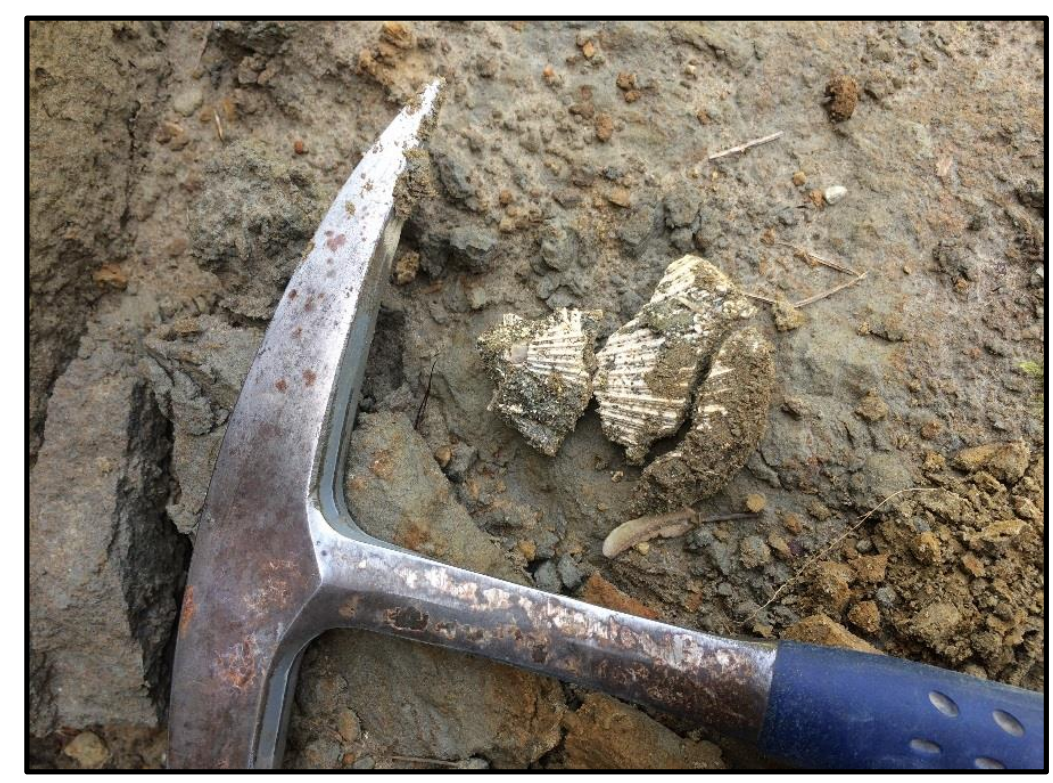


This specimen was found in Broadlands Stream during field work carried out by Milner (2017) [Fig. 6.3.1]. These correlations to the East Coast Basin allow for a fuller picture of the paleogeography at the basal Nukumaruan than can be implied based on the outcrops in the central Whanganui Basin.

\subsubsection{New paleogeography}

There are three main sources that inform the paleogeography presented here: the Early Pleistocene map of Trewick and Bland (2012), the Base Nukumaruan map of Bland et al. (2008), and both the Mangapanian and Nukumaruan-Castlecliffian maps of Strogen (2011). The reconstruction is presented in Figure 6.3.2.

The presence of 'open' Kuripapango, Manawatu, and Ruataniwha Straits at this time is a significant feature of this reconstruction. This is supported by the presence of Zygochlamys delicatula and other key fauna in conglomeratic beds in the Manawatu Saddle region in the south and also present in units near the Gentle Annie Road to the north (Browne, 2004b). The positions of nearly all rivers and catchments are generalised. The presence of greywacke pebbles in many of the basal Nukumaruan marine units emphasises that there must have been exposed and eroding basement highs proximal to those locations at this time. A provenance study of these pebbles may be able to infer
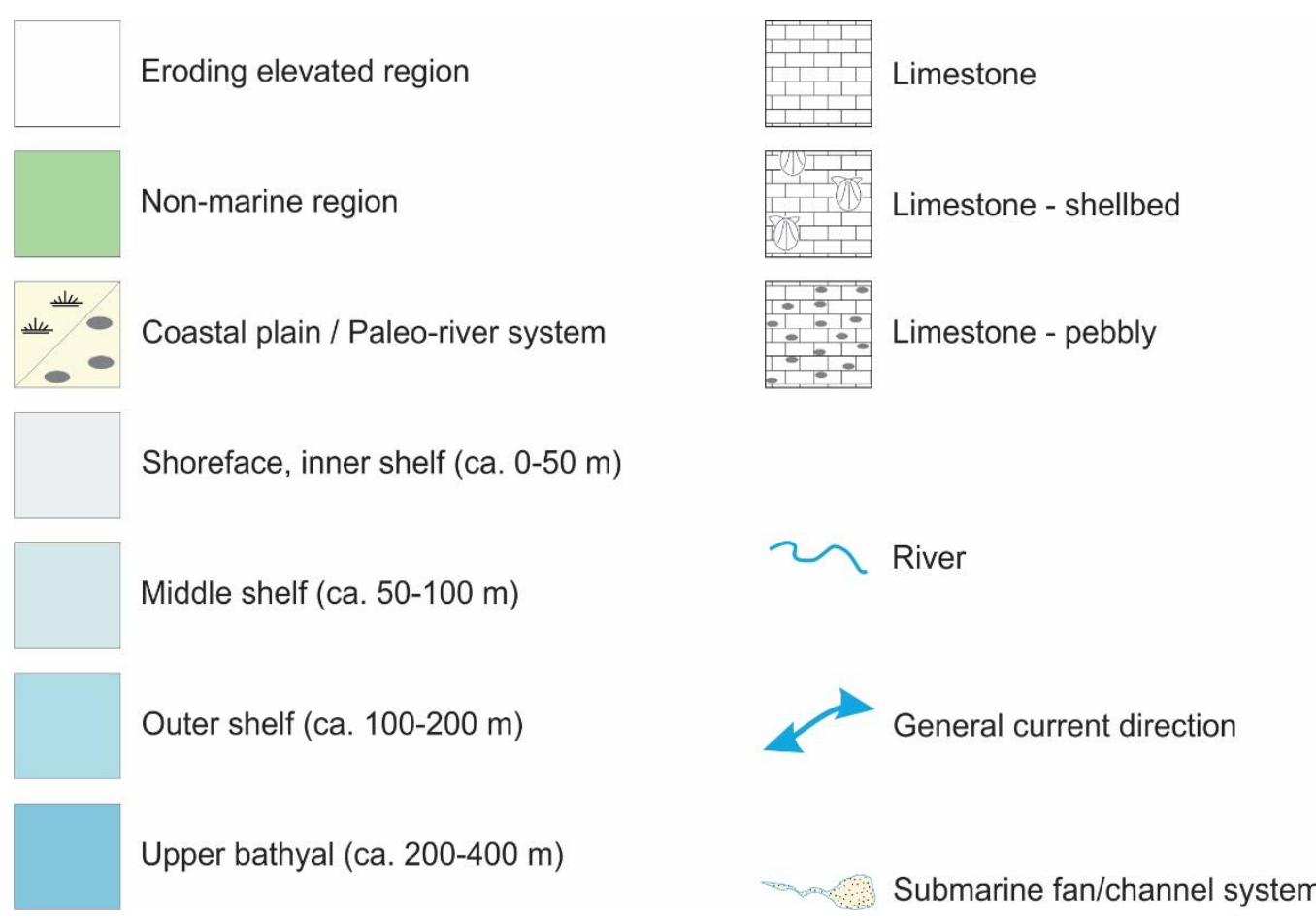
Figure 6.3.2: Central New Zealand paleogeographic reconstruction of earliest Nukumaruan Stage. Key on opposing page.
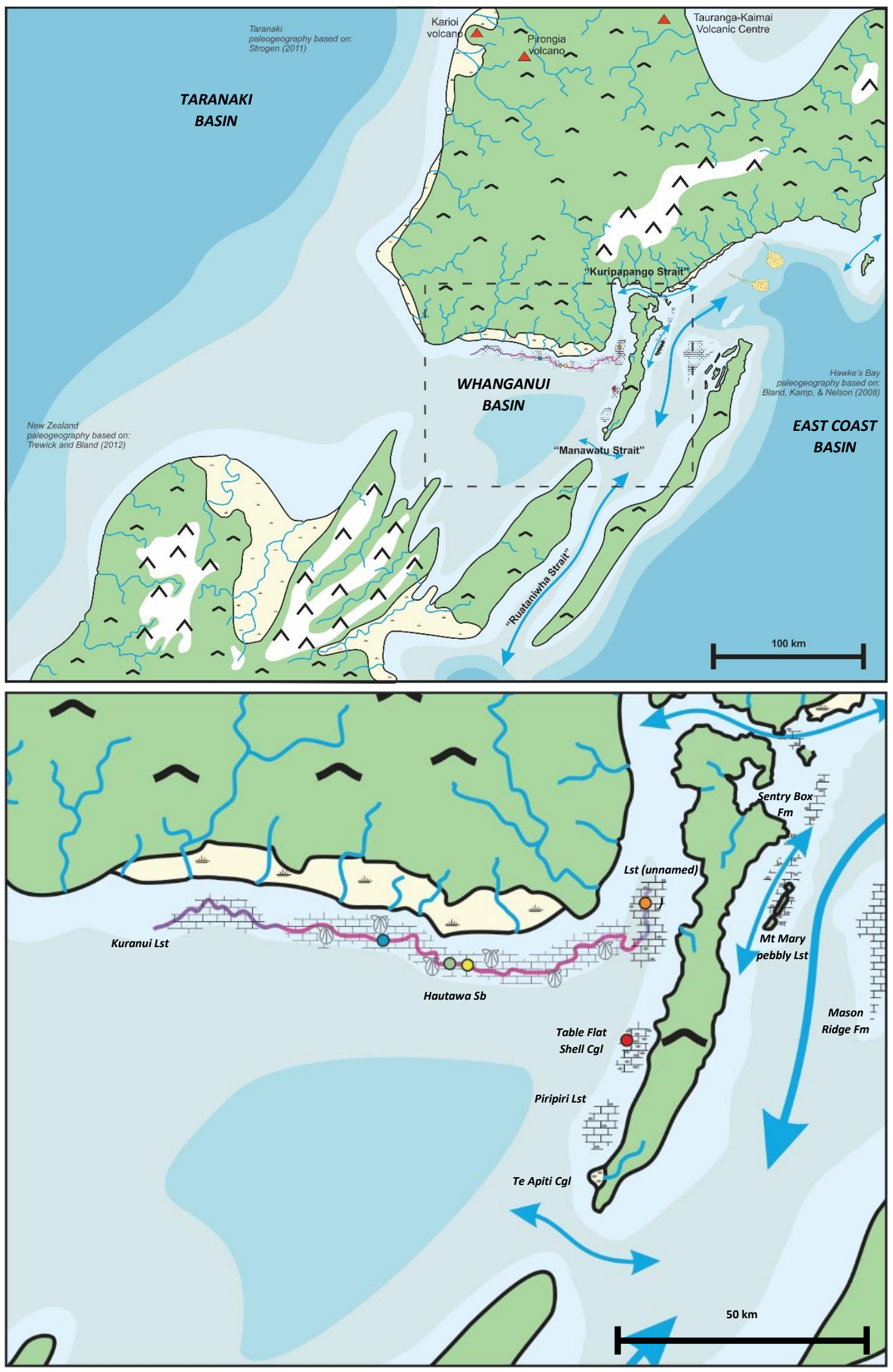
in greater detail the source rock for these basement pebbles in the future. The Te Apiti Conglomerate provides the only direct evidence of a paleo-river inferred in this reconstruction.

The contrast in outcrop structure of the Hautawa Shellbed in the central basin has been incorporated into the reconstruction by reducing the distance between paleoshoreline and modern outcrop position as described above (section 6.2.1). This applies to two locations: proximal to the township of Parikino in the modern Whanganui River valley and the Old Hautawa Road site, at Otiwhiti Station. At both sites the upper portion of the Hautawa Shellbed is preserved as a mid-cycle shellbed overlying a barren siltstone and hence these locations are positioned closer to the paleo-shoreline (McIntyre \& Kamp, 1998).

A key feature to note in this reconstruction is the inclusion of a simplified outcrop trace for the Hautawa Shellbed unit as plotted in GNS Science' QMAP series. Importantly, this trace has been divided here into three segments: dark purple for Kuranui Limestone, magenta for Hautawa Shellbed, and lilac for the unnamed limestone at Colenso Station [Fig. 6.3.2]. The QMAP series maps all these units as 'Hautawa Shellbed' but here they are considered too contrasting to the type locality on West Road to be called Hautawa Shellbed.

The greywacke pebbles are restricted to limestone deposits closer to the protoRuahine range (such as the Table Flat Shell Conglomerate and Sentry Box Formations) [Fig. 6.3.3]. Hence, the lack of these pebbles is a significant characteristic which makes the Hautawa Shellbed distinct from the limestones found along the axial Ruahine Range at Colenso Station [lilac; Fig. 6.3.2].

As discussed earlier, the relationship between the Hautawa Shellbed and the Kuranui Limestone to the west is inconclusive in prior work (Fleming, 1953; Mclntyre, 2002). Therefore, it is considered to be a completely separate lithostratigraphic unit, but perhaps of age equivalent deposition as with the unnamed limestone unit investigated at Colenso Station to the east. 
Figure 6.3.3: Abundant greywacke pebbles present in both Sentry Box Formation [upper photo, sourced from Lee et al. (2011)] and Table Flat Shell Conglomerate [lower photo].
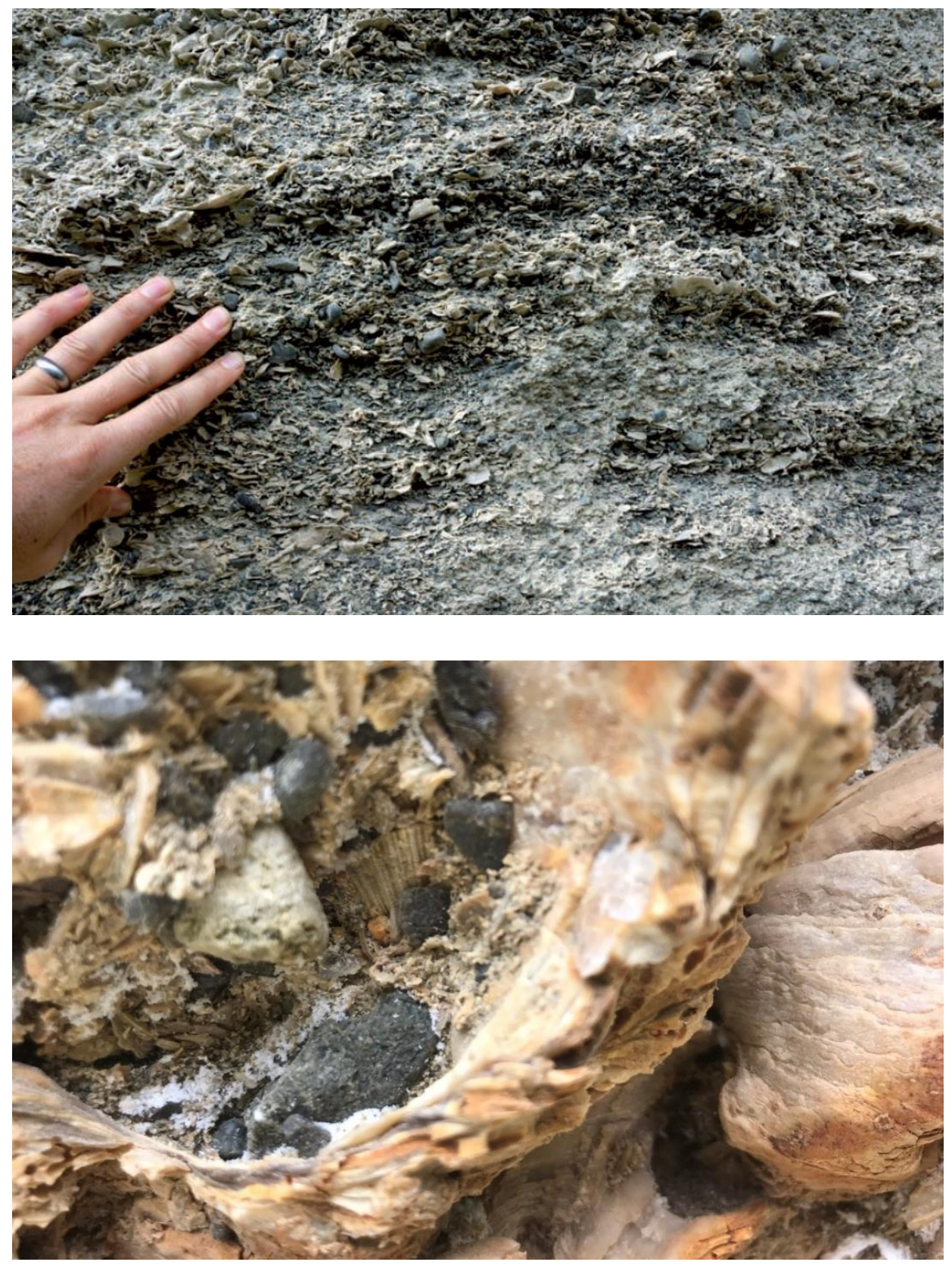


\section{CHAPTER SEVEN CONCLUSION}

\subsection{SUMMARY OF WORK}

This project set out to further our understanding of the paleoenvironment of the Hautawa Shellbed and to increase the resolution of the paleogeographic reconstructions for the base of the Nukumaruan Stage at 2.40 Ma. To achieve these aims high resolution measured sections that recorded changing macrofossil assemblage and its taphonomic characteristics were conducted at localities in the central Whanganui Basin. Assessment of foraminiferal assemblages from these sections constrained estimates of the paleowater depth. Reconstructions of the Taranaki and East Coast Basins from other sources were used to in conjunction with new information gained through this study to construct the paleogeography presented here.

\subsection{KEY FINDINGS}

The significant outcomes of this study as summarised as follows:

- The Hautawa Shellbed is preserved as both a condensed compound onlap-backlap shellbed at its type section, but elsewhere is observed as a lower onlap and an upper mid-cycle backlap shellbed separated by a barren terrigenoclastic shore-connected sediment wedge. The first structure is an asymmetric and the second is symmetric cycle of Kondo et al. (1998) and Saul et al. (1999).

- Combining the results of k-means cluster analysis of in situ documented macrofossil and taphonomic datasets enables the recognition of six biofacies which have been correlated into three distinct subunits.

- This is presented in the facies scheme presented (Figure 3.4.1, pg. 65): subunit A = a 'sediment-starved' bed, localised subunit $B=$ 'shell lag' bed, and subunit $C=$ 
a 'sediment-starved' bed of Hendy et al. (2006). Subunits A and B form as onlap style and subunit $\mathrm{C}$ as backlap.

- Recently discovered outcrops, published in J. Lee et al. (2011) as Hautawa Shellbed Member and plotted in QMAP for Hawke's Bay Region, are shown to be Nukumaruan in age based on foraminifera. They are likely to be correlatives to the Hautawa Shellbed deposited during either of the glacial transgressions in which Zygochlamys is noted in the central Whanganui Basin, but which sequence cycle and marine isotope stage still needs further work.

\subsection{SUGGESTIONS FOR FURTHER STUDY}

- Further work is needed on foraminifera contained within the Hautawa Shellbed in order to constrain whether there is an overlap between the foraminiferal zone of dominantly dextral Globorotalia crassaformis and Globorotalia crassula and the first arrival of Zygochlamys delicatula in the Whanganui Basin (R. Cooper \& Agterberg, 2004).

- The link between the central basin Hautawa Shellbed and the western lateral variant, the Kuranui Limestone, remains an issue for understanding the geologic history and paleoenvironment of the Whanganui Basin at this time. 


\section{REFERENCES}

Abbott, S. T. (1997). Mid-cycle condensed shellbeds from mid-Pleistocene cyclothems, New Zealand: implications for sequence architecture. Sedimentology, 44(5), 805824.

Adler, D., Murdoch, M. D., Suggests, M., WebGL, P., OBJ, S., \& OpenGL, S. (2018). Package 'rgl'. In: Von http://cran. at. r-project. org/: http://cran. r-project. org/web/packages/rgl/rgl. pdf abgerufen.

Andrews, P. B. (1982). Revised guide to recording field observations in sedimentary sequences: Department of Scientific \& Industrial Research.

Behrensmeyer, A. K., \& Kidwell, S. M. (1985). Taphonomy's contributions to paleobiology. Paleobiology, 11(1), 105-119.

Bertaud-Gandar, T. (2015). Stratigraphic investigations into the late Miocene-early Pliocene of the northern Aorangi Range, Wairarapa.

Beu, A. (1969). Index macrofossils and New Zealand Pliocene and lower Pleistocene time-stratigraphy. New Zealand journal of geology and geophysics, 12(4), 643658.

Beu, A. (2001). Local stages to be used for the Wanganui Series (Pliocene-Pleistocene), and their means of definition. New Zealand journal of geology and geophysics, 44(1), 113-125.

Beu, A., Browne, G., \& Grant-Taylor, T. (1981). New Chlamys delicatula localities in the central North Island and uplift of the Ruahine Range. New Zealand journal of geology and geophysics, 24(1), 127-132.

Beu, A., Grant-Taylor, T., \& Hornibrook, N. d. B. (1977). Nukumaruan records of the subantarctic scallop Chlamys delicatula and crab Jacquinotia edwardsii in central Hawke's Bay. New Zealand journal of geology and geophysics, 20(2), 217-248.

Beu, A., \& Maxwell, P. (1990). Cenozoic Mollusca of New Zealand: New Zealand Geological Survey Palaeontological Bulletin 58. New Zealand, 75-454.

Beu, A. G. (1995). Pliocene limestones and their scallops: lithostratigraphy, pectinid biostratigraphy, and paleogeography of eastern North Island late Neogene limestone: Institute of Geological \& Nuclear Sciences Limited.

Beu, A. G., Browne, G. H., \& Grant-Taylor, T. L. (1981). New Chlamys delicatula localities in the central North Island and uplift of the Ruahine Range. New Zealand journal of geology and geophysics, 24(1), 127-132.

Beu, A. G., \& Raine, J. (2009). Revised descriptions of New Zealand Cenozoic Mollusca from Beu and Maxwell (1990). GNS Science miscellaneous series, 27.

Bland, K. J., Kamp, P. J., \& Nelson, C. S. (2007). Systematic lithostratigraphy of the Neogene succession exposed in central parts of Hawke's Bay Basin, eastern North Island, New Zealand.

Bland, K. J., Kamp, P. J., \& Nelson, C. S. (2008). Late Miocene-Early Pleistocene paleogeography of the onshore central Hawke's Bay sector of the forearc basin, 
eastern North Island, New Zealand, and some implications for hydrocarbon prospectivity.

Borcard, D., Gillet, F., \& Legendre, P. (2011). Numerical ecology with R: Springer Science \& Business Media.

Browne, G. (2004a). Field Trip 6: The Miocene-Pliocene interior seaway of the central North Island: sedimentary patterns and tectonic styles in the Kuripapango Strait. Geological Society of New Zealand, 89-109.

Browne, G. (2004b). Late Neogene sedimentation adjacent to the tectonically evolving North Island axial ranges: Insights from Kuripapango, western Hawke's Bay. New Zealand journal of geology and geophysics, 47(4), 663-674.

Carter, R. (1972). Wanganui Strata of komako district, pohangina valley, ruahine range, manawatu. Journal of the Royal Society of New Zealand, 2(3), 293-324.

Carter, R., \& Naish, T. (1998). A review of Wanganui Basin, New Zealand: global reference section for shallow marine, Plio-Pleistocene $(2.5-0 \mathrm{Ma})$ cyclostratigraphy. Sedimentary Geology, 122(1-4), 37-52.

Catuneanu, O. (2002). Sequence stratigraphy of clastic systems: concepts, merits, and pitfalls. Journal of African Earth Sciences, 35(1), 1-43.

Cooper, G., \& Lee, D. (1993). Calloria, a replacement name for the recent brachiopod genus Waltonia from New Zealand. Journal of the Royal Society of New Zealand, 23(3), 257-270.

Cooper, R., \& Agterberg, F. (2004). The New Zealand geological timescale (Vol. 22): Institute of Geological \& Nuclear Sciences Limited.

Davey, F., \& Stern, T. (1990). Crystal Seismic observations across the convergent plate boundary, North Island, New Zealand. Tectonophysics, 173(1-4), 283-296.

Dunbar, G., \& Barrett, P. (2005). Estimating palaeobathymetry of wave-graded continental shelves from sediment texture. Sedimentology, 52(2), 253-269.

Feldmeyer, A., Jones, B., Firth, C., \& Knight, J. (1943). Geology of the PalmerstonWanganui Basin, West Side, North Island, New Zealand. The Superior Oil Co. New Zealand Ltd. Typescript report filed with IGNS, Lower Hutt, Wellington.

Fleming, C. (1944). Molluscan evidence of Pliocene climatic change in New Zealand.

Fleming, C. (1953). The geology of Wanganui subdivision, Waverley and Wanganui sheet districts (N137-138). New Zealand Geol. Surv. Bull., 52, 1-362.

Fraley, C., \& Raftery, A. E. (2006). MCLUST version 3: an R package for normal mixture modeling and model-based clustering. Retrieved from

Freeman, E. (2012). Presence-absence model evaluation. R package version 1.1. 9. In.

Hayward, B. (1999). Recent New Zealand shallow-water benthic foraminifera: taxonomy, ecologic distribution, biogeography, and use in paleoenvironmental assessment. Inst. Geol. Nucl. Sci. Monogr, 21, 264. 
Hayward, B. (2010). Recent New Zealand deep-water benthic foraminifera: Taxonomy, ecologic distribution, biogeography and use in paleoenvironmental assessment: GNS Science.

Hendy, A., Kamp, P., \& Vonk, A. (2006). Cool-water shell bed taphofacies from MiocenePliocene shelf sequences in New Zealand: Utility of taphofacies in sequence stratigraphic analysis. Geological Society, London, Special Publications, 255(1), 283-305.

Hollis, C., Crundwell, M., Beu, A., Morgans, H., Crampton, J., Raine, J., . . Boyes, A. (2010). Calibration of the New Zealand Cretaceous-Cenozoic Timescale to GTS2004.

Hornibrook, N. d. B. (1981). Globorotalia (planktic Foraminiferida) in the late Pliocene and early Pleistocene of New Zealand. New Zealand journal of geology and geophysics, 24(2), 263-292.

Jenkins, D. (1971). Stratigraphic position of the New Zealand Pliocene-Pleistocene boundary: Comment. New Zealand journal of geology and geophysics, 14(2), 418-420.

Journeaux, T., Kamp, P., \& Naish, T. (1996). Middle Pliocene cyclothems, Mangaweka region, Wanganui Basin, New Zealand: a lithostratigraphic framework. New Zealand journal of geology and geophysics, 39(1), 135-149.

Kamp, P. J., \& McIntyre, A. P. (1998). The stratigraphic architecture of late Pliocene (2.8$2.4 \mathrm{Ma}$ ) asymmetrical shelf sequences, western Wanganui Basin, New Zealand. Sedimentary Geology, 122(1-4), 53-67.

Kassambara, A., \& Mundt, F. (2017). Package 'factoextra,'. R topics documented, 75.

Kidwell, S. (1991). Condensed deposits in siliciclastic sequences: expected and observed features. Cycles and events in stratigraphy.

Kondo, Y., Abbott, S. T., Kitamura, A., Kamp, P. J., Naish, T. R., Kamataki, T., \& Saul, G. S. (1998). The relationship between shellbed type and sequence architecture: examples from Japan and New Zealand. Sedimentary Geology, 122(1-4), 109127.

Lê, S., Josse, J., \& Husson, F. (2008). FactoMineR: an R package for multivariate analysis. Journal of statistical software, 25(1), 1-18.

Lee, D. (1978). Aspects of the ecology and paleoecology of the brachiopod Notosaria nigricans (Sowerby). Journal of the Royal Society of New Zealand, 8(4), 395-417.

Lee, J., Bland, K., Townsend, D., \& Kamp, P. (2011). Geology of the Hawke's Bay area (Vol. 8): Institute of Geological and Nuclear Sciences.

Mclntyre, A. (2002). Geology of Mangapanian (late Pliocene) strata, Wanganui Basin: lithostratigraphy, paleontology and sequence stratigraphy. University of Waikato,

McIntyre, A., \& Kamp, P. (1998). Late Pliocene (2.8-2.4 Ma) cyclothemic shelf deposits, Parikino, Wanganui Basin, New Zealand: Lithostratigraphy and correlation of cycles. New Zealand journal of geology and geophysics, 41(1), 69-84. 
Mildenhall, D. (1978). Palynology of the Waipipian and Hautawan stages (Pliocene and Pleistocene), Wanganui, New Zealand (Note). New Zealand journal of geology and geophysics, 21(6), 775-777.

Milne, J. (1968). The geology and soils of the Apiti District. Victoria University of Wellington,

Milner, A. (2017). The Pliocene-Pleistocene Development, Uplift and Emergence History of the Manawatu Strait, New Zealand.

Mortimer, N., Campbell, H. J., Tulloch, A. J., King, P. R., Stagpoole, V. M., Wood, R. A., . . . Collot, J. (2017). Zealandia: Earth's hidden continent. GSA Today, 27(3), 27-35.

Naish, T. (2005). Preface: New Zealand's shallow-marine record of Pliocene-Pleistocene global sea-level and climate change. In: Taylor \& Francis.

Naish, T., Abbott, S., Alloway, B., Beu, A., Carter, R., Edwards, A., . . Saul, G. (1998). Astronomical calibration of a southern hemisphere Plio-Pleistocene reference section, Wanganui Basin, New Zealand. Quaternary Science Reviews, 17(8), 695710.

Naish, T., \& Kamp, P. (1995). Pliocene-Pleistocene marine cyclothems, Wanganui Basin, New Zealand: A lithostratigraphic framework. New Zealand journal of geology and geophysics, 38(2), 223-243.

Naish, T., \& Kamp, P. (1997a). Foraminiferal depth palaeoecology of Late Pliocene shelf sequences and systems tracts, Wanganui Basin, New Zealand. Sedimentary Geology, 110(3-4), 237-255.

Naish, T., \& Kamp, P. (1997b). Sequence stratigraphy of sixth-order (41 ky) PliocenePleistocene cyclothems, Wanganui basin, New Zealand: a case for the regressive systems tract. Geological Society of America Bulletin, 109(8), 978-999.

Naish, T., Kamp, P., Alloway, B., Pillans, B., Wilson, G., \& Westgate, J. (1995). Tephrostratigraphy and integrated chronology for Pliocene-Pleistocene marine cyclothemic strata, Wanganui Basin: implications for the Pliocene-Pleistocene boundary in New Zealand. Quaternary International, 34, 29-49.

Nelson, C., Hendy, I., Neil, H., Hendy, C., \& Weaver, P. (2000). Last glacial jetting of cold waters through the Subtropical Convergence zone in the Southwest Pacific off eastern New Zealand, and some geological implications. Palaeogeography, Palaeoclimatology, Palaeoecology, 156(1), 103-121.

Nicol, A. (2011). Landscape history of the Marlborough sounds, New Zealand. New Zealand journal of geology and geophysics, 54(2), 195-208.

Oksanen, J., Kindt, R., Legendre, P., O’Hara, B., Stevens, M. H. H., Oksanen, M. J., \& Suggests, M. (2007). The vegan package. Community ecology package, 10, 631637.

Orpin, A., Gammon, P., Naish, T., \& Carter, R. (1998). Modern and ancient Zygochlamys delicatula shellbeds in New Zealand, and their sequence stratigraphic implications. Sedimentary Geology, 122(1-4), 267-284. 
Patzkowsky, M. E., \& Holland, S. M. (2012). Stratigraphic paleobiology: understanding the distribution of fossil taxa in time and space: University of Chicago Press.

Pillans, B., Chappell, J., \& Naish, T. R. (1998). A review of the Milankovitch climatic beat: template for Plio-Pleistocene sea-level changes and sequence stratigraphy. Sedimentary Geology, 122(1-4), 5-21.

Raine, J. I., Beu, A. G., Boyes, A. F., Campbell, H., Cooper, R. A., Crampton, J. S., . . . Morgans, H. (2015). Revised calibration of the New Zealand Geological Timescale: NTGT2015/1: GNS Science Lower Hutt.

Rees, C. (2015). The geology of the lower Pohangina Valley, Manawatu, New Zealand: a thesis presented in partial fulfilment of the requirements for the degree of Master of Science in Earth Science at Massey University, Palmerston North, New Zealand. Massey University,

Rees, C., Palmer, J., \& Palmer, A. (2018a). Gilbert-style Pleistocene fan delta reveals tectonic development of North Island axial ranges, New Zealand. New Zealand journal of geology and geophysics, 61(1), 64-78.

Rees, C., Palmer, J., \& Palmer, A. (2018b). Plio-Pleistocene geology of the Lower Pohangina Valley, New Zealand. New Zealand journal of geology and geophysics, 61(1), 44-63.

Saul, G., Naish, T., Abbott, S., \& Carter, R. (1999). Sedimentary cyclicity in the marine Pliocene-Pleistocene of the Wanganui basin (New Zealand): Sequence stratigraphic motifs characteristic of the past $2.5 \mathrm{my}$. Geological Society of America Bulletin, 111(4), 524-537.

Sefton, J. (2015). An assessment of the influence of orbital forcing on Late Pliocene global sea-level using a shallow-marine sedimentary record from the Wanganui Basin, New Zealand.

Strogen, D. (2011). Updated paleogeographic maps for the Taranaki Basin and surrounds. Lower Hutt, New Zealand: GNS Science.

Suggate, R. (1990). Late pliocene and quaternary glaciations of New Zealand. Quaternary Science Reviews, 9(2-3), 175-197.

Team, R. C. (2002). The R stats package. R Foundation for Statistical Computing, Vienna, Austria: Available from: http://www.R-project.org

Team, R. C. (2017). R: a language and environment for statistical computing. Vienna, Austria: R Foundation for Statistical Computing; 2017. In.

Townsend, D., Kamp, P., \& Vonk, A. (2008). Geology of the Taranaki area: Institute of Geological \& Nuclear Sciences.

Trewick, S., \& Bland, K. (2012). Fire and slice: palaeogeography for biogeography at New Zealand's North Island/South Island juncture. Journal of the Royal Society of New Zealand, 42(3), 153-183.

Wickham, H. (2016a). ggplot2: elegant graphics for data analysis: Springer.

Wickham, H. (2016b). tidyr: Easily Tidy Data with spread () and gather () Functions. Version 0.6. 0 . 


\section{REFERENCES}

Wickham, H., \& Chang, W. (2016). devtools: Tools to Make Developing R Packages Easier. R package version 1.7. 0. In.

Wickham, H., \& Francois, R. (2015). dplyr: A grammar of data manipulation. $R$ package version $0.4,3$. 
APPENDIX

\section{APPENDIX}

\section{A.1 GRAIN SIZE}

Below is a table containing the grain size data collected during processing of sediment samples for foraminiferal content. The sieved $<63$ fraction as a percentage of the sum was used as the proxy of 'percent mud' contained in the sample. \% loss measures the change in weight between the initial sample weight measured and the final sum of dried weights.

Grain size fractions (microns, $\mu m$ )

\begin{tabular}{|c|c|ccccc|c|c|}
\hline Sample \# & weight (g) & $>\mathbf{5 0 0}$ & $\mathbf{1 5 0 - 5 0 0}$ & $\mathbf{1 2 5}-\mathbf{1 5 0}$ & $\mathbf{6 3 - 1 2 5}$ & $<63$ & sum (g) & \% loss \\
\hline $\mathbf{0 0 1 / 1}$ & 52.05 & 6.76 & 3.62 & 1.26 & 3.56 & 30.45 & 45.65 & $12 \%$ \\
$\mathbf{0 0 2 / 1}$ & 50.7 & 2.72 & 4.47 & 5.59 & 12.3 & 17.04 & 42.12 & $17 \%$ \\
$\mathbf{0 0 3 / 1}$ & 50.33 & 2.82 & 7.51 & 4.93 & 8.63 & 18.3 & 42.19 & $16 \%$ \\
$\mathbf{0 0 4 / 1}$ & 50.62 & 1.04 & 1.27 & 0.88 & 6.57 & 32.34 & 42.10 & $17 \%$ \\
$\mathbf{0 0 5 / 1}$ & 51.48 & 0.87 & 2.06 & 0.86 & 7.13 & 32.26 & 43.18 & $16 \%$ \\
$\mathbf{0 0 6 / 1}$ & 55.79 & 1.14 & 2.20 & 1.43 & 7.40 & 34.05 & 46.22 & $17 \%$ \\
$\mathbf{0 0 7 / 1}$ & 51.64 & 0.32 & 2.19 & 0.95 & 3.27 & 35.22 & 41.95 & $19 \%$ \\
$\mathbf{0 0 8 / 1}$ & 54.40 & 1.53 & 5.57 & 1.39 & 8.74 & 30.87 & 48.10 & $12 \%$ \\
$\mathbf{0 0 9 / 1}$ & 53.55 & 1.21 & 4.73 & 4.18 & 14.65 & 22.92 & 47.69 & $11 \%$ \\
$\mathbf{0 1 0 / 1}$ & 51.64 & 1.31 & 16.21 & 4.71 & 6.94 & 19.58 & 48.75 & $6 \%$ \\
$\mathbf{0 1 1 / 1}$ & 51.22 & 1.58 & 8.52 & 2.25 & 7.48 & 22.66 & 42.49 & $17 \%$ \\
$\mathbf{0 1 2 / 1}$ & 50.75 & 1.31 & 16.21 & 4.71 & 9.94 & 15.62 & 47.79 & $6 \%$ \\
$\mathbf{0 1 3 / 1}$ & 52.61 & 1.08 & 8.32 & 3.80 & 8.73 & 15.31 & 37.24 & $29 \%$ \\
$\mathbf{0 1 4 / 1}$ & 51.57 & 0.62 & 3.04 & 5.01 & 17.29 & 16.94 & 42.90 & $17 \%$ \\
$\mathbf{0 1 5 / 1}$ & 53.58 & 0.96 & 5.36 & 6.96 & 17.27 & 15.54 & 46.09 & $14 \%$ \\
\hline
\end{tabular}




\section{A.2 FORAMINIFERAL SAMPLE ASSEMBLAGES}

The table below contains the foraminiferal assemblage census data recorded from each sediment sample.

\begin{tabular}{|c|c|c|c|c|c|c|c|c|c|c|c|c|c|c|c|c|c|}
\hline \multicolumn{16}{|c|}{ ROTALIIDA } & \multirow{2}{*}{\begin{tabular}{|l} 
Order \\
Genera
\end{tabular}} & \\
\hline 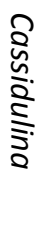 & $\mid \begin{array}{l}\frac{0}{2} \\
\frac{0}{2} \\
\frac{2}{3} \\
2\end{array}$ & 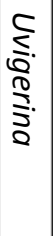 & 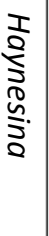 & 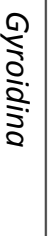 & 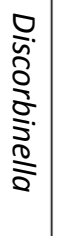 & & $\frac{\frac{m}{2}}{\frac{m}{2}}$ & & & $\frac{2}{\frac{2}{2}}$ & & 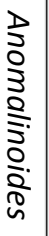 & 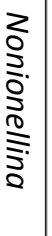 & & 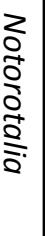 & & \\
\hline$\frac{n}{?}$ & $\cong$ & $\dddot{n}$ & 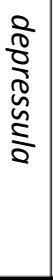 & $\begin{array}{l}\stackrel{u}{o} \\
\frac{2}{2} \\
\stackrel{s}{s}\end{array}$ & $\frac{y}{0}$ & 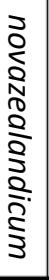 & 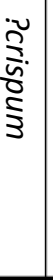 & $\frac{n}{y}$ & 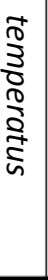 & 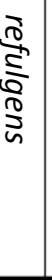 & 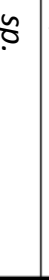 & $\frac{n}{6}$ & 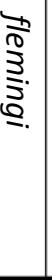 & 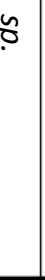 & $\tilde{c}$ & Species & \\
\hline 0 & $\mapsto$ & $N$ & 0 & $\mapsto$ & 0 & 0 & 0 & 0 & $v$ & $\infty$ & $\sigma$ & 0 & $D$ & 0 & ज̆ & $001 / 1$ & Otiwhiti \\
\hline 0 & 0 & 0 & 0 & 0 & 0 & 0 & 0 & के & 0 & $\circ$ & $\omega$ & 0 & N & 0 & 㝒 & $002 / 1$ & Otiwhiti \\
\hline 0 & 0 & $v$ & 0 & $\omega$ & 0 & 0 & 0 & 0 & $\triangle$ & $\sim$ & 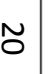 & 0 & $\omega$ & 0 & $\stackrel{\bullet}{\bullet}$ & $003 / 1$ & West Rd \\
\hline 0 & 0 & 0 & $\triangle$ & 0 & 0 & $\omega$ & 0 & $\vec{\perp}$ & 0 & 0 & 0 & 0 & जू & 0 & 홍 & $004 / 1$ & West Rd \\
\hline$\omega$ & $\sim$ & $\tilde{\infty}$ & $\sigma$ & 0 & $\omega$ & 0 & 0 & $\vec{\sim}$ & $\sim$ & $\circ$ & $v$ & $\sim$ & 它 & $\sim$ & $\underset{\omega}{M}$ & $005 / 1$ & Otiwhiti \\
\hline$\tilde{O}$ & 0 & $\vec{\phi}$ & 官 & $\bullet$ & $\tilde{o}$ & 0 & 0 & 它 & $\vdash$ & $\stackrel{\sim}{\sim}$ & $\infty$ & $\sim$ & $\sigma$ & 0 & $\begin{array}{l}\infty \\
\infty\end{array}$ & $006 / 1$ & Otiwhiti \\
\hline$\sim$ & 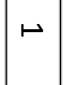 & $\mapsto$ & 0 & 0 & 0 & 0 & 0 & 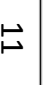 & 0 & 0 & $\circ$ & 0 & $N$ & $\Delta$ & 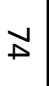 & & West Rd \\
\hline$\tilde{D}$ & $\vdash$ & $N$ & $\circ$ & $\sim$ & $\infty$ & 0 & 0 & ज̃ & ๖ & 0 & $\circ$ & $\circ$ & ம & 0 & 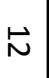 & $008 / 1$ & Ridge Rd \\
\hline 它 & 0 & $a$ & $\circ$ & 它 & 0 & 0 & ० & 它 & $\tilde{v}$ & $\circ$ & 0 & 6 & $\infty$ & $\sim$ & 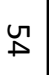 & $010 / 1$ & Colenso \\
\hline$\stackrel{\sim}{\sim}$ & 0 & $v$ & 0 & $\omega$ & 0 & 0 & $\circ$ & 6 & $\sim$ & $\circ$ & 0 & 0 & $\sim$ & $\Delta$ & $\vec{N}$ & $012 / 1$ & Colenso \\
\hline$\stackrel{\infty}{\infty}$ & $\circ$ & $a$ & 0 & $\triangle$ & 0 & 0 & $\Delta$ & 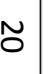 & $\sim$ & $\circ$ & 0 & 0 & a & 0 & D & $013 / 1$ & Colenso \\
\hline$\mapsto$ & $\circ$ & $\omega$ & 。 & $v$ & $\tilde{\omega}$ & $\circ$ & ० & $\sim$ & 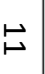 & 0 & 0 & o & 0 & 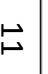 & $\stackrel{\sim}{\bullet}$ & $014 / 1$ & Ridge Rd \\
\hline N & 0 & 0 & ๖ & 0 & 0 & 0 & 0 & $\tilde{\omega}$ & $\sigma$ & 0 & 0 & $v$ & $\omega$ & 0 & $\stackrel{\leftrightarrow}{N}$ & 015/1 & Ridge Rd \\
\hline
\end{tabular}


Note that samples: 007, 009, and 011 are considered barren due to low specimen density. Only 007 is included here as a total of 166 specimen were picked.

\begin{tabular}{|c|c|c|c|c|c|c|c|c|c|c|c|c|c|c|c|c|c|c|c|c|c|c|c|c|c|}
\hline \multirow[t]{3}{*}{-1 } & \multicolumn{4}{|c|}{ OTHER } & \multicolumn{10}{|c|}{ GLOBIGERINIDA } & \multicolumn{6}{|c|}{ LAGENIDA } & $\begin{array}{l}\frac{3}{\bar{O}} \\
\frac{\bar{O}}{\bar{D}} \\
\frac{\bar{D}}{D}\end{array}$ & 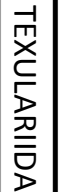 & \multicolumn{3}{|c|}{ 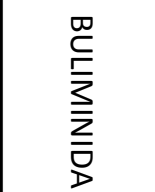 } \\
\hline & $\begin{array}{l}z \\
0 \\
0 \\
\frac{1}{0} \\
\frac{1}{0} \\
\frac{3}{3} \\
w\end{array}$ & 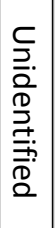 & 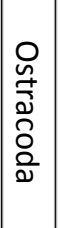 & 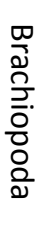 & 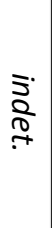 & \begin{tabular}{l} 
우 \\
$\vdots$ \\
ș \\
\multirow{2}{2}{}
\end{tabular} & & & $\begin{array}{l}\frac{a}{2} \\
\frac{0}{0} \\
\frac{0}{0} \\
\frac{0}{0} \\
\frac{0}{2}\end{array}$ & & & & 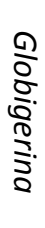 & & 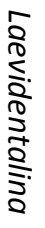 & 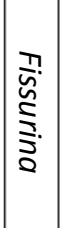 & 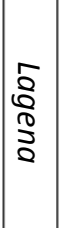 & 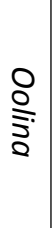 & T) & $\overbrace{n}^{n}$ & 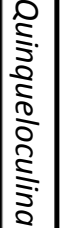 & 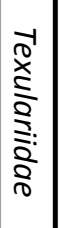 & 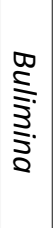 & 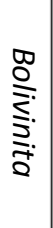 & $\begin{array}{l}\text { Do } \\
\text { o } \\
\text { s. } \\
\text { s. }\end{array}$ \\
\hline & & & & & & $\underline{0}$ & $\begin{array}{l}\frac{5}{0} \\
\frac{0}{2} \\
\frac{d}{2}\end{array}$ & 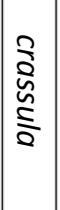 & 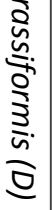 & 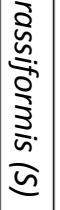 & $\frac{n}{c}$ & 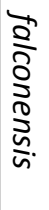 & 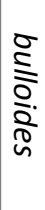 & y & $\check{0}$ & $\frac{n}{0}$ & $\tilde{l}$ & $\frac{n}{0}$ & $\frac{n}{0}$ & $\frac{4}{?}$ & $\frac{y}{0}$ & $\frac{y}{0}$ & $\frac{n}{0}$ & $\frac{y}{0}$ & $\frac{y}{x}$ \\
\hline 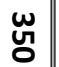 & $v$ & 8 & 0 & ڤ̆ & 0 & 0 & 0 & 0 & 0 & 0 & 0 & 0 & 0 & $v$ & 0 & a & $\Delta$ & மे & $\sim$ & 0 & $v \mid$ & $\mapsto$ & $\infty$ & 0 & $\infty$ \\
\hline$\tilde{E}$ & 6 & $\stackrel{\omega}{\omega}$ & 0 & 0 & 0 & o & 0 & 0 & 0 & 0 & 0 & o & $\vec{n}$ & $\mapsto$ & 0 & 0 & $\mapsto$ & 0 & $\vdash$ & 0 & $\omega$ & 0 & u & 0 & 割 \\
\hline$\stackrel{8}{0}$ & v & $\tilde{N}$ & 0 & 0 & 0 & 0 & 0 & 0 & o & 0 & 0 & 0 & 0 & 0 & ○ & $\vdash$ & $\sim$ & o & $\sim$ & N & 0 & $\overrightarrow{6}$ & $\ddot{o}$ & ० & $\tilde{\omega}$ \\
\hline$\stackrel{\omega}{\Delta}$ & v & $\mapsto$ & $a$ & ○ & 0 & 0 & 0 & 0 & ○ & 0 & 0 & 0 & 0 & N & $\sim$ & $\bullet$ & $\bullet$ & $\Delta$ & 0 & 0 & $\sim$ & $\approx$ & $\omega$ & ० & N \\
\hline 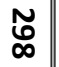 & $\bullet$ & $\tilde{\Delta}$ & 0 & o & 0 & 0 & 0 & 0 & 0 & $\vdash$ & ○ & $\vec{b}$ & $\vec{\bullet}$ & $\tilde{6}$ & 0 & $\vdash$ & 항 & $\bullet$ & $\mapsto$ & 0 & 0 & 0 & $N$ & $\vdash$ & $\tilde{o}$ \\
\hline$\vec{v}$ & 6 & $\widetilde{\infty}$ & 0 & ○ & 0 & 0 & 0 & 0 & o & 0 & 0 & 0 & 0 & ○ & 0 & 0 & $\mapsto$ & 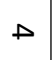 & $\mapsto$ & $\mapsto$ & 0 & $\tilde{\infty}$ & $\sim$ & $\sim$ & U \\
\hline ด̆ & u & $\tilde{\sigma}$ & $a$ & 0 & 0 & 0 & 0 & 0 & $\sim$ & 0 & 0 & 0 & 0 & 0 & 0 & 0 & 0 & 0 & $\vdash$ & 0 & 0 & 0 & 0 & $\triangleright$ & $\stackrel{\vec{N}}{\sim}$ \\
\hline 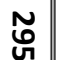 & மे & $\vec{\omega}$ & 0 & 0 & 0 & 0 & 0 & 0 & 0 & $\vec{\omega}$ & 0 & 0 & 0 & \pm & 0 & $\mapsto$ & $\sim$ & 0 & 0 & 0 & $\sim$ & $\vec{\omega}$ & $\vec{\omega}$ & 0 & u \\
\hline$\underset{\omega}{\omega}$ & $\omega$ & $\tilde{\sigma}$ & $a$ & 0 & เ & $\infty$ & $\sim$ & 0 & 0 & $\bullet$ & 0 & 0 & $\vec{v}$ & ${\underset{\omega}{\omega}}^{\omega}$ & $\sim$ & $\sim$ & $D$ & 0 & 0 & 0 & 0 & ம & $\mapsto$ & 0 & $\bullet$ \\
\hline$\underset{g}{\omega}$ & v & $\underset{\bullet}{\omega}$ & $\stackrel{\vec{N}}{ }$ & 0 & $v$ & $\bullet$ & $\omega$ & 0 & 0 & 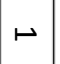 & $\omega$ & 0 & 0 & 0 & 0 & $\omega$ & 0 & 0 & 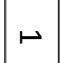 & 0 & 0 & $\underset{\omega}{\omega}$ & a & $\sim$ & $\infty$ \\
\hline $\mathrm{N}$ & 它 & N & b & 0 & $\stackrel{\sim}{\sim}$ & $\sim$ & 0 & 0 & 0 & 0 & 0 & 0 & 0 & $\dot{v}$ & $\omega$ & 0 & u & 0 & 0 & 0 & $\stackrel{\vec{N}}{ }$ & 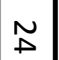 & u & 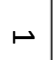 & $\stackrel{\vec{N}}{\mathrm{~N}}$ \\
\hline$\underset{\tilde{v}}{\boldsymbol{\omega}}$ & 0 & 6 & $\mapsto$ & 0 & 0 & 0 & 0 & 0 & 0 & 0 & 0 & 0 & 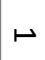 & $\bullet$ & 0 & $\omega$ & $\Delta$ & $\Delta$ & 0 & 0 & 0 & $\approx$ & $\mapsto$ & 0 & $\vec{v}$ \\
\hline$\underset{\tilde{\sigma}}{\mathbf{w}}$ & $\infty$ & $\tilde{N}$ & $v$ & 0 & 0 & 0 & 0 & 0 & 0 & 0 & 0 & 0 & 0 & 0 & 0 & $\vdash$ & $\mapsto$ & 0 & $\sim$ & 0 & 0 & $\mapsto$ & 0 & $\bullet$ & $\underset{\sim}{w}$ \\
\hline
\end{tabular}




\section{A.3 MACROFAUNA DATA FRAMES}

\section{A.3.1 Faunal Assemblage}

In the table below is the macrofaunal in situ census count dataset. The data is compiled as 'presence-absence' such that for any given genera $1=$ present and $0=a b s e n t$ in the sample frame. The cluster which each sample is placed by the data analysis is also included.

\begin{tabular}{|c|c|c|c|c|c|c|c|c|c|c|c|c|c|c|c|}
\hline \multicolumn{16}{|c|}{ Genera } \\
\hline & 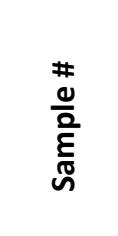 & 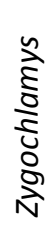 & $\begin{array}{l}0 \\
\frac{0}{0} \\
0\end{array}$ & 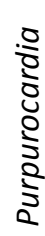 & 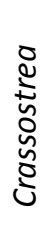 & 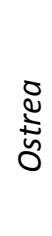 & 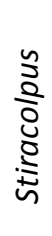 & 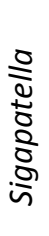 & $\begin{array}{l}\frac{0}{3} \\
\frac{0}{0} \\
\frac{2}{2} \\
0\end{array}$ & 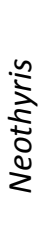 & 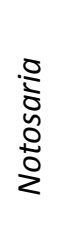 & $\frac{0}{0}$ & $\begin{array}{l}0 \\
\text { Dे } \\
\text { Dे } \\
\text { Dे }\end{array}$ & $\begin{array}{l}\frac{\tilde{u}}{\tilde{g}} \\
\frac{5}{\Delta} \\
\infty\end{array}$ & 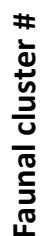 \\
\hline \multirow{8}{*}{ 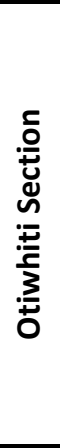 } & 5_1 & 1 & 0 & 1 & 1 & 1 & 1 & 0 & 0 & 1 & 0 & 0 & 0 & 0 & 2 \\
\hline & $5 \_2$ & 1 & 0 & 0 & 0 & 1 & 0 & 0 & 0 & 1 & 0 & 0 & 0 & 0 & 2 \\
\hline & 5_3 & 1 & 0 & 1 & 0 & 1 & 0 & 0 & 0 & 1 & 0 & 0 & 0 & 0 & 1 \\
\hline & 5B_1 & 1 & 0 & 1 & 0 & 1 & 0 & 0 & 1 & 1 & 1 & 1 & 1 & 0 & 4 \\
\hline & 5B_2 & 0 & 0 & 1 & 0 & 1 & 0 & 0 & 1 & 1 & 1 & 1 & 1 & 0 & 4 \\
\hline & 5B_3 & 1 & 0 & 0 & 0 & 1 & 1 & 0 & 1 & 1 & 1 & 0 & 1 & 0 & 1 \\
\hline & 5B_4 & 0 & 0 & 0 & 0 & 1 & 1 & 0 & 0 & 1 & 1 & 1 & 1 & 0 & 2 \\
\hline & 5B_5 & 0 & 0 & 0 & 0 & 1 & 1 & 0 & 1 & 1 & 1 & 0 & 1 & 0 & 4 \\
\hline \multirow{6}{*}{ 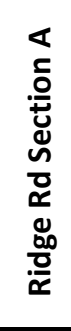 } & $14 \_1$ & 1 & 1 & 1 & 1 & 1 & 0 & 0 & 0 & 0 & 0 & 0 & 0 & 1 & 4 \\
\hline & $14 \_2$ & 1 & 0 & 1 & 0 & 1 & 1 & 0 & 0 & 1 & 0 & 0 & 0 & 0 & 4 \\
\hline & $14 \_3$ & 0 & 1 & 1 & 0 & 1 & 0 & 0 & 0 & 1 & 1 & 0 & 1 & 0 & 2 \\
\hline & $14 \_4$ & 1 & 1 & 1 & 0 & 1 & 1 & 1 & 1 & 1 & 0 & 0 & 1 & 0 & 4 \\
\hline & $14 \_5$ & 0 & 1 & 1 & 0 & 1 & 1 & 1 & 1 & 1 & 1 & 0 & 1 & 0 & 1 \\
\hline & $14 \_6$ & 1 & 0 & 0 & 0 & 1 & 0 & 1 & 1 & 1 & 0 & 0 & 1 & 0 & 1 \\
\hline \multirow{8}{*}{ 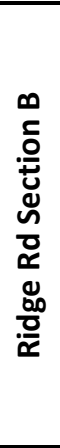 } & 14B_3 & 1 & 1 & 1 & 1 & 1 & 1 & 0 & 0 & 1 & 0 & 0 & 1 & 0 & 2 \\
\hline & 14B_4 & 1 & 1 & 1 & 0 & 1 & 1 & 0 & 0 & 1 & 0 & 0 & 1 & 0 & 1 \\
\hline & 14B_5 & 1 & 1 & 1 & 0 & 1 & 1 & 0 & 0 & 1 & 0 & 0 & 1 & 0 & 3 \\
\hline & 14B_6 & 1 & 0 & 1 & 0 & 1 & 0 & 0 & 1 & 1 & 0 & 0 & 0 & 0 & 1 \\
\hline & 14B_7 & 0 & 1 & 1 & 0 & 1 & 0 & 0 & 1 & 1 & 0 & 0 & 1 & 0 & 2 \\
\hline & 14B_8 & 0 & 0 & 1 & 0 & 1 & 1 & 1 & 0 & 1 & 1 & 0 & 1 & 0 & 2 \\
\hline & 14B_9 & 1 & 0 & 1 & 0 & 1 & 1 & 0 & 1 & 1 & 1 & 0 & 0 & 0 & 2 \\
\hline & 14B_10 & 1 & 0 & 1 & 0 & 1 & 0 & 0 & 1 & 0 & 1 & 0 & 0 & 0 & 4 \\
\hline \multirow{5}{*}{ 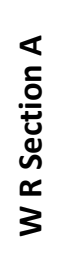 } & 15B_1 & 1 & 0 & 1 & 1 & 1 & 0 & 0 & 0 & 0 & 0 & 0 & 0 & 1 & 3 \\
\hline & 15B_2 & 1 & 0 & 1 & 1 & 1 & 0 & 0 & 0 & 0 & 0 & 0 & 0 & 0 & 3 \\
\hline & 15B_3 & 1 & 1 & 1 & 0 & 1 & 1 & 0 & 0 & 1 & 0 & 0 & 0 & 1 & 3 \\
\hline & 15B_4 & 1 & 0 & 1 & 0 & 1 & 1 & 0 & 0 & 1 & 0 & 0 & 0 & 1 & 2 \\
\hline & 15B_5 & 1 & 1 & 0 & 0 & 1 & 1 & 0 & 0 & 1 & 0 & 0 & 1 & 0 & 3 \\
\hline
\end{tabular}




\begin{tabular}{|c|c|c|c|c|c|c|c|c|c|c|c|c|c|c|c|}
\hline & 15B_6 & 0 & 0 & 0 & 0 & 1 & 0 & 1 & 0 & 1 & 0 & 0 & 1 & 0 & 3 \\
\hline & 15B_7 & 0 & 0 & 0 & 0 & 0 & 0 & 0 & 0 & 1 & 1 & 0 & 1 & 0 & 1 \\
\hline & 15B_9 & 1 & 0 & 0 & 0 & 0 & 0 & 0 & 0 & 1 & 1 & 0 & 1 & 0 & 3 \\
\hline & 15B_10 & 0 & 0 & 0 & 0 & 1 & 0 & 0 & 1 & 1 & 1 & 0 & 1 & 0 & 4 \\
\hline & 15B_11 & 0 & 0 & 0 & 0 & 0 & 1 & 0 & 0 & 1 & 0 & 0 & 1 & 0 & 4 \\
\hline & 15B_12 & 0 & 0 & 1 & 0 & 1 & 0 & 0 & 0 & 1 & 1 & 0 & 1 & 0 & 3 \\
\hline \multirow{18}{*}{ 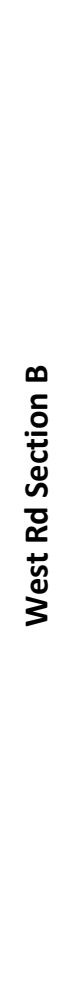 } & 15C_1 & 1 & 1 & 1 & 0 & 0 & 0 & 0 & 0 & 0 & 0 & 1 & 0 & 1 & 1 \\
\hline & 15C_2 & 1 & 1 & 1 & 0 & 0 & 1 & 0 & 0 & 0 & 0 & 0 & 0 & 1 & 1 \\
\hline & 15C_3 & 1 & 0 & 1 & 0 & 1 & 0 & 0 & 0 & 1 & 0 & 0 & 0 & 1 & 2 \\
\hline & 15C_4 & 0 & 1 & 0 & 0 & 1 & 1 & 0 & 1 & 0 & 0 & 0 & 0 & 0 & 2 \\
\hline & 15C_5 & 0 & 1 & 1 & 0 & 1 & 1 & 0 & 1 & 1 & 0 & 0 & 1 & 0 & 4 \\
\hline & 15C_6 & 0 & 1 & 1 & 0 & 0 & 0 & 0 & 0 & 1 & 0 & 0 & 1 & 0 & 4 \\
\hline & 15C_7 & 0 & 0 & 1 & 0 & 0 & 0 & 0 & 0 & 1 & 1 & 0 & 1 & 0 & 4 \\
\hline & 15C_8 & 0 & 0 & 0 & 0 & 0 & 0 & 0 & 1 & 1 & 0 & 1 & 1 & 1 & 3 \\
\hline & 15C_9 & 0 & 0 & 0 & 0 & 1 & 0 & 0 & 0 & 1 & 1 & 0 & 0 & 0 & 3 \\
\hline & 15C_10 & 0 & 0 & 0 & 0 & 1 & 0 & 0 & 0 & 1 & 0 & 0 & 1 & 0 & 1 \\
\hline & 15C_11 & 0 & 0 & 0 & 0 & 0 & 1 & 0 & 0 & 1 & 0 & 1 & 1 & 0 & 2 \\
\hline & 15C_12 & 0 & 0 & 0 & 0 & 1 & 1 & 0 & 0 & 1 & 1 & 0 & 0 & 0 & 2 \\
\hline & 15C_13 & 1 & 0 & 0 & 0 & 0 & 0 & 0 & 0 & 1 & 0 & 0 & 1 & 0 & 2 \\
\hline & 15C_14 & 0 & 1 & 1 & 0 & 1 & 1 & 0 & 0 & 1 & 1 & 0 & 1 & 0 & 1 \\
\hline & 15C_15 & 0 & 0 & 1 & 0 & 1 & 0 & 0 & 0 & 0 & 0 & 0 & 1 & 0 & 1 \\
\hline & 15C_16 & 0 & 0 & 0 & 0 & 1 & 1 & 0 & 0 & 1 & 0 & 0 & 1 & 0 & 1 \\
\hline & 15C_17 & 0 & 0 & 0 & 0 & 1 & 0 & 0 & 0 & 1 & 1 & 0 & 0 & 0 & 1 \\
\hline & 15C_18 & 1 & 0 & 0 & 0 & 1 & 0 & 0 & 0 & 1 & 1 & 0 & 1 & 0 & 1 \\
\hline
\end{tabular}




\section{A.3.2 Taphonomy}

The table below contains the in situ raw taphonomic data which was collected.

The taphonomic cluster into which each sample is placed by the data analysis is included.

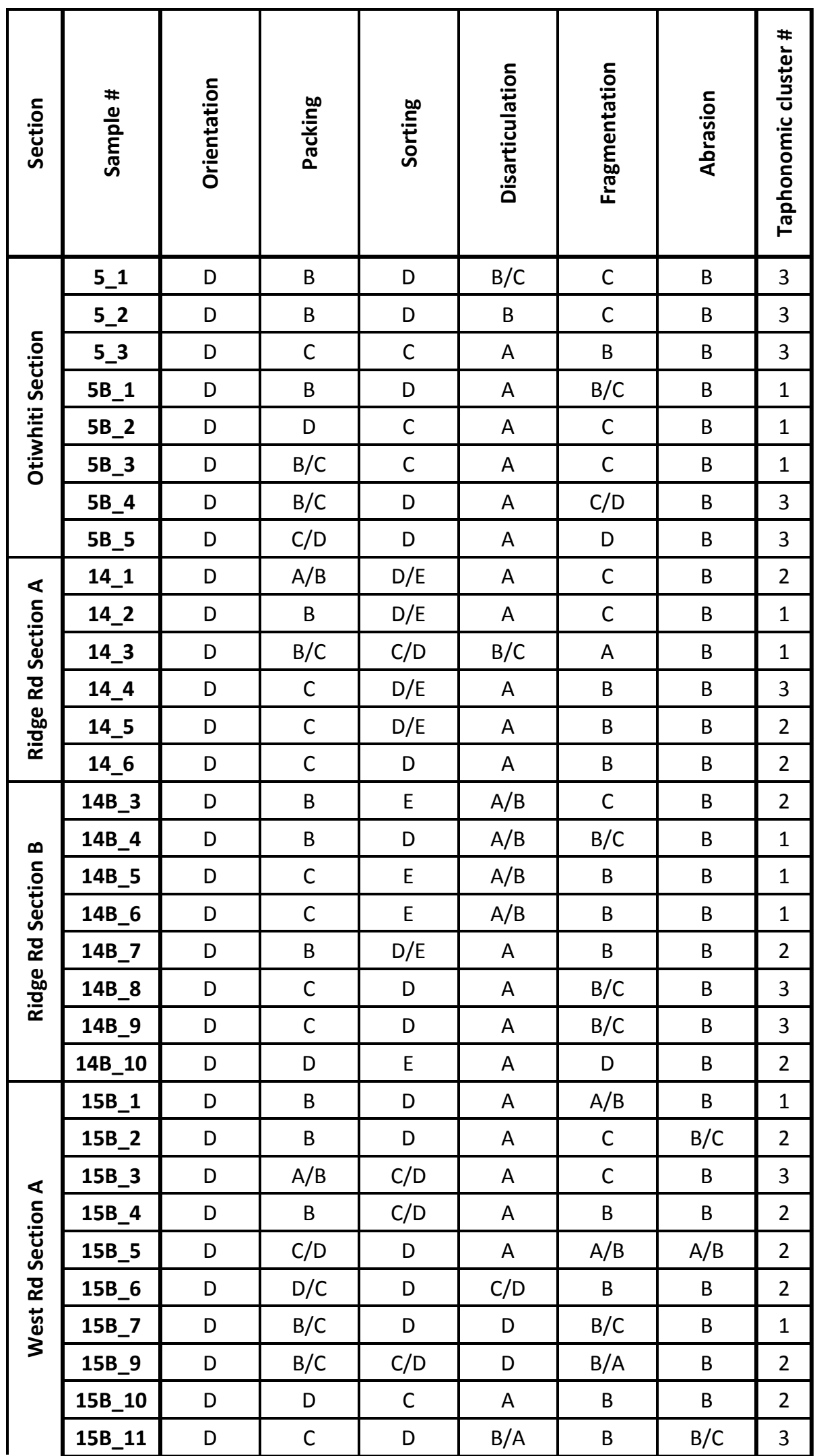




\begin{tabular}{|c|c|c|c|c|c|c|c|c|}
\hline & 15B_12 & $D / C$ & $C$ & $\mathrm{D}$ & $A$ & $B$ & $B$ & 2 \\
\hline \multirow{18}{*}{ 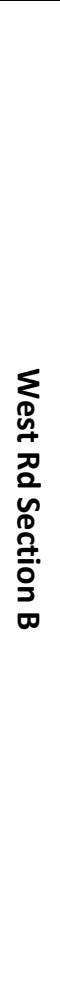 } & 15C_1 & D & B & D & A & B & B & 1 \\
\hline & $15 C_{-} 2$ & $\mathrm{D}$ & $A / B$ & $\mathrm{D}$ & $A$ & B & B & 2 \\
\hline & $15 C_{-} 3$ & $D$ & $B$ & $D$ & A & B & B & 1 \\
\hline & $15 C_{-} 4$ & $D / E$ & $B / C$ & $C / D$ & $A$ & $A / B$ & B & 2 \\
\hline & $15 C_{-} 5$ & $\mathrm{D}$ & $B$ & $D$ & $A$ & $A / B$ & $B$ & 3 \\
\hline & $15 C \_6$ & $\mathrm{D}$ & $A / B$ & $D$ & A & $\mathrm{B} / \mathrm{C}$ & $B$ & 2 \\
\hline & $15 C_{-} 7$ & $\mathrm{D}$ & $B$ & $D$ & $A$ & $B$ & B & 2 \\
\hline & $15 C \_8$ & $\mathrm{D}$ & $B$ & $C / D$ & $A$ & $A / B$ & $B$ & 2 \\
\hline & 15C_9 & $\bar{D}$ & $B$ & $\mathrm{D}$ & $A$ & $\mathrm{~B} / \mathrm{C}$ & $B$ & 3 \\
\hline & 15C_10 & $D$ & $B$ & $\mathrm{D}$ & $B$ & $\mathrm{~B} / \mathrm{C}$ & $B$ & 2 \\
\hline & 15C_11 & $\mathrm{D}$ & $B / C$ & $D$ & $A$ & $B / C$ & $B$ & 2 \\
\hline & 15C_12 & $\mathrm{D}$ & $C / D$ & $C$ & $A$ & $B$ & $B$ & 2 \\
\hline & 15C_13 & $\mathrm{D}$ & $C$ & $D$ & A & $\mathrm{B} / \mathrm{C}$ & $B$ & 1 \\
\hline & 15C_14 & $\mathrm{D}$ & $B$ & $D$ & $A$ & $A / B$ & B & 2 \\
\hline & 15C_15 & $\mathrm{D}$ & $B$ & $C / D$ & $A$ & $A / B$ & $B$ & 3 \\
\hline & 15C_16 & $\mathrm{D}$ & $B / C$ & $D$ & $A / B$ & $A / B$ & B & 3 \\
\hline & 15C_17 & $\mathrm{D}$ & $\mathrm{B} / \mathrm{C}$ & $D$ & $B$ & $B$ & $B$ & 2 \\
\hline & $15 C \_18$ & D & $C$ & $\mathrm{D}$ & $A / B$ & C & B & 2 \\
\hline
\end{tabular}




\section{A.4 R CODE: MACROFAUNA}

A.4.1 Code used in $\mathrm{R}$ to analyse macrofaunal assemblages
This code is used to produce, in unedited form, the following figures:

- $\quad$ Figures 3.2.1-3.2.6

- $\quad$ Figures 3.3.1-3.3.4

- $\quad$ Figures A.4.1-A.4.4

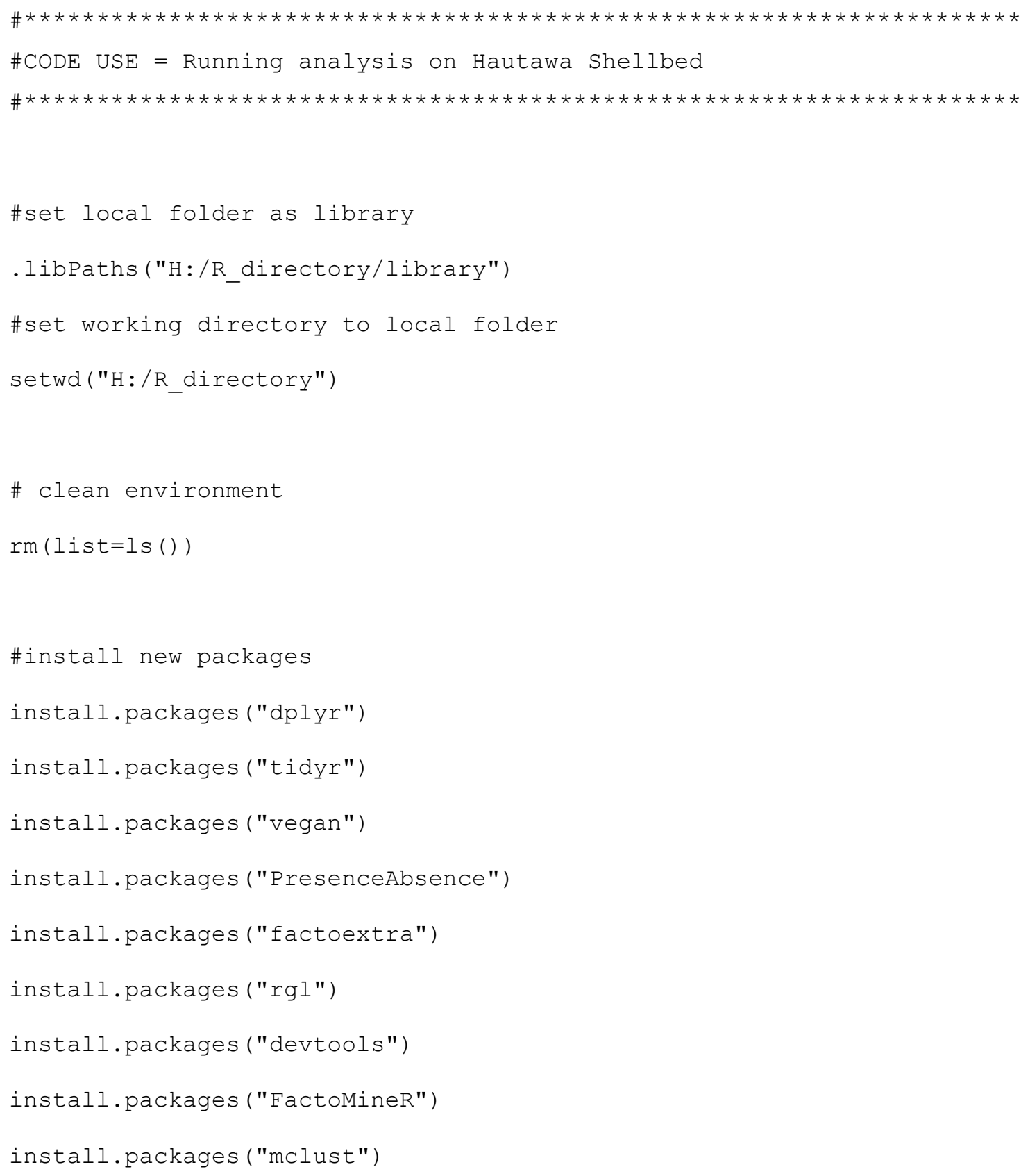


\#add packages to library

library (dplyr)

library (tidyr)

library (vegan)

library (PresenceAbsence)

library (factoextra)

library (rgl)

library (devtools)

library (FactoMineR)

library (mclust)

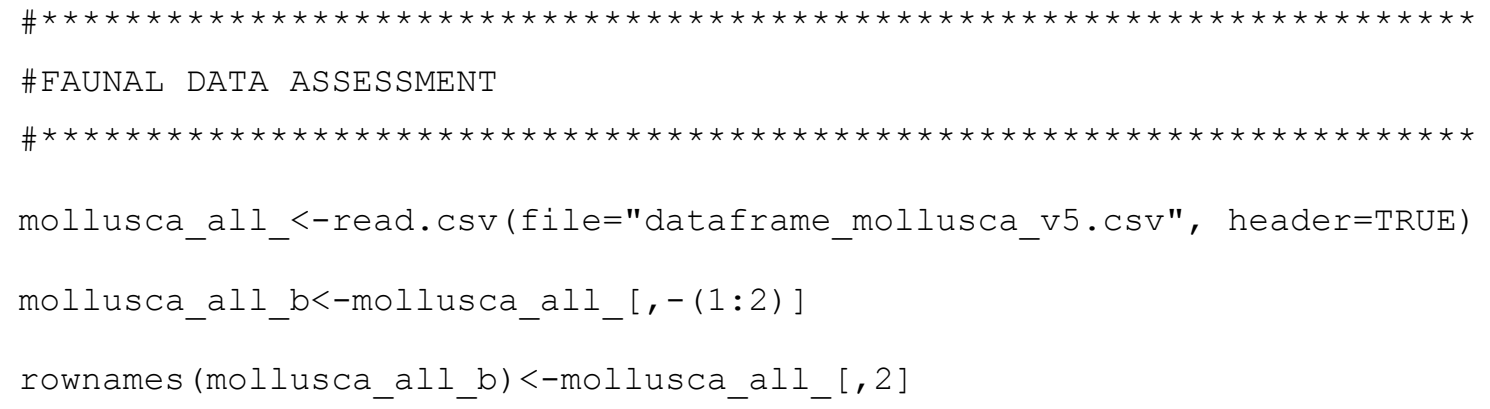




\section{APPENDIX}

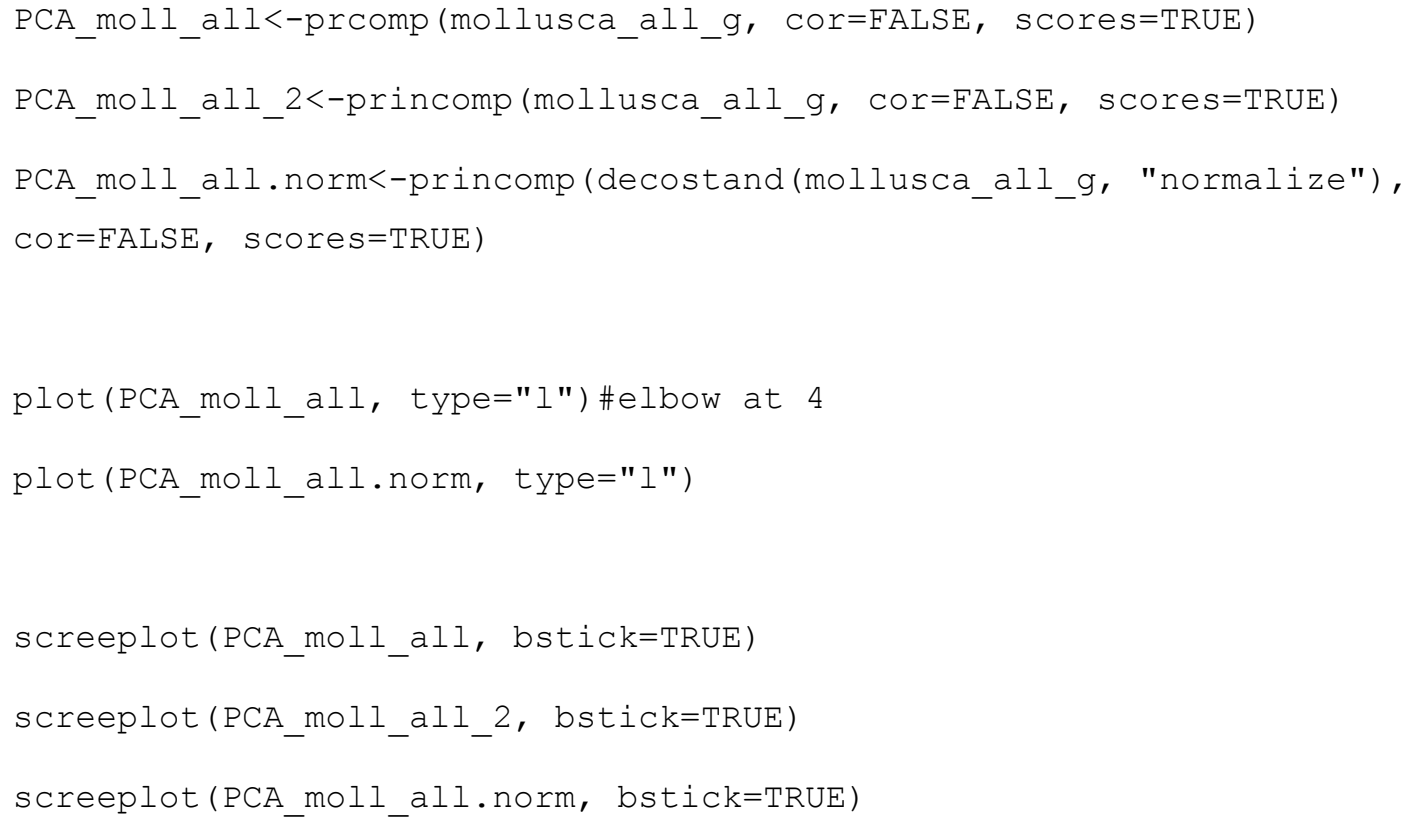


KM. fauna.norm. cas<-cascadeKM (fauna.norm, inf.gr=2, sup.gr=10, iter=10000, criterion = "calinski")

plot (KM.fauna.norm. cas, sortg=TRUE)

\#"The best partition is indicated by the highest SSI value." \#http://cc.oulu.fi/ jarioksa/softhelp/vegan/html/cascadekM.html \#take the lower peak to minimise number of clusters so 4

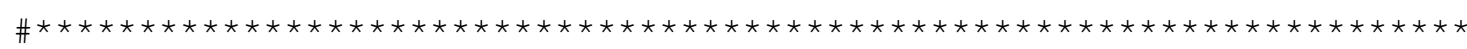
\#PRODUCE CLUSTERS ON PCA PLOT

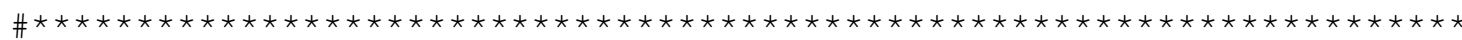

\#KMEANS

sig_components_f.norm<-data.frame(PCA_fauna.norm\$x $[, 1: 4])$

k_means_PCA_fauna.norm<-kmeans (sig_components_f.norm, 4, nstart=25, iter. $\max =10000$ )

fauna_kmeans.norm<-aggregate (mollusca_all_g,

by=list ( $k$ means_PCA_fauna.norm\$cluster), FUN=mean)

fauna_clusters.norm<-data.frame (mollusca_all_g,

k_means_PCA_fauna.norm\$cluster)

\#save file

write.csv(fauna_clusters.norm, "fauna_clusters_good.norm.csv", row $\cdot$ names=TRUE)

pdf ("Biplots_all_fauna_good.norm_0.95_NORM.pdf")

fviz_pca_biplot(PCA_moll_all.norm, axes=c $(1,2)$, title = "Biplot of PC1 and PC2", select.var=list (contrib=13), habillage=fauna_clusters.norm\$k_means_PCA_fauna.norm.cluster, addEllipses=TRUE, ellipse.level=0.95) + theme_minimal() 


\section{APPENDIX}

fviz_pca_biplot(PCA_moll_all.norm, axes=c $(2,3)$, title = "Biplot of PC2 and PC3", select.var=list (contrib=13), ha-

billage=fauna_clusters.norm\$k_means_PCA_fauna.norm.cluster, addEllipses=TRUE, ellipse.level=0.95) + theme_minimal()

fviz_pca_biplot (PCA_moll_all.norm, axes=c(1,3), title = "Biplot of PC1 and PC3", select.var=list (contrib=13), habillage=fauna_clusters.norm\$k_means_PCA_fauna.norm.cluster, addEllipses=TRUE, ellipse.level=0.95) + theme_minimal()

$\operatorname{dev} \cdot \operatorname{off}()$

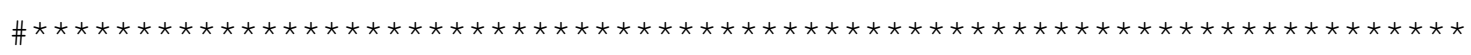

\#TAPHONOMIC DATA ASSESSMENT

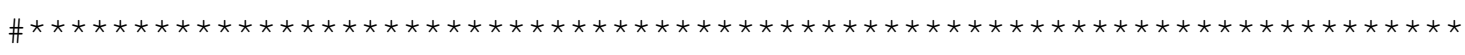

\#Read in raw csv file of presence absence

mollusca_all<-read.csv(file="dataframe_mollusca_v5.csv", header=TRUE)

\#Subset down to just taphonomy

tapho_all<-mollusca_all[ , c $(1: 8,30: 35)]$

tapho_only<-tapho_all $[, 9: 14]$

\# set row names to samples at sites

rownames (tapho_only) <-tapho_all $[$,2]

\#remove empty data

tapho_only_b<-tapho_only $[-(\mathrm{c}(4,16,23,24,40))$, ]

\#subset down to just $P$ S D F

tapho_only_d<-tapho_only_b $[,-c(1,6)]$

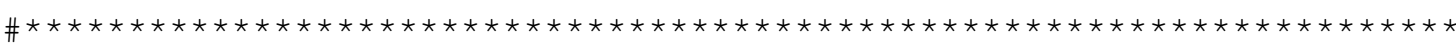

\#MULTIFACTOR ANALYSIS 
\#a side effect of using the mfa() function is the production of a data frame which is of presence-absence style for the categorical taphonomic data. This makes it possible to run PCA etc as with the faunal data on the taphonomic data set also MFA_tapho<-MFA (tapho_only_d, $\operatorname{group}=\mathrm{C}(\operatorname{rep}(1,4)), \operatorname{type}=\mathrm{c}(\operatorname{rep}(" \mathrm{n} ", 4))$, ncp $=5$, name.group=c ("P", "S", "D", "F")) summary (MFA_tapho) barplot (MFA_tapho\$eig[,1], main="Eigenvalues", names.arg=1:nrow (MFA_tapho\$eig))

MFA_PA_P<-MFA_tapho\$separate.analyses\$P\$call\$Xtot MFA_PA_S $<-M F A \_t a p h o \$ s e p a r a t e . a n a l y s e s \$ S \$ c a l l \$ X t o t$ MFA_PA_D<-MFA_tapho\$separate.analyses\$D $\$$ call $\$ X t o t$ MFA_PA_F $<-M F A$ tapho\$separate.analyses $\$ F \$ c a l l \$ X t o t$

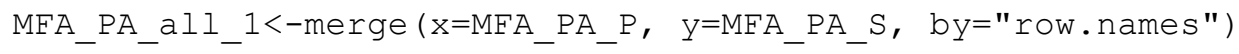

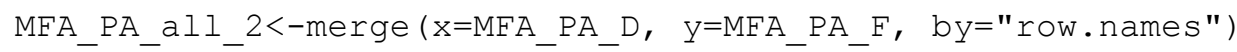

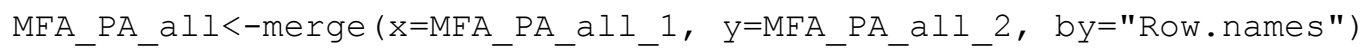

MFA_PA_all_b $<-M F A \_P A \_a l l[,-1]$

rownames (MFA_PA_all_b) $<-M F A \_P A \_a l l[, 1]$

MFA_PA_all_c<-MFA_PA_all_b $[,-c(1,9,16,24)]$

\#this data frame is the end result needed to run PCA

\#save file

write.csv(MFA_PA_all_c,"tapho_data.csv", row.names=TRUE)

PCA_tapho_all<-prcomp (MFA_PA_all_c, cor=FALSE, scores=TRUE)

fviz_pca_var(PCA_tapho_all, axes=c $(1,2)$, select.var=list $($ contrib=13))

+ theme_minimal ()

fviz_pca_ind(PCA_tapho_all, axes=c $(1,2)$, select.var=list (contrib=13))

+ theme_minimal () 


\section{APPENDIX}

fviz_pca_biplot (PCA_tapho_all, axes=c $(1,2)$, select.var=list (contrib=13)) + theme_minimal ()

plot(PCA_tapho_all, type="l") \#4 PC's significant i.e. 'elbow' is at 4

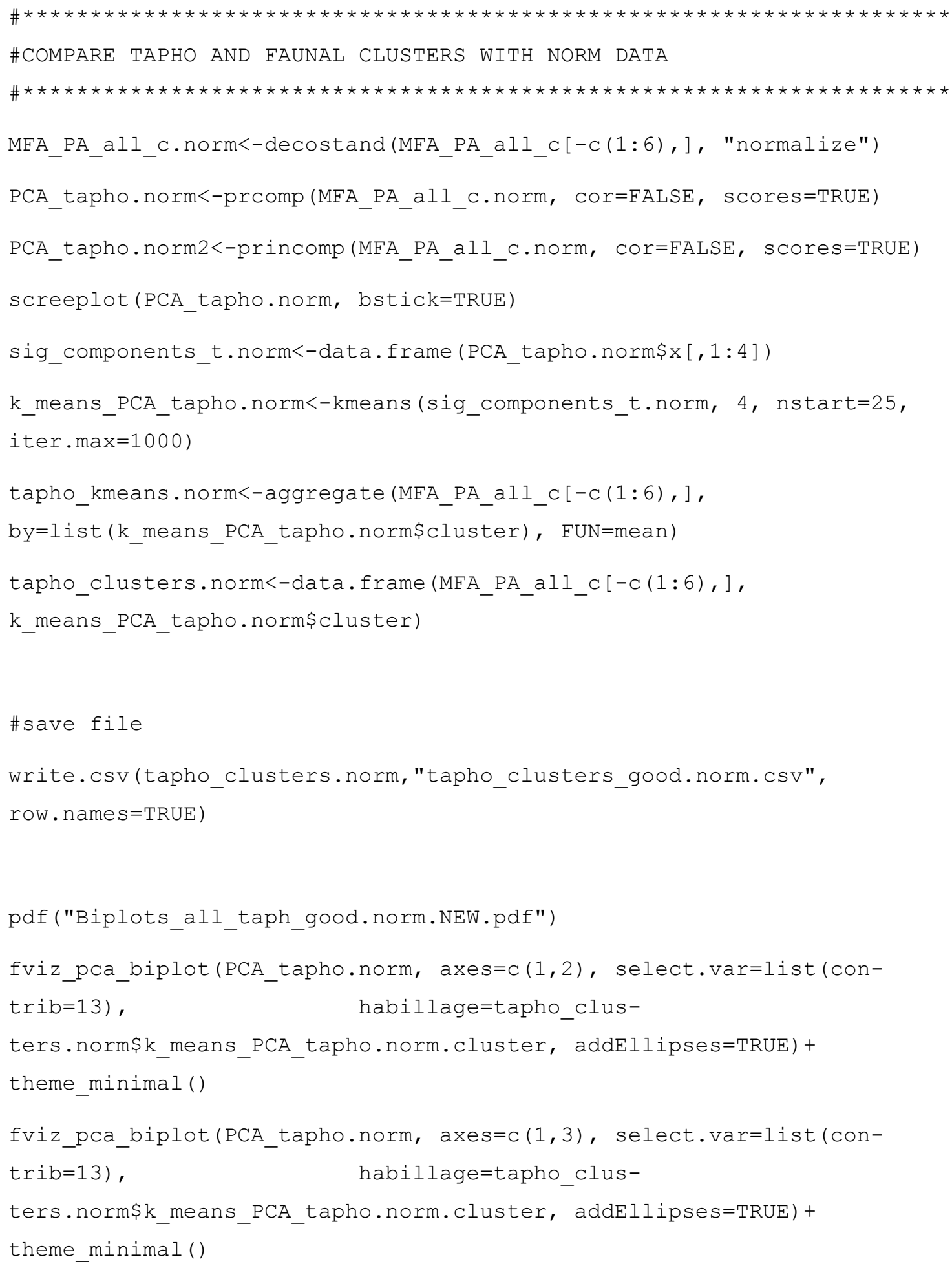


fviz_pca_biplot(PCA_tapho.norm, axes=c $(2,3)$, select.var=list (con-

trib=13), habillage=tapho_clus-

ters.norm\$k_means_PCA_tapho.norm.cluster, addEllipses=TRUE) +

theme_minimal ()

dev. off ( )

tapho.norm<-decostand(MFA_PA_all_c.norm, "normalize")

PCA_tapho.norm<-prcomp (tapho.norm, cor=FALSE, scores=TRUE)

KM.tapho.norm<-cascadeKM(tapho.norm, inf.gr=2, sup.gr=5, iter=10000, criterion = "ssi")

plot (KM.tapho.norm, sortg=TRUE)

\#add tapho clusters to fauna

clusters_tapho_good.norm<-as.vector(tapho_clusters.norm [ ,25])

moll_good.norm<-mollusca_all_g

moll_good_taph.norm<-merge(moll_good.norm, tapho_clusters.norm,

by $\cdot x=$ "row. names", by. $y=$ "row.names", all.x=TRUE)

\#save file

write.csv(moll_good_taph.norm, "dataframe_good.norm.csv",

row . names=TRUE)

\# set row names to samples at sites

moll_good_taph_2<-moll_good_taph.norm $[,-(1)]$

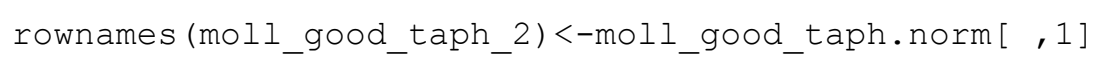

\#rerun PCA on fauna and plot with tapho clusters

\#normalize mol data first = chord transformation :)

moll_good_taph_2.norm<-decostand (moll_good_taph_2 [ , 1:13], "normalize")

PCA_moll_2.norm<-prcomp (moll_good_taph_2.norm, cor=FALSE, scores=TRUE) 


\section{APPENDIX}

fviz_pca_biplot (PCA_fauna.norm, axes=c $(1,2)$, select.var=list (con-

trib=10), ha-

billage=moll_good_taph_2\$k_means_PCA_tapho.norm.cluster, addEllip-

ses=TRUE) + theme_minimal ()

\#DOESN'T APPEAR TO BE A CORRELATION BETWEEN TAPHO CLUSTERS AND FAUNA OBSERVED

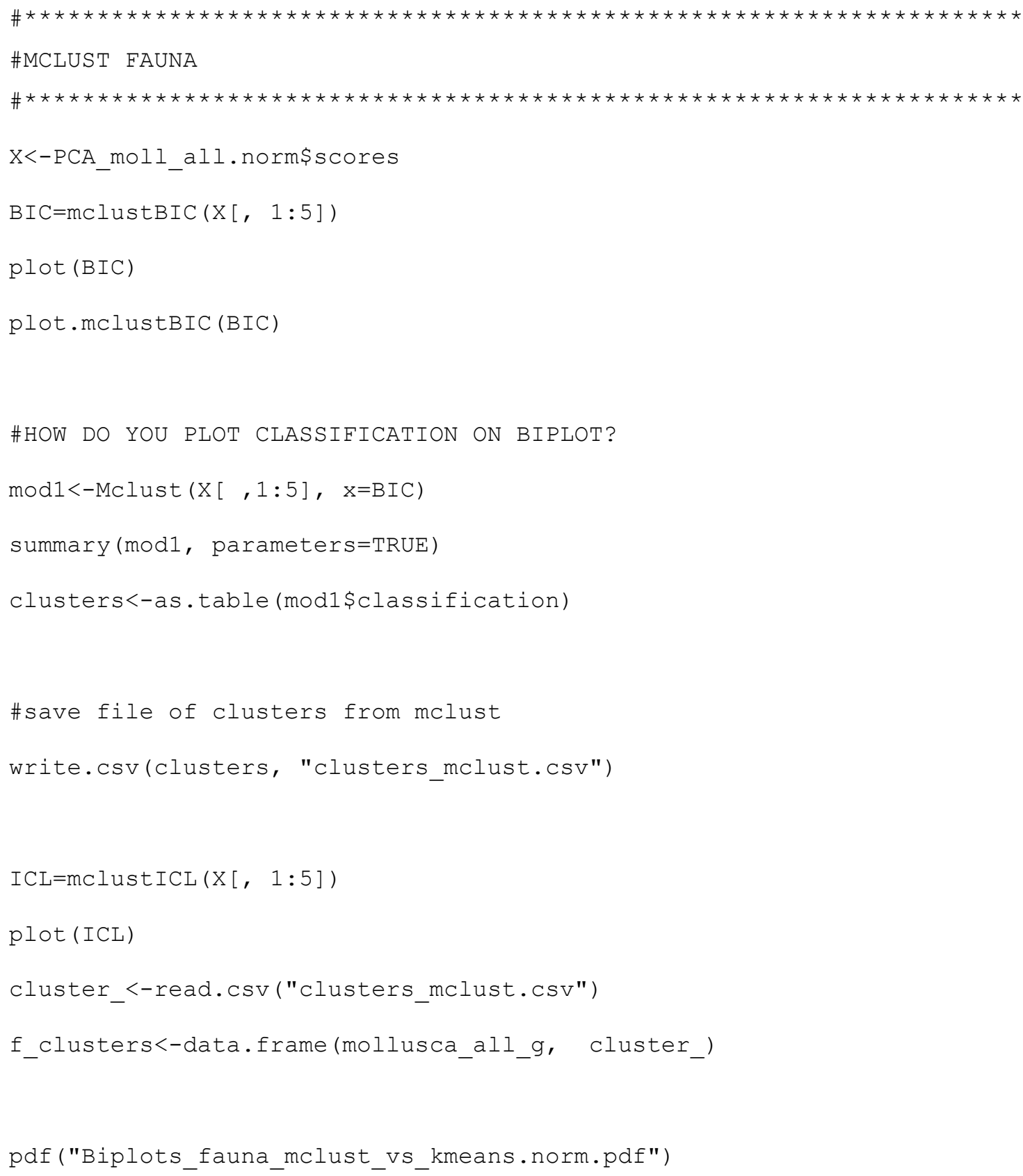




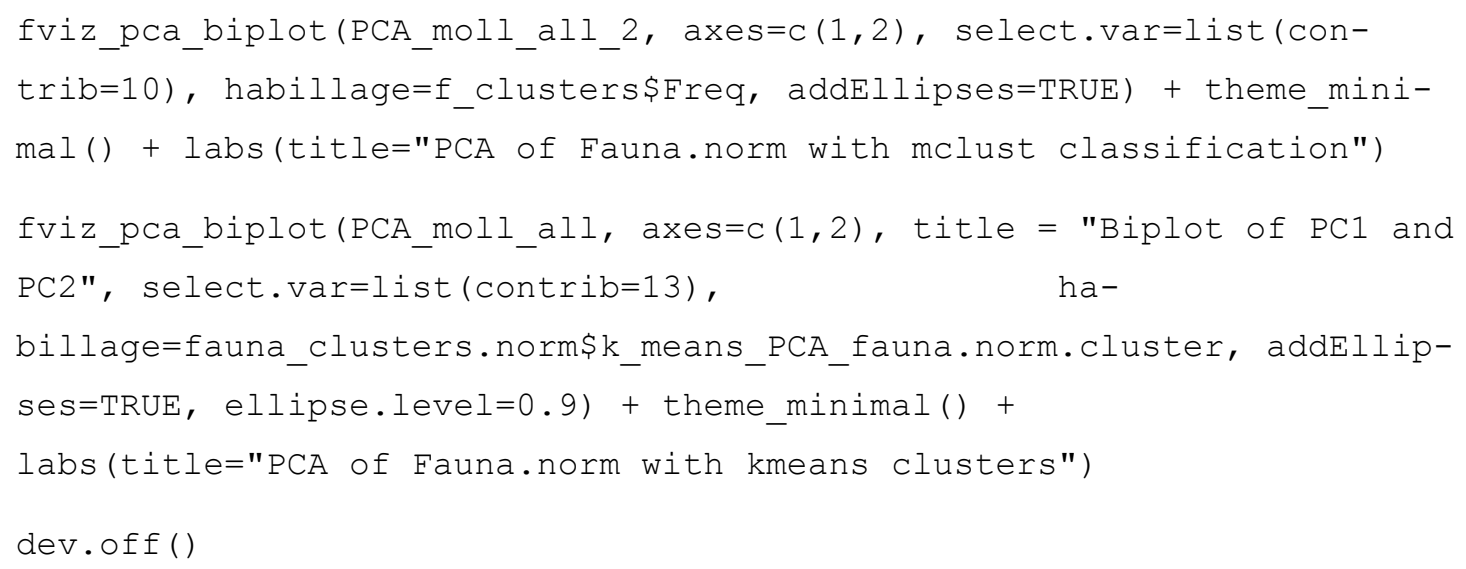

\section{A.4.2 Comparison of mclust and kmeans partitioning}

As described in the text, a parsimonious approach chooses four clusters using kmeans clustering, even though the ssi criterion peaked at six clusters rather than four (Oksanen et al., 2007). This is further supported by considering the outcomes of partitioning using the function mclust (Fraley \& Raftery, 2006). While mclust does produce six clusters for the dataset they are not an even break down into six dominant clusters, but four dominant and two very minor clusters [Figs. A.4.1 and A.4.2]. This is shown by two clusters with only 3 points each (clusters 4 and 5). While the other four have: 10 points (cluster 1), 13 points (cluster 2), 7 points (cluster 3 ), and 15 points (cluster 6). Therefore, six clusters do not show six major trends in the dataset, and four partitions is preferable to six. Cluster 2 as designated by mclust is also strange in that it is completely spread-out on both principal component (PC) 1 and 2 [Fig. A.4.1].

In contrast, the four clusters that kmeans partitions the dataset into appear to be a better balance [Figs. A.4.3 and A.4.4]. There are 12 points in cluster 1, 10 points in cluster 2, 15 points in cluster 3, and 14 points in cluster 4 . Here, the clusters and point assignment into the clusters are the same as presented in the text, but arranged on the same principal component (PC) plot as done with mclust. 
APPENDIX

The table below [Table A.4.1] compares the partitioning using kmeans and mclust in order to emphasise how the mclust six clusters does not divide the dataset in a balanced way into dominant trends.

Table A.4.1: Comparison of mclust and kmeans partitioning and the breakdown of number of points placed into each cluster out of the total 51 points.

\begin{tabular}{c|c|c} 
mclust & $\#$ & $\%$ \\
\hline 1 & 10 & $20 \%$ \\
2 & 13 & $25 \%$ \\
3 & 7 & $14 \%$ \\
4 & 3 & $6 \%$ \\
5 & 3 & $6 \%$ \\
6 & 15 & $29 \%$ \\
\hline \hline
\end{tabular}

\begin{tabular}{c|c|c} 
kmeans & $\#$ & $\%$ \\
\hline 1 & 12 & $24 \%$ \\
2 & 10 & $20 \%$ \\
3 & 15 & $28 \%$ \\
4 & 14 & $28 \%$ \\
\hline \hline
\end{tabular}


Figure A.4.1: Bi-plot of mclust partitioning of faunal assemblage dataset into six clusters. Clusters 2 and 3 shown here.

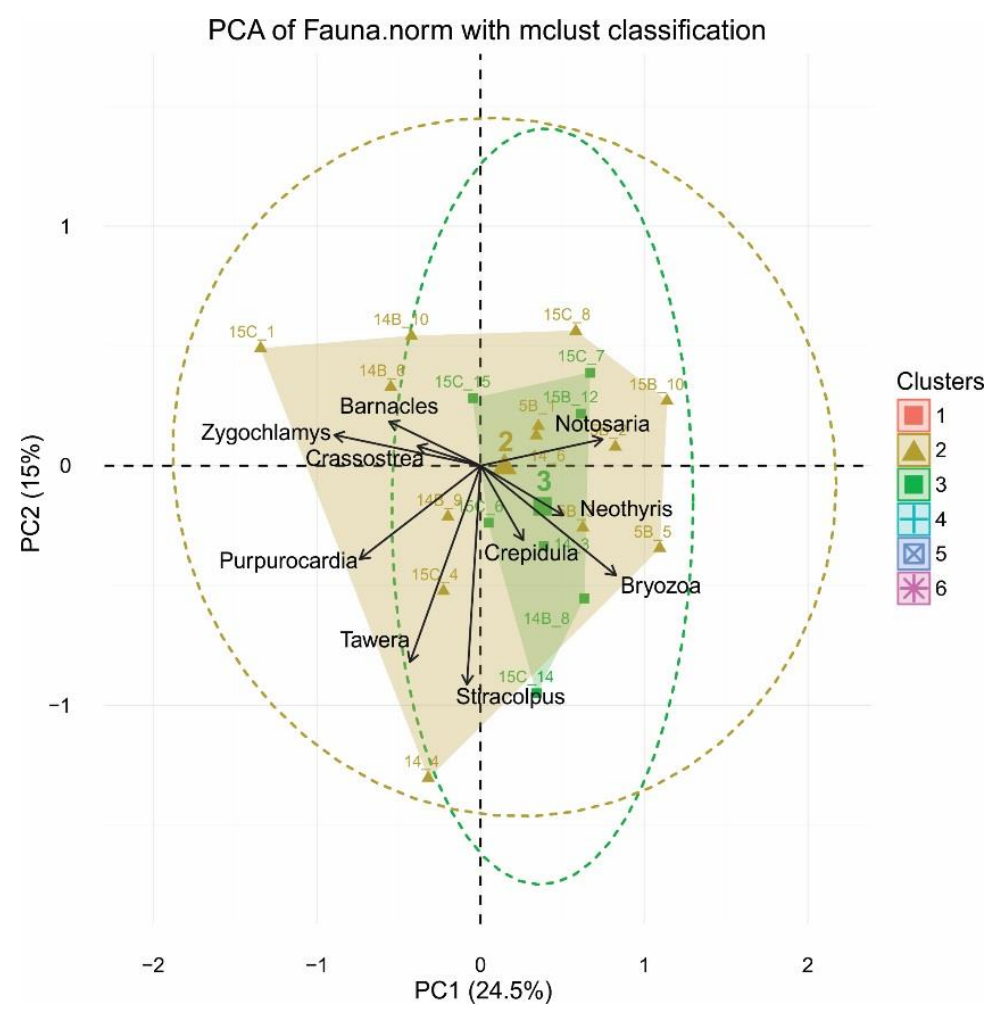

Figure A.4.2: Bi-plot of mclust partitioning of faunal assemblage dataset into six cluster. Clusters 1, 4, 5, and 6 shown here.

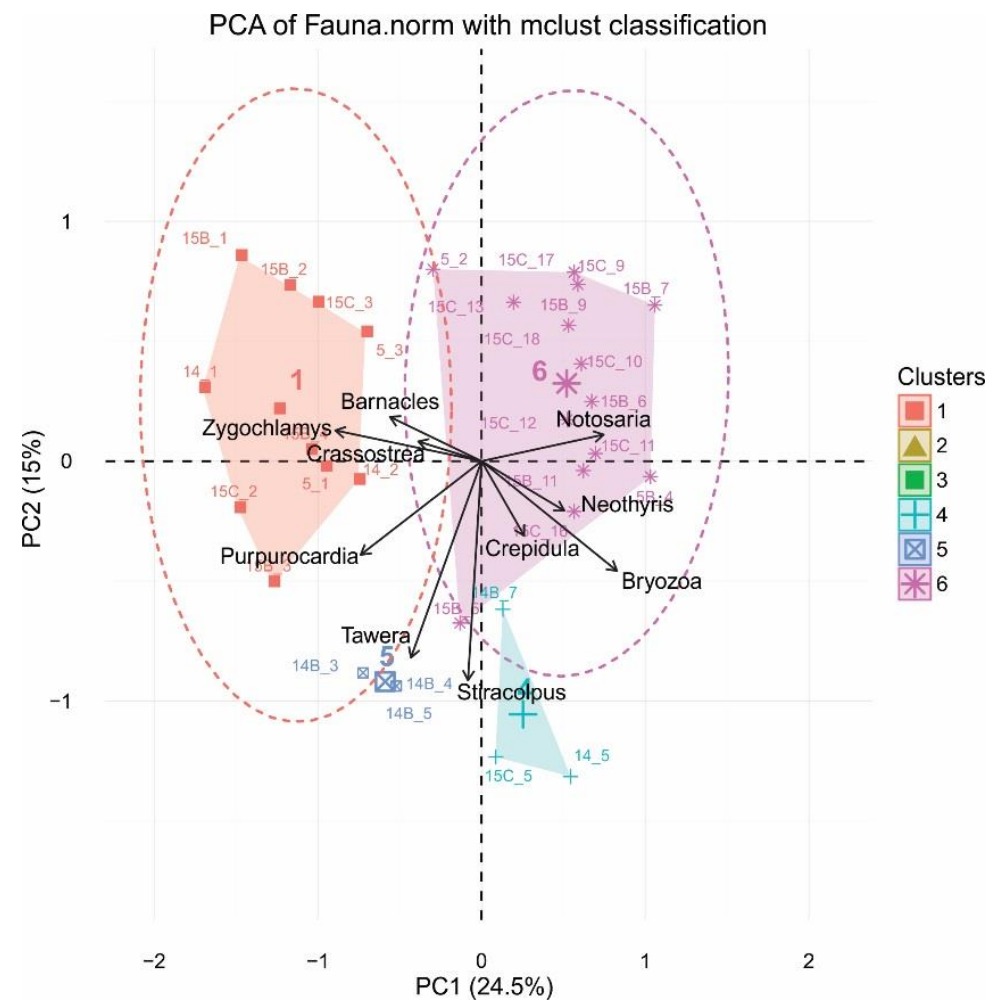


Figure A.4.3: Bi-plot of kmeans partitioning of faunal assemblage dataset into six cluster. Clusters 1 and 2 shown here.

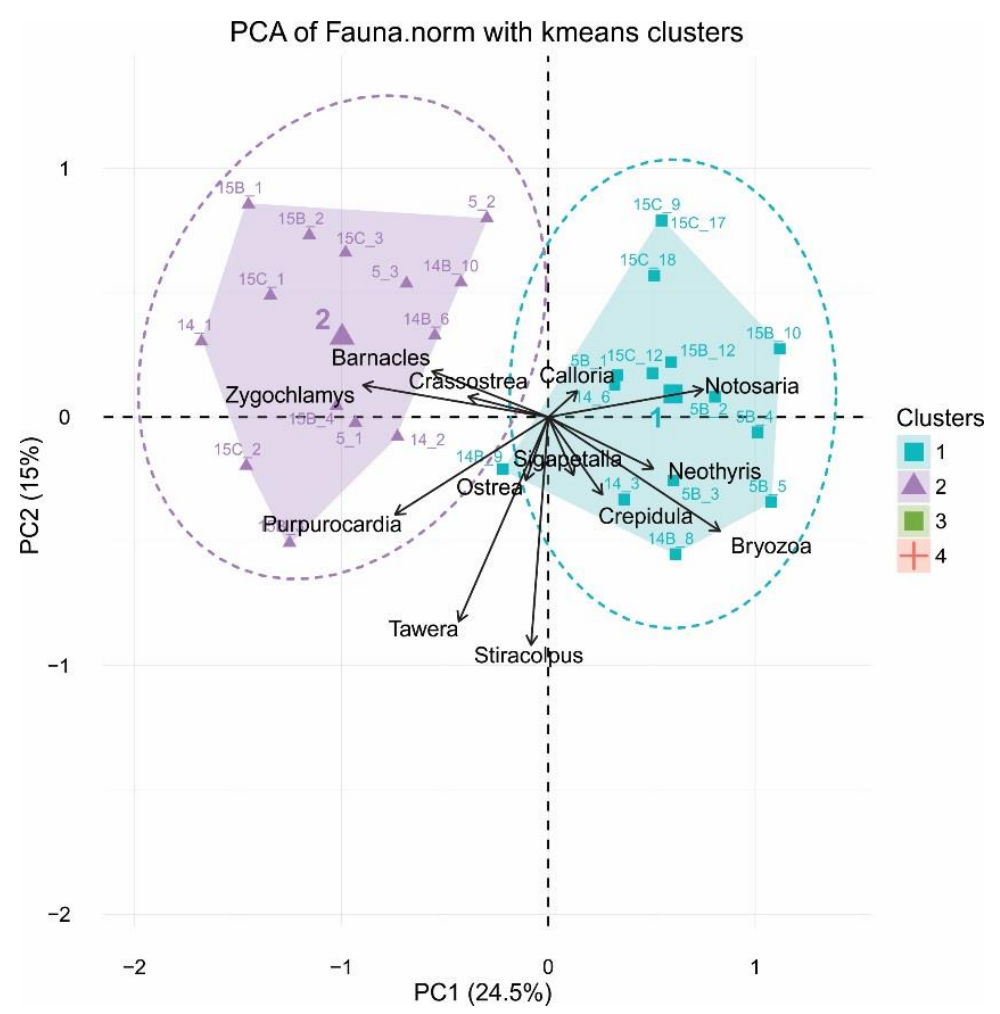

Figure A.4.4: Bi-plot of kmeans partitioning of faunal assemblage dataset into six cluster. Clusters 2 and 4 shown here.

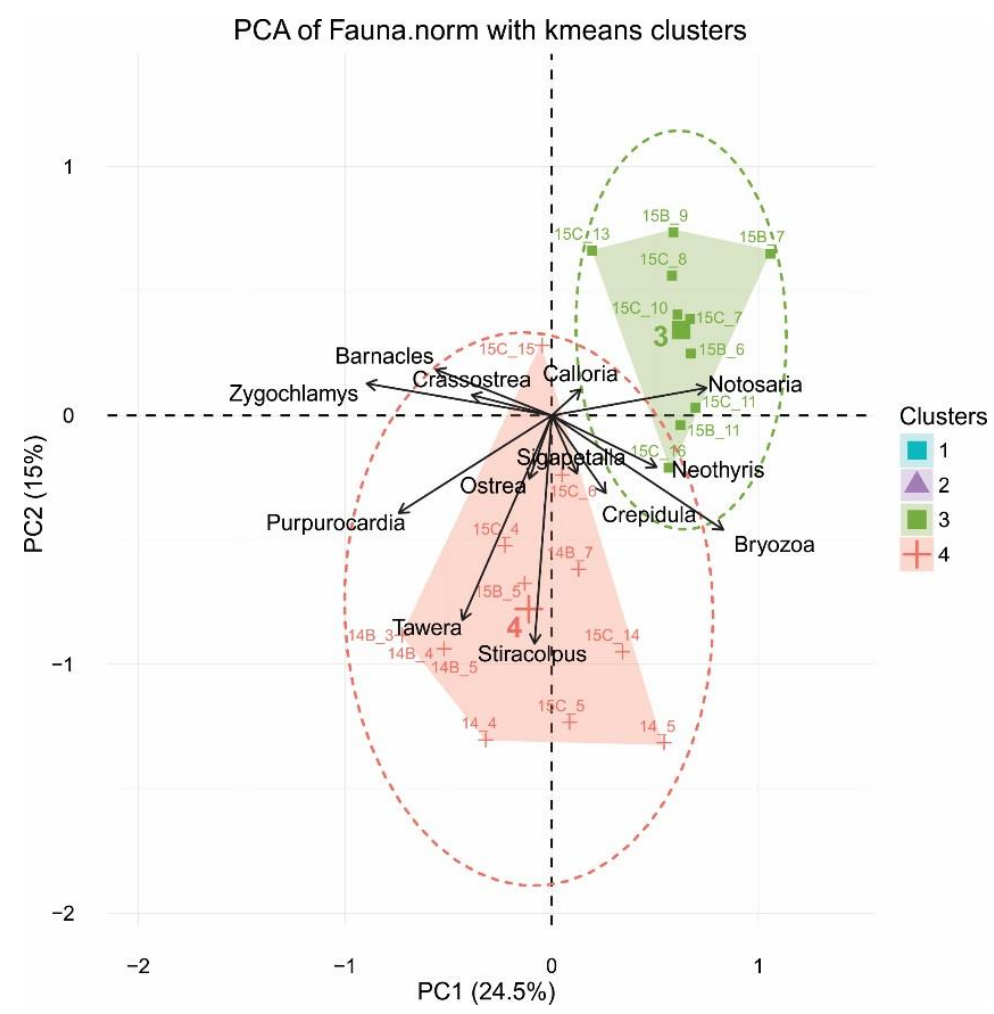




\section{A.5 R CODE: FORAMINIFERA}

This code is used to produce, in unedited form, the following figures:

- Figures 5.2.1-5.2.2

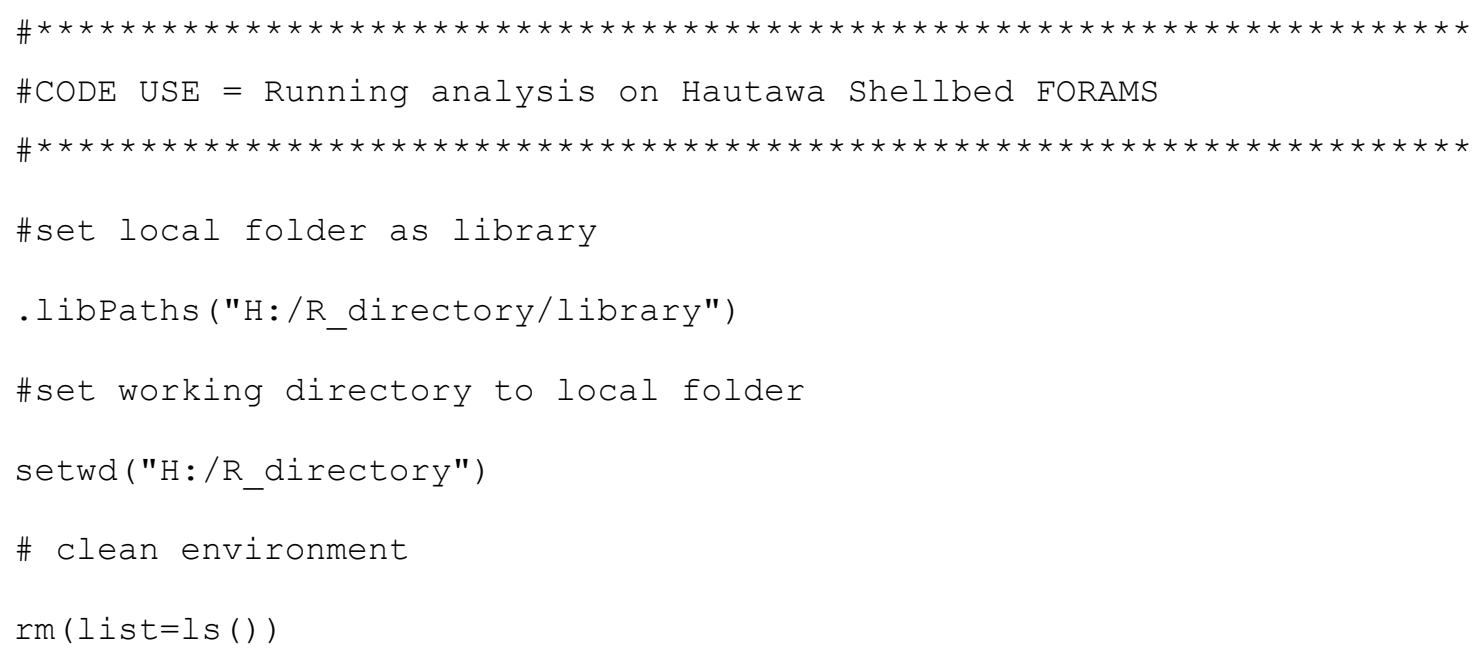




\section{APPENDIX}

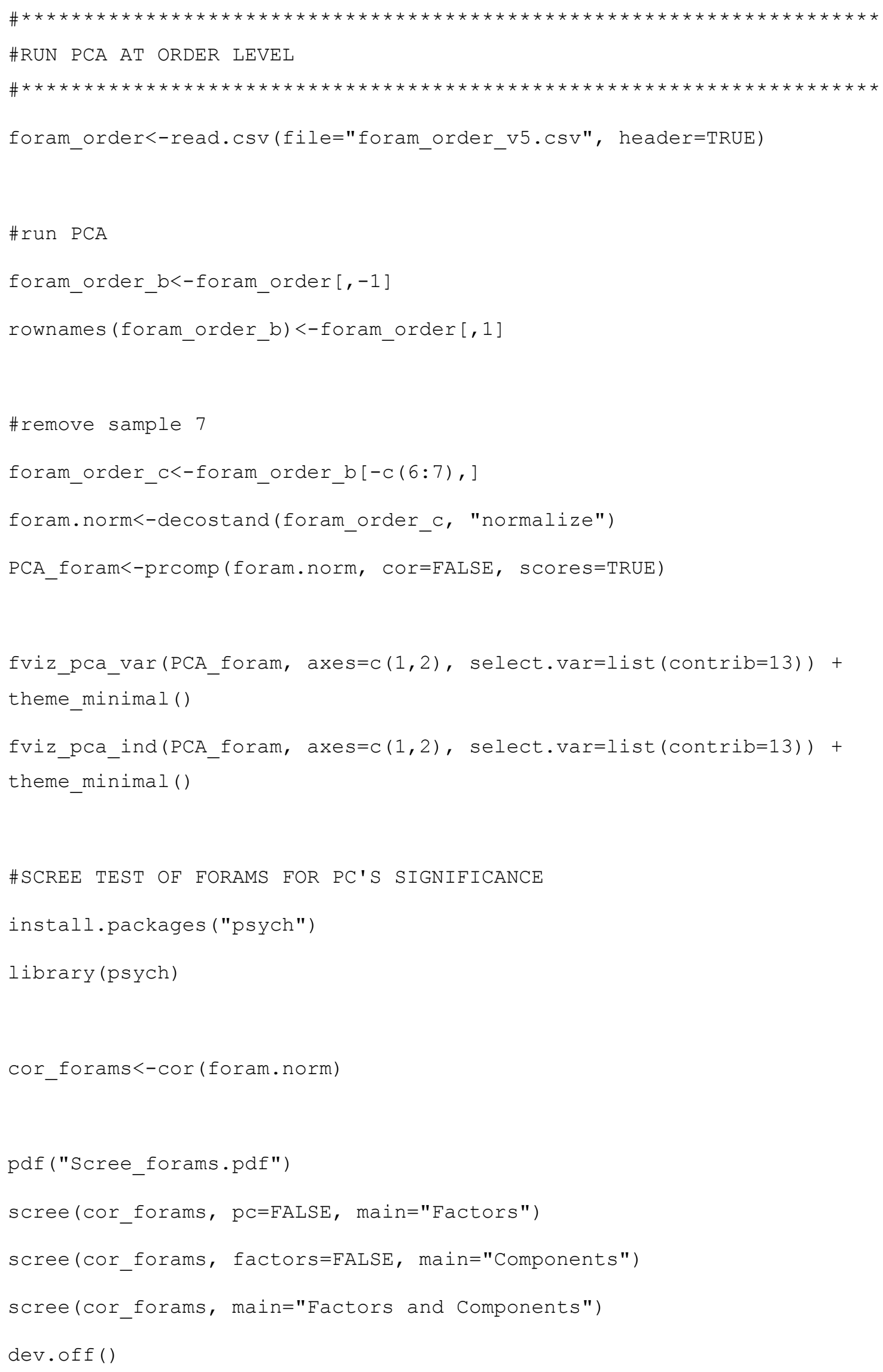


plot(PCA_foram, type="l") \#2 PC's significant i.e. 'elbow' is at 2

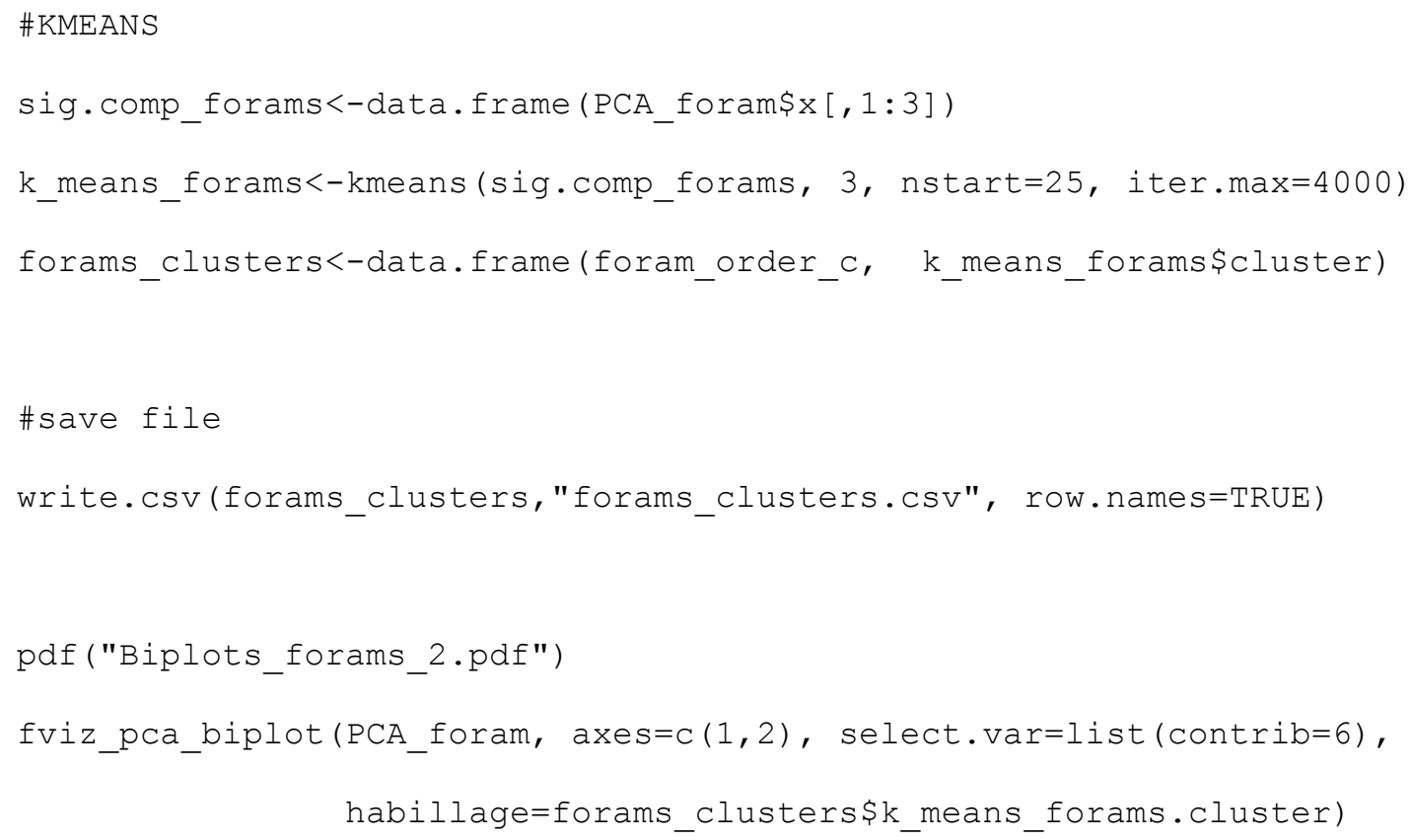




\section{APPENDIX}

PCA_foram_gen<-prcomp ((decostand(foram_genera_d, "normalize")), cor=FALSE, scores=TRUE)

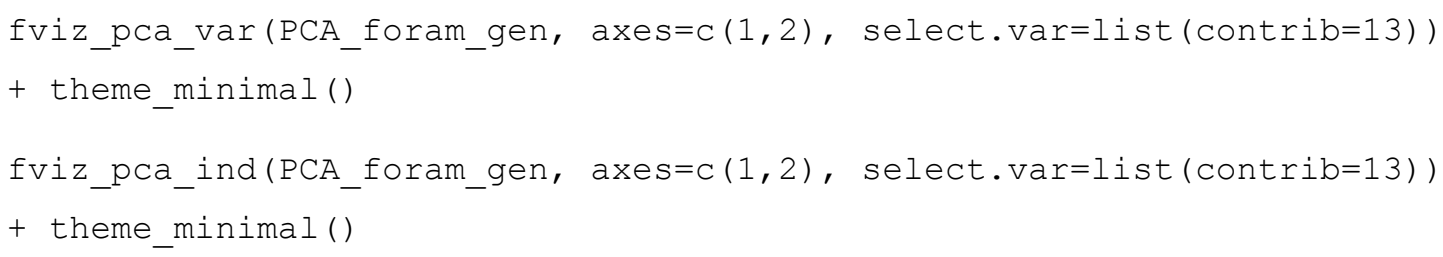


APPENDIX

foram.norm<-decostand(foram_genera_d, "normalize")

\#try between 2 and 6 groups and show criterion SSI = three groups key is stable

KM.foram<-cascadeKM(foram.norm, inf.gr=2, sup.gr=6, iter=10000, criterion="ssi" )

plot (KM.foram, sortg=TRUE) 


\section{A.6 FORAMINIFERA WATER DEPTH ASSESSMENT}

\section{A.6.1 Faunal Assemblage by Order}
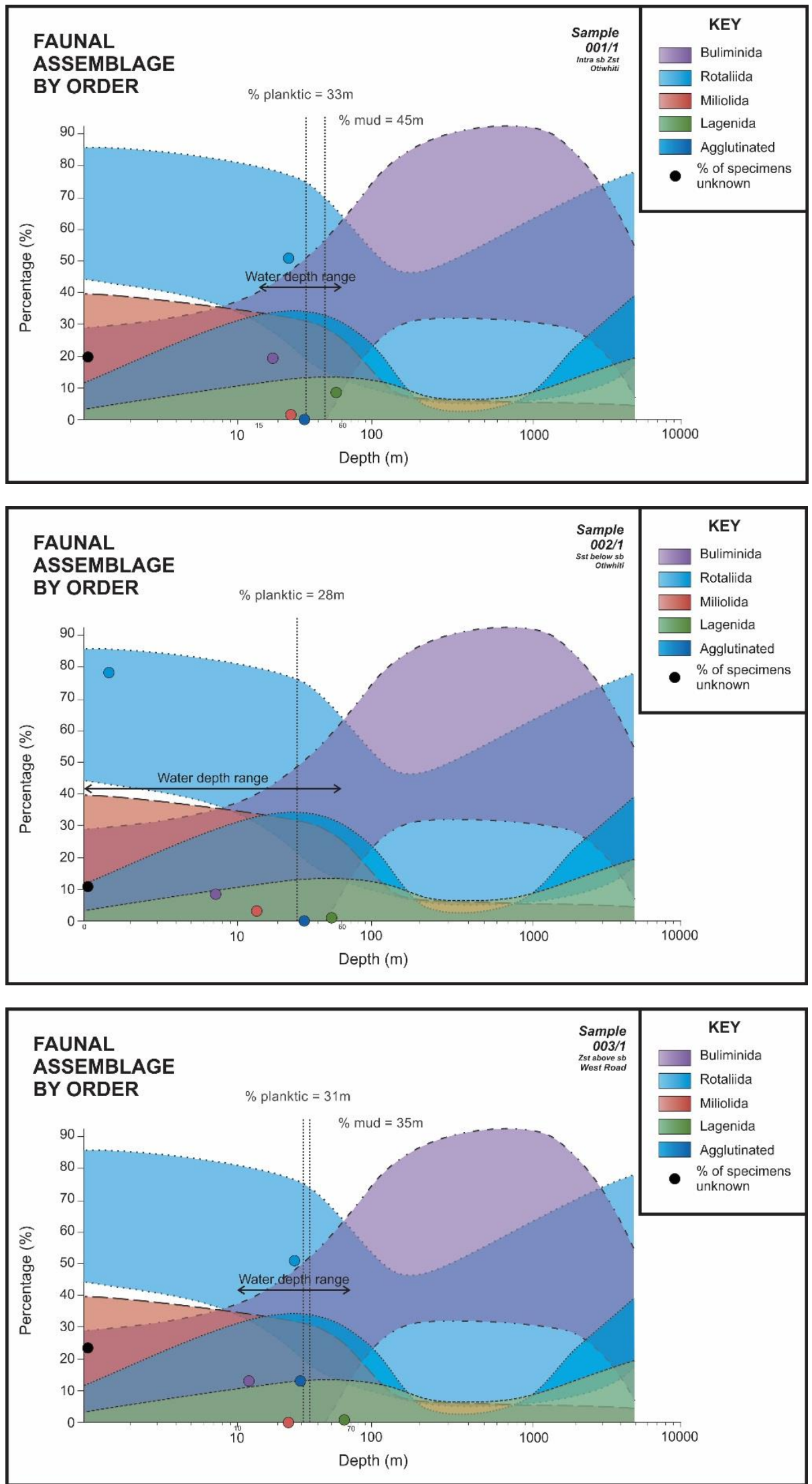

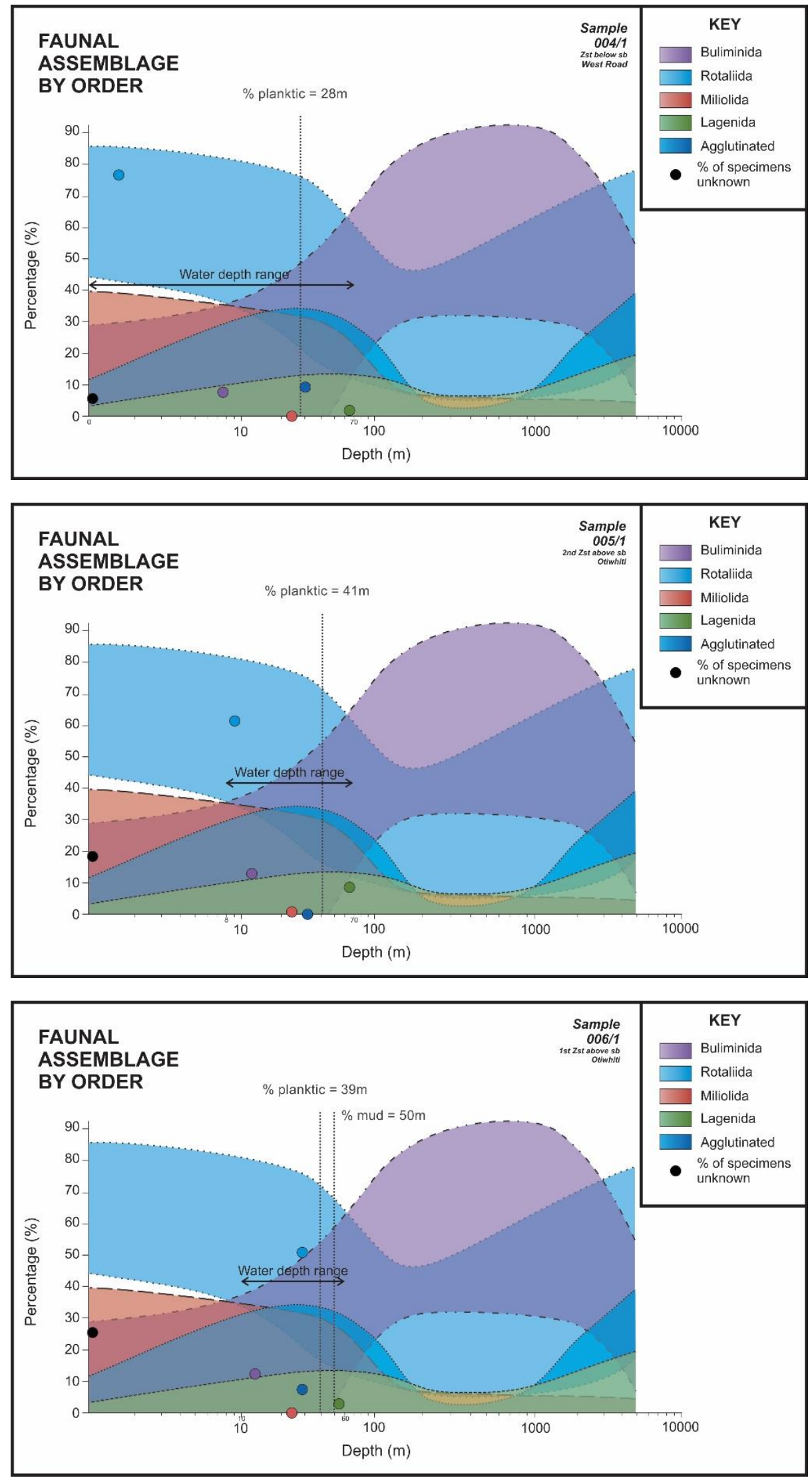

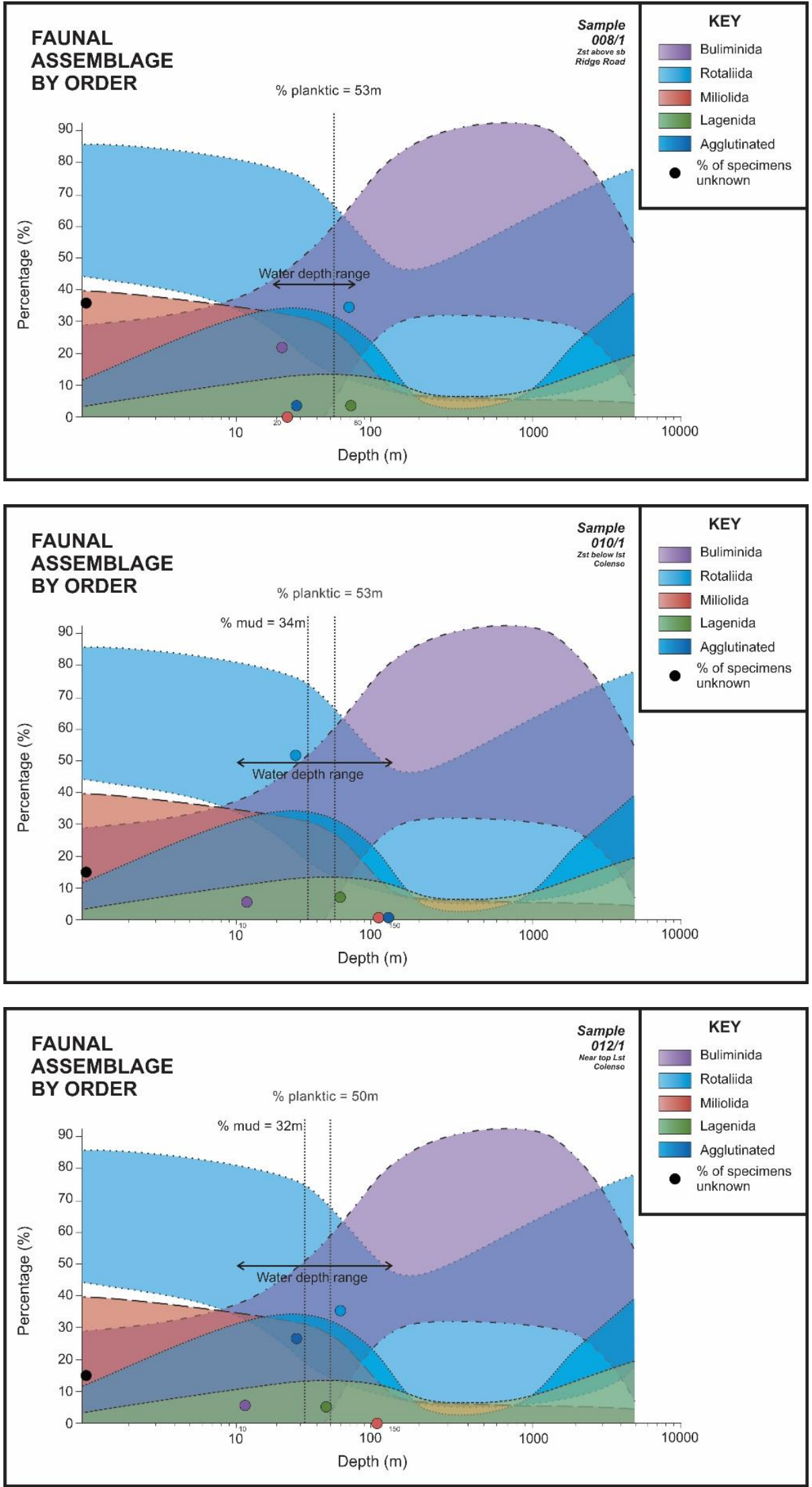

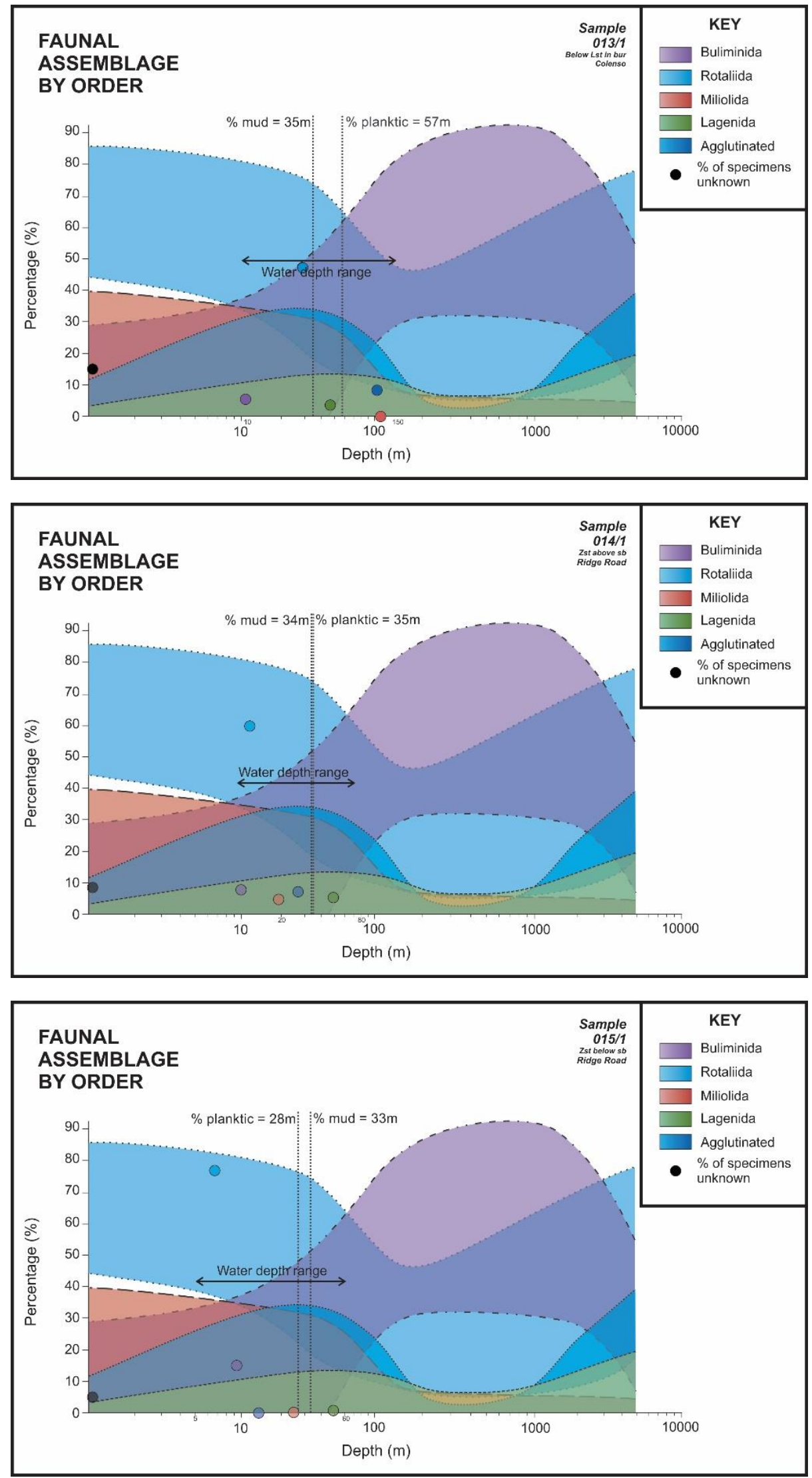
A.6.2 Faunal Assemblage by Genera
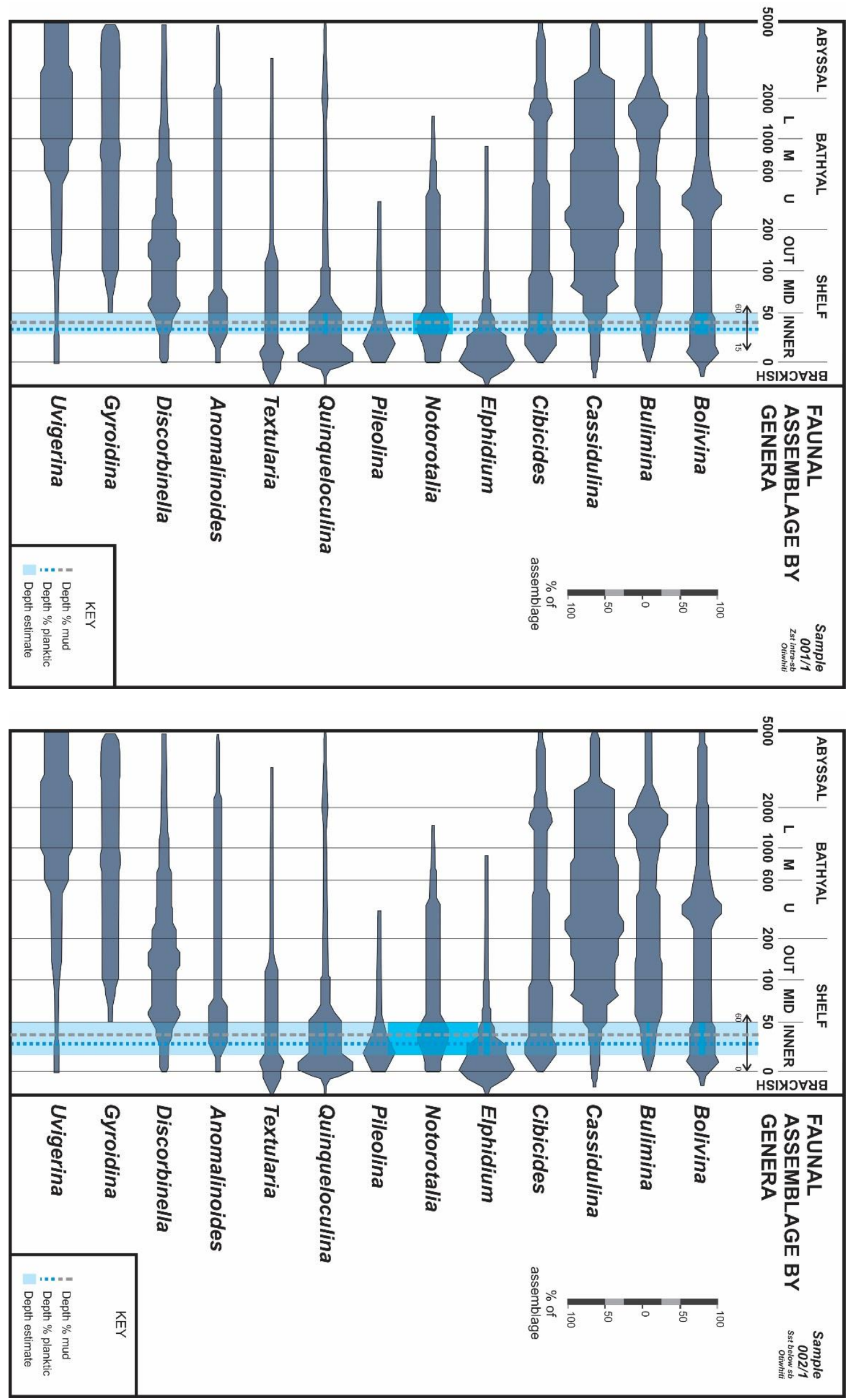

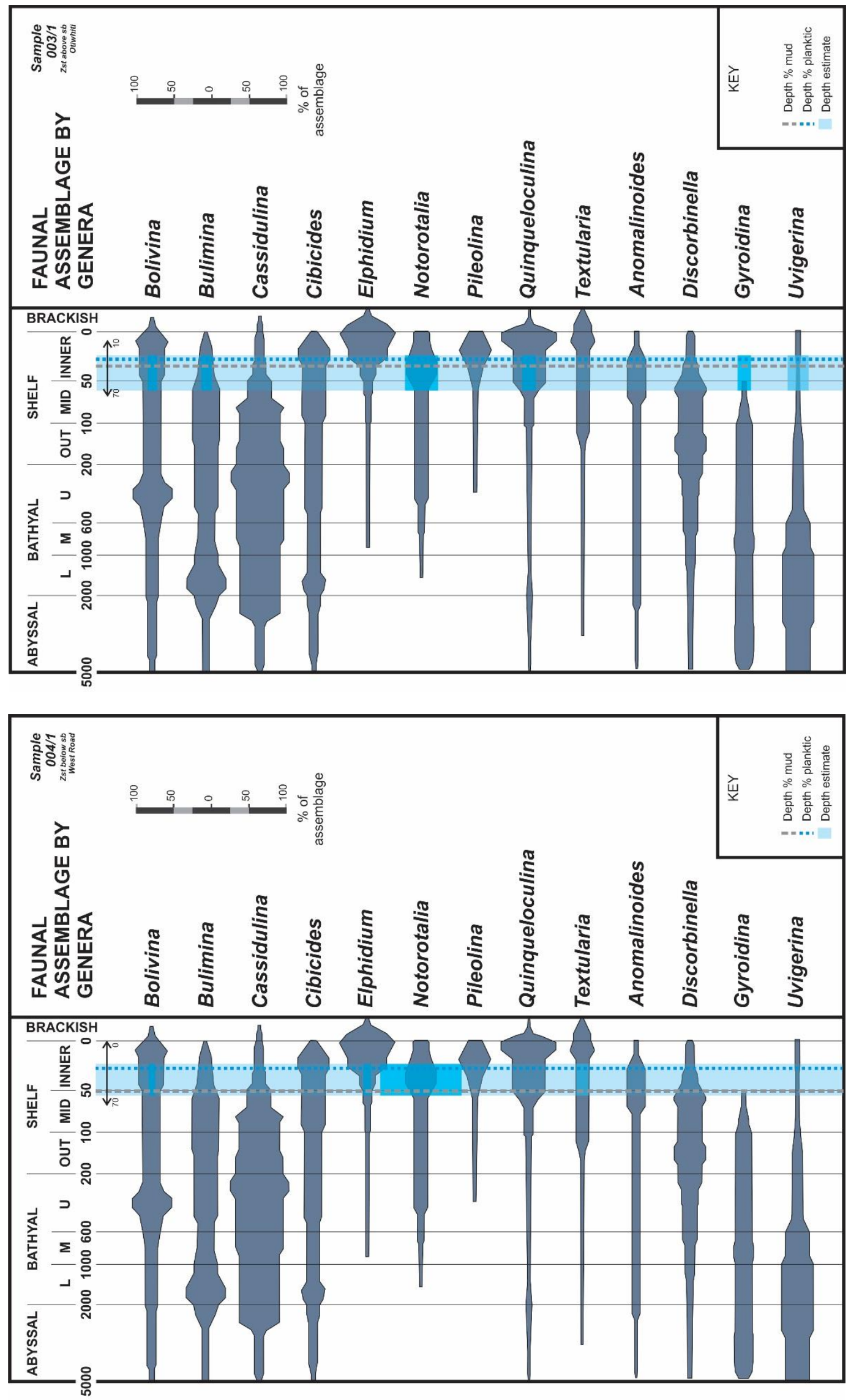

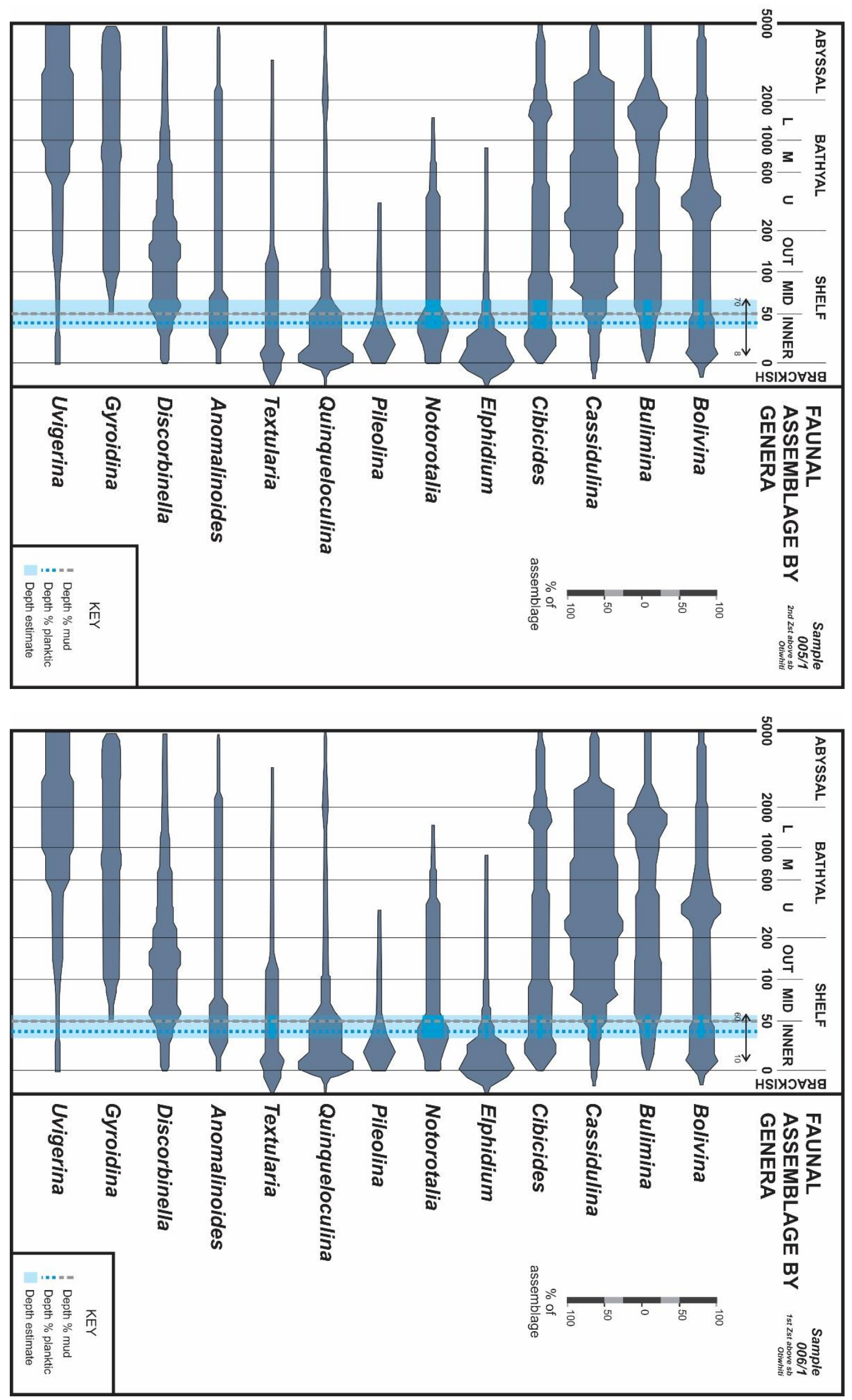

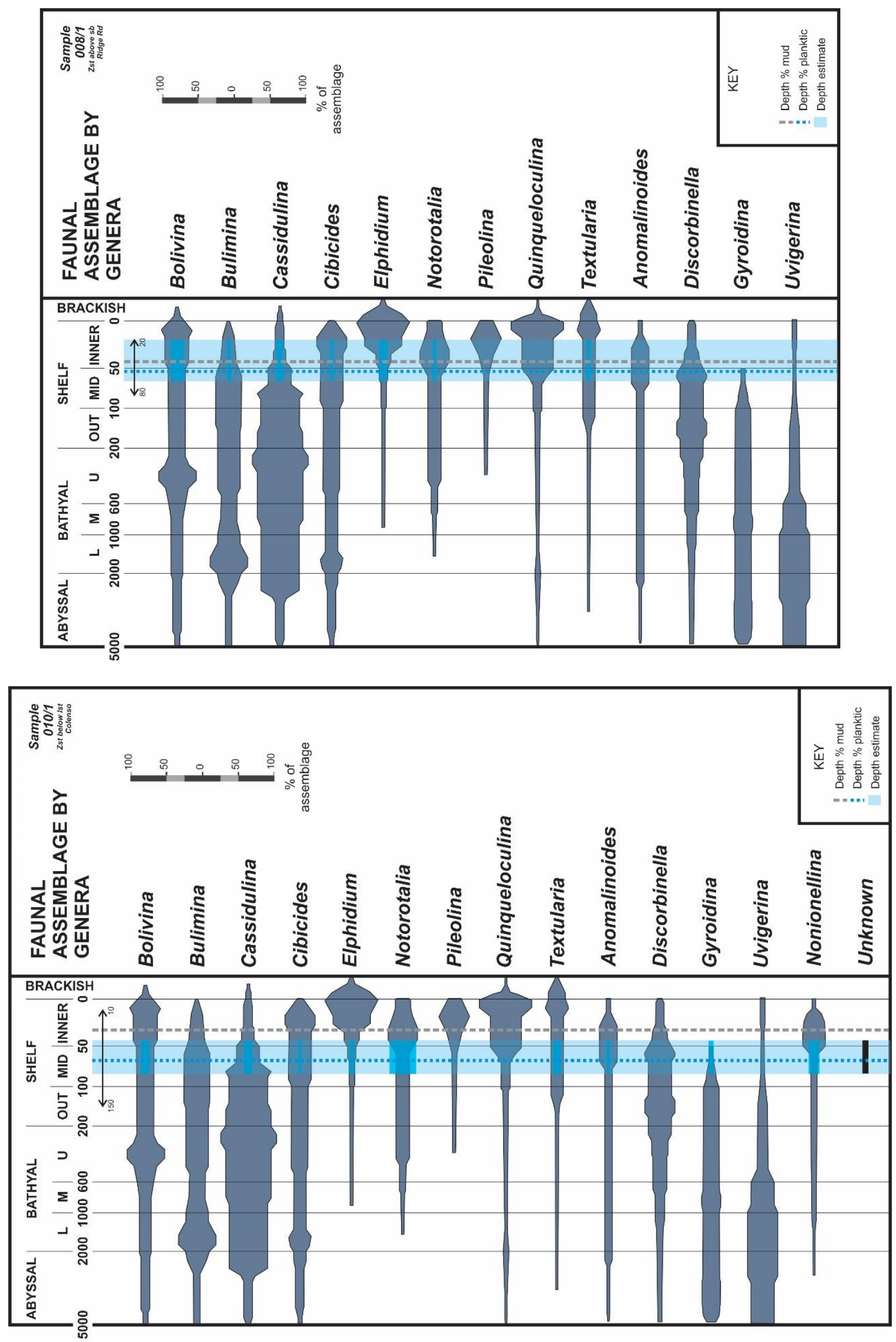

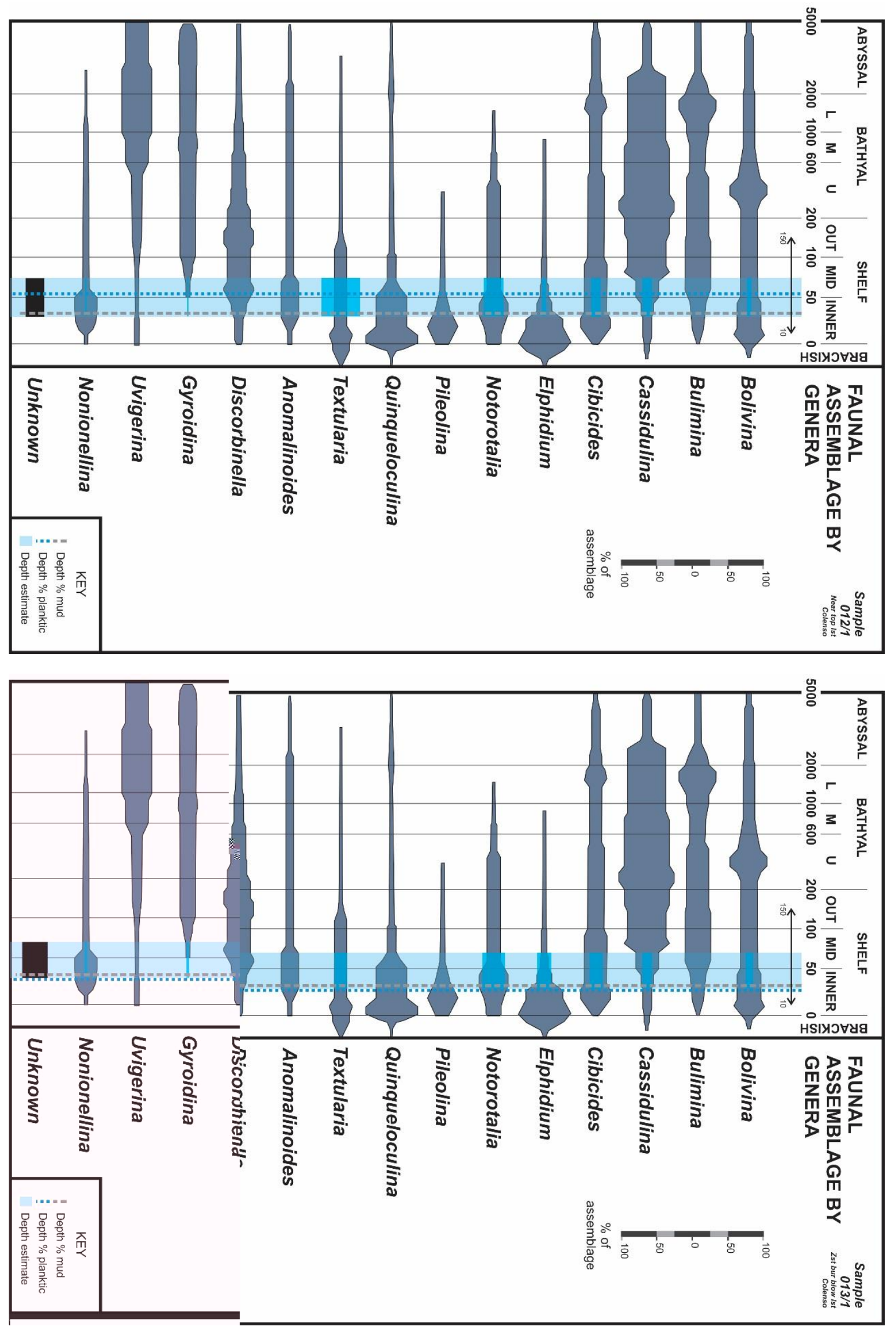

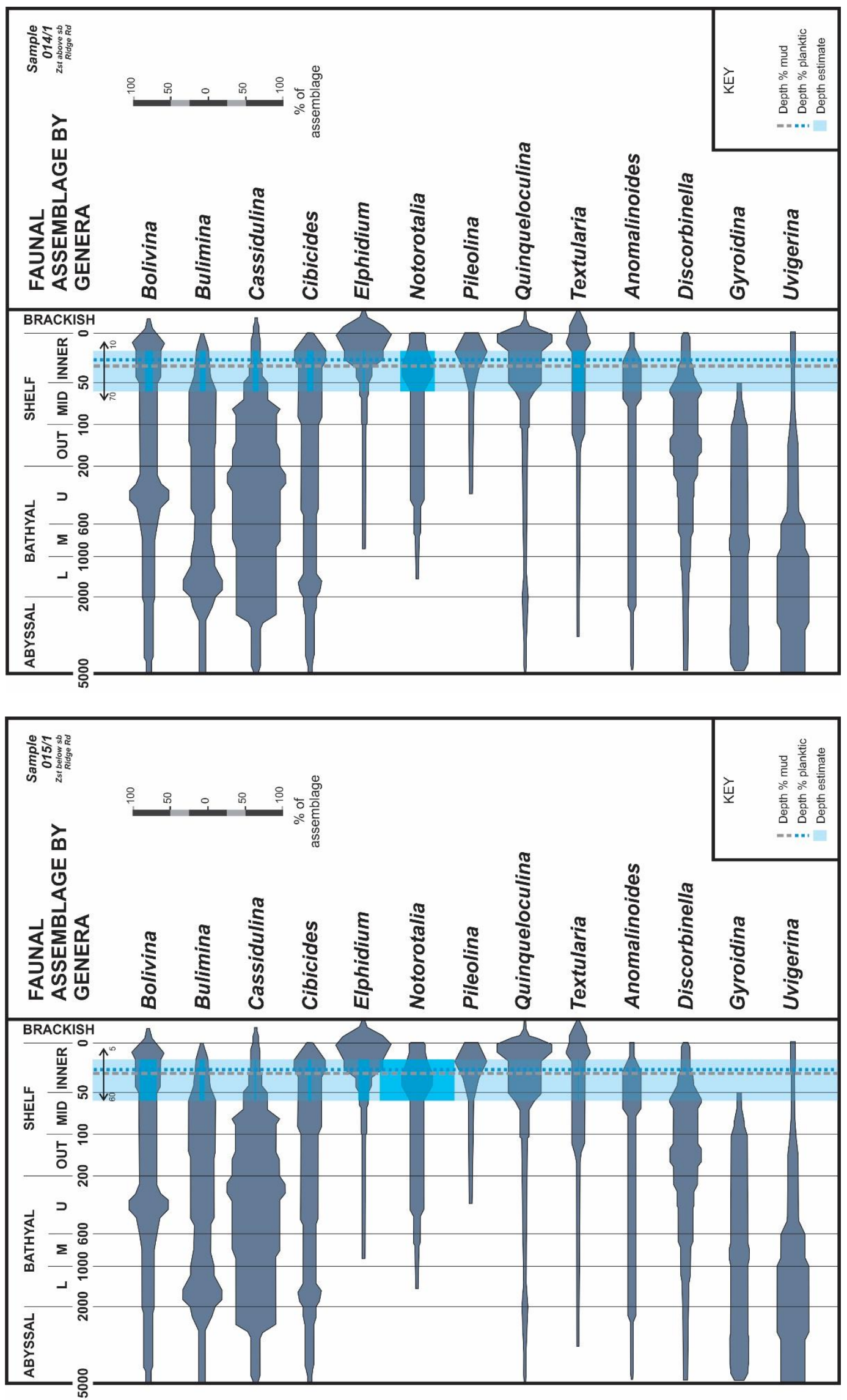


\section{A.7 MEASURED SECTIONS}

Measured sections are compiled here for four of the five sites visited in this study. The three sites of importance in the central Whanganui Basin are examined at 15 $\mathrm{cm}$ increments which have been placed in faunal and taphonomic clusters. Clusters have been group into subunits using the facies scheme of Figure 3.4.1 and other abbreviations used are shown in Tables A.7.2A and A.7.2B.

Table A.7.1: Summary of measured sections in enclosures.

\begin{tabular}{|c|c|c|c|c|}
\hline Enclosure & Site location & Section & \# pages & Measured thickness \\
\hline \multirow{2}{*}{1} & $\begin{array}{c}\text { Ridge Road, } \\
\text { Mangamahu }\end{array}$ & $\mathrm{A}$ & 1 & $1.65 \mathrm{~m}$ \\
\cline { 3 - 5 } 2 & $\mathrm{~B}$ & 1 & $2.90 \mathrm{~m}$ \\
\hline \multirow{2}{*}{3} & $\begin{array}{c}\text { Otiwhiti Station, Old } \\
\text { Hautawa Road, lower } \\
\text { Hautawa Stream }\end{array}$ & $\mathrm{A}$ & 2 & $6.40 \mathrm{~m}$ \\
\hline 4 & $\begin{array}{c}\text { West Road, } \\
\text { upper Hautawa Stream }\end{array}$ & $\mathrm{A}$ & 1 & $3.25 \mathrm{~m}$ \\
\cline { 3 - 5 } & $\begin{array}{c}\text { Colenso Station, } \\
\text { east of Taihape }\end{array}$ & $\mathrm{A}$ & 2 & $2.65 \mathrm{~m}$ \\
\hline
\end{tabular}

Table 17.2: Summary of facies abbreviations used in measured sections

\begin{tabular}{|c|c|c|}
\hline Abbreviation & Meaning & Matrix \\
\hline$S 1 a_{n f}$ & Non-fossiliferous; Sst & \multirow{9}{*}{ 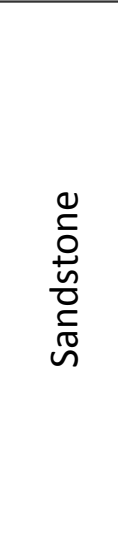 } \\
\hline$S 1 b_{n f}$ & Non-fossiliferous; fine Sst & \\
\hline$S 1 c_{n f}$ & Non-fossiliferous; very fine Sst & \\
\hline$S 2 a_{\text {bur }}$ & Burrowed; Sst & \\
\hline$S 2 b_{\text {bur }}$ & Burrowed; fine Sst & \\
\hline$S 2 c_{\text {bur }}$ & Burrowed; very fine Sst & \\
\hline$S 3 a_{\text {rare }}$ & Rare shell hash; Sst & \\
\hline$S 3 b_{\text {rare }}$ & Rare shell hash; fine Sst & \\
\hline$S 3 c_{\text {rare }}$ & Rare shell hash; very fine Sst & \\
\hline
\end{tabular}

\begin{tabular}{|c|c|c|}
\hline Abbreviation & Meaning & Matrix \\
\hline$Z 1_{n f}$ & Non-fossiliferous; Zst & \multirow{5}{*}{ 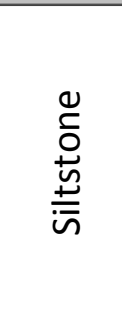 } \\
\hline$Z 2_{\text {bur }}$ & Burrowed; Zst & \\
\hline$Z 3_{\text {rare }}$ & Rare shell hash; Zst & \\
\hline$Z 4 a_{M}$ & Densely packed bed; various & \\
\hline$Z 4 b_{O}$ & Densely packed bed; Ostrea & \\
\hline
\end{tabular}

